Prepared in cooperation with the Eugene Water \& Electric Board and The Nature Conservancy

\title{
Development of an Environmental Flow Framework for the McKenzie River Basin, Oregon
}

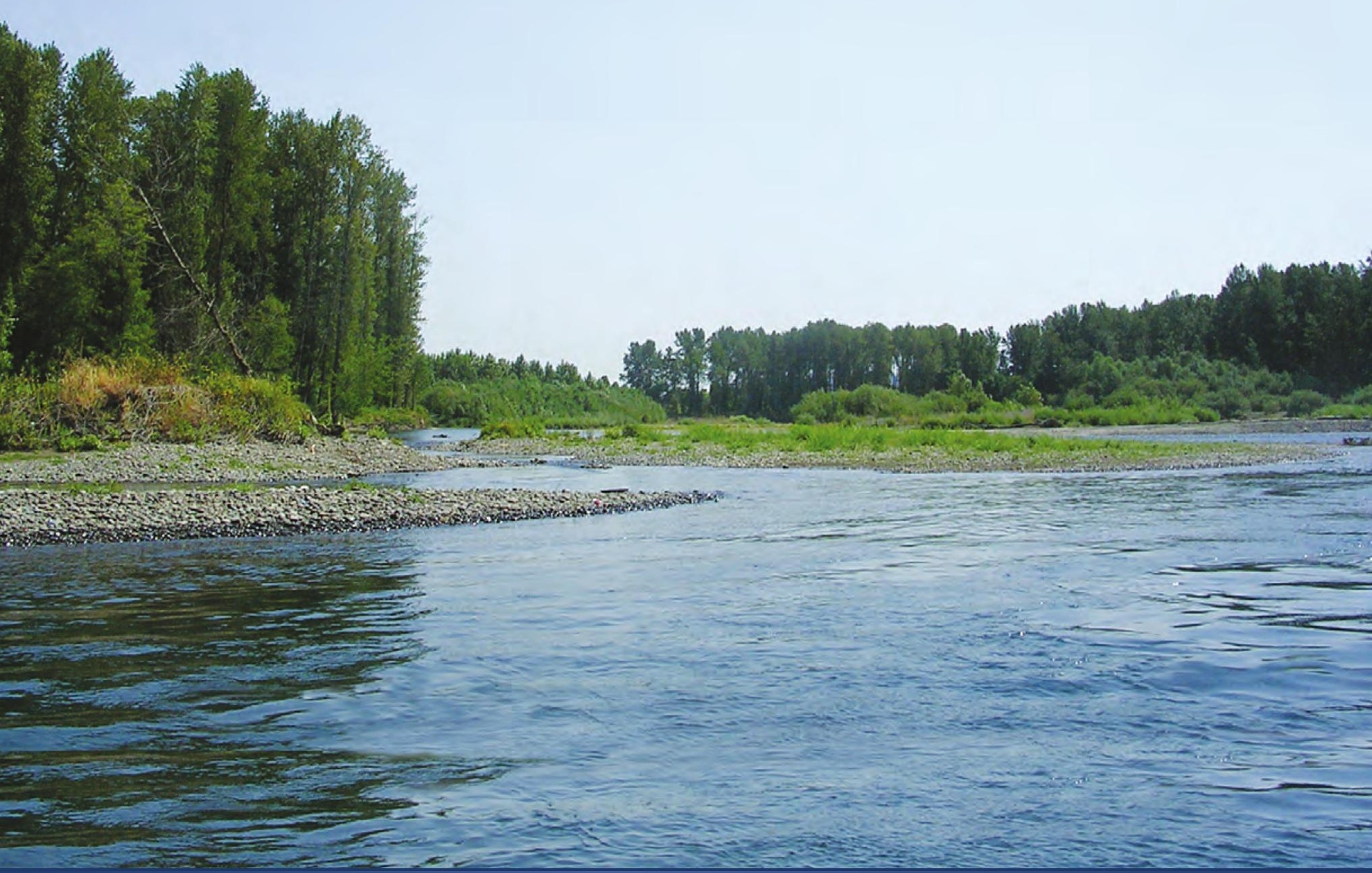

Scientific Investigations Report 2010-5016 
Cover: Lower McKenzie River near Springfield, Oregon. Photograph taken by John Risley, U.S. Geological Survey, July 2008. 


\section{Development of an Environmental Flow Framework for the McKenzie River Basin, Oregon}

By John Risley, J. Rose Wallick, Ian Waite, and Adam Stonewall

Prepared in cooperation with the Eugene Water \& Electric Board and The Nature Conservancy

Scientific Investigations Report 2010-5016 


\title{
U.S. Department of the Interior \\ KEN SALAZAR, Secretary \\ U.S. Geological Survey \\ Marcia K. McNutt, Director
}

\section{U.S. Geological Survey, Reston, Virginia: 2010}

\begin{abstract}
For more information on the USGS - the Federal source for science about the Earth, its natural and living resources, natural hazards, and the environment, visit http://www.usgs.gov or call 1-888-ASK-USGS

For an overview of USGS information products, including maps, imagery, and publications, visit http://www.usgs.gov/pubprod

To order this and other USGS information products, visit http://store.usgs.gov
\end{abstract}

Any use of trade, product, or firm names is for descriptive purposes only and does not imply endorsement by the U.S. Government.

Although this report is in the public domain, permission must be secured from the individual copyright owners to reproduce any copyrighted materials contained within this report.

Suggested citation:

Risley, John, Wallick, J.R., Waite, lan, and Stonewall, Adam, 2010, Development of an environmental flow framework for the McKenzie River basin, Oregon: U.S. Geological Survey Scientific Investigations Report 2010-5016, 94 p. 


\section{Contents}

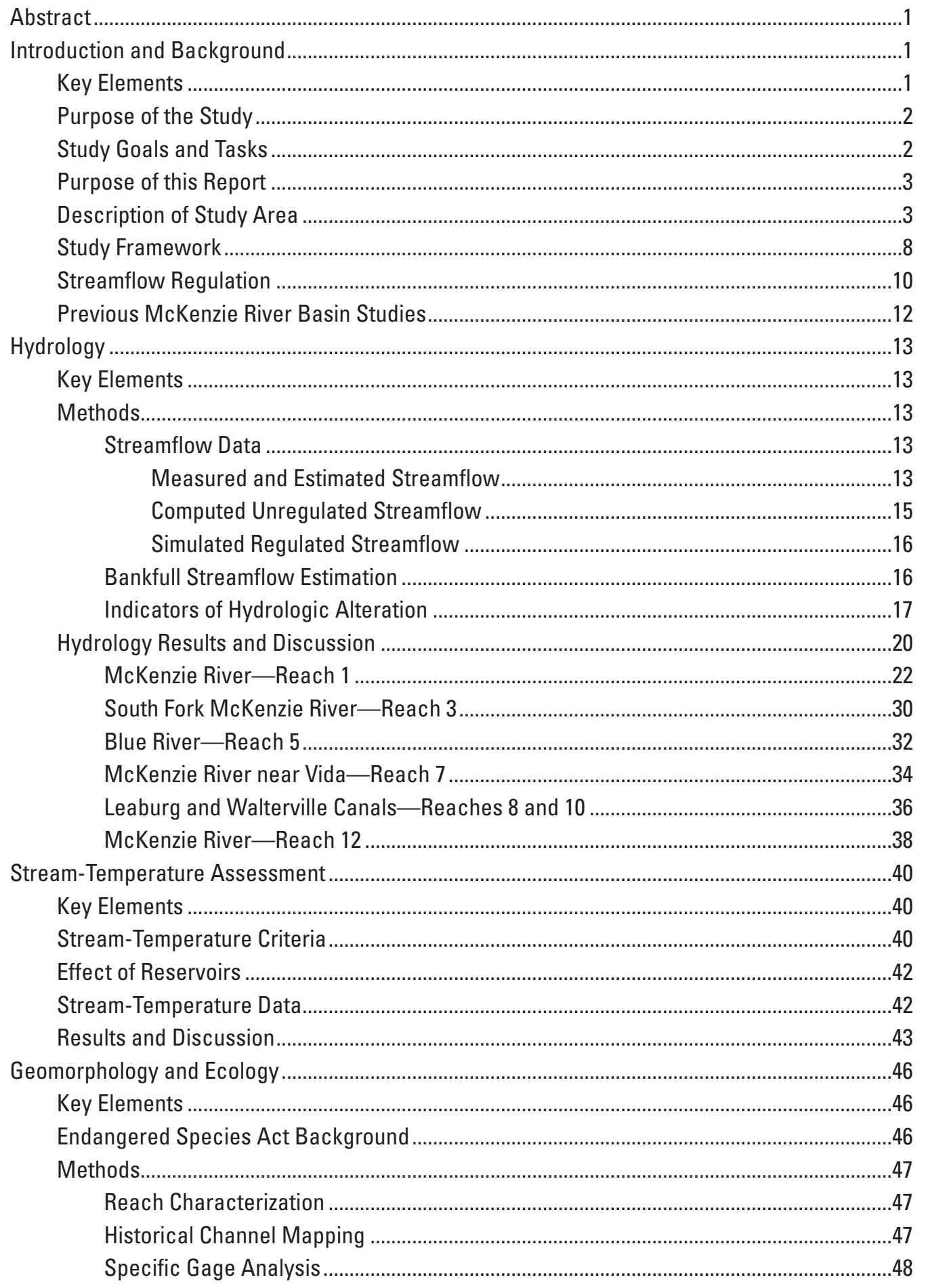




\section{Contents-Continued}

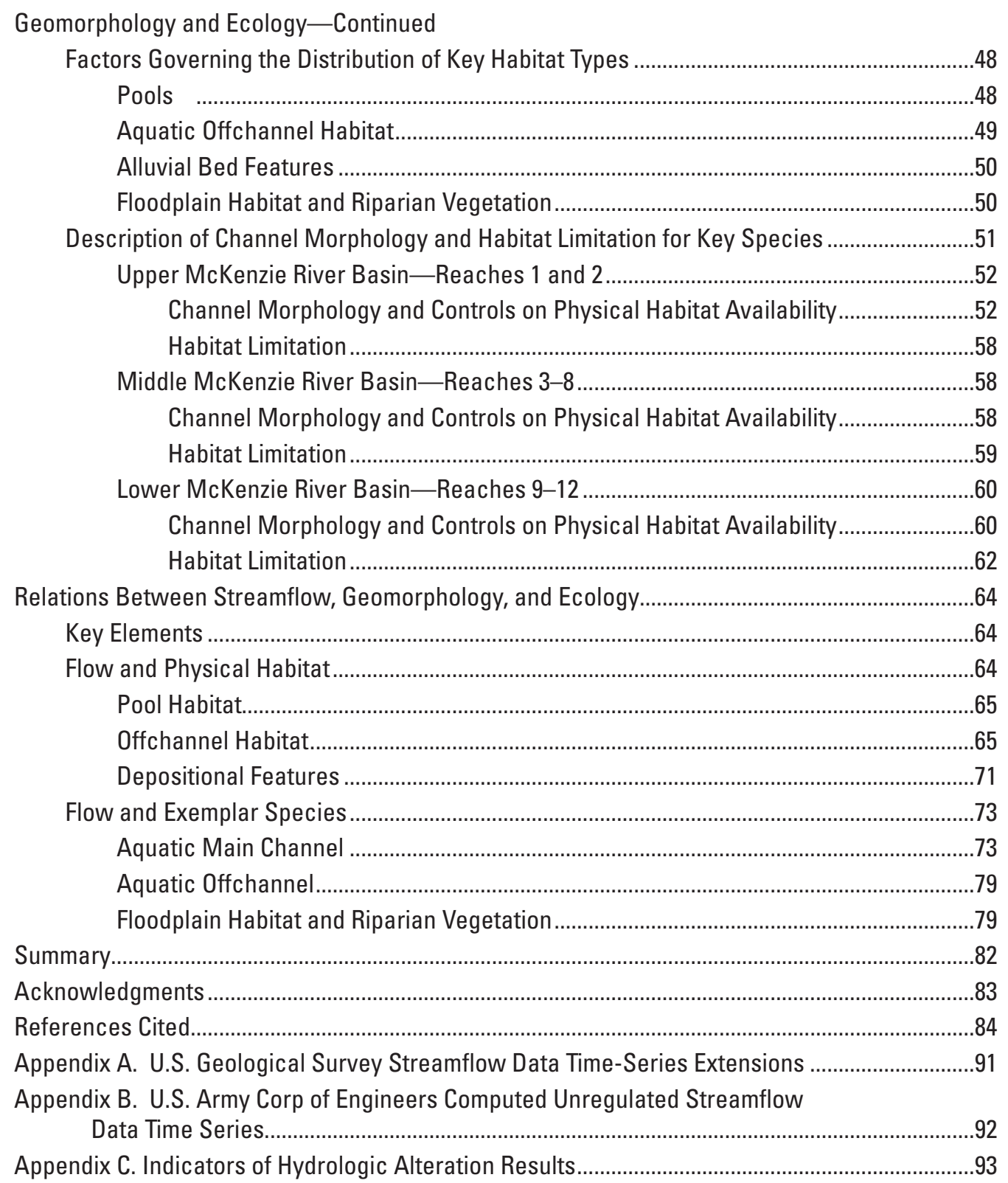




\section{Figures}

Figure 1. Map showing major tributaries and dams of the McKenzie River basin,

Oregon

Figure 2. Longitudinal profile of the McKenzie River showing reaches and basins,

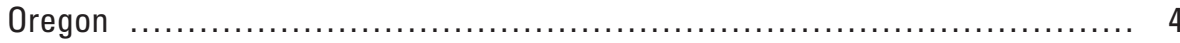

Figure 3. Map showing geology of the McKenzie River basin, Oregon $\quad \ldots \ldots \ldots \ldots \ldots \ldots \ldots \ldots$

Figure 4. Graph showing mean monthly precipitation, McKenzie River basin,

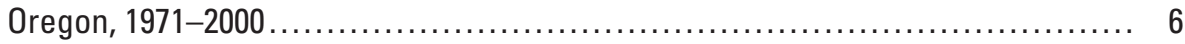

Figure 5. Map showing location of study reaches, McKenzie River, Oregon $\ldots \ldots \ldots \ldots \ldots \ldots . \quad 9$

Figure 6. Schematic diagram showing dams, canal diversions, streamflow-gaging and stream-temperature stations in the McKenzie River basin, Oregon .......... 11

Figure 7. Graph showing daily mean streamflow in Reach 7 at McKenzie River near Vida, Oregon (14162500), water years 1925-2008 ........................... 21

Figure 8. Graph showing mean daily streamflow in Reach 1 at McKenzie River below Trail Bridge Dam, near Belknap Springs, Oregon (14158850), water years

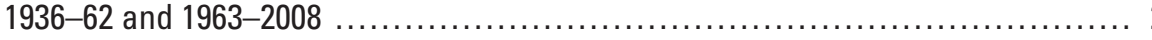

Figure 9. Graph showing daily mean streamflow in Reach 1 at McKenzie River below Trail Bridge Dam, near Belknap Springs, Oregon (14158850),

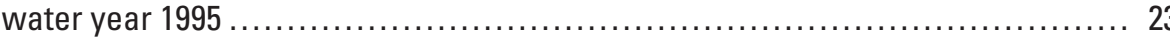

Figure 10. Graph showing mean daily streamflow in Reach 3 below Cougar Dam at South Fork McKenzie River, near Rainbow, Oregon (14159500) ............... 30

Figure 11. Graph showing daily mean streamflow in Reach 3 below Cougar Dam at South Fork McKenzie River, near Rainbow, Oregon (14159500), water year 1995

Figure 12. Graph showing mean daily streamflow in Reach 5 below Blue River Dam at Blue River, near Blue River, Oregon (14162000 and 14162200)

Figure 13. Graph showing daily mean streamflow in Reach 5 below Blue River Dam at Blue River, near Blue River, Oregon (14162200), water year 1995

Figure 14. Hydrograph showing mean daily streamflow in Reach 7 at McKenzie River near Vida, Oregon (14162500)

Figure 15. Hydrograph showing daily mean streamflow in Reach 7 at McKenzie River near Vida, Oregon (14162500), water year 1995

Figure 16. Hydrograph showing mean daily streamflow in Reach 8 at McKenzie River below Leaburg Dam, near Leaburg, Oregon (14163150) and Leaburg Canal ........ 36

Figure 17. Hydrograph showing mean daily streamflow in Reach 10 at McKenzie River near Walterville, Oregon (14163900) and Walterville Canal.

Figure 18. Hydrograph showing mean daily streamflow in Reach 12 at McKenzie River near Coburg, Oregon (14165500)

Figure 19. Hydrograph showing daily mean streamflow in Reach 12 at McKenzie River near Coburg, Oregon (14165500), water year 1995.

Figure 20. Graph showing mean daily maximum stream temperatures in the upper McKenzie River basin (Reach 1), Oregon

Figure 21. Graph showing mMean daily maximum stream temperatures in the South Fork McKenzie River (Reach 3), Oregon

Figure 22. Graph showing mean daily maximum stream temperatures in Blue River (Reach 5), Oregon 


\section{Figures-Continued}

Figure 23. Graph showing post-dam period mean daily maximum stream temperatures at monitoring stations on the McKenzie, South Fork McKenzie, and Blue Rivers,

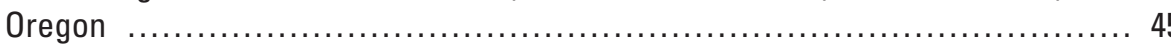

Figure 24. Graph showing study reach channel changes for 1939 and 2005, McKenzie

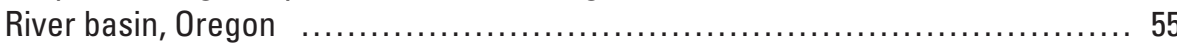

Figure 25. Graphs showing specific gage analyses for selected study reaches,

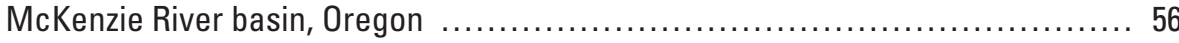

Figure 26. Aerial photographs of channel changes at selected sites for upper, middle, and lower McKenzie River basin, Oregon, 1939 and 2005

Figure 27. Map showing constraints on channel change for the lower McKenzie River basin, Oregon

Figure 28. Aerial photographs of changes in flood-plain vegetation in the lower and middle McKenzie River basins, Oregon, 1939 and 2005

Figure 29. Hydrograph showing pool processes in relation to observed regulated and computed unregulated daily mean streamflow at the McKenzie River near Vida, Oregon (14162500), water year 1995

Figure 30. Hydrograph showing offchannel processes in relation to observed regulated and computed unregulated daily mean streamflow at the McKenzie River near Vida, Oregon (14162500), water year 1995

Figure 31. Hydrograph showing observed and computed unregulated daily mean streamflow in Reach 7 at McKenzie River near Vida, Oregon (14162500), water years 1925-2008

Figure 32. Hydrograph showing depositional processes in relation to observed regulated and computed unregulated daily mean streamflow at the McKenzie River near Vida, Oregon, (14162500), water year 1995

Figure 33. Graphs showing life history of two native aquatic species, one anadromous (Chinook salmon) and one resident (bull trout), in relation to pre- and post-dam mean monthly streamflow at McKenzie River near Vida, Oregon (14162500)

Figure 34. Graphs showing life history of two resident native aquatic species, Oregon chub and Pacific lamprey, in relation to pre- and post-dam mean monthly streamflow at McKenzie River near Vida, Oregon (14162500)

Figure 35. Graphs showing life history of two resident native offchannel species, western pond turtle and red-legged frog, in relation to pre- and post-dam mean monthly streamflow at McKenzie River near Vida, Oregon (14162500)

Figure 36. Graphs showing life history of two native riparian vegetation species, black cottonwood and white alder, in relation to pre- and post-dam mean monthly streamflow at McKenzie River near Vida, Oregon (14162500) 


\section{Tables}

Table 1. Mean streamflow and basin yield at selected streamflow-gaging stations in the McKenzie River basin, Oregon

Table 2. Locations of study reaches in the McKenzie River basin, Oregon............... 8

Table 3. Dams in the McKenzie River basin, Oregon ............................. 10

Table 4. Minimum and maximum streamflow objectives below Blue River and Cougar Dams, McKenzie River, Oregon

Table 5. U.S. Geological Survey streamflow-gaging stations in the McKenzie River basin, Oregon

Table 6. Streamflow-gaging stations or streamflow points of the study reach, McKenzie

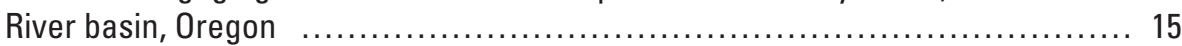

Table 7. Estimated bankfull gage heights and streamflows at study reach streamflow sites, McKenzie River basin, Oregon ................................... 16

Table 8. Indicators of Hydrologic Alteration parameters used to quantify hydrologic changes resulting from dams and canals, McKenzie River, Oregon .............. 18

Table 9. Environmental flow component parameters from the Indicators of Hydrologic Alteration software package and their ecosystem influences

Table 10. Significant changes to environmental flow components in the McKenzie River basin as a result of upstream dams

Table 11. Airport median monthly precipitation totals, Eugene, Oregon, 1936-1962 and

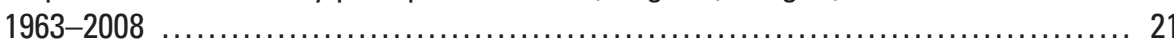

Table 12. Pre- and post-dam flood statistics for McKenzie River, Oregon $\ldots \ldots \ldots \ldots \ldots \ldots . . \ldots 23$

Table 13. Pre- and post-dam streamflow statistics from measured and estimated daily

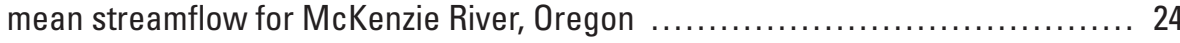

Table 14. Median monthly streamflows for pre-dam, post-dam, computed unregulated, and simulated regulated conditions in reaches, McKenzie River, Oregon $\ldots \ldots . .26$

Table 15. Hydrologic changes in selected reaches, McKenzie River, Oregon ............... 28

Table 16. Temperature criteria for Federal Clean Water Act section 303(d) listed

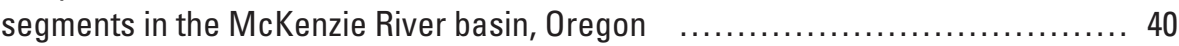

Table 17. Monthly streamflow-release target temperatures for Cougar and Blue River Dams, McKenzie River basin, Oregon

Table 18. Water temperature criteria for listed and sensitive fish species in the McKenzie River basin, Oregon

Table 19. U.S. Geological Survey stream-temperature monitoring sites in the McKenzie

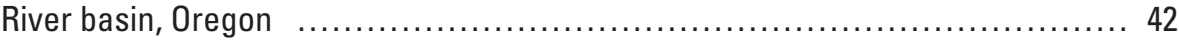

Table 20. Geomorphic characteristics of reaches in the McKenzie River basin, Oregon ..... 53

Table 21. Streamflow and physical habitat relationship summary for the upper, middle,

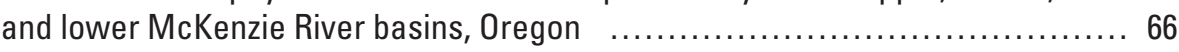

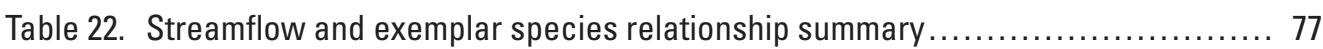




\section{Conversion Factors, Datums, and Acronyms and Abbreviations}

Conversion Factors

\begin{tabular}{|c|c|c|}
\hline Multiply & By & To obtain \\
\hline \multicolumn{3}{|c|}{ Length } \\
\hline inch (in.) & 25.4 & millimeter (mm) \\
\hline foot $(\mathrm{ft})$ & 0.3048 & meter $(\mathrm{m})$ \\
\hline mile (mi) & 1.609 & kilometer (km) \\
\hline \multicolumn{3}{|c|}{ Area } \\
\hline acre & 0.004047 & square kilometer $\left(\mathrm{km}^{2}\right)$ \\
\hline square mile $\left(\mathrm{mi}^{2}\right)$ & 2.590 & square kilometer $\left(\mathrm{km}^{2}\right)$ \\
\hline square yard $\left(\mathrm{yd}^{2}\right)$ & 0.8361 & square meter $\left(\mathrm{m}^{2}\right)$ \\
\hline \multicolumn{3}{|c|}{ Volume } \\
\hline cubic foot $\left(\mathrm{ft}^{3}\right)$ & 0.02832 & cubic meter $\left(\mathrm{m}^{3}\right)$ \\
\hline acre-foot (acre-ft) & 1,233 & cubic meter $\left(\mathrm{m}^{3}\right)$ \\
\hline \multicolumn{3}{|c|}{ Flow rate } \\
\hline cubic foot per second (ft $\left.\mathrm{ft}^{3} \mathrm{~s}\right)$ & 0.02832 & cubic meter per second $\left(\mathrm{m}^{3} / \mathrm{s}\right)$ \\
\hline $\begin{array}{l}\text { cubic foot per second per square } \\
\text { mile }\left[\left(\mathrm{ft}^{3} / \mathrm{s}\right) / \mathrm{mi}^{2}\right]\end{array}$ & 0.01093 & $\begin{array}{l}\text { cubic meter per second per } \\
\text { square kilometer }\left[\left(\mathrm{m}^{3} / \mathrm{s}\right) / \mathrm{km}^{2}\right]\end{array}$ \\
\hline \multicolumn{3}{|c|}{ Energy } \\
\hline kilowatthour (kWh) & $3,600,000$ & joule $(\mathrm{J})$ \\
\hline
\end{tabular}

Temperature in degrees Celsius $\left({ }^{\circ} \mathrm{C}\right)$ may be converted to degrees Fahrenheit $\left({ }^{\circ} \mathrm{F}\right)$ as follows:

$$
{ }^{\circ} \mathrm{F}=\left(1.8 x^{\circ} \mathrm{C}\right)+32 .
$$

*Transmissivity: The standard unit for transmissivity is cubic foot per day per square foot times foot of aquifer thickness [(ft $\left.\left.\mathrm{ft}^{3} \mathrm{~d}\right) / \mathrm{ft}^{2}\right] \mathrm{ft}$. In this report, the mathematically reduced form, foot squared per day $\left(\mathrm{ft}^{2} / \mathrm{d}\right)$, is used for convenience.

Datums

Vertical coordinate information is referenced to the North American Vertical Datum of 1988 (NAVD 88).

Horizontal coordinate information is referenced to the North American Datum of 1983 (NAD 83).

Elevation, as used in this report, refers to distance above the vertical datum. 


\title{
Conversion Factors, Datums, and Acronyms and Abbreviations-Continued
}

\author{
Acronyms and Abbreviations \\ BA biological assessment \\ BLM Bureau of Land Management \\ EWEB Eugene Water and Electric Board \\ EFC Environmental Flow Component \\ ESA Endangered Species Act \\ FERC Federal Energy Regulatory Commission \\ GLO General Land Office \\ HEC Hydrologic Engineering Center \\ IHA Indicators of Hydrologic Alteration \\ LTER Long-Term Ecological Research \\ NMFS National Marine Fisheries Service \\ ODEO Oregon Department of Environmental Quality \\ SRP Sustainable Rivers Project \\ TMDL Total Maximum Daily Load \\ TNC The Nature Conservancy \\ USACE U.S. Army Corps of Engineers \\ USFS U.S. Forest Service \\ USFWS U.S. Fish and Wildlife Service \\ USGS U.S. Geological Survey \\ WTC water temperature control \\ WY water year
}


This page intentionally left blank. 


\title{
Development of an Environmental Flow Framework for the McKenzie River Basin, Oregon
}

\author{
By John Risley, J. Rose Wallick, Ian Waite, and Adam Stonewall
}

\section{Abstract}

The McKenzie River is a tributary to the Willamette River in northwestern Oregon. The McKenzie River is approximately 90 miles in length and has a drainage area of approximately 1,300 square miles. Two major flood control dams, a hydropower dam complex, and two hydropower canals significantly alter streamflows in the river. The structures reduce the magnitude and frequency of large and small floods while increasing the annual 7-day minimum streamflows. Stream temperatures also have been altered by the dams and other anthropogenic factors, such as the removal of riparian vegetation and channel simplification. Flow releases from one of the flood control dams are cooler in the summer and warmer in the fall in comparison to unregulated flow conditions before the dam was constructed. In 2006, the Oregon Department of Environmental Quality listed a total of 112.4, 6.3, and 55.7 miles of the McKenzie River basin mainstem and tributary stream reaches as thermally impaired for salmonid rearing, salmonid spawning, and bull trout, respectively.

The analyses in this report, along with previous studies, indicate that dams have altered downstream channel morphology and ecologic communities. In addition to reducing the magnitude and frequency of floods, dams have diminished sediment transport by trapping bed material. Other anthropogenic factors, such as bank stabilization, highway construction, and reductions of in-channel wood, also have contributed to the loss of riparian habitat. A comparison of aerial photography taken in 1939 and 2005 showed substantial decreases in secondary channels, gravel bars, and channel sinuosity, particularly along the lower alluvial reaches of the McKenzie River. In addition, bed armoring and incision may contribute to habitat degradation, although further study is needed to determine the extent of these processes. Peak streamflow reduction has led to vegetation colonization and stabilization of formerly active bar surfaces. The large flood control dams on Blue River and South Fork McKenzie River likely have had the greatest effect on downstream habitats because these sediment and flood-rich tributaries historically contributed a disproportionate volume of bed material, wood, and peak flows in comparison with the spring-fed tributaries of the upper McKenzie River basin.

The ecological effects of the dams were examined by focusing on nine exemplar aquatic and terrestrial species, including spring Chinook salmon, bull trout, Oregon chub, Pacific and western brook lamprey, red-legged frog, western pond turtle, alder, and cottonwood. The changes caused by the dams to streamflow hydrograph affect all these and other species in complex ways, although a few commonalities are apparent. A loss of channel complexity in the McKenzie River basin, which is associated with the reduction in flood events and widespread channel stabilization, is the primary factor related to the observed population declines for all nine exemplar species. The dams also have caused direct ecological effects by blocking access to habitat, changing the amount and timing of available critical habitat, and changing water temperature during important seasons for different life stages.

\section{Introduction and Background}

\section{Key Elements}

- This report presents the results of a study that is part of the Nature Conservancy Sustainable Rivers Project begun in 2002 in partnership with U.S. Army Corps of Engineers.

- The study objective was the creation of an environmental flow framework for the McKenzie River basin, Oregon, necessary to sustain aquatic and terrestrial ecosystems.

- The goal of this report is to provide a hydrologic, geomorphic, and ecological baseline assessment for basin stakeholders.

- The McKenzie River is approximately $90 \mathrm{mi}$ in length and has a drainage area of approximately 1,300 $\mathrm{mi}^{2}$. 
- The study area was divided into three basins with 12 reaches extending from Trail Bridge Dam to the Willamette River confluence. The upper McKenzie River basin (Reaches 1 and 2) extends from Trail Bridge Dam to the South Fork McKenzie River confluence. The middle McKenzie River basin (Reaches 3 through 8), including the South Fork McKenzie River downstream of Cougar Dam, extends from the South Fork McKenzie River confluence to Leaburg, Oregon. The lower McKenzie River basin (Reaches 9 through 12) extends from Leaburg to the Willamette River confluence.

- Streamflows in the upper basin are fed by highly productive springs. The middle basin is situated in the rugged and highly dissected Western Cascades, where the hydrology is controlled by less-permeable geology, snowmelt, and rain-on-snow events. In the lower basin, downstream of Leaburg, the river flows through a generally unconstrained floodplain to its confluence with the Willamette River.

- The McKenzie River is regulated by the Carmen-SmithTrail Bridge hydropower dam complex, Cougar and Blue River flood control dams, and the Leaburg and Walterville hydropower canals.

\section{Purpose of the Study}

The McKenzie River environmental flow study is a collaborative effort of The Nature Conservancy (TNC), the Eugene Water \& Electric Board (EWEB), The U.S. Army Corps of Engineers (USACE), and the U.S. Geological Survey (USGS) to develop environmental flow requirements for the McKenzie River basin. In 2002, TNC and the USACE formed the Sustainable Rivers Project (SRP), a partnership aimed at developing, implementing, and refining environmental flow requirements downstream of dams. Environmental flows can be defined as the streamflow needed to sustain ecosystems while continuing to meet human needs. Developing environmental flow requirements typically involves a collective process of interested and involved stakeholders to identify and prioritize streamflow objectives. The process often is a series of steps and feedback loops that include defining the streamflow requirements, implementing them into the dam operations, monitoring and modeling the streamflow changes and their effect on the river ecosystem, and then adjusting and refining the streamflow requirements if necessary. In addition to dams, other anthropogenic factors in a watershed contribute to freshwater ecosystem degradation, such as water diversions, channel revetment, timber harvest, wetland draining, invasive species, gravel extraction, and other factors, which are taken into consideration during the process (Tharme, 2003; Acreman and Dunbar, 2004; Richter and others, 2006; The Nature Conservancy (2009e).

Since the creation of the partnership, SRP projects have been implemented on a number of rivers around the Nation, including the Bill Williams River in Arizona (Shafroth and Beauchamp, 2006), the Savannah River between South Carolina and Georgia (The Nature Conservancy, 2009a), the Big Cypress Bayou in Texas, the White and Black Rivers in Arkansas, the Green River in Kentucky (The Nature Conservancy, 2009b), the Roanoke River in Virginia (The Nature Conservancy, 2009c), and the Willamette River (The Nature Conservancy, 2009d). Within the Willamette River basin, environmental flow guidelines have already been developed for the Coast and Middle Fork Willamette River basins (Gregory and others, 2007a, 2007b). Recommendations for new dam flow releases and ecological monitoring were made by Coast and Middle Fork Willamette River basin stakeholders who attended a workshop in January 2007. This McKenzie River basin environmental flow study is the second phase of the Willamette River Sustainable River Project. Eventually other Willamette River subbasins, such as the Santiam, also will undergo an environmental flow development process.

\section{Study Goals and Tasks}

The goal of this study was the creation of an environmental flow framework for the McKenzie River basin that is based on a scientific assemblage of ecological, hydrologic, and geomorphologic baseline data. The assemblage will include an assessment of changes resulting from anthropogenic effects that have occurred in the basin. Tasks to achieve this goal include:

1. Conducting reconnaissance level hydrologic, geomorphic, and ecological assessments along the mainstem, and some tributaries, of the McKenzie River.

2. Assembling and synthesizing information necessary to enable managers and stakeholders to develop environmental flow recommendations for the system.

3. Developing a future data monitoring plan to evaluate the environmental flow guidelines. 


\section{Purpose of this Report}

This report will provide McKenzie River basin stakeholders with a compilation of relevant streamflow, geomorphic, and ecological data and analyses necessary for them to prescribe the rate, frequency, duration, and timing of flow releases from McKenzie River basin dams for various downstream locations.

\section{Description of Study Area}

The McKenzie River drains a 1,300 $\mathrm{mi}^{2}$ area in western Oregon (fig. 1). From the headwaters at Clear Lake in the Cascade Range the river traverses approximately $90 \mathrm{mi}$ before it joins the Willamette River near Eugene, Oregon.

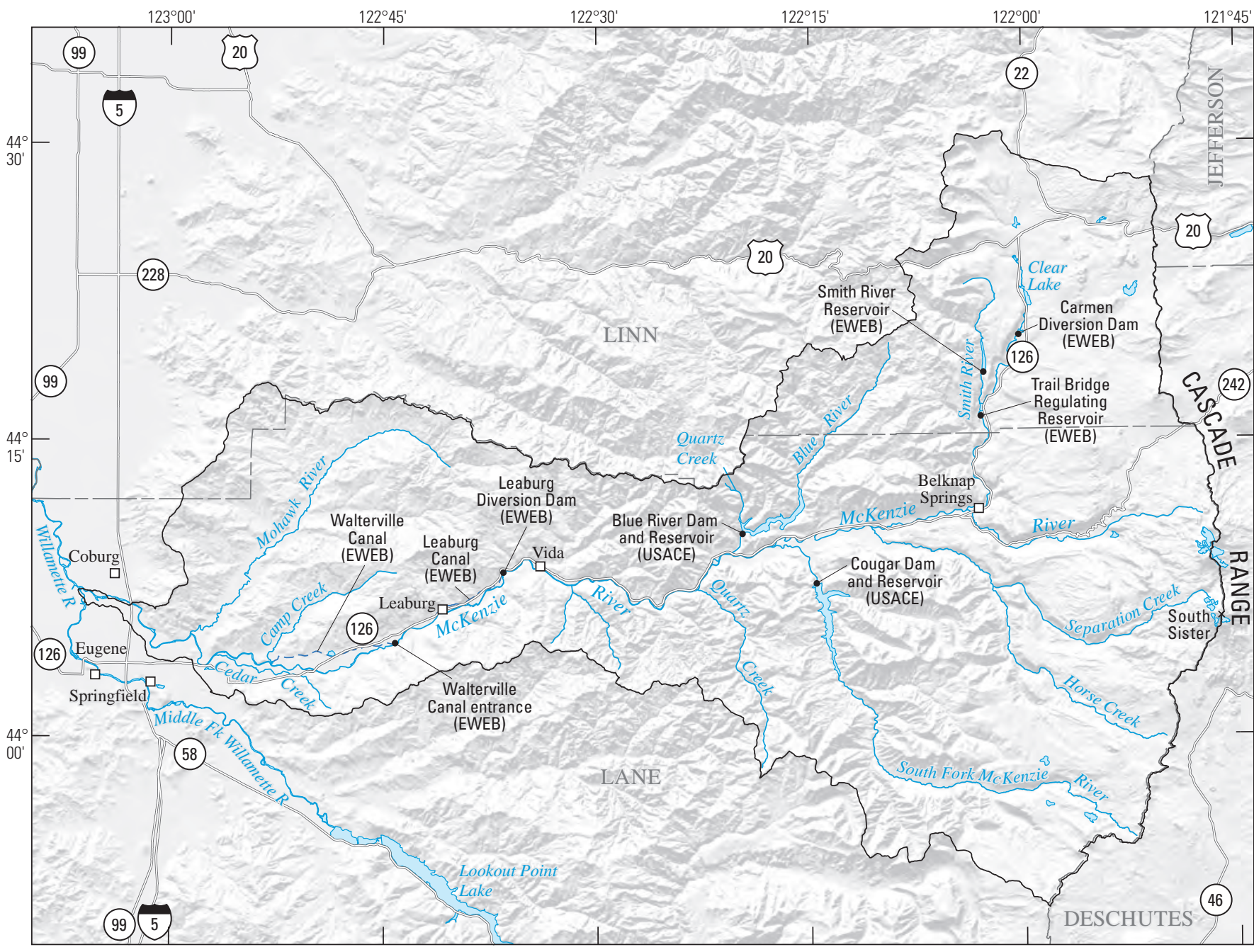

Base from Oregon Geospatial Enterprise digital data, various dates, 1:100,000. Universal Transverse Mercator Projection, Zone 10, North American Datum of 1983

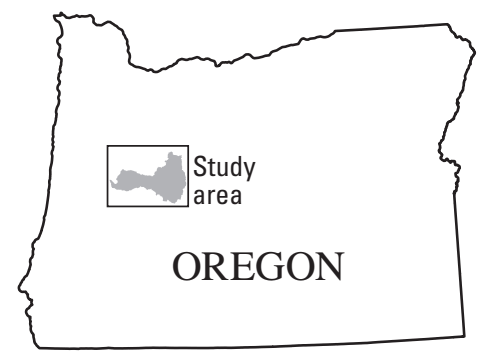

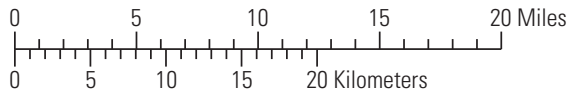

Note: EWEB = Eugene Water \& Electric Board USACE $=$ U.S. Army Corps of Engineers

Figure 1. Major tributaries and dams of the McKenzie River basin, Oregon. 
Elevations in the McKenzie River basin range from about $375 \mathrm{ft}$ at the Willamette River confluence to $10,358 \mathrm{ft}$ at the summit of South Sister. The river slope ranges from less than 0.2 percent in the wide, unconstrained floodplain in the Willamette Valley to greater than 1.2 percent upstream of Belknap Springs, Oregon, at river mile (RM) 75 (fig. 2). The upstream reaches of the McKenzie River, 24 percent of the basin, are fed by springs and snow melt in the High Cascades, a high elevation area underlain by young relatively permeable material consisting of High Cascade volcanic rocks and glacial deposits. The middle reaches flow through older volcanic material of the Western Cascades, a region of older less permeable weathered volcanic material representing
58 percent of the basin. Streams deeply dissect the Western Cascade area. In the lower reaches, the remaining 18 percent of the basin is Quaternary alluvium primarily along the valley bottoms (Sherrod and Smith, 2000) (fig. 3).

The climate of the McKenzie River basin is temperate marine characterized by dry summers and wet winters (fig. 4). About 90 percent of the normal precipitation falls between October and May. Mean annual precipitation ranges from about 40 in. in the Willamette Valley at Eugene to more than 125 in. at the crest of the Cascades. About 35 percent of the precipitation falls as snow at the 4,000-ft elevation, and more than 75 percent at the 7,000-ft elevation.

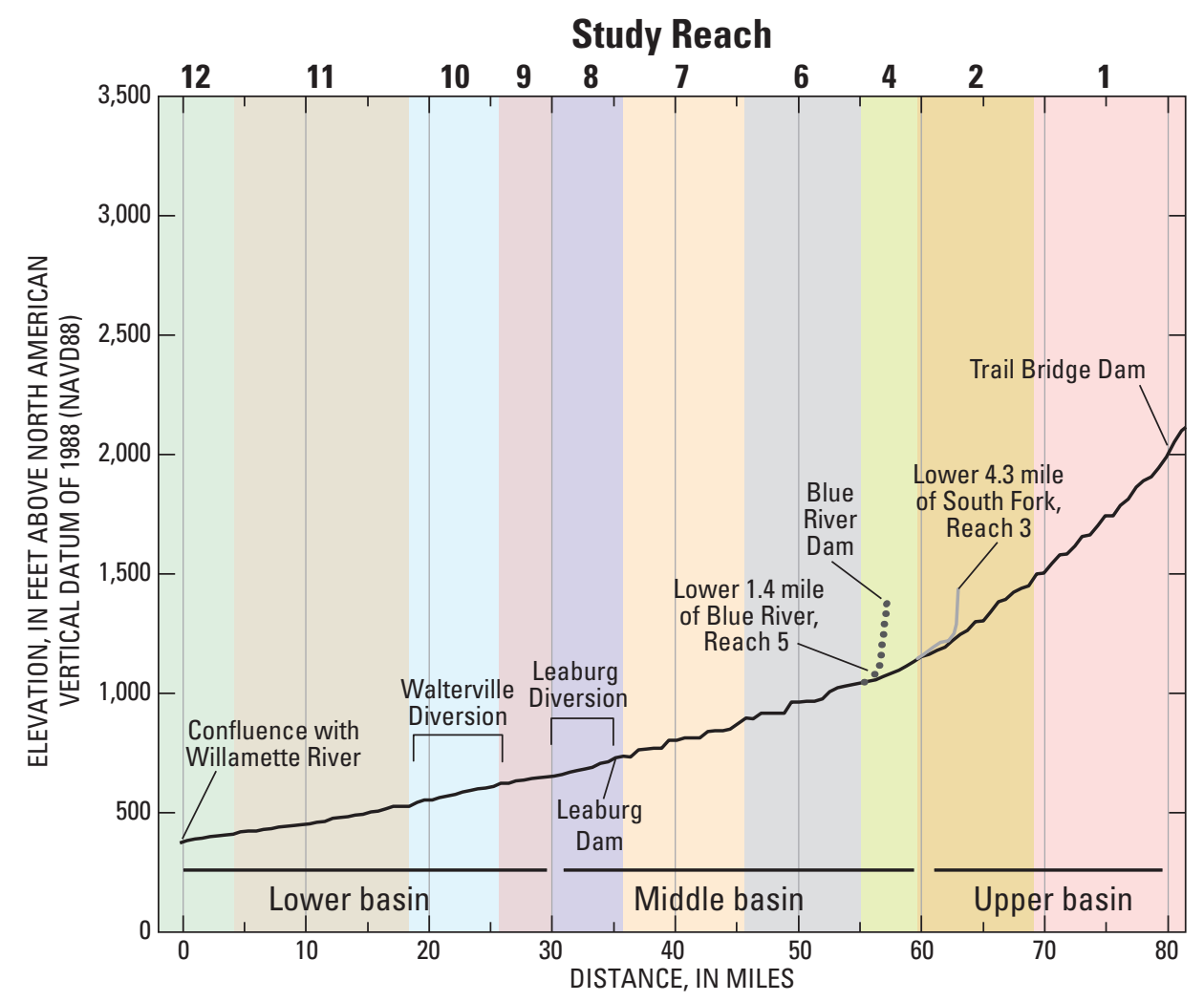

EXPLANATION

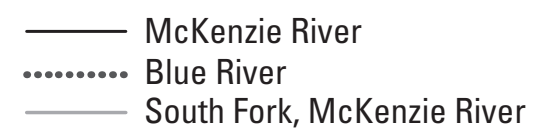

Figure 2. Longitudinal profile of the McKenzie River showing reaches and basins, Oregon. 


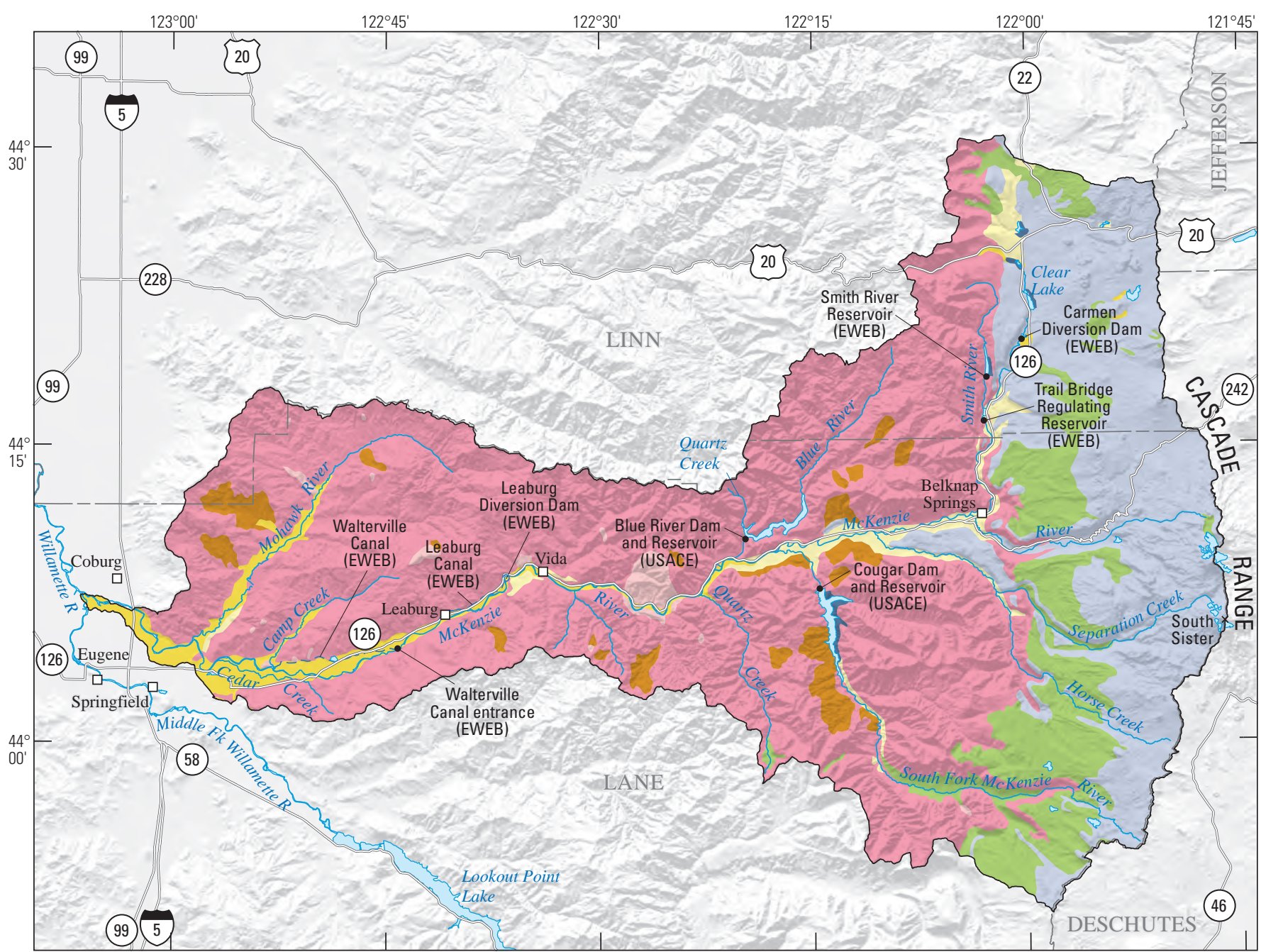

Base from Oregon Geospatial Enterprise digital data, various dates, 1:100,000. Universal Transverse Mercator Projection, Zone 10, North American Datum of 1983

\section{EXPLANATION}

\section{Geologic Units}

Undivided Quaternary sediment and sedimentary rocks

Quaternary alluvial deposits

Quaternary glacial deposits

Quaternary landslide deposits

Tertiary intrusive rocks

Western Cascades volcanic and volcaniclastic rocks

High Cascades volcanic rocks

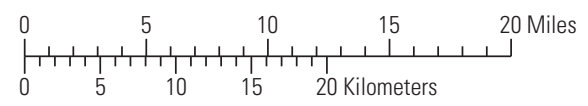

Geology modified from Sherrod and Smith (2000) and $\mathrm{O}^{\prime}$ Connor and others (2001)

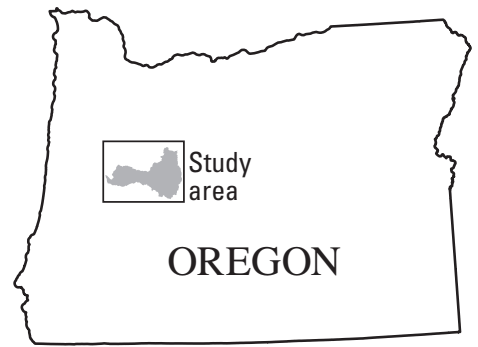

Figure 3. Geology of the McKenzie River basin, Oregon. 


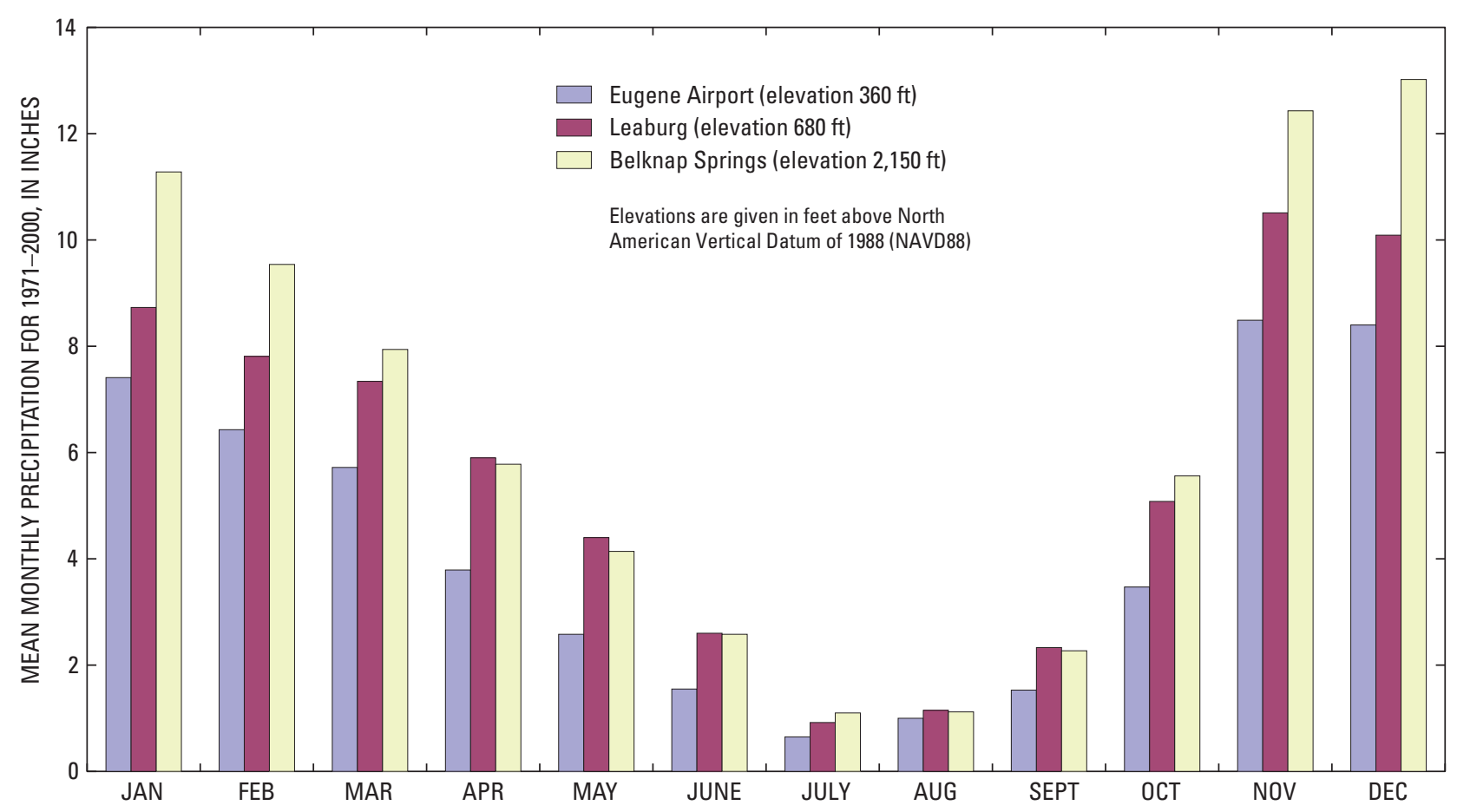

Figure 4. Mean monthly precipitation, McKenzie River basin, Oregon, 1971-2000.

Major tributaries in the upper McKenzie River basin include the Smith River, Horse Creek, the South Fork McKenzie River, and the Blue River. The terrain of the upper basin is mountainous, with steep ridges and narrow floodplains and terraces in the valleys along the streams. The hydrology is largely controlled by the basin geology. In the upper basin, precipitation infiltrates through porous volcanic High Cascades terrain and emerges from large spring complexes that support steady year-round discharge and cool stream temperatures in the mainstem McKenzie River. Additional discussion regarding the hydrogeology of Cascade volcanics and their relationship to McKenzie River basin spring-dominated streamflows and stream temperatures can be found in Stearns (1928), Ingrebritsen and others (1994), Manga (1997), Tague and Grant (2004), Jefferson and others (2006), and Tague and others (2007).
The middle and lower McKenzie River basin, downstream of the South Fork McKenzie River confluence (RM 60), is situated in the rugged and highly dissected Western Cascades, where the hydrology is controlled by geology, snowmelt, and rain-on-snow events. As a consequence of less-permeable geologic formations, streamflow in this region is more responsive to storm runoff than the upper basin, which results in high sediment yields (U.S. Forest Service, 1995; Stillwater Sciences, 2006b). Major tributaries include Quartz, Gate, and Martin Creeks and the Mohawk River. Between Blue River (RM 57) and the Leaburg Dam (RM 39), the channel is confined. Downstream of Leaburg, Oregon (RM 33), the river flows through a generally unconfined valley with a broad floodplain to its confluence with the Willamette River. 
Differences in basin yield between the upper and lower basins of the McKenzie River basin are evident in the streamflow data (table 1). Basin yield, computed by dividing mean streamflow by drainage area, generally is highest in the upper basins, such as above Trail Bridge Dam, Lookout Creek, and Blue River. Yield generally is lowest in the downstream basins, such as Cedar Creek and the Mohawk River. Although the yield at the McKenzie River near Coburg streamflow-gaging station is slightly higher than at the McKenzie River near Vida station, the Coburg streamflow record (1945-72) represents a wetter period. The Vida streamflow record for the same time period has a computed yield of $4.72\left(\mathrm{ft}^{3} / \mathrm{s}\right) / \mathrm{mi}^{2}$.
The McKenzie River basin supports timber harvesting, recreation, agriculture, and manufacturing. Most of the human population in the basin is near or within the Eugene and Springfield urban growth boundaries. The floodplain in the lower McKenzie River basin is mostly privately owned and used for agriculture. Overall, the Federal Government owns approximately 70 percent of land in the basin. The Bureau of Land Management (BLM) owns tracts in the Mohawk River subbasin and the middle parts of the McKenzie River basin. Above Quartz Creek (RM 54) the McKenzie River basin is almost entirely within the Willamette National Forest (Northwest Power and Conservation Council, 2004).

Table 1. Mean streamflow and basin yield at selected streamflow-gaging stations in the McKenzie River basin, Oregon.

[Period of record: A water year is from October 1 to September 30. Basin yield is computed as mean streamflow divided by drainage area. Abbreviations: $\mathrm{ft}^{3} / \mathrm{s}$, cubic feet per second; $\left(\mathrm{ft}^{3} / \mathrm{s}\right) / \mathrm{mi}^{2}$, cubic feet per second per square mile; $\mathrm{mi}^{2}$, square mile]

\begin{tabular}{|c|c|c|c|c|c|}
\hline $\begin{array}{c}\text { Station } \\
\text { No. }\end{array}$ & Streamflow-gaging station name & $\begin{array}{l}\text { Computation } \\
\text { period of record } \\
\text { (water years) }\end{array}$ & $\begin{array}{c}\text { Mean } \\
\text { streamflow } \\
\left(\mathrm{ft}^{3} / \mathrm{s}\right)\end{array}$ & $\begin{array}{l}\text { Drainage } \\
\text { area } \\
\left(\mathrm{mi}^{2}\right)\end{array}$ & $\begin{array}{c}\text { Basin } \\
\text { yield } \\
{\left[\left(\mathrm{ft}^{3} / \mathrm{s}\right) / \mathrm{mi}^{2}\right]}\end{array}$ \\
\hline 14158850 & McKenzie River below Trail Bridge Dam, near Belknap Springs & $1960-08$ & 1,010 & 184 & 5.49 \\
\hline 14159000 & McKenzie River at McKenzie Bridge & 1936-94 & 1,690 & 348 & 4.86 \\
\hline 14159500 & South Fork McKenzie River near Rainbow & $1948-08$ & 846 & 208 & 4.07 \\
\hline 14161500 & Lookout Creek near Blue River & $1949-55 ; 1963-08$ & 122 & 24.1 & 5.06 \\
\hline 14162200 & Blue River at Blue River & $1967-08$ & 456 & 87.7 & 5.20 \\
\hline 14162500 & McKenzie River near Vida & $1925-08$ & 4,039 & 930 & 4.34 \\
\hline 14163000 & Gate Creek at Vida & $1952-57 ; 1967-90$ & 209 & 47.6 & 4.40 \\
\hline 14164700 & Cedar Creek at Springfield & $2001-08$ & 31 & 9.62 & 3.21 \\
\hline 14165000 & Mohawk River near Springfield & $1935-52 ; 1998-08$ & 528 & 177 & 2.98 \\
\hline 14165500 & McKenzie River near Coburg & $1945-72$ & 5,916 & 1,337 & 4.43 \\
\hline
\end{tabular}




\section{Study Framework}

The study area was divided into three basins with 12 river reaches, each having distinct streamflow, geomorphic, and sediment input conditions (fig. 5; table 2). The upper McKenzie River basin (Reaches 1 and 2) extends from Trail Bridge Dam to the South Fork McKenzie River confluence; the middle McKenzie River basin (Reaches 3-8), including the South Fork McKenzie River downstream of Cougar Dam, extends from the South Fork McKenzie River confluence to Leaburg, Oregon; and the lower McKenzie River basin (Reaches 9-12) extends from Leaburg, Oregon to the Willamette River confluence. Ten of the 12 reaches are on the mainstem of the McKenzie River. The two tributary reaches include the South Fork McKenzie River downstream of Cougar Dam (Reach 3) and the Blue River from the Blue River Dam to the McKenzie River confluence (Reach 5).
Where the downstream end of a reach is near a major stream confluence, the downstream end of the reach is always defined as being located just upstream of the confluence. Streamflow from the confluent stream is included in the streamflow of the next downstream reach. This was done to minimize the difference in streamflow between both ends of the reach and to use a single representative reach discharge in the analyses. Two of the reaches (8 and 10) were between the diversion dam and return streamflow locations of the Walterville and Leaburg canals. Key study reaches that are emphasized in this report include Reach 1 (immediately downstream of Trail Bridge Dam), Reach 3 (immediately downstream of Cougar Dam), Reach 5 (immediately downstream of Blue River Dam), Reach 7 (includes a long-term streamflow-gaging station near Vida and is affected by the cumulative effects of upstream dams), and Reach 12 (affected by the cumulative effects of upstream dams and canal diversions).

Table 2. Locations of study reaches in the McKenzie River basin, Oregon.

[Location of study reaches shown in figure 5. Upstream end river mile: River mile from the Willamette River confluence. A designated river mile was used as a flow point if there was no streamflow-gaging station within the reach]

\begin{tabular}{|c|c|c|c|c|c|}
\hline $\begin{array}{c}\text { Reach } \\
\text { No. }\end{array}$ & River name & Upstream end description & $\begin{array}{l}\text { Upstream } \\
\text { end } \\
\text { river mile }\end{array}$ & Downstream end description & $\begin{array}{l}\text { Reach } \\
\text { length } \\
\text { (miles) }\end{array}$ \\
\hline 1 & McKenzie & Below Trail Bridge Dam & 81.8 & McKenzie Bridge & 13.7 \\
\hline 2 & McKenzie & McKenzie Bridge & 68.1 & South Fork McKenzie River confluence & 8.4 \\
\hline 3 & South Fork McKenzie & Below Cougar Dam & 4.5 & McKenzie River confluence & 4.5 \\
\hline 4 & McKenzie & South Fork McKenzie River confluence & 59.7 & Blue River confluence & 2.6 \\
\hline 5 & Blue & Below Blue River Dam & 1.5 & McKenzie River confluence & 1.5 \\
\hline 6 & McKenzie & Blue River confluence & 57.1 & Nimrod & 6.1 \\
\hline \multicolumn{6}{|c|}{ Lower basin } \\
\hline 9 & McKenzie & Leaburg canal return flow & 33.0 & Walterville canal entrance & 5.0 \\
\hline 10 & McKenzie & Walterville canal entrance & 28.0 & Camp Creek confluence & 7.3 \\
\hline 11 & McKenzie & Camp Creek confluence & 20.7 & Armitage State Park at I-5 bridge & 13.5 \\
\hline 12 & McKenzie & Armitage State Park at I- 5 bridge & 7.2 & Willamette River confluence & 7.2 \\
\hline
\end{tabular}




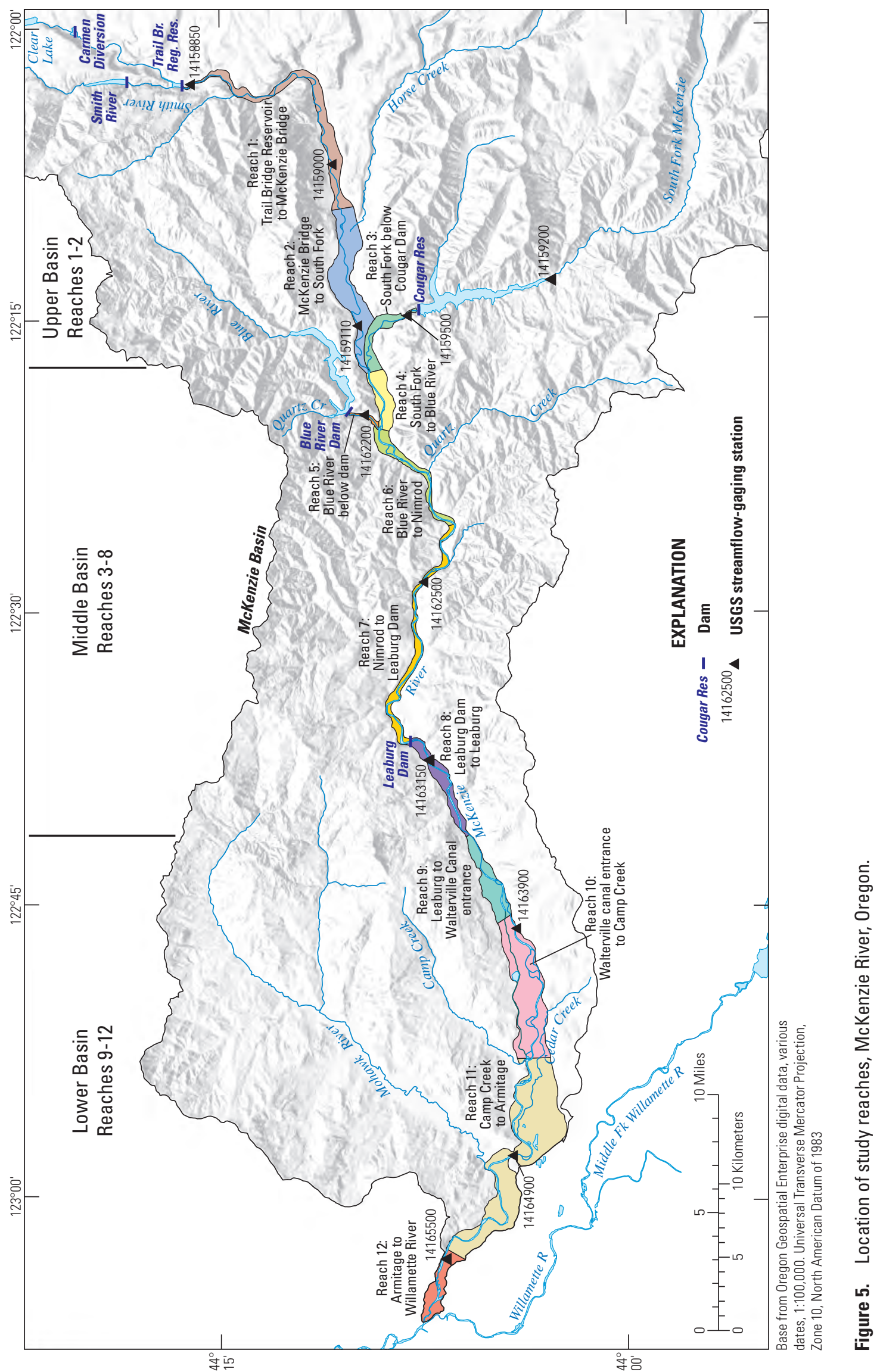




\section{Streamflow Regulation}

Since the early 1900s, streamflow in the McKenzie River basin has been altered through the construction of dams and canals (fig. 6; table 3). EWEB owns and operates the Walterville and Leaburg canals, completed in 1910 and 1930, respectively, which are operated for hydropower production. With the exception of canal seepage losses and minor withdrawals, most of the diverted water returns to the McKenzie River. Under the current Federal Energy Regulatory Commission (FERC) license, EWEB diverts as much as 2,500 $\mathrm{ft}^{3} / \mathrm{s}$ for its Leaburg and 2,577 $\mathrm{ft}^{3} / \mathrm{s}$ for its Walterville power canals so long as a minimum of $1,000 \mathrm{ft}^{3} / \mathrm{s}$ remains in the McKenzie River. However, EWEB provides a minimum flow in the river of $1,050 \mathrm{ft}^{3} / \mathrm{s}$. An additional $40 \mathrm{ft}^{3} / \mathrm{s}$ is provided to the Leaburg fish hatchery. Streamflows at the USGS streamflow-gaging stations near Leaburg (14163150) and Walterville (14163900) are monitored in real time and used to control canal diversions.

In the early 1960s, EWEB constructed the Carmen-Smith River Hydroelectric Project. From the Carmen diversion reservoir, water is diverted through a tunnel into the adjacent Smith River subbasin (also within the McKenzie River basin) (fig. 6). The Smith River dam is used to provide a sufficient elevation drop for the production of electricity. Flow from the dam goes through a power tunnel to the Carmen powerhouse. Water passing through the Carmen powerhouse is discharged at the head of Trail Bridge Reservoir near the confluence of the Smith and McKenzie Rivers. Trail Bridge Dam is used for reregulating the outflow of the Carmen-Smith Hydroelectric Project to closely match the inflow at Carmen Diversion Dam.

In the 1960s, the USACE constructed the Cougar and Blue River Dams on the South Fork McKenzie and Blue Rivers, respectively. Having a combined useable storage of about 236,000 acre-ft, both dams are used for flood control, navigation (Willamette River), downstream irrigation, fisheries, water quality, and recreation (U.S. Army Corps of Engineers, 2009a, 2009b). Cougar Dam also is used for hydropower production.

Upstream of Vida, McKenzie River basin withdrawals for consumptive water use are minimal in relation to total streamflow because the upper basin is almost entirely managed by the U.S. Forest Service (USFS) and has limited agricultural and residential water demands. As a consequence, the upper basin dams (Cougar, Blue River, and Carmen-Smith-Trail Bridge) historically have not changed annual streamflow. Their effect has been more on the annual distribution of daily streamflows, which is discussed in the Hydrology section. Most water withdrawals in the McKenzie River basin occur in the lower basin (Reaches 9-12) between Leaburg and Eugene. The largest water users are EWEB (water intake at Hayden Bridge near Springfield), the Weyerhaeuser plant near Springfield, the Springfield Utility Board, and the Leaburg fish hatchery. Other water withdrawals in the basin, mostly through groundwater pumping, are for agriculture and residential use.

Table 3. Dams in the McKenzie River basin, Oregon.

[Data from the U.S. Army Corps of Engineers and the Eugene Water and Electric Board. Purpose: F, fisheries; FC, flood control; HP, hydropower; I, irrigation; N, navigation; QW, water quality; R, recreation. Abbreviations: NAVD88, North American Vertical Datum of 1988; na, not applicable or available; mi ${ }^{2}$, square miles; acre-ft, acre-foot; kW, kilowatt]

\begin{tabular}{|c|c|c|c|c|c|c|c|c|c|}
\hline Dam name & River name & $\begin{array}{c}\text { Year } \\
\text { completed }\end{array}$ & $\begin{array}{c}\text { Lake pool } \\
\text { minimum } \\
\text { (ft above } \\
\text { NAVD88) }\end{array}$ & $\begin{array}{c}\text { Elevation } \\
\text { maximum } \\
\text { (ft above } \\
\text { NAVD88) }\end{array}$ & $\begin{array}{c}\text { Upstream } \\
\text { drainage } \\
\text { area } \\
\left(\mathrm{mi}^{2}\right)\end{array}$ & $\begin{array}{c}\text { Reservoir } \\
\text { useable } \\
\text { storage } \\
\text { (acre-ft) }\end{array}$ & $\begin{array}{c}\text { Reservoir } \\
\text { surface } \\
\text { area } \\
\text { (acres) }\end{array}$ & Purpose & $\begin{array}{c}\text { Maximum } \\
\text { power } \\
\text { output } \\
\text { (kW) }\end{array}$ \\
\hline Carmen Diversion & McKenzie & 1963 & 2,600 & 2,625 & 94.6 & na & 30 & diversion for HP & na \\
\hline Smith & Smith & 1963 & na & 2,605 & 17.6 & 15,050 & 170 & HP & 108,000 \\
\hline Trail Bridge & McKenzie & 1963 & na & 2,092 & 184 & 2,100 & 73 & re-regulation & 10,000 \\
\hline Blue River & Blue River & 1969 & 1,132 & 1,357 & 88 & 82,800 & 1,009 & $\mathrm{~F}, \mathrm{FC}, \mathrm{I}, \mathrm{N}, \mathrm{QW}, \mathrm{R}$ & na \\
\hline Leaburg Diversion & McKenzie & 1930 & na & na & 1,020 & na & na & diversion for HP & 13,500 \\
\hline Walterville $^{1}$ & McKenzie & 1910 & na & na & 1,080 & na & na & diversion for HP & 9,000 \\
\hline
\end{tabular}

${ }^{1}$ Instead of a dam, chevrons are used for streamflow diversion to the Walterville power canal. 


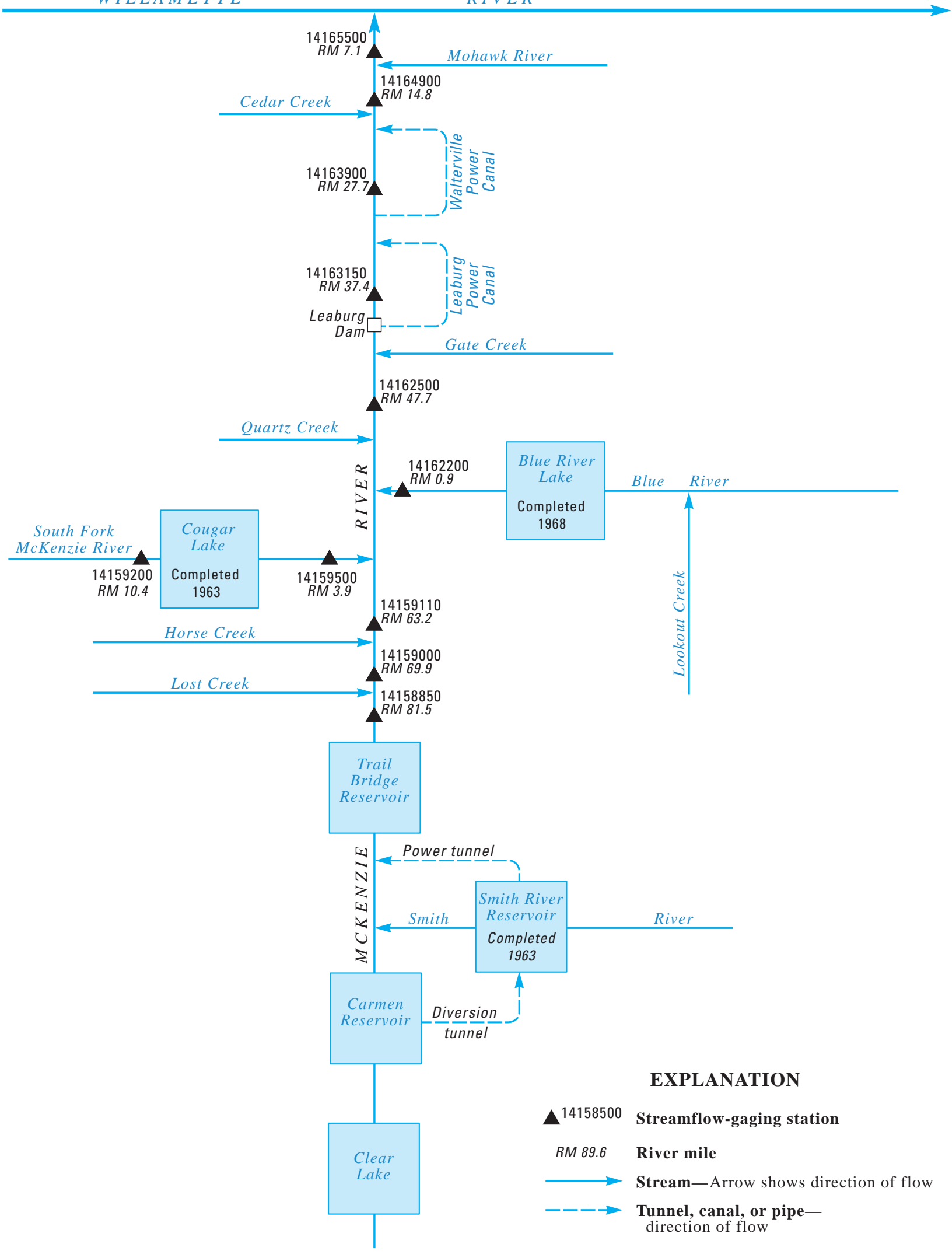

Figure 6. Dams, canal diversions, streamflow-gaging and stream-temperature stations in the McKenzie River basin, Oregon. 


\section{Previous McKenzie River Basin Studies}

In recent years, numerous research papers and reports have been published specific to hydrologic, ecological, and biological issues in the McKenzie and Willamette River basins. Stearns (1928), Ingrebritsen and others (1994), Manga (1997), Tague and Grant (2004), Jefferson and others (2006), and Tague and others (2007) discussed the geologic framework of the High Cascades in the upper McKenzie River basin and its relationship to spring-dominated streamflow. For more than 50 years, research on forest hydrologic, geomorphic, and ecological dynamics has been based on field data collected in the H.J. Andrews Experimental Forest, which is a Long-Term Ecological Research (LTER) site in the Lookout Creek basin (in the Blue River basin) (H.J. Andrews Experimental Forest, 2009).

In the 1990s, the USFS, BLM, and Weyerhaeuser produced a series of watershed analyses for various streams in the basin. Many of these studies were related to timber harvesting and its effects on fisheries and ecological habitat. These analyses included the lower and middle reaches of the McKenzie River (Bureau of Land Management, 1998a, 1998b), the upper McKenzie River basin (U.S. Forest Service, 1995), Blue River (U.S. Forest Service, 1996), Horse Creek (U.S. Forest Service, 1997), South Fork McKenzie River (U.S. Forest Service, 1994), Quartz Creek (Ecosystems Northwest, 1998), and the south and north sides of the lower McKenzie River basin (Weyerhaeuser, 1994, 1995).

A series of publications has resulted from the Federal Energy Regulatory Commission (FERC) relicensing applications for the EWEB projects (Eugene Water and Electric Board, 2008a, 2008b; Karl Morgenstern, Eugene Water and Electric Board, oral commun., 2009). The Walterville and Leaburg hydroelectric projects were relicensed by FERC in 1997, and those licenses will not expire until 2037. An outcome of the relicensing was implementing minimum streamflows of $1,000 \mathrm{ft}^{3} / \mathrm{s}$ in the reaches of the McKenzie River where EWEB diverts as much as 2,500 ft $\mathrm{ft}^{3} / \mathrm{s}$ for its Leaburg power canal and 2,577 $\mathrm{ft}^{3} / \mathrm{s}$ for its Walterville power canal. The Carmen-Smith Hydroelectric Project Final License Application was submitted to FERC in November 2006 and a Settlement Agreement with 16 signatories was submitted in October 2008 (Stillwater Sciences, 2006a, 2006b; Eugene Water and Electric Board, 2008b). Because the Cougar and Blue River Dams are owned by a Federal agency (USACE) and not a power utility, they are not regulated under the FERC relicensing process.

Bull trout (Salvelinus confluentus) throughout the Klamath and Columbia River basins was listed as threatened by the U.S. Fish and Wildlife Service (USFWS) in 1998. In early 1999, the National Marine Fisheries Service (NMFS) listed spring Chinook salmon (Oncorhynchus tshawytscha) in the McKenzie River basin and other upper Willamette River basins as threatened. As a result of these listings, Endangered Species Act (ESA) consultations began between the Federal agencies whose operations were affecting the listed species (known as "Action Agencies") and the NMFS and USFWS (known as the "Services"). During an ESA consultation, the Action Agencies are required to create Biological Assessments (BA), which are submitted to the Services. The BA also includes a proposed recovery plan that outlines how the Action Agency will reduce its effect on the critical habitat of the listed species. In the Willamette ESA consultation, the Action Agencies include the USACE, Bonneville Power Administration, and Bureau of Reclamation. The USACE submitted its first BA in 2000 and a supplemental BA in 2007 for the Willamette River basin that included specific recovery plans for the McKenzie River basin (U.S. Army Corps of Engineers, 2000, 2007). In July 2008, NMFS released their decision on the BA plans through a Willamette Project Biological Opinion (National Marine Fisheries Service, 2008a, 2008b). NMFS decided that the BA plans were insufficient for mitigating the effect of the water projects on critical habitat. The Biological Opinion ordered additional measures, which included improved fish passage, temperature control, and changes in downstream streamflows. Included in the Biological Opinion are flow release targets for Cougar and Blue River dams for different seasonal life histories for the ESA-listed fish (table 4).

Table 4. Minimum and maximum streamflow objectives below Blue River and Cougar Dams, McKenzie River, Oregon.

[Data from National Marine Fisheries Service (2008b). Abbreviations: $\mathrm{ft}^{3} / \mathrm{s}$, cubic feet per second; -, no data]

\begin{tabular}{lllc}
\hline \multirow{2}{*}{ Period } & \multicolumn{1}{c}{ Primary use } & \multicolumn{2}{c}{ Streamflow $\left(\mathbf{f t}^{3} \mathbf{s}\right)$} \\
\cline { 3 - 4 } & \multicolumn{1}{c}{ Blue River Dam } & & \\
\hline & Minimum & Maximum \\
\hline September 1 - October 15 & Chinook spawning & 50 & - \\
October 16 - January 31 & Chinook incubation & 50 & - \\
February 1 - August 31 & Rearing & 50 & - \\
\hline & \multicolumn{1}{c}{ Cougar Dam } & & \\
\hline September 1 - October 15 & Chinook spawning & 300 & 580 \\
October 16 - January 31 & Chinook incubation & 300 & - \\
February 1 - May 31 & Rearing & 300 & - \\
June 1 - June 30 & Rearing/adult migration & 400 & - \\
July 1 - July 31 & Rearing & 300 & - \\
August 1 - August 31 & Rearing & 300 & - \\
\hline
\end{tabular}


As a result of the Willamette River ESA listings and consultation, a coordinated effort by various Willamette River basin stakeholders to improve critical habitat was made under the auspices of the Willamette Restorative Initiative. The group submitted the Willamette Subbasin Plan, which included proposals to modify streamflow releases from dams in the Willamette River basin (Northwest Power and Conservation Council, 2004).

Aside from the ESA consultations, ecosystem habitat issues in the McKenzie River basin also are driven by stream temperature. Before the construction of the selective withdrawal tower at Cougar Dam, Hansen (1988) modeled the effects of the dam operations on downstream water temperatures. More recently Rounds (2007) modeled water temperatures downstream of Cougar Dam using observed dam streamflow releases made with the selective withdrawal tower (completed in 2005) in operation. The Oregon Department of Environmental Quality (ODEQ), as required under the Federal Clean Water Act, has developed stream-temperature Total Maximum Daily Load (TMDL) allocations for many streams in Oregon. In 2006, ODEQ finalized a TMDL plan for the Willamette River basin. Some stream reaches within the McKenzie River basin were listed as having exceeded their temperature TMDL as a result of dam streamflow releases, canal streamflow diversions, and limited riparian shade (Oregon Department of Environmental Quality, 2006).

\section{Hydrology}

\section{Key Elements}

- Since 1906, daily mean streamflow has been measured by the USGS at 29 active and now inactive sites.

- The Carmen-Smith-Trail Bridge hydropower dam complex decreased the frequency of large floods (greater than 10-year recurrence interval) in Reach 1 by 71 percent. No significant change has occurred in other environmental flow components.

- Large floods on the South Fork McKenzie (Reach 3) below Cougar Dam have been eliminated. Small floods (5-10 year recurrence interval) decreased in frequency and magnitude. The magnitude of high flow pulses decreased and of low flows increased. The timing of the lowest annual streamflow shifted from September to March. Monthly streamflows from February to May decreased, and monthly streamflows from July to November increased.
- Small and large floods below Blue River Dam (Reach 5) have been eliminated. Low flows have increased and the timing of the lowest annual streamflow has shifted from September to March. Monthly streamflows have decreased from February to May and increased from July to November.

- The frequency and magnitude of small and large floods has decreased in Reaches 7-12 (downstream of the dams). Low flows have increased in magnitude. No significant change in the timing of the annual lowest streamflow has occurred. Monthly streamflows during March-May have decreased and have increased during July-November.

\section{Methods}

\section{Streamflow Data}

The USGS has collected daily mean streamflow data at 29 streamflow-gaging stations in the McKenzie River basin since 1906 (table 5). Thirteen of these stations were active through water year 2008. The stations with the longest streamflow time series are the McKenzie River at McKenzie Bridge (14159000: 1910-1994) and the McKenzie River near Vida (14162500: 1925-2008). These daily streamflow time series were used to estimate a daily streamflow time series for each of the 12 study reaches.

\section{Measured and Estimated Streamflow}

Pre- and post-dam streamflow time series were assembled for each reach. Nine of the 12 study reaches included active or inactive USGS streamflow-gaging stations located at midpoints of the reaches and were considered representative of streamflow for the entire reach. It was necessary to extend existing records for most gaged reaches and to estimate streamflows for Reaches 4, 6, and 9, which did not have a streamflow-gaging station (table 6). Streamflow records for Reaches 8 and 10 were not extended into the pre-dam period because of limited data and because streamflow in those reaches have been diverted through the Leaburg and Waterville Canals since the 1930s. Additional details of the streamflow estimation procedure are included in appendix A. 
Table 5. U.S. Geological Survey streamflow-gaging stations in the McKenzie River basin, Oregon.

[Period of record: A water year is from October 1 to September 30. Abbreviations: mi² $^{2}$, square miles; na, not applicable]

\begin{tabular}{|c|c|c|c|}
\hline $\begin{array}{l}\text { Station } \\
\text { No. }\end{array}$ & Streamflow-gaging station name & $\begin{array}{c}\text { Drainage } \\
\text { area } \\
\left(\mathrm{mi}^{2}\right)\end{array}$ & $\begin{array}{l}\text { Period of record } \\
\text { (water years) }\end{array}$ \\
\hline 14158500 & McKenzie River at Outlet of Clear Lake & 92.4 & $1947-2008$ \\
\hline 14158700 & McKenzie River near Belknap Springs & 146 & $1958-62$ \\
\hline 14158790 & Smith River above Smith River Reservoir, near Belknap Springs & 16.2 & $1960-2008$ \\
\hline 14158800 & Smith River near Belknap Springs & 23.7 & $1958-60$ \\
\hline 14158850 & McKenzie River below Trail Bridge Dam, near Belknap Springs & 184 & $1960-2008$ \\
\hline 14158930 & Budworm Creek near Belknap Springs & 3 & $1979-83 ; 1984-86$ \\
\hline 14159000 & McKenzie River at McKenzie Bridge & 348 & 1911-94 \\
\hline 14159100 & Horse Creek near McKenzie Bridge & 150 & $1963-69$ \\
\hline 14159110 & McKenzie River above South Fork, near Rainbow & 526 & $2003-06$ \\
\hline 14159200 & South Fork McKenzie River above Cougar Lake, near Rainbow & 160 & $1957-87 ; 2000-08$ \\
\hline 14159500 & South Fork McKenzie River near Rainbow & 208 & 1948-2008 \\
\hline 14160000 & Mann Creek near McKenzie Bridge, & 5.12 & $1949-52$ \\
\hline 14160500 & Wolf Creek near McKenzie Bridge & 2.1 & $1949-52$ \\
\hline 14161000 & Blue River above Quentin Creek & 11.5 & $1948-55$ \\
\hline 14161100 & Blue River below Tidbits Creek, near Blue River & 45.8 & $1963-2004$ \\
\hline 14161500 & Lookout Creek near Blue River & 24.1 & $1949-55 ; 1963-2008$ \\
\hline 14162000 & Blue River near Blue River & 75 & $1936-64$ \\
\hline 14162200 & Blue River at Blue River & 87.7 & $1967-2008$ \\
\hline 14162500 & McKenzie River near Vida & 930 & $1925-2008$ \\
\hline 14163000 & Gate Creek at Vida & 47.6 & $1952-57 ; 1967-90$ \\
\hline 14163150 & McKenzie River below Leaburg Dam, near Leaburg & 1,030 & 1990-2008 \\
\hline 14163500 & Eugene Power Canal near Walterville & na & $1927-33$ \\
\hline 14163900 & McKenzie River near Walterville & 1,081 & $1990-2008$ \\
\hline 14164000 & McKenzie River near Springfield & 1,066 & $1906-15$ \\
\hline 14164500 & Mill Creek at Wendling & 23 & $1935-37$ \\
\hline 14164700 & Cedar Creek at Springfield & 9.62 & $2001-08$ \\
\hline 14164900 & McKenzie River above Hayden Bridge, at Springfield & 1,140 & 2008 \\
\hline 14165000 & Mohawk River near Springfield & 177 & ${ }^{1} 1935-52 ; 1998-2008$ \\
\hline 14165500 & McKenzie River near Coburg & 1,337 & $1945-72$ \\
\hline
\end{tabular}

${ }^{1}$ Streamflow record has more than one break between the starting and ending years. 
Table 6. Streamflow-gaging stations or streamflow points of the study reach, McKenzie River basin, Oregon.

[River mile from the nearest downstream confluence. For reaches without a streamflow-gaging station, a river mile at a midpoint in the reach was selected. Data period: A water year is from October 1 to September 30. Abbreviations: $\mathrm{mi}^{2}$, square miles; na, no streamflow gage in this reach]

\begin{tabular}{|c|c|c|c|c|c|c|}
\hline $\begin{array}{c}\text { Reach } \\
\text { No. }\end{array}$ & $\begin{array}{c}\text { Station } \\
\text { No. }\end{array}$ & Streamflow-gaging station name & $\begin{array}{c}\text { Drainage } \\
\text { area } \\
\left(\mathrm{mi}^{2}\right)\end{array}$ & $\begin{array}{l}\text { River } \\
\text { mile }\end{array}$ & \multicolumn{2}{|c|}{ Data period (water years) } \\
\hline 1 & 14158850 & McKenzie River below Trail Bridge Dam near Belknap Springs & 184 & 81.5 & $1936-59$ & 1960-2008 \\
\hline 2 & 14159110 & McKenzie River above South Fork, near Rainbow & 526 & 62.3 & $\begin{array}{l}\text { 1936-2002; } \\
\text { 2007-08 }\end{array}$ & $2003-06$ \\
\hline 3 & 14159500 & South Fork McKenzie River near Rainbow & 208 & 3.9 & $1936-47$ & 1948-2008 \\
\hline 4 & na & & 748 & 58 & $1936-2008$ & \\
\hline 5 & 14162200 & Blue River at Blue River & 87.7 & .9 & $1936-66$ & 1967-2008 \\
\hline 6 & na & & 897 & 53 & $1925-2008$ & \\
\hline \multicolumn{7}{|c|}{ Lower basin } \\
\hline 9 & na & & 1,070 & 30 & $1925-2008$ & \\
\hline 10 & 14163900 & McKenzie River near Walterville & 1,081 & 27.7 & na & 1990-2008 \\
\hline 11 & 14164900 & McKenzie River above Hayden Bridge, at Springfield & 1,140 & 14.8 & 1936-2007 & 2008 \\
\hline 12 & 14165500 & McKenzie River near Coburg & 1,337 & 7.1 & $\begin{array}{l}1936-44 \\
1973-2008\end{array}$ & $1945-72$ \\
\hline
\end{tabular}

\section{Computed Unregulated Streamflow}

In addition to the USGS measured streamflow data, the USACE computed unregulated daily streamflow time series for water years 1936-2004 at locations on the South Fork McKenzie River near Rainbow, Oregon [below Cougar Dam] (14159500), Blue River at Blue River, Oregon [below Blue River Dam] (14162200), and the McKenzie River near Vida, Oregon (14162500) (Julie Ammann, U.S. Army Corps of Engineers, written commun., 2008). These time series are an estimate of streamflow at these three locations if the two USACE dams had not been constructed. For this study, these time series were used to evaluate the hydrologic effect of the dams by comparing pre- and post-dam streamflow conditions.

The time series for the South Fork McKenzie River and Blue River sites were computed using correlations with nearby unregulated USGS streamflow records in McKenzie and Middle Fork River basins. Details on how the unregulated time series were computed are provided in appendix B. For this study, these two time series were extended by an additional 4 years (water years 2005-08) based on the USACE methods. The daily streamflow time series for the unregulated McKenzie River near Vida (14162500) was computed by first routing measured South Fork McKenzie (14159500) and Blue River (14152500) daily mean streamflows to McKenzie River near Vida (14162500). These two routed daily time series were then subtracted from measured Vida (14162500) daily mean streamflows to compute a time series for the local drainage basin upstream of Vida and downstream of the dams. The local time series and the computed unregulated Cougar Dam (14159500) and Blue River Dam (14152500) time series were then summed into a single daily time series. 


\section{Simulated Regulated Streamflow}

USACE also simulated regulated daily streamflow time series for water years 1937-2004 at the Cougar and Blue River Dams and the Vida streamflow-gaging station using the USACE HEC-ResSim model (Julie Ammann, U.S. Army Corps of Engineers, written commun., 2009). In the simulations, the two dams were assumed to have existed for the entire 68-year period and operated consistent with releases from the dams based on the reservoir operation plans in accordance with the Biological Opinion released by NMFS in 2008 (National Marine Fisheries Service, 2008b). For this study, these time series were used to compare measured pre-dam streamflow conditions with hypothetical post-dam streamflow conditions (based on the Biological Opinion operation plans).

\section{Bankfull Streamflow Estimation}

In geomorphology, bankfull streamflow is often used as determinant of the size and shape of a river channel and can be defined as the discharge just contained within the banks. Using USGS measured stage and discharge data, measurement notes, photographs, and rating curves, bankfull stage and streamflows were estimated at the seven study reaches that have streamflow-gaging stations (table 7). The estimates have substantial uncertainty and are not necessarily representative of the entire reach. Bankfull streamflow estimates also were made for Reaches 4, 6, and 9, which do not have streamflowgaging stations, based on an interpolation of estimates from the upstream and downstream reaches. Estimates were not made for Leaburg and Walterville power canal reaches (Reaches 8 and 10) because of the flow diversion from the river.

Table 7. Estimated bankfull gage heights and streamflows at study reach streamflow sites, McKenzie River basin, Oregon.

[Abbreviations: $\mathrm{ft}$, foot; $\mathrm{ft}^{3} / \mathrm{s}$, cubic foot per second. na, no streamflow gage in this reach]

\begin{tabular}{|c|c|c|c|c|}
\hline $\begin{array}{c}\text { Reach } \\
\text { No. }\end{array}$ & $\begin{array}{c}\text { Station } \\
\text { No. }\end{array}$ & Streamflow-gaging station name & $\begin{array}{c}\text { Approximate } \\
\text { gage height } \\
\text { (ft) }\end{array}$ & $\begin{array}{c}\text { Approximate } \\
\text { bankfull flow } \\
\left(\mathrm{ft}^{3} / \mathrm{s}\right)\end{array}$ \\
\hline \multicolumn{5}{|c|}{ Upper basin } \\
\hline 1 & 14158850 & McKenzie River below Trail Bridge Dam, near Belknap Springs & 8.5 & 2,500 \\
\hline 2 & 14159110 & McKenzie River above South Fork, near Rainbow & 11.5 & 7,000 \\
\hline \multicolumn{5}{|c|}{ Middle basin } \\
\hline 3 & 14159500 & South Fork McKenzie River near Rainbow & 4.5 & 5,000 \\
\hline 4 & na & & na & 13,000 \\
\hline 5 & 14162200 & Blue River at Blue River & 7.5 & 3,000 \\
\hline 6 & na & & na & 17,000 \\
\hline 7 & 14162500 & McKenzie River near Vida & 8 & 20,000 \\
\hline 8 & 14163150 & McKenzie River below Leaburg Dam, near Leaburg & (canal) & na \\
\hline \multicolumn{5}{|c|}{ Lower basin } \\
\hline 9 & na & & na & 22,500 \\
\hline 10 & 14163900 & McKenzie River near Walterville & (canal) & na \\
\hline 11 & 14164900 & McKenzie River above Hayden Bridge, at Springfield & 15 & 25,000 \\
\hline 12 & 14165500 & McKenzie River near Coburg & 7 & 25,000 \\
\hline
\end{tabular}


The National Weather Service also uses the same estimate of bankfull stage ( $8 \mathrm{ft})$ and streamflow $\left(20,000 \mathrm{ft}^{3} / \mathrm{s}\right)$ for the USGS streamflow-gaging station near Vida (14167500) (Reach 7) (National Weather Service, 2009). Since the construction of Cougar Dam in 1963 and Blue River Dam in 1969, USACE regulates streamflows at the Vida gaging station within the bankfull level to avoid flood damage. Daily mean streamflows at the gaging station have exceeded the bankfull streamflow estimate of $20,000 \mathrm{ft}^{3} / \mathrm{s}$ in only 5 years during water years 1969-2008.

\section{Indicators of Hydrologic Alteration}

A statistical analysis of daily mean streamflow time series was used to quantify hydrologic changes resulting from construction and operation of dams and diversion canals in McKenzie River basin using the Indicators of Hydrologic Alteration (IHA) statistical software package developed by The Nature Conservancy (2007). The software package allows the user to analyze a daily mean streamflow time series as a single time period or divided into pre- and post-dam periods. For each user-defined time period, the software package computes 33 IHA metrics, which include mean monthly streamflows, annual streamflow extremes (1-day maximum and 7-day minimum), Julian day timing of streamflow extremes, low and high streamflow pulses, rise and fall rates, and the number hydrologic reversals (table 8). These metrics have specific linkages to ecosystem processes and functions.

The software package also separates daily mean streamflows into five categories, which are referred to as Environmental Flow Components (EFC), by using a simple algorithm. EFCs include extreme low flows, low flows, high-flow pulses, small floods (2-year events), and large floods (10-year events). The algorithm first separates all daily streamflows into either the high-flow pulse or low-flow groups. The highest 25 percent of daily streamflows (that is, greater than the 75 th streamflow percentile) are assigned to the high-flow pulse group, and streamflows less than the median of the streamflows are assigned to the low-flow group. Daily mean streamflows between the 50th and 75th percentiles are assigned to the high-flow pulse group if that streamflow increased by 25 percent or more above the streamflow of the previous day, which also signifies the start of a high-flow pulse event. The high-flow pulse event ends when streamflows decrease by less than 10 percent per day. The high-flow pulse events are then categorized as a "small" or "large" flood if it has a recurrence interval (annual probability) of at least 2 years (50 percent) and less than 10 years (10 percent) or greater than 10 years (10 percent), respectively. IHA uses Weibull plotting positions to determine annual flood frequencies. This method is different from the Bulletin 17B Log Pearson III peak streamflow method (Interagency Advisory Committee on Water Data, 1981). Of the remaining streamflows that were categorized as low flows, an extreme low flow is a streamflow in the lowest 10 percent of the low flows. In this study, the time series were divided into pre- and post-dam periods, and the thresholds for the five categories (or components) are based on the pre-dam period data, which reflect unaltered streamflow conditions.

For each user-defined time period, the software package computes 34 EFC metrics (in addition to the 33 IHA metrics), which include the duration (days), magnitude (maximum or minimum streamflow of the event), timing (Julian day of the peak or minimum), and rise and fall rates for each of the five EFC categories (table 9). Complete IHA and EFC analysis results for all 12 reaches are included in appendix C.

The Indicators of Hydrologic Alteration software includes a "significance count" as a means of testing if the difference between pre- and post-impact period metrics is significant. The significance count value ranges from 0 to 1 . A significance count value close to 0 indicates that the difference between the pre- and post-impact periods is highly significant. The value can be interpreted similarly to a p-value used in statistical tests. For this study, significance count values less than or equal to 0.05 were considered significant. Additional information about the test is included in appendix C.

Additional metrics used in the analyses of hydrologic alteration caused by dams that were not included in the IHA software package were pre- and post-dam period 2-, 10-, 50-, and 100-year flood statistics computed from annual peak streamflow data using the Bulletin 17B Log Pearson III method (Interagency Advisory Committee on Water Data, 1981) and streamflow durations (10th, 50th, and 90th percent exceedances) computed from daily mean streamflow data. 
Table 8. Indicators of Hydrologic Alteration parameters used to quantify hydrologic changes resulting from dams and canals, McKenzie River, Oregon.

[Data from The Nature Conservancy (2007)]

\begin{tabular}{|c|c|c|}
\hline $\begin{array}{l}\text { Hydrologic Alteration Indicators (IHA) } \\
\text { parameter group }\end{array}$ & Hydrologic parameters & Ecosystem influences \\
\hline $\begin{array}{l}\text { 1. Magnitude of monthly water } \\
\text { conditions }\end{array}$ & $\begin{array}{l}\text { Mean or median value for each } \\
\text { calendar month }\end{array}$ & $\begin{array}{l}\text { * Habitat availability for aquatic organisms } \\
\text { * Soil moisture availability for plants } \\
\text { * Availability of water for terrestrial animals } \\
\text { * Availability of food/cover for fur-bearing mammals } \\
\text { * Reliability of water supplies for terrestrial animals } \\
\text { * Access by predators to nesting sites } \\
\text { * Influences water temperature, oxygen levels, photosynthesis in water } \\
\text { column }\end{array}$ \\
\hline $\begin{array}{l}\text { 2. Magnitude and duration of annual } \\
\text { extreme water conditions }\end{array}$ & $\begin{array}{l}\text { Annual minima, 1-day mean } \\
\text { Annual minima, 3-day means } \\
\text { Annual minima, 7-day means } \\
\text { Annual minima, 30-day means } \\
\text { Annual minima, 90-day means } \\
\text { Annual maxima, 1-day mean } \\
\text { Annual maxima, 3-day means } \\
\text { Annual maxima, 7-day means } \\
\text { Annual maxima, 30-day means } \\
\text { Annual maxima, 90-day means } \\
\text { Number of zero-flow days } \\
\text { Base flow index: 7-day minimum } \\
\text { flow/annual mean flow }\end{array}$ & $\begin{array}{l}\text { * Balance of competitive, ruderal, and stress-tolerant organisms } \\
\text { * Creation of sites for plant colonization } \\
\text { * Structuring of aquatic ecosystems by abiotic versus biotic factors } \\
\text { * Structuring of river channel morphology and physical habitat conditions } \\
\text { * Soil moisture stress in plants } \\
\text { * Dehydration in animals } \\
\text { * Anaerobic stress in plants } \\
\text { * Volume of nutrient exchanges between rivers and floodplains } \\
\text { * Duration of stressful conditions such as low oxygen and concentrated } \\
\text { chemicals in aquatic environments } \\
\text { * Distribution of plant communities in lakes, ponds, floodplains } \\
\text { * Duration of high flows for waste disposal, aeration of spawning beds in } \\
\text { channel sediments }\end{array}$ \\
\hline $\begin{array}{l}\text { 3. Timing of annual extreme water } \\
\text { conditions }\end{array}$ & $\begin{array}{l}\text { Julian date of each annual 1-day } \\
\text { maximum } \\
\text { Julian date of each annual 1-day } \\
\text { minimum }\end{array}$ & $\begin{array}{l}\text { * Compatibility with life cycles of organisms } \\
\text { * Predictability/avoidability of stress for organisms } \\
\text { * Access to special habitats during reproduction or to avoid predation } \\
\text { * Spawning cues for migratory fish } \\
\text { * Evolution of life history strategies, behavioral mechanisms }\end{array}$ \\
\hline $\begin{array}{l}\text { 5. Rate and frequency of water condition } \\
\text { changes }\end{array}$ & $\begin{array}{l}\text { Rise rates: Mean or median of } \\
\text { all positive differences } \\
\text { between consecutive daily values } \\
\text { Fall rates: Mean or median of } \\
\text { all negative differences } \\
\text { between consecutive daily values } \\
\text { Number of hydrologic reversals }\end{array}$ & $\begin{array}{l}\text { * Drought stress on plants (falling levels) } \\
\text { * Entrapment of organisms on islands, floodplains (rising levels) } \\
\text { * Desiccation stress on low-mobility stream edge (varial zone) organisms }\end{array}$ \\
\hline
\end{tabular}


Table 9. Environmental flow component parameters from the Indicators of Hydrologic Alteration software package and their ecosystem influences.

[Data from The Nature Conservancy (2007)]

\section{Environmental flow component type}

1. Monthly low flows Mean or median values of low flows during each calendar month

\section{Hydrologic parameters}

\section{Ecosystem influences}

* Provide adequate habitat for aquatic organisms

* Maintain suitable water temperatures, dissolved oxygen, and water chemistry

* Maintain water table levels in floodplain, soil moisture for plants

* Provide drinking water for terrestrial animals

* Keep fish and amphibian eggs suspended

* Enable fish to move to feeding and spawning areas

* Support hyporheic organisms (living in saturated sediments)

2. Extreme low flows Frequency of extreme low flows during each water * Enable recruitment of certain floodplain plant species year or season

* Purge invasive, introduced species from aquatic and riparian communities

Mean or median values of extreme low flow event: * Concentrate prey into limited areas to benefit predators

* Duration (days)

* Magnitude (minimum flow during event)

* Timing (Julian date of event)

3. High flow pulses Frequency of high flow pulses during each water year or season

Mean or median values of high flow pulse event:

* Duration (days)

* Magnitude (maximum flow during event)

* Timing (Julian date of peak flow)

* Rise and fall rates

Frequency of small floods during each water year or season

Mean or median values of small flood event:

* Duration (days)

* Magnitude (maximum flow during event)

* Timing (Julian date of peak flow)

* Rise and fall rates
* Shape physical character of river channel, including pools, riffles

* Determine size of streambed substrates (sand, gravel, cobble)

* Prevent riparian vegetation from encroaching into channel

* Restore normal water quality conditions after prolonged low flows, flushing away waste products and pollutants

* Aerate eggs in spawning gravels, prevent siltation

* Maintain suitable salinity conditions in estuaries

Applies to small and large floods:

* Provide migration and spawning cues for fish

* Trigger new phase in life cycle (for example, insects)

* Enable fish to spawn in floodplain, provide nursery area for juvenile fish

* Provide new feeding opportunities for fish, waterfowl

* Recharge floodplain water table

* Maintain diversity in floodplain forest types through prolonged inundation (for example, different plant species have different tolerances)

* Control distribution and abundance of plants on floodplain

* Deposit nutrients on floodplain

5. Large floods $\quad$ Frequency of large floods during each water year or season

Applies to small and large floods:

* Maintain balance of species in aquatic and riparian communities

* Create sites for recruitment of colonizing plants

* Shape physical habitats of floodplain

* Deposit gravel and cobbles in spawning areas

Mean or median values of large flood event:

* Duration (days)

* Magnitude (maximum flow during event)

* Timing (Julian date of peak flow)

* Rise and fall rates
* Flush organic materials (food) and woody debris (habitat structures) into channel

* Purge invasive, introduced species from aquatic and riparian communities

* Disburse seeds and fruits of riparian plants

* Drive lateral movement of river channel, forming new habitats (secondary channels, oxbow lakes)

* Provide plant seedlings with prolonged access to soil moisture 


\section{Hydrology Results and Discussion}

The effects of dams and canals on streamflow regime are described below for selected reaches in the McKenzie River basin. Statistical metrics computed using the IHA software compare the pre- and post-dam periods in the context of different environmental flow components, such as low streamflows, high-flow pulses, small floods, and large floods. Graphical comparisons of pre- and post-streamflow regulation include mean daily streamflow plots based on measured and estimated daily mean streamflow data. Mean daily streamflow plots are created by computing the mean of all daily mean streamflows for each calendar day from a record of a site. (This is different from daily mean streamflow, which is the computed mean streamflow on a specific day). Because a mean daily streamflow plot dampens the magnitude of floods, comparisons of measured daily mean streamflows and USACE computed unregulated daily streamflows for a single water year (1995) also are included. Water year 1995 data were used in the daily mean streamflow comparison plots because it approximates an average year in the historic record based on a comparison of mean annual streamflows. Mean annual streamflows for water year 1995 and the period of record (water years 1925-2008) for the McKenzie River near Vida streamflow-gaging station (14162500) are 4,026 and $4,039 \mathrm{ft}^{3} / \mathrm{s}$, respectively. The driest and wettest mean annual streamflows for this period were $2,447 \mathrm{ft}^{3} / \mathrm{s}$ (water year 1977) and 6,211 $\mathrm{ft}^{3} / \mathrm{s}$ (water year 1956), respectively.

A reach by reach summary of the hydrologic changes to the environmental flow components is provided in table 10. The Carmen-Smith-Trail Bridge Dam complex has caused minor hydrologic alterations in Reach 1 in the form of fewer floods. More profound effects have occurred in Reaches 3 and 5 downstream of the Cougar and Blue River Dams, respectively; large floods have been eliminated in these reaches. Streamflows have decreased from February to

Table 10. Significant changes to environmental flow components in the McKenzie River basin as a result of upstream dams.

[Reaches 8 and 10 were not evaluated for changes because of the Leaburg and Walterville canal diversions, respectively]

\begin{tabular}{|c|c|c|c|c|c|c|}
\hline $\begin{array}{c}\text { Reach } \\
\text { No. }\end{array}$ & Large floods & Small floods & High flows & Low flows & Extremely low flows & Monthly distribution \\
\hline 1 & Less frequent & Less frequent & $\begin{array}{l}\text { No significant } \\
\text { change }\end{array}$ & $\begin{array}{l}\text { No significant } \\
\text { change }\end{array}$ & No significant change & No significant change \\
\hline 2 & $\begin{array}{l}\text { No significant } \\
\text { change }\end{array}$ & $\begin{array}{l}\text { No significant } \\
\text { change }\end{array}$ & $\begin{array}{l}\text { No significant } \\
\text { change }\end{array}$ & $\begin{array}{l}\text { No significant } \\
\text { change }\end{array}$ & No significant change & No significant change \\
\hline 3 & Eliminated & $\begin{array}{l}\text { Decreased } \\
\text { magnitude, } \\
\text { less frequent }\end{array}$ & $\begin{array}{l}\text { Decreased } \\
\text { magnitude }\end{array}$ & $\begin{array}{l}\text { Increased } \\
\text { magnitude }\end{array}$ & $\begin{array}{l}\text { Increased magnitude, } \\
\text { shift in timing from } \\
\text { September to March }\end{array}$ & $\begin{array}{l}\text { Decreased streamflow } \\
\text { from February to May, } \\
\text { increased streamflow } \\
\text { from July to November }\end{array}$ \\
\hline 4 & $\begin{array}{l}\text { Decreased } \\
\text { magnitude }\end{array}$ & $\begin{array}{l}\text { Decreased } \\
\text { magnitude }\end{array}$ & $\begin{array}{l}\text { No significant } \\
\text { change }\end{array}$ & $\begin{array}{l}\text { Increased } \\
\text { magnitude }\end{array}$ & $\begin{array}{l}\text { Increased magnitude, } \\
\text { no significant change } \\
\text { in timing. }\end{array}$ & $\begin{array}{l}\text { Decreased streamflow } \\
\text { from February to May, } \\
\text { increased streamflow } \\
\text { from August to November }\end{array}$ \\
\hline 5 & Eliminated & Eliminated & $\begin{array}{l}\text { No significant } \\
\text { change }\end{array}$ & $\begin{array}{l}\text { Increased } \\
\text { magnitude }\end{array}$ & $\begin{array}{l}\text { Increased magnitude, } \\
\text { shift in timing from } \\
\text { September to March }\end{array}$ & $\begin{array}{l}\text { Decreased streamflow } \\
\text { from February to May, } \\
\text { increased streamflow } \\
\text { from July to November }\end{array}$ \\
\hline 6,7 & $\begin{array}{l}\text { Decreased } \\
\text { magnitude, } \\
\text { less frequent }\end{array}$ & $\begin{array}{l}\text { Decreased } \\
\text { magnitude, } \\
\text { less frequent }\end{array}$ & $\begin{array}{l}\text { No significant } \\
\text { change }\end{array}$ & $\begin{array}{l}\text { Increased } \\
\text { magnitude }\end{array}$ & $\begin{array}{l}\text { Increased magnitude, } \\
\text { no significant change } \\
\text { in timing. }\end{array}$ & $\begin{array}{l}\text { Decreased streamflow from } \\
\text { March to May, increased } \\
\text { streamflow from July to } \\
\text { November }\end{array}$ \\
\hline $9,11,12$ & $\begin{array}{l}\text { Decreased } \\
\text { magnitude, } \\
\text { less frequent }\end{array}$ & $\begin{array}{l}\text { Decreased } \\
\text { magnitude, } \\
\text { less frequent }\end{array}$ & $\begin{array}{l}\text { No significant } \\
\text { change }\end{array}$ & $\begin{array}{l}\text { Increased } \\
\text { magnitude }\end{array}$ & $\begin{array}{l}\text { Increased magnitude, } \\
\text { no significant change } \\
\text { in timing. }\end{array}$ & $\begin{array}{l}\text { Decreased streamflow from } \\
\text { March to May, increased } \\
\text { streamflow from July to } \\
\text { November }\end{array}$ \\
\hline
\end{tabular}


May, and increased from July to November. The hydrologic alterations created by the upper basin dams have propagated downstream to the Willamette River confluence; however, they are less pronounced in each consecutive downstream reach.

The effect of the dams on the magnitude and frequency of major floods in Reach 7 can be seen in the streamflow record of the McKenzie River near Vida streamflow-gaging station (14162500), which has been in operation since 1924 (fig. 7). Since the early 1960s, the dams have effectively kept most floods below the bankfull streamflow at the Vida gaging station of $20,000 \mathrm{ft}^{3} / \mathrm{s}$. Without the dams, the USACE estimated that the maximum daily mean streamflow of the floods of December 1964 and February 1996 would have been 62,338 and 47,622 $\mathrm{ft}^{3} / \mathrm{s}$, respectively.

Monthly precipitation data at the Eugene airport from the pre- and post-dam periods, water years 1936-1962 and 1963-2008, were evaluated to determine whether climate was a contributing factor to changes in streamflow and not just the effects of dams. Based on a Wilcox rank-sum test, there was no significant difference in monthly precipitation between the two periods. The p-values for all months, with the exception of November, were greater than 0.05 (table 11).
Table 11. Airport median monthly precipitation totals, Eugene, Oregon, 1936-1962 and 1963-2008.

[p-value less than 0.05 indicate there is a significant difference in the monthly precipitation totals between the pre-dam and post-dam periods. Data from 1936-39 measured at Eugene station (352706) and from 1940-2009 measured at Eugene Airport station (352709)]

\begin{tabular}{lccc}
\hline \multirow{2}{*}{ Months } & \multicolumn{2}{c}{ Precipitation (inches) } & \\
\cline { 2 - 3 } & $\begin{array}{c}\text { Pre-dam } \\
\mathbf{1 9 3 6 - 1 9 6 2}\end{array}$ & $\begin{array}{c}\text { Post-dam } \\
\mathbf{1 9 6 3 - 2 0 0 8}\end{array}$ & \\
\hline January & 5.04 & 7.53 & 0.20 \\
February & 5.29 & 4.53 & .18 \\
March & 4.12 & 4.78 & .29 \\
April & 2.33 & 2.69 & .08 \\
May & 2.18 & 2.14 & .90 \\
June & 1.18 & 1.03 & .89 \\
July & .12 & .32 & .13 \\
August & .41 & .44 & .31 \\
September & 1.01 & 1.13 & .75 \\
October & 2.90 & 2.95 & .62 \\
November & 5.81 & 7.43 & .04 \\
December & 4.94 & 7.68 & .08 \\
\hline
\end{tabular}

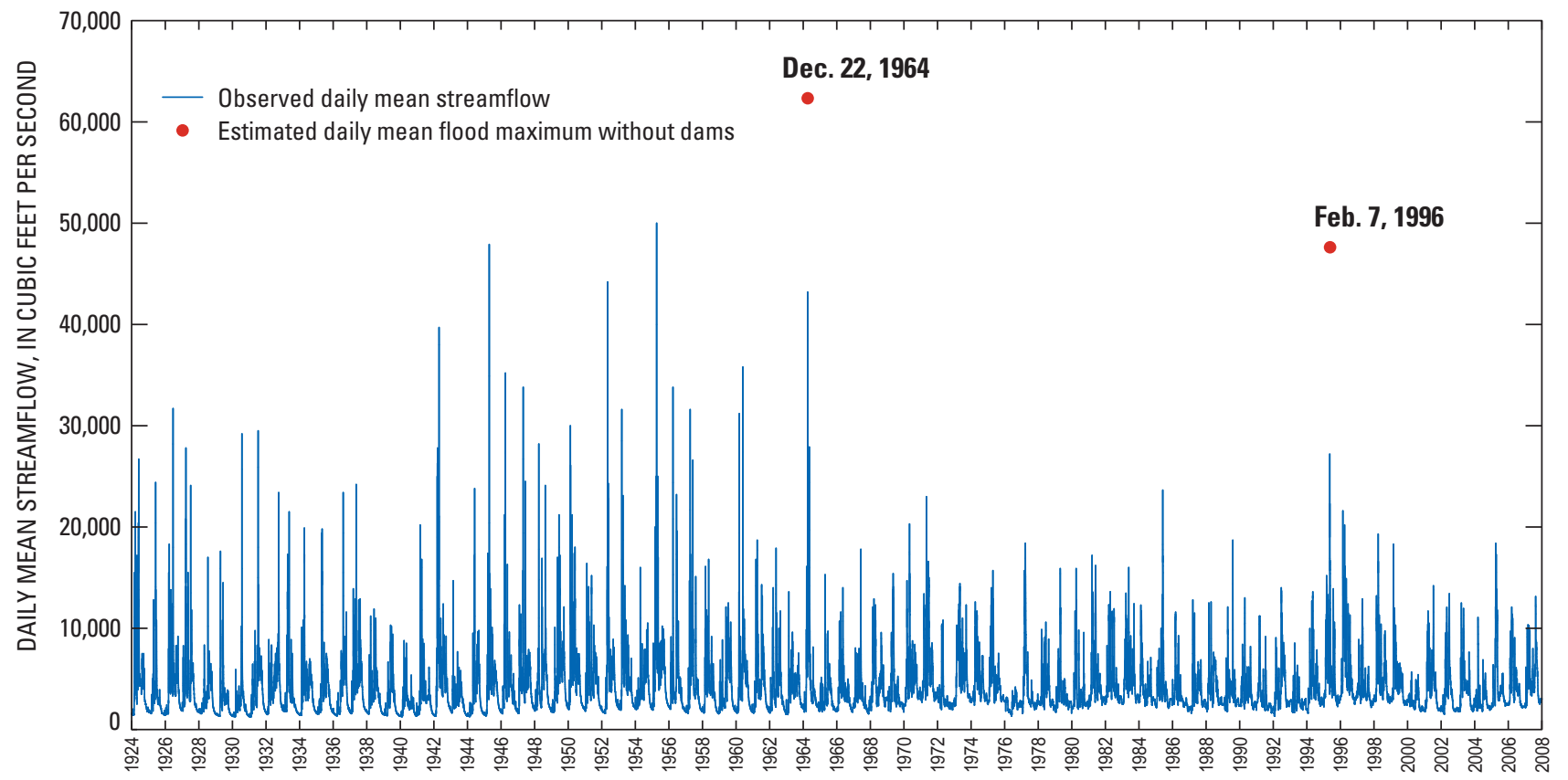

Figure 7. Daily mean streamflow in Reach 7 at McKenzie River near Vida, Oregon (14162500), water years $1925-2008$. 


\section{McKenzie River-Reach 1}

Mean daily streamflow data for pre- and post-dam periods (water years 1936-62 and 1963-2008) from the streamflow-gaging station at McKenzie River below Trail Bridge Dam, near Belknap Springs, Oregon (14158850), show that December streamflows slightly decreased and that January and March streamflows slightly increased in the post-dam period (fig. 8). Overall the effect of the Carmen-SmithTrail Bridge dam complex was a modulation of the annual hydrograph. This also is evident in a comparison of water year 1995 measured regulated and computed unregulated daily mean streamflows (fig. 9). Although the timing of streamflow events remained constant, the magnitude of the high-flow events decreased and their streamflow recessions were elevated under regulated conditions. Summer streamflow for water year 1995 was greater under regulated conditions. These hydrologic effects are consistent with the operation of the Carmen-Smith-Trail Bridge Dam complex, which was constructed uniquely for hydropower production and has minimal total reservoir storage.

Downstream of the McKenzie River below Trail Bridge, near Belknap Springs, Oregon, streamflow-gaging station (14158850), the McKenzie River at McKenzie Bridge streamflow-gaging station (14159000), near the lower end of Reach 1, was in operation during water years 1911-94. Post-dam period (water years 1963-94) 2-, 10-, 50-, and 100-year peak streamflows, computed using the Bulletin 17B
Log Pearson III method, were slightly (less than 10 percent) less than corresponding peak streamflows for the pre-dam period (water years 1911-62) (table 12). (It was not possible to compute peak streamflows for the for the gaging station at McKenzie River below Trail Bridge, near Belknap Springs, gaging station (14158850) because data collection began in water year 1960, which was only 3 years prior to the construction of the Carmen-Smith-Trail Bridge Dam complex (table 6). It was only possible to extend daily streamflows for this record and not annual peak streamflows.)

At the streamflow-gaging station below Trail Bridge Dam (14158850), the medians of the annual 1-day maximum and 7-day minimum streamflows for the post-dam period are slightly lower than during the pre-dam period (table 13). However, the IHA "significance count" p-values for both metrics were greater than 0.05 , and the difference was not statistically significant. The median monthly streamflows from both periods show minor differences without a consistent pattern of increase or decrease (table 14). The differences were all statistically insignificant with the exception of January. Changes in the 10th, 50th, and 90th percent streamflow exceedances between the pre- and post-dam periods also were relatively minor (table 15). However, the frequency of large (10-year or greater) flood events (based on daily mean streamflow and not annual peak streamflow data) decreased during the post-dam period by 71 percent (table 15).

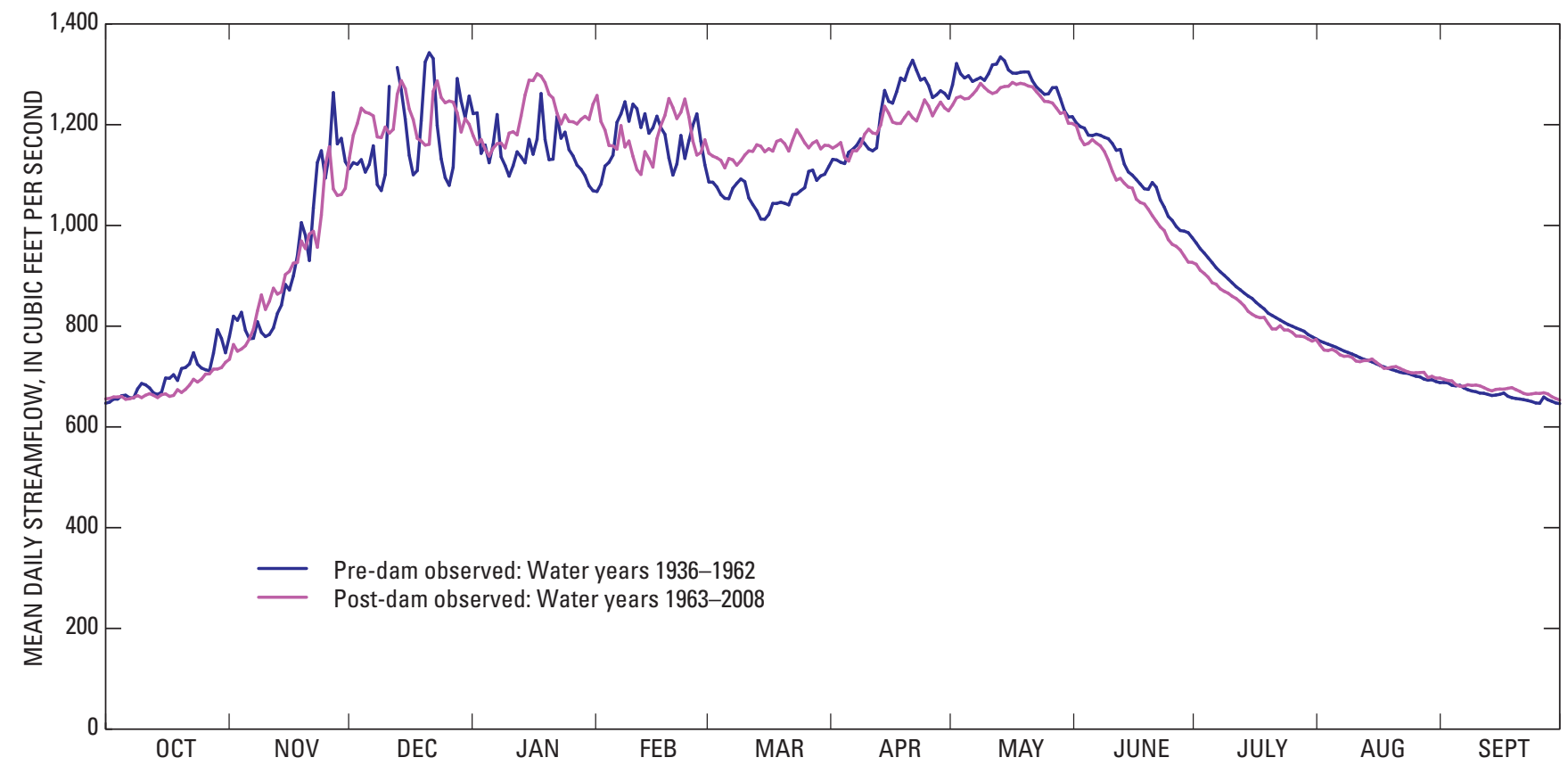

Figure 8. Mean daily streamflow in Reach 1 at McKenzie River below Trail Bridge Dam, near Belknap Springs, Oregon (14158850), water years 1936-62 and 1963-2008. 


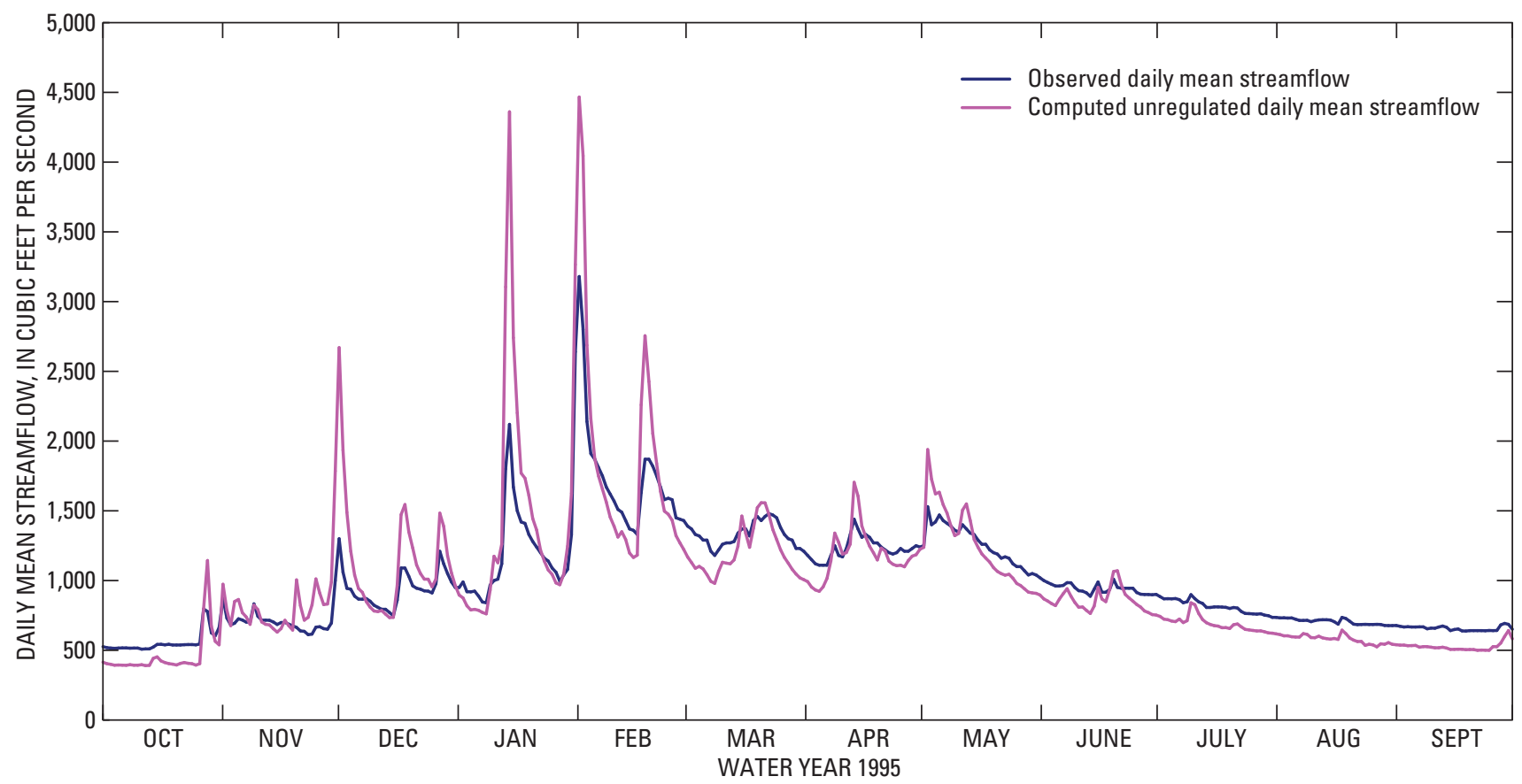

Figure 9. Daily mean streamflow in Reach 1 at McKenzie River below Trail Bridge Dam, near Belknap Springs, Oregon (14158850), water year 1995.

Table 12. Pre- and post-dam flood statistics for McKenzie River, Oregon.

[Flood statistics computed from annual peak streamflow data based on the Bulletin 17B Log Pearson III method (Interagency Advisory Committee on Water Data (1981). Abbreviation: $\mathrm{ft}^{3} / \mathrm{s}$, cubic feet per second]

\begin{tabular}{|c|c|c|c|c|c|c|c|}
\hline \multirow[b]{2}{*}{$\begin{array}{c}\text { Streamflow- } \\
\text { gaging } \\
\text { station No. }\end{array}$} & \multirow[b]{2}{*}{$\begin{array}{l}\text { Streamflow-gaging station description } \\
\text { and study reach No. }\end{array}$} & \multirow[b]{2}{*}{$\begin{array}{l}\text { Recurrence } \\
\text { interval } \\
\text { (years) }\end{array}$} & \multicolumn{2}{|c|}{ Pre-dam period } & \multicolumn{2}{|c|}{ Post-dam period } & \multirow[b]{2}{*}{$\begin{array}{l}\text { Percent } \\
\text { change }\end{array}$} \\
\hline & & & $\begin{array}{c}\text { Period of } \\
\text { record } \\
\text { (water years) }\end{array}$ & $\begin{array}{c}\text { Streamflow } \\
\quad\left(\mathrm{ft}^{3} / \mathrm{s}\right)\end{array}$ & $\begin{array}{c}\text { Period of } \\
\text { record } \\
\text { (water years) }\end{array}$ & $\begin{array}{l}\text { Streamflow } \\
\quad\left(\mathrm{ft}^{3} / \mathrm{s}\right)\end{array}$ & \\
\hline \multirow{4}{*}{14159000} & McKenzie River at McKenzie Bridge & 2 & $1911-62$ & 6,392 & 1963-94 & 6,231 & -2.5 \\
\hline & Reach 1 & 10 & & 11,380 & & 10,500 & -7.7 \\
\hline & & 50 & & 16,060 & & 15,090 & -6.0 \\
\hline & & 100 & & 18,120 & & 17,290 & -4.6 \\
\hline \multirow[t]{4}{*}{14159500} & $\begin{array}{l}\text { South Fork McKenzie River near } \\
\text { Rainbow }\end{array}$ & 2 & $1946-63$ & 9,242 & $1964-2008$ & 4,262 & -54 \\
\hline & Reach 3 & 10 & & 19,070 & & 6,506 & -66 \\
\hline & & 50 & & 29,510 & & 7,946 & -73 \\
\hline & & 100 & & 34,430 & & 8,451 & -75 \\
\hline \multirow[t]{4}{*}{14162200} & Blue River at Blue River & 2 & ${ }^{1} 1936-65$ & 5,869 & 1969-2008 & 3,272 & -44 \\
\hline & Reach 5 & 10 & & 11,110 & & 4,071 & -63 \\
\hline & & 50 & & 16,790 & & 4,525 & -73 \\
\hline & & 100 & & 19,520 & & 4,677 & -76 \\
\hline \multirow{4}{*}{14162500} & McKenzie River near Vida & 2 & $1925-62$ & 28,740 & $1963-2008$ & 17,210 & -40 \\
\hline & Reach 7 & 10 & & 40,320 & & 27,400 & -32 \\
\hline & & 50 & & 63,510 & & 37,060 & -42 \\
\hline & & 100 & & 69,970 & & 41,390 & -41 \\
\hline
\end{tabular}

${ }^{1}$ Annual peak streamflow data from the pre-dam flow gage: 14162000 . 
Table 13. Pre- and post-dam streamflow statistics from measured and estimated daily mean streamflow for McKenzie River, Oregon.

[1-day max.: Median of 1-day maximum annual flows; 7-day min.: Median of 7-day averaged minimum annual flows. Indicators of Hydrologic Alteration (IHA) significance count value: Output from the IHA software package and is equivalent to a p value for significance. Reaches 8 and 10 statistics computed from Leaburg and Walterville canal bypass river flow data only. Pre-dam period data were unavailable for Reaches 8 and 10. Abbreviations: na, not available; Unreg, statistics based computed unregulated daily flows from the U.S. Army Corps of Engineers; Reg, statistics based on simulated regulated daily flows from the U.S. Army Corps of Engineers; na, not applicable]

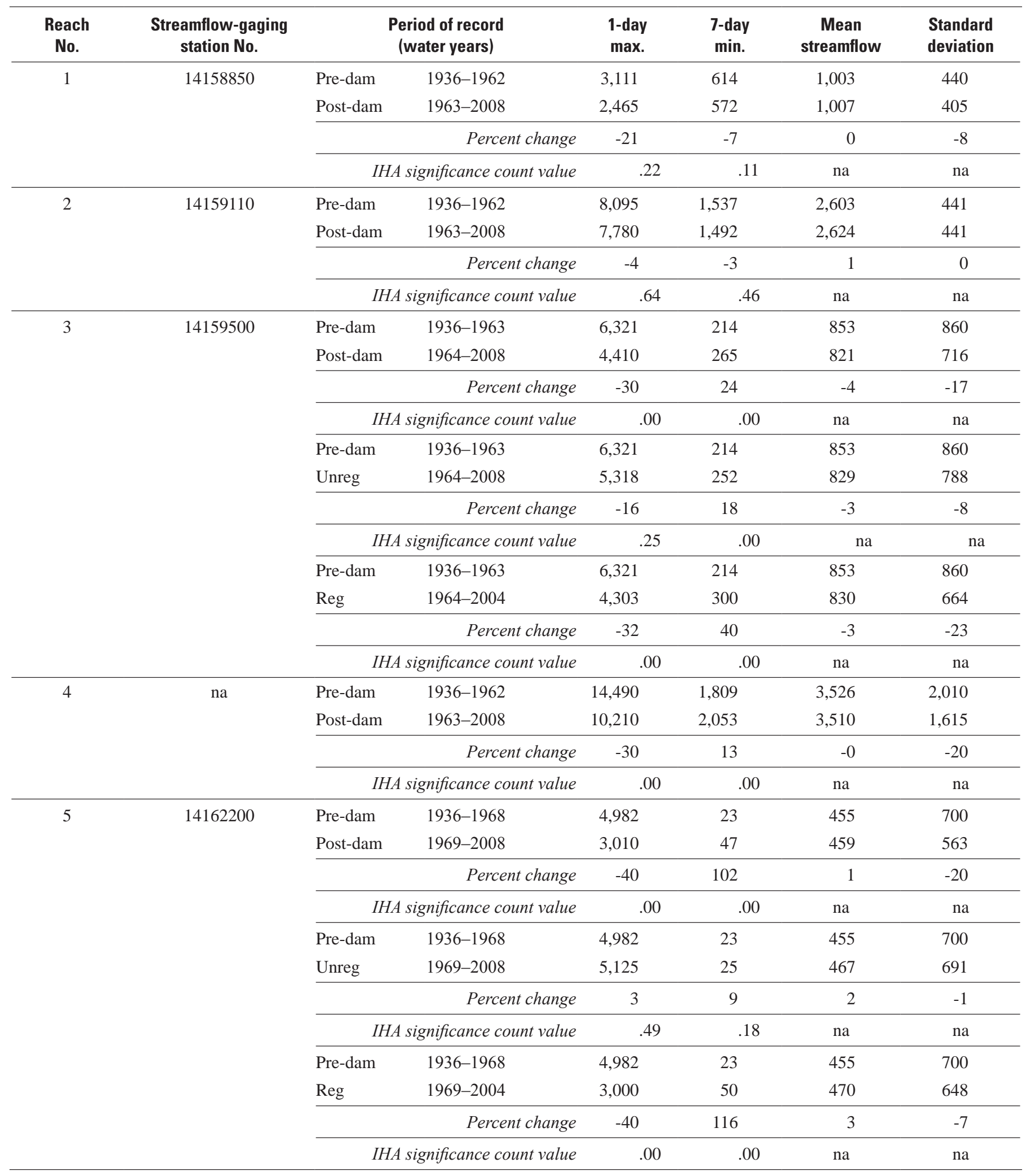


Table 13. Pre- and post-dam streamflow statistics from measured and estimated daily mean streamflow for McKenzie River, Oregon.Continued

[1-day max.: Median of 1-day maximum annual flows; 7-day min.: Median of 7-day averaged minimum annual flows. Indicators of Hydrologic Alteration (IHA) significance count value: Output from the IHA software package and is equivalent to a p value for significance. Reaches 8 and 10 statistics computed from Leaburg and Walterville canal bypass river flow data only. Pre-dam period data were unavailable for Reaches 8 and 10. Abbreviations: na, not available; Unreg, statistics based computed unregulated daily flows from the U.S. Army Corps of Engineers; Reg, statistics based on simulated regulated daily flows from the U.S. Army Corps of Engineers]

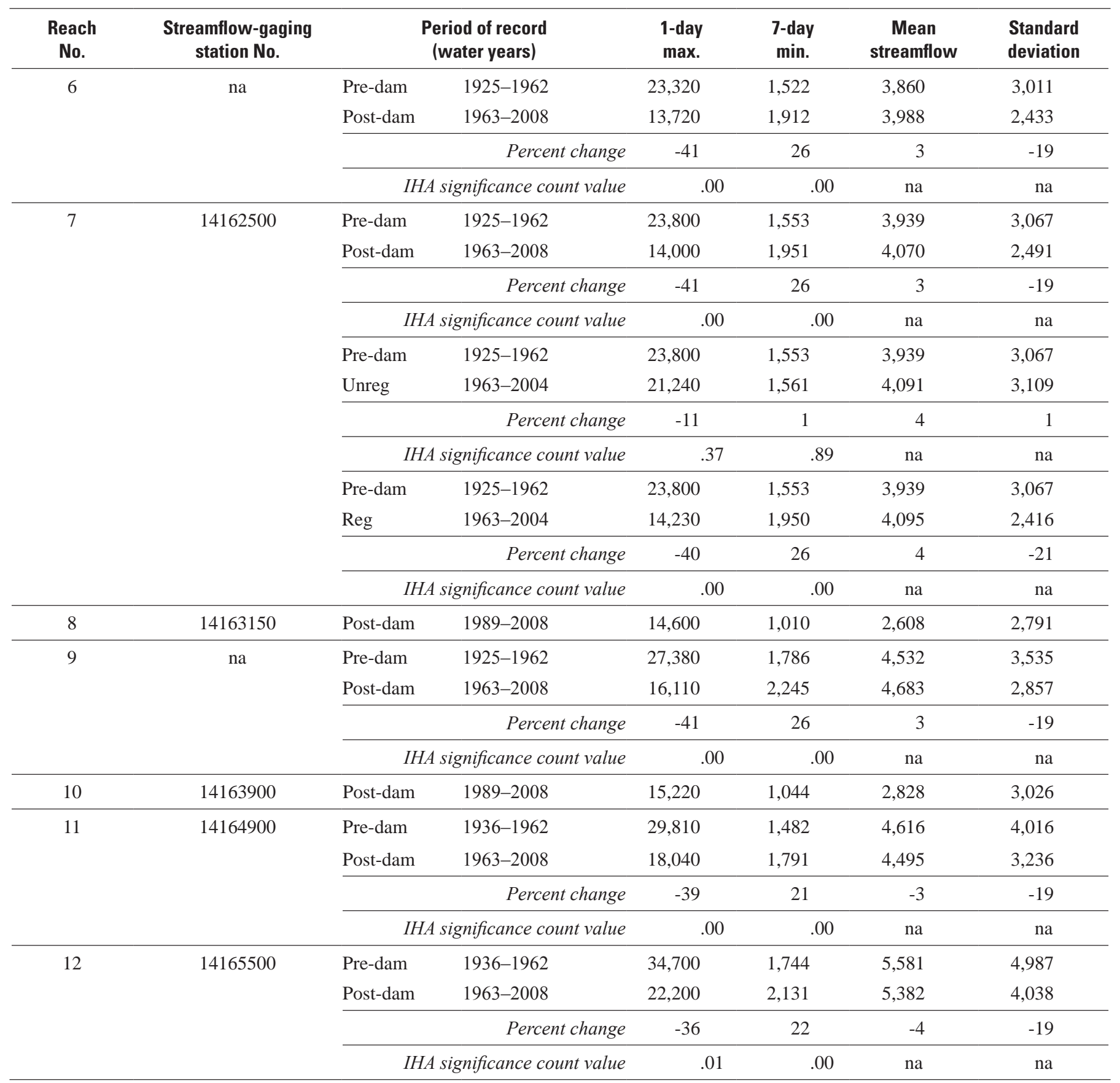




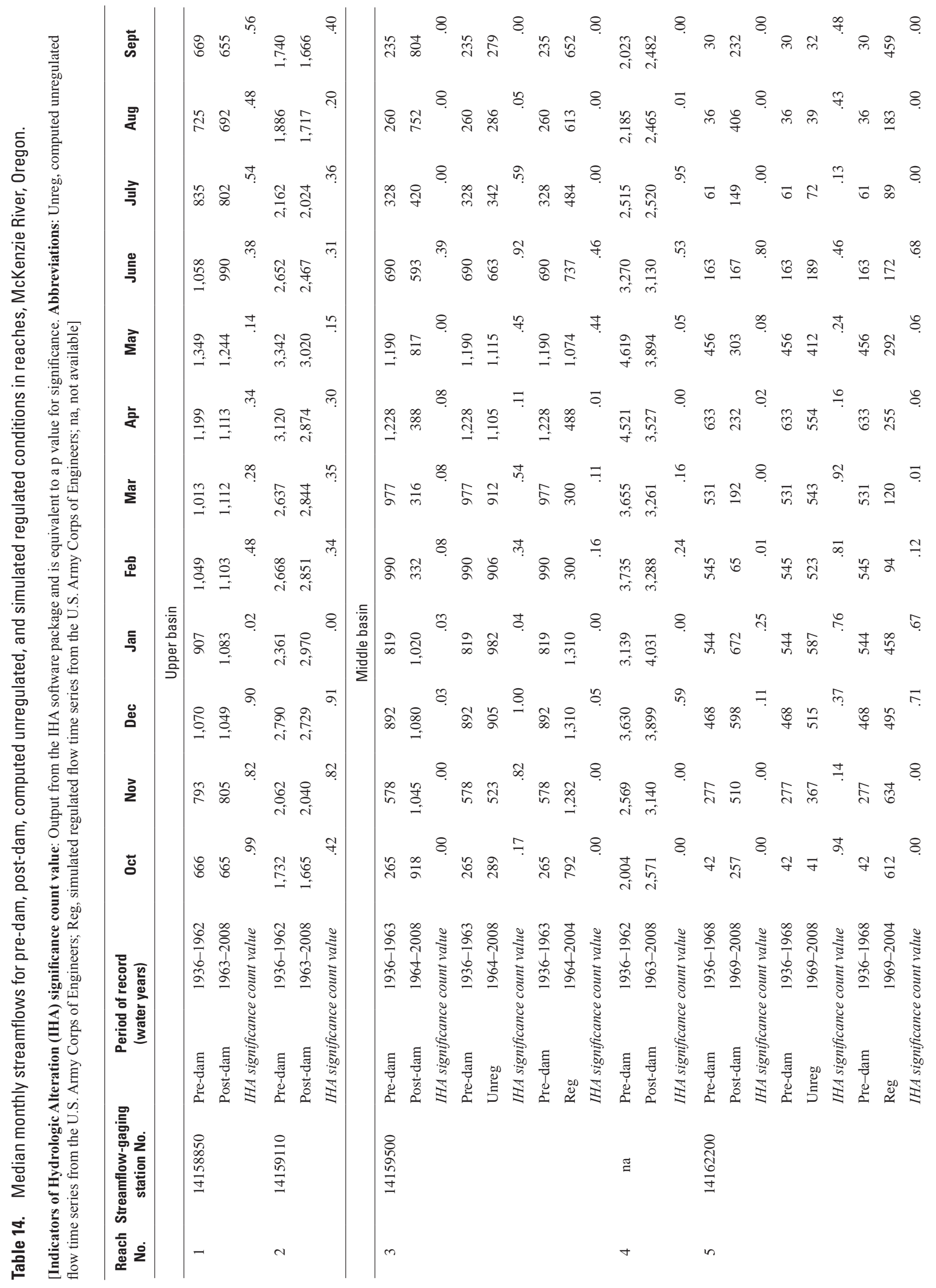




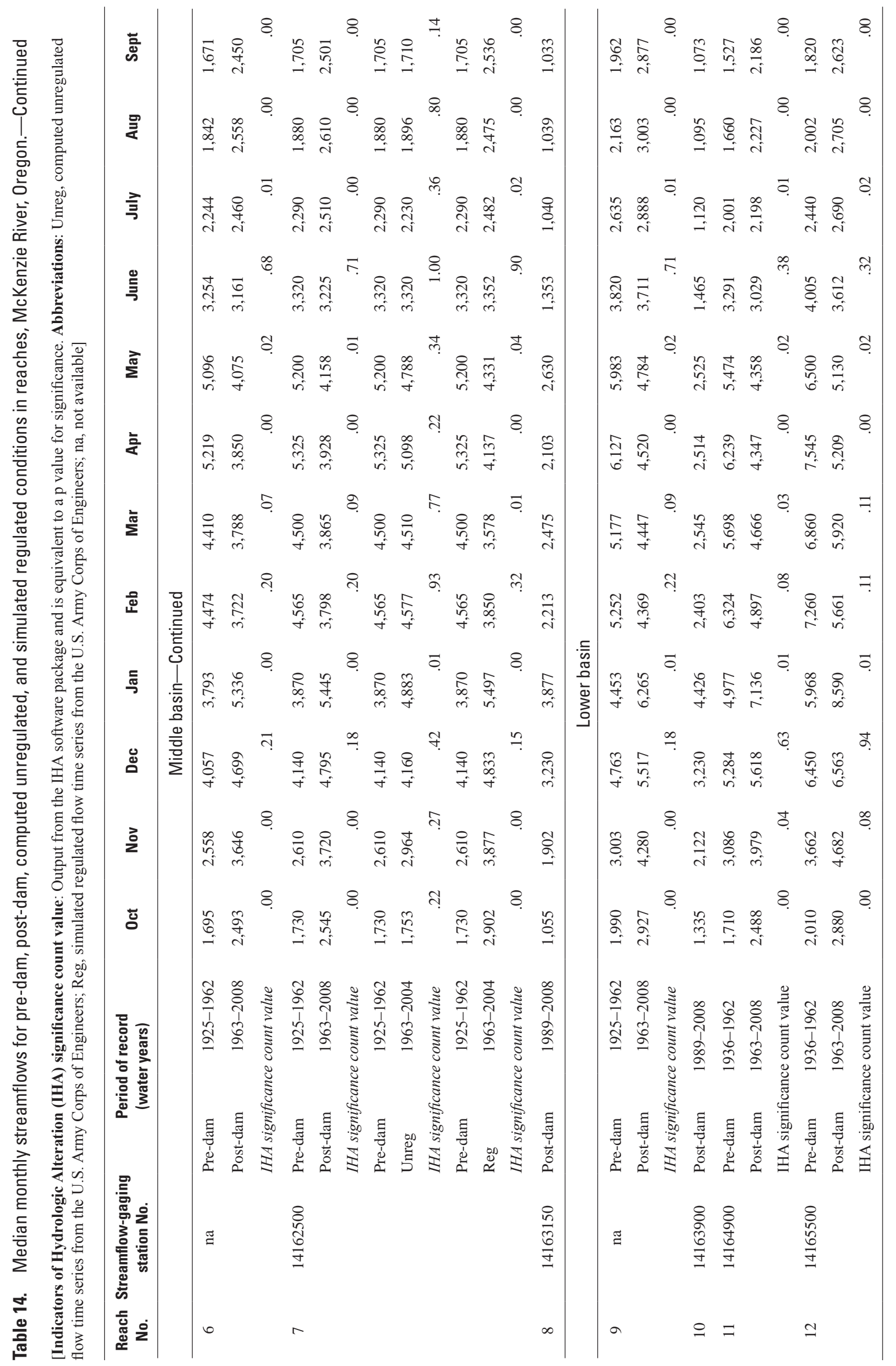


Table 15. Hydrologic changes in selected reaches, McKenzie River, Oregon.

[Pre- and post-dam period of records are in water years. Recurrence intervals for the small and large floods are 2 and 10 years, respectively, and based on daily mean, not annual peak streamflow data]

\begin{tabular}{|c|c|c|c|}
\hline & $\begin{array}{l}\text { Pre-dam } \\
1936-1962\end{array}$ & $\begin{array}{l}\text { Post-dam } \\
1963-2008\end{array}$ & $\begin{array}{c}\text { Percentage } \\
\text { change }\end{array}$ \\
\hline \multicolumn{4}{|c|}{ Reach 1 below Trail Bridge Dam at McKenzie River near Belknap Springs (14158850) } \\
\hline Number of years in period & 27 & 46 & \\
\hline \multicolumn{4}{|l|}{ Percent streamflow exceedance, in cubic feet per second } \\
\hline 10th & 1,520 & 1,509 & -0.7 \\
\hline 50th & 884 & 916 & 3.6 \\
\hline 90th & 601 & 622 & 3.5 \\
\hline 10th/50th & 1.72 & 1.65 & -4.2 \\
\hline Median Julian date of the annual minimum daily streamflow & 281 & 284 & \\
\hline Percent of years having one or more small floods per year & 44 & 37 & -17 \\
\hline Percent of years having two or more small floods per year & 15 & 2.2 & -85 \\
\hline Percent of years having one or more large floods per year & 7.4 & 2.2 & -71 \\
\hline Median of the large-flood magnitudes, in cubic feet per second & 6,540 & 7,650 & 17 \\
\hline \multicolumn{4}{|c|}{ Reach 3 below Cougar Dam at South Fork McKenzie River, near Rainbow (14159500) } \\
\hline Number of years in period & 28 & 45 & \\
\hline \multicolumn{4}{|l|}{ Percent streamflow exceedance, in cubic feet per second } \\
\hline 10th & 1,700 & 1,430 & -16 \\
\hline 50th & 604 & 705 & 17 \\
\hline 90th & 235 & 277 & 18 \\
\hline 10th/50th & 2.81 & 2.03 & -28 \\
\hline Median Julian date of the annual minimum daily streamflow & 275 & 64 & \\
\hline Percent of years having one or more small floods per year & 46 & 4.4 & -90 \\
\hline Percent of years having two or more small floods per year & 7.1 & .0 & -100 \\
\hline Percent of years having one or more large floods per year & 7.1 & .0 & -100 \\
\hline Median of the large-flood magnitudes, in cubic feet per second & 13,950 & 0 & -100 \\
\hline \multicolumn{4}{|c|}{ Reach 5 below Blue River Dam, at Blue River, near Blue River (14162200) } \\
\hline Number of years in period & 33 & 40 & \\
\hline \multicolumn{4}{|l|}{ Percent streamflow exceedance, in cubic feet per second } \\
\hline 10th & 1,044 & 1,006 & -3.6 \\
\hline 50 th & 256 & 294 & 15 \\
\hline 90th & 32 & 51 & 59 \\
\hline 10th/50th & 4.08 & 3.42 & -16 \\
\hline Median Julian date of the annual minimum daily streamflow & 271 & 52.5 & \\
\hline Percent of years having one or more small floods per year & 45 & 0 & -100 \\
\hline Percent of years having two or more small floods per year & 12 & 0 & -100 \\
\hline Percent of years having one or more large floods per year & 9.1 & 0 & -100 \\
\hline Median of the large-flood magnitudes, in cubic feet per second & 12,690 & 0 & -100 \\
\hline
\end{tabular}


Table 15. Hydrologic changes in selected reaches, McKenzie River-—Continued

[Pre- and post-dam period of records are in water years. Recurrence intervals for the small and large floods are 2 and 10 years, respectively, and based on daily mean, not annual peak streamflow data]

\begin{tabular}{|c|c|c|c|}
\hline & $\begin{array}{l}\text { Pre-dam } \\
1936-1962\end{array}$ & $\begin{array}{l}\text { Post-dam } \\
\text { 1963-2008 }\end{array}$ & $\begin{array}{c}\text { Percentage } \\
\text { change }\end{array}$ \\
\hline \multicolumn{4}{|c|}{ Reach 7 at McKenzie River near Vida (14162500) } \\
\hline Number of years in period & 39 & 46 & \\
\hline \multicolumn{4}{|l|}{ Percent streamflow exceedance, in cubic feet per second } \\
\hline 10th & 7,000 & 6,970 & -0.4 \\
\hline 50th & 3,030 & 3,230 & 6.6 \\
\hline 90th & 1,600 & 2,167 & 35 \\
\hline 10th/50th & 2.31 & 2.16 & -6.6 \\
\hline Median Julian date of the annual minimum daily streamflow & 276 & 282 & \\
\hline Percent of years having one or more small floods per year & 44 & 2.2 & -95 \\
\hline Percent of years having two or more small floods per year & 13 & 0.0 & -100 \\
\hline Percent of years having one or more large floods per year & 7.7 & 2.2 & -72 \\
\hline Median of the large-flood magnitudes, in cubic feet per second & 47,900 & 43,200 & -10 \\
\hline \multicolumn{4}{|c|}{ Reach 12 at McKenzie River near Coburg (14165500) } \\
\hline Number of years in period & 27 & 46 & \\
\hline \multicolumn{4}{|l|}{ Percent streamflow exceedance, in cubic feet per second } \\
\hline 10th & 10,500 & 9,860 & -6.1 \\
\hline 50th & 4,304 & 4,096 & -4.8 \\
\hline 90th & 1,820 & 2,390 & 31 \\
\hline 10th/50th & 2.44 & 2.41 & -1.3 \\
\hline Median Julian date of the annual minimum daily streamflow & 274 & 259 & \\
\hline Percent of years having one or more small floods per year & 44 & 11 & -76 \\
\hline Percent of years having two or more small floods per year & 15 & 0 & -100 \\
\hline Percent of years having one or more large floods per year & 7.4 & 2.2 & -71 \\
\hline Median of the large-flood magnitudes, in cubic feet per second & 67,400 & 83,100 & 23 \\
\hline
\end{tabular}




\section{South Fork McKenzie River-Reach 3}

Constructed in the early 1960s, Cougar Dam has reduced the magnitude of flood events, increased summer and early fall low flows in the South Fork McKenzie River (Reach 3), and changed the annual distribution of streamflow (figs. 10 and 11). Although December and January mean daily streamflows appear relatively unaffected, streamflows from February to May decreased as water is stored in the reservoir for summer releases. The date of the annual minimum streamflow shifted from August and September to March, April, and July. Daily streamflow releases from Cougar Dam for water year 1995 also show abrupt rises and falls that do not follow unregulated streamflow conditions (fig. 11).

For the pre-dam period (water years 1946-63), the 100 -year flood magnitude was $34,430 \mathrm{ft}^{3} / \mathrm{s}$; however, for the post-dam period (water years 1964-2008), it decreased by 75 percent to $8,451 \mathrm{ft}^{3} / \mathrm{s}$ (table 12). The median of the annual 1-day maximum daily streamflows decreased from 6,321 to $4,410 \mathrm{ft}^{3} / \mathrm{s}$, a difference that is statistically significant (table 13). On a monthly basis, there was a near-significant ( 0.08 or less) decrease in streamflows from February to May and a significant increase from August to November (table 14). High flows (10th percent streamflow exceedance) decreased by 16 percent and low flows (90th percent streamflow exceedance) increased by 18 percent (table 15). The frequency of small floods (5-10 year recurrence interval) decreased by 90 percent and large floods (greater than 10-year recurrence interval) were eliminated. The median of the annual 7-day minimum daily mean streamflows increased from 214 to $265 \mathrm{ft}^{3} / \mathrm{s}$ (table 13), a difference that is statistically significant.

The medians of almost all monthly streamflows and 1-day annual maximum streamflow (but not the annual 7-day minimum streamflow) computed from the USACE computed unregulated streamflow data for the post-dam period (water years 1964-2008) were not significantly different from the pre-dam period (water years 1936-1963) medians (tables 13 and 14). This, along with the lack of significant difference in the pre- and post-dam period monthly precipitation data from the Eugene airport (table 11), indicate that climate is less of a factor than the dams in explaining the significant difference between the pre- and post-dam period observed streamflow data medians.

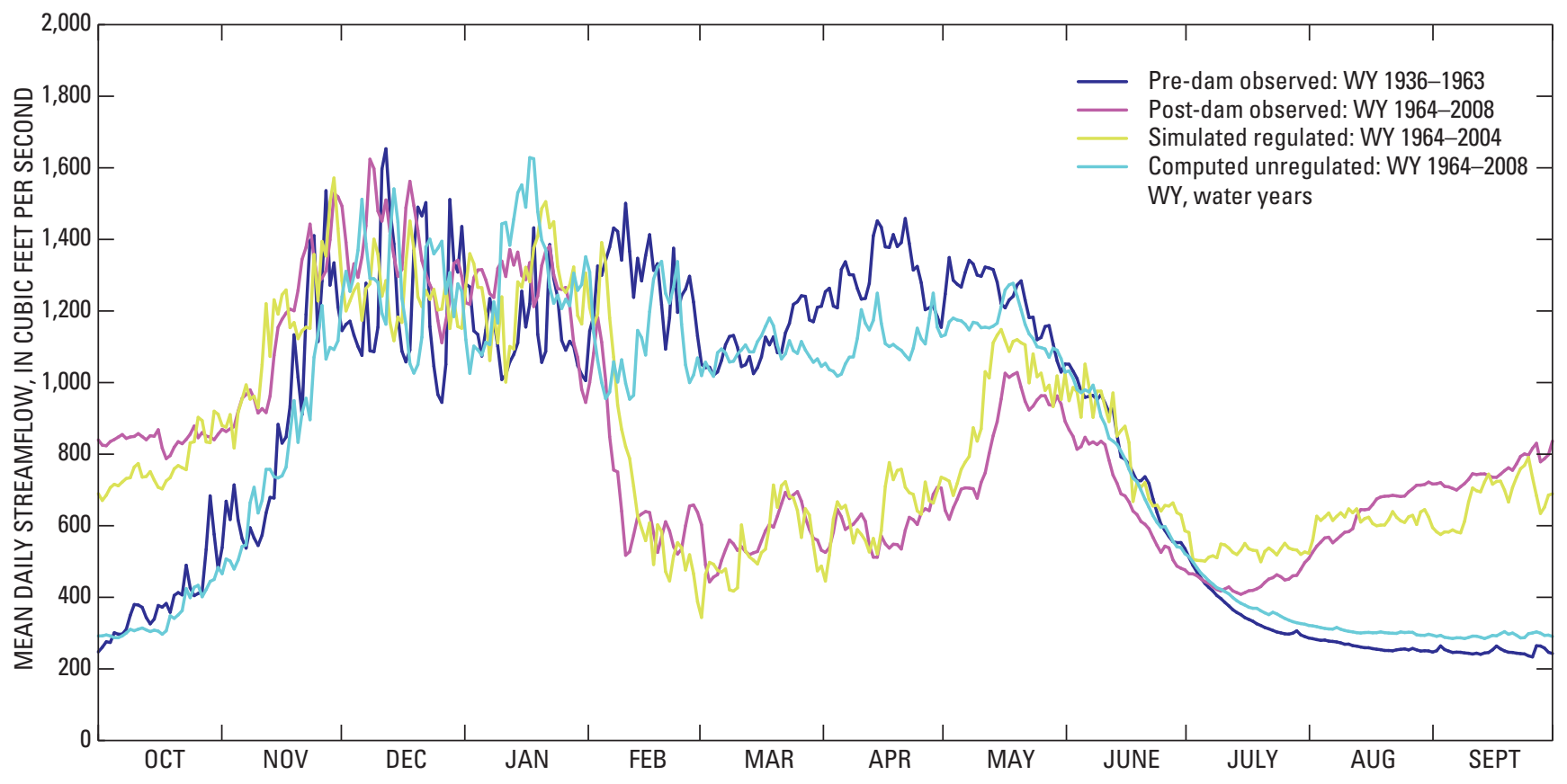

Figure 10. Mean daily streamflow in Reach 3 below Cougar Dam at South Fork McKenzie River, near Rainbow, Oregon (14159500). 


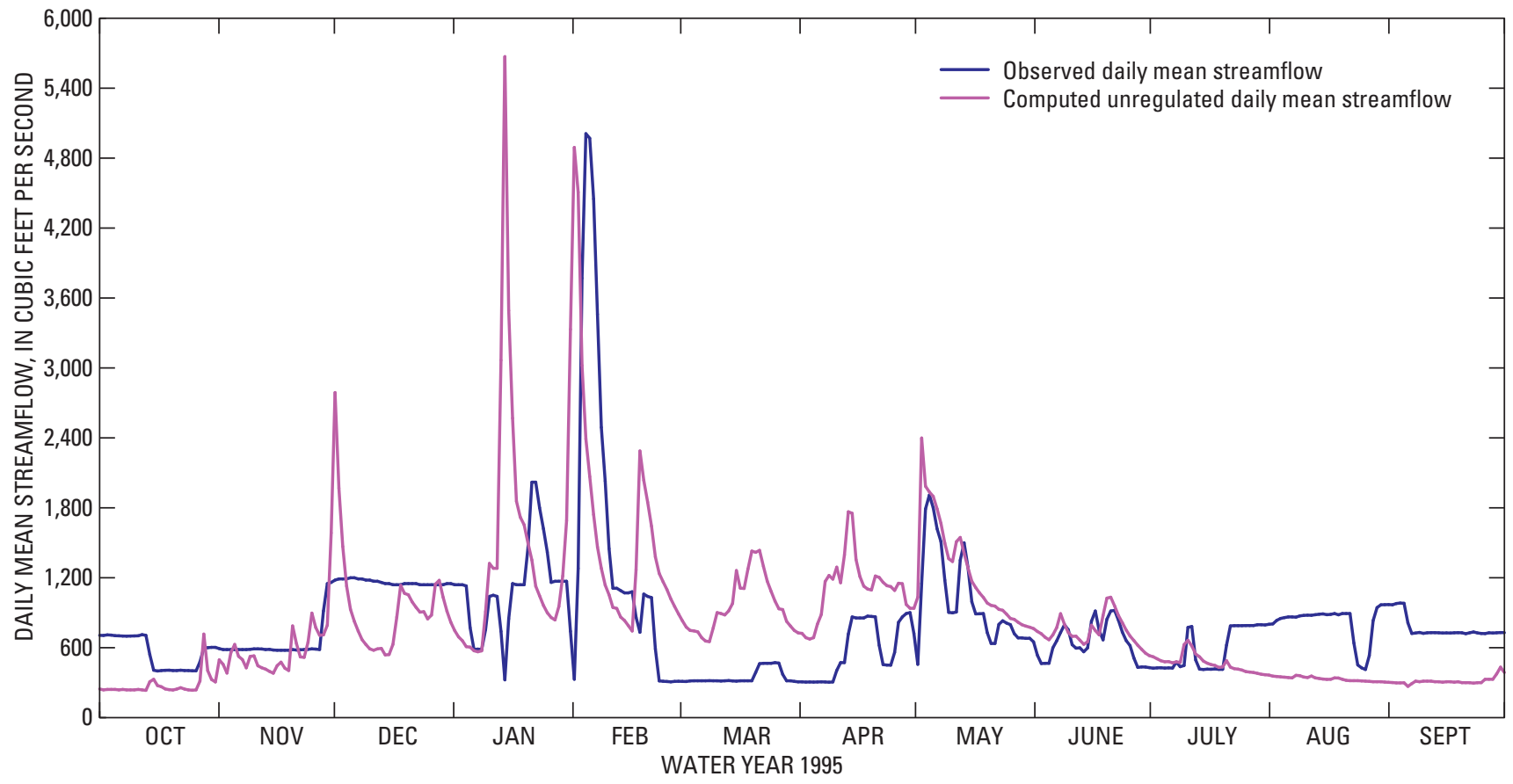

Figure 11. Daily mean streamflow in Reach 3 below Cougar Dam at South Fork McKenzie River, near Rainbow, Oregon (14159500), water year 1995. 


\section{Blue River-Reach 5}

Reach 5 extends from the Blue River Dam, completed in 1968, to the confluence with the South Fork McKenzie River. Like Cougar Dam, Blue River Dam is used for flood control in addition to other purposes (although not hydropower). Mean streamflow for Blue River is approximately one-half the mean streamflow for South Fork McKenzie River. Like Cougar Dam, Blue River Dam has a similar effect on the annual distribution of daily streamflows (fig. 12). Streamflows decreased in the spring and increased from the summer through the fall. Streamflow releases from Blue River Dam in water year 1995 also have abrupt rises and falls that are in contrast to the computed unregulated daily streamflow hydrograph (fig. 13). The 100-year flood magnitude for the pre-dam period (water years 1936-65) was 19,520 ft³.s. However, the 100-year flood magnitude for the post-dam period (water years 1969-2008) decreased by 76 percent to 4,677 $\mathrm{ft}^{3} / \mathrm{s}$ (table 12). Small and large floods, defined by the pre-dam period data, have been eliminated since the dam was constructed (table 15). Similar to the pre- and post-dam changes in median monthly streamflows in the South Fork McKenzie River (Reach 3), there was a significant decrease and significant increase in streamflows from February to April and July to November, respectively (table 14). The median of the annual 1-day maximum daily streamflows decreased from 4,982 to 3,010 $\mathrm{ft}^{3} / \mathrm{s}$, and the median of the annual 7-day minimum daily streamflows increased from 23 to $47 \mathrm{ft}^{3} / \mathrm{s}$ (table 13). The pre- and post-dam period difference for both these metrics was significant. Changes in median to high streamflows (10th and 50th percent streamflow exceedances) between the pre- and post-dam periods were relatively minor. However, the 90th percent streamflow exceedance significantly increased by 59 percent from 32 to $51 \mathrm{ft}^{3} / \mathrm{s}$ (table 15).

When the medians of all monthly streamflows, 1-day annual maximum streamflow, and 7-day annual minimum streamflow computed from the USACE computed unregulated streamflow data for the post-dam period (water years 1969-2008) were compared with corresponding medians based on the pre-dam period (water years 1936-1968) measured streamflow data, their differences were not significant (tables 13 and 14). Pre- and post-dam period monthly precipitation data at the Eugene airport also were not significantly different (table 11). This would indicate that climate is less of a factor than the dams in explaining the significant difference between the pre- and post-dam period medians of measured streamflow data.

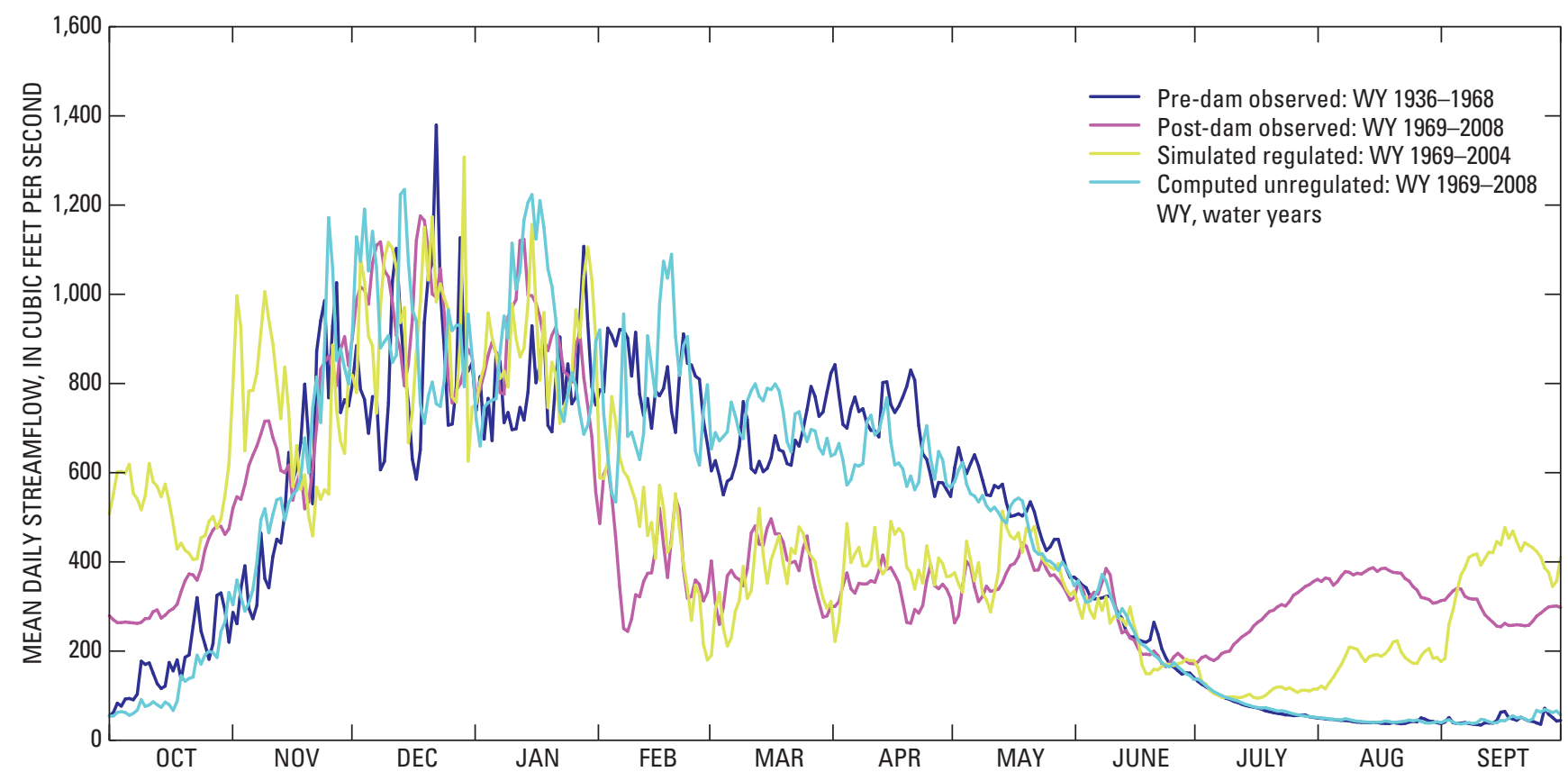

Figure 12. Mean daily streamflow in Reach 5 below Blue River Dam at Blue River, near Blue River, Oregon (14162000 and 14162200). 


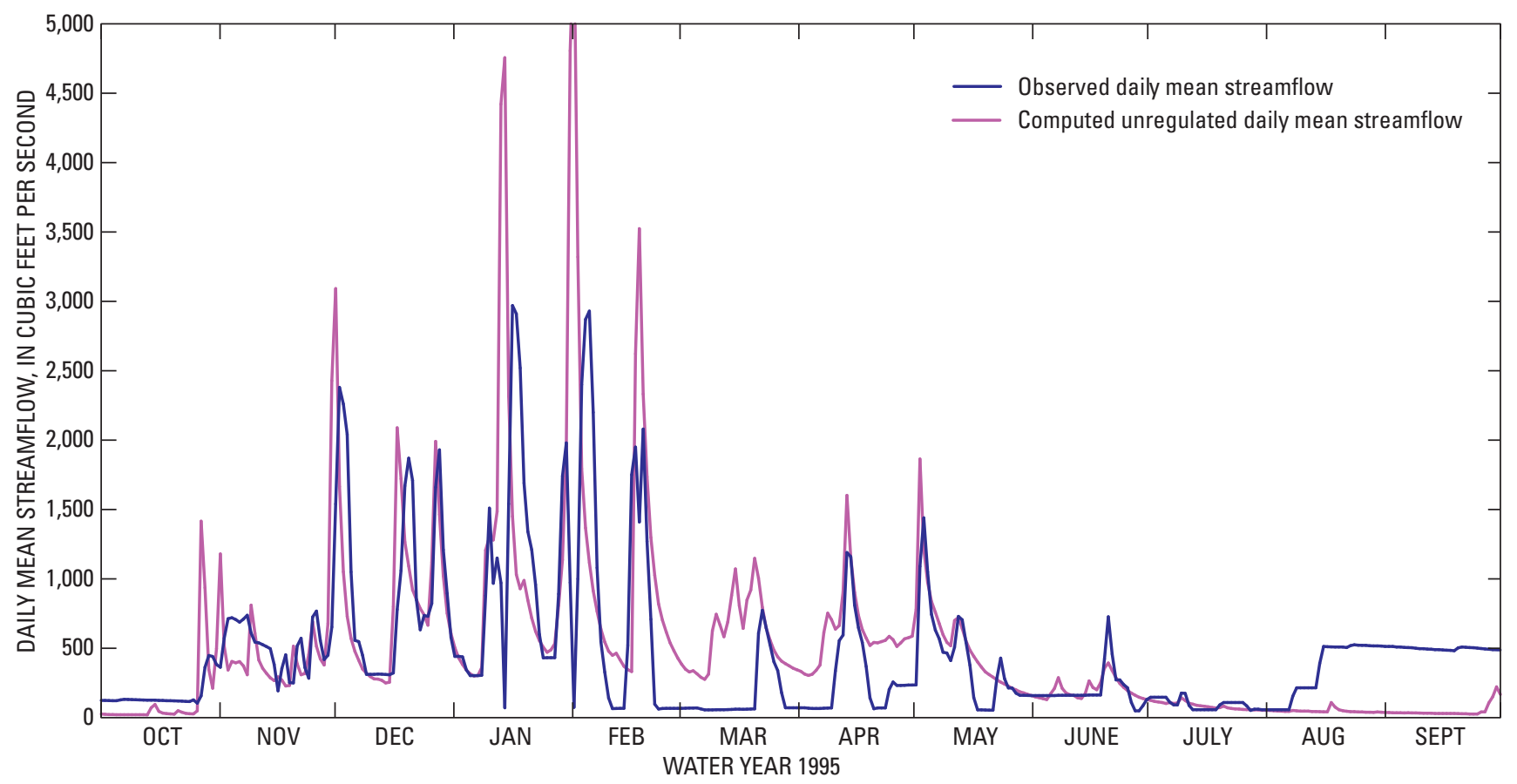

Figure 13. Daily mean streamflow in Reach 5 below Blue River Dam at Blue River, near Blue River, Oregon (14162200), water year 1995. 


\section{McKenzie River near Vida—Reach 7}

Changes in the annual distribution of daily streamflow for the Vida streamflow record are similar to but less pronounced than those for the South Fork McKenzie River below Cougar Dam and Blue River mean daily streamflow hydrographs (fig. 14). Streamflows decreased in the spring and increased during the summer and fall. The water year 1995 daily mean streamflow hydrograph shows a major reduction in peak flows (fig. 15); however, the effects of regulation are dampened in Reach 7 in the water year 1995 non-flood period compared to similar periods of the water year 1995 South Fork McKenzie River and Blue River hydrographs (figs. 11 and 13).

The 100-year flood magnitude for the pre-dam period (water years 1925-1962) was 69,970 $\mathrm{ft}^{3} / \mathrm{s}$ at the Vida streamflow-gaging station. The 100-year flood magnitude for the post-dam period (water years 1963-2008) decreased by 41 percent to $41,390 \mathrm{ft}^{3} / \mathrm{s}$ (table 12). The median of the annual 1-day maximum daily streamflows significantly decreased from 23,800 to $14,000 \mathrm{ft}^{3} / \mathrm{s}$ (table 13). The frequency of small and large floods (based daily mean streamflow data) during the two periods decreased by 95 and 72 percent, respectively (table 15).
Although the dams decreased flooding, the median of the annual 7-day minimum daily streamflows significantly increased from 1,553 to 1,951 $\mathrm{ft}^{3} / \mathrm{s}$ (table 13). Low flows (90th percentile streamflow exceedance) increased by 35 percent, from 1,600 to 2,167 ft $3 / \mathrm{s}$; however, the median date of the annual minimum streamflow remained almost unchanged (table 15). The standard deviation of the daily streamflows decreased by 19 percent, indicating that streamflows were slightly less variable during the post-dam period (table 13). Median monthly streamflow changes in Reach 7 were similar to changes in Reaches 3 and 5, as there was a near significant decrease and significant increase in streamflows from March to May and July to November, respectively (table 14).

Similar to Reaches 3 and 5, the medians of all almost the monthly streamflows, 1-day annual maximum streamflow, and 7-day annual minimum streamflow computed from the USACE computed unregulated streamflow data for the post-dam period (water years 1963-2004) for Reach 7 were not significantly different from the pre-dam period (water years 1925-1962) streamflow medians (tables 13 and 14). This would indicate that climate is less of a factor than the dams in explaining the significant difference between the pre- and post-dam period streamflow medians.

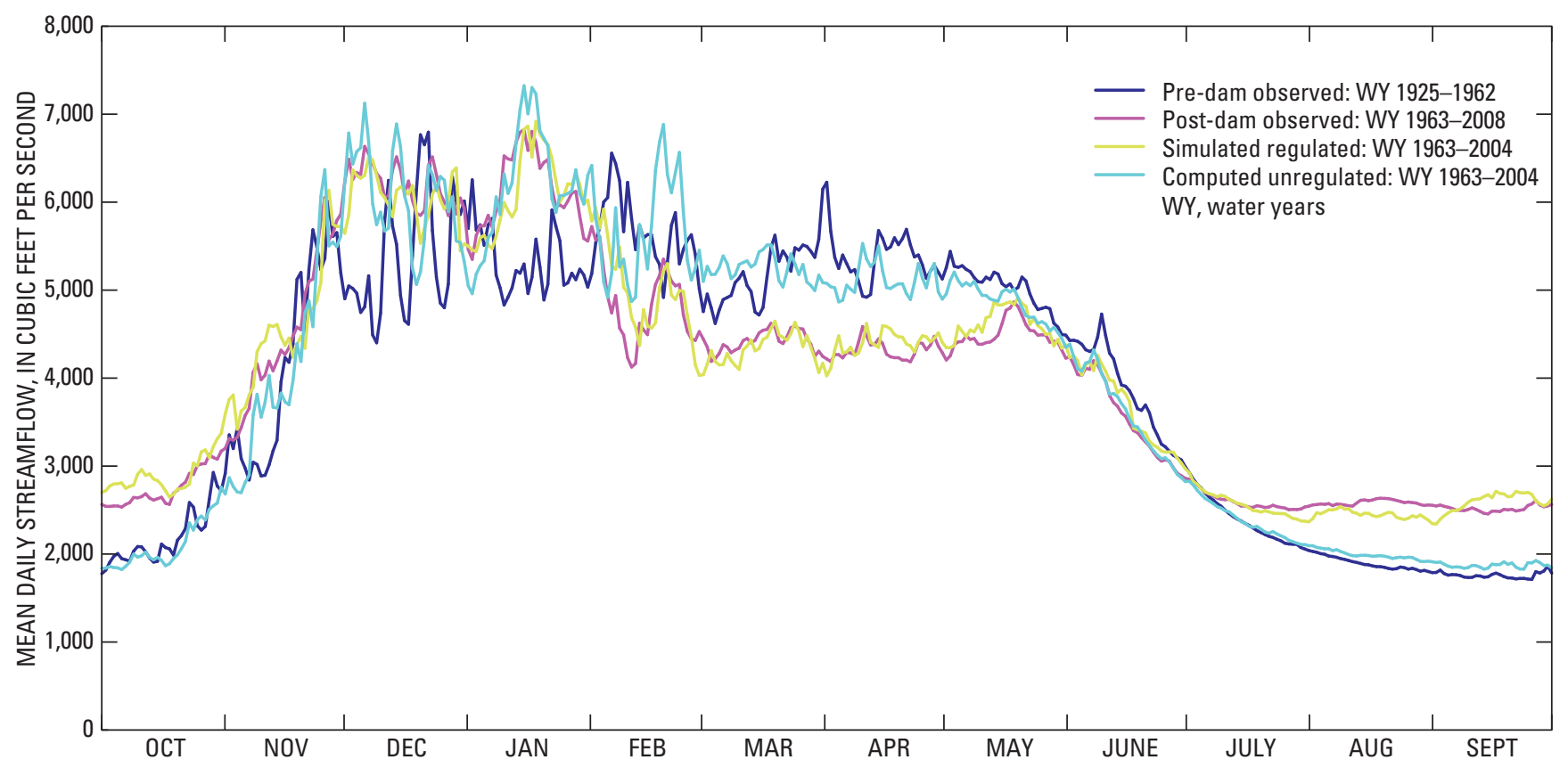

Figure 14. Mean daily streamflow in Reach 7 at McKenzie River near Vida, Oregon (14162500). 


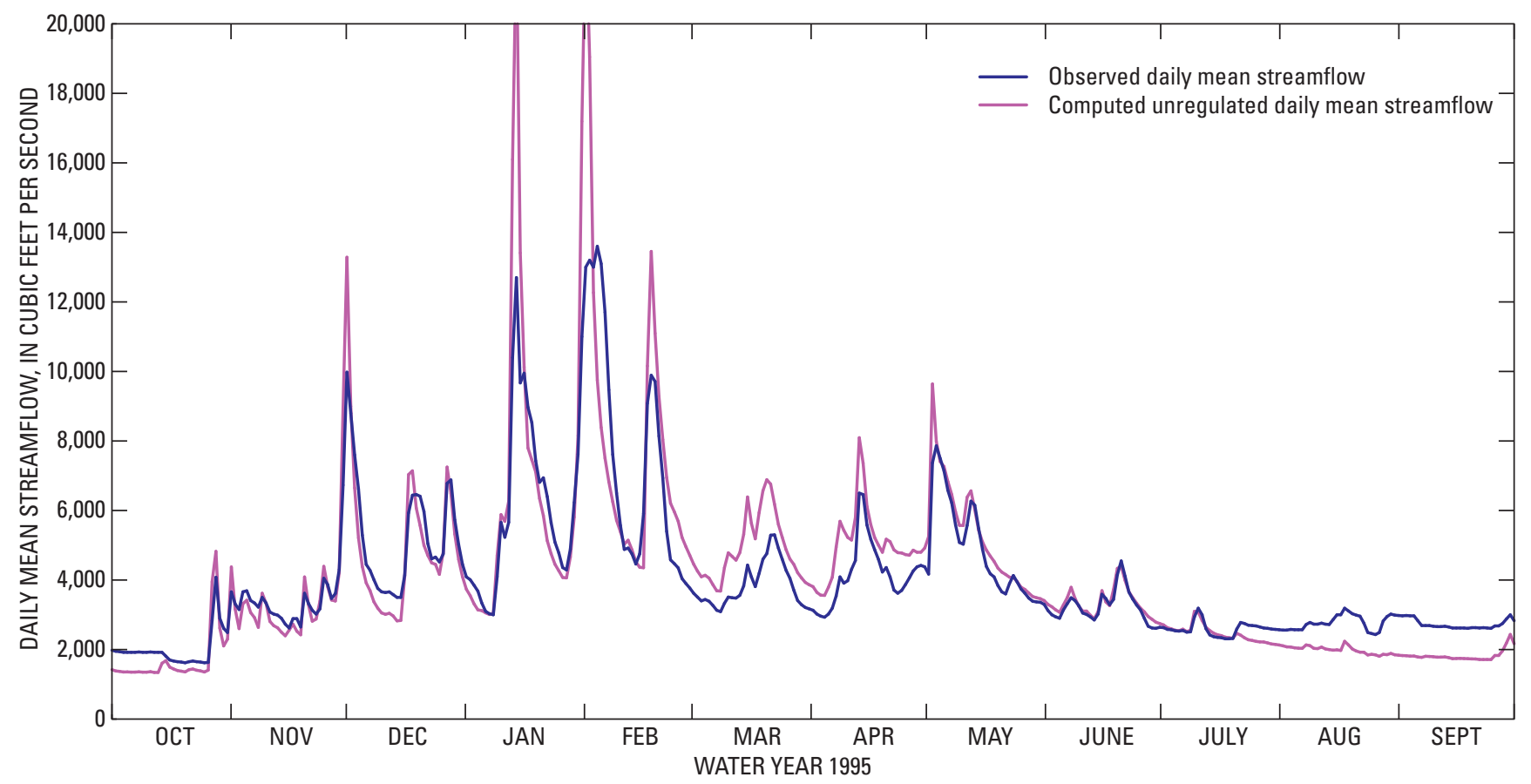

Figure 15. Daily mean streamflow in Reach 7 at McKenzie River near Vida, Oregon (14162500), water year 1995. 


\section{Leaburg and Walterville Canals-Reaches 8 and 10}

Reaches 8 and 10 extend the length of the Leaburg and Walterville canals, respectively. The canals have reduced streamflows in Reaches 8 and 10 throughout the year by 1,000 to $2,000 \mathrm{ft}^{3} / \mathrm{s}$ (iggs. 16 and $\underline{17}$ ). If both canals did not exist with the current operation of the upper basin dams (Carmen-SmithTrail Bridge, Cougar, and Blue River), minimum streamflows from July to October in Reaches 8 and 10 would be between 2,500 and 3,000 $\mathrm{ft}^{3} / \mathrm{s}$. Winter and spring streamflows would be higher if both canals and the upper basin dams did not exist. Flood events would be more frequent and have greater magnitudes. Minimum summer streamflow would be approximately 2,000 ft³/s (igs. 16 and 17).
Computing pre-dam and post-dam period streamflow metrics for Reaches 8 and 10 was not possible because of limited daily streamflow data. The USGS streamflow-gaging stations below Leaburg Dam, near Leaburg (14163150) and near Walterville (14163900) measures streamflow only in the river channel (canal bypass). Both gaging stations have been in operation only during the post-dam period since water year 1990. Although EWEB has measured streamflow on the Leaburg and Walterville canals since 1998, and the USGS measured streamflow data in the Waterville canal during 1927-33, simultaneous streamflow records of the canal and the canal bypass during the pre-dam period prior to 1963 do not exist for either reach.

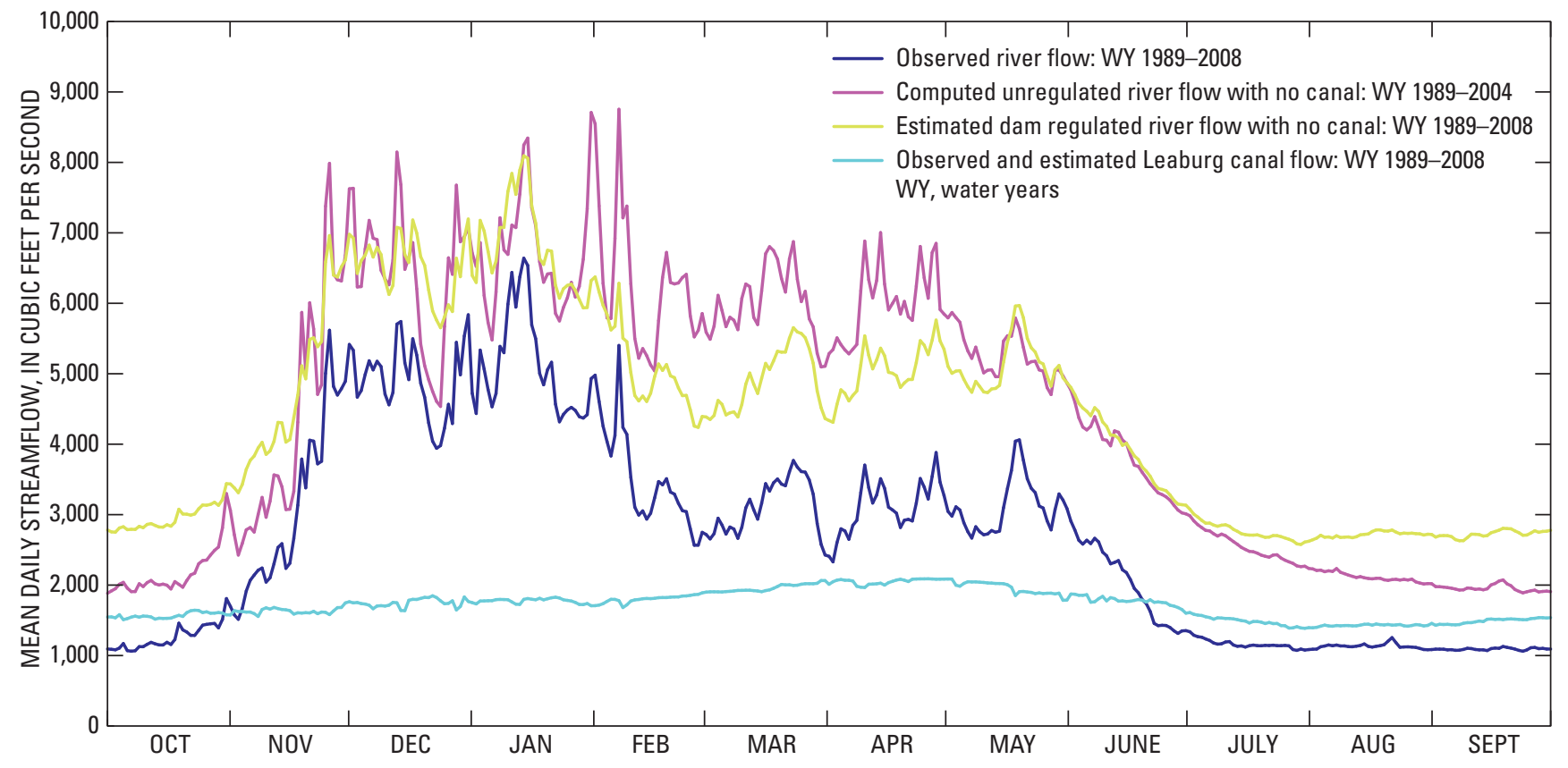

Figure 16. Mean daily streamflow in Reach 8 at McKenzie River below Leaburg Dam, near Leaburg, Oregon (14163150) and Leaburg Canal. 


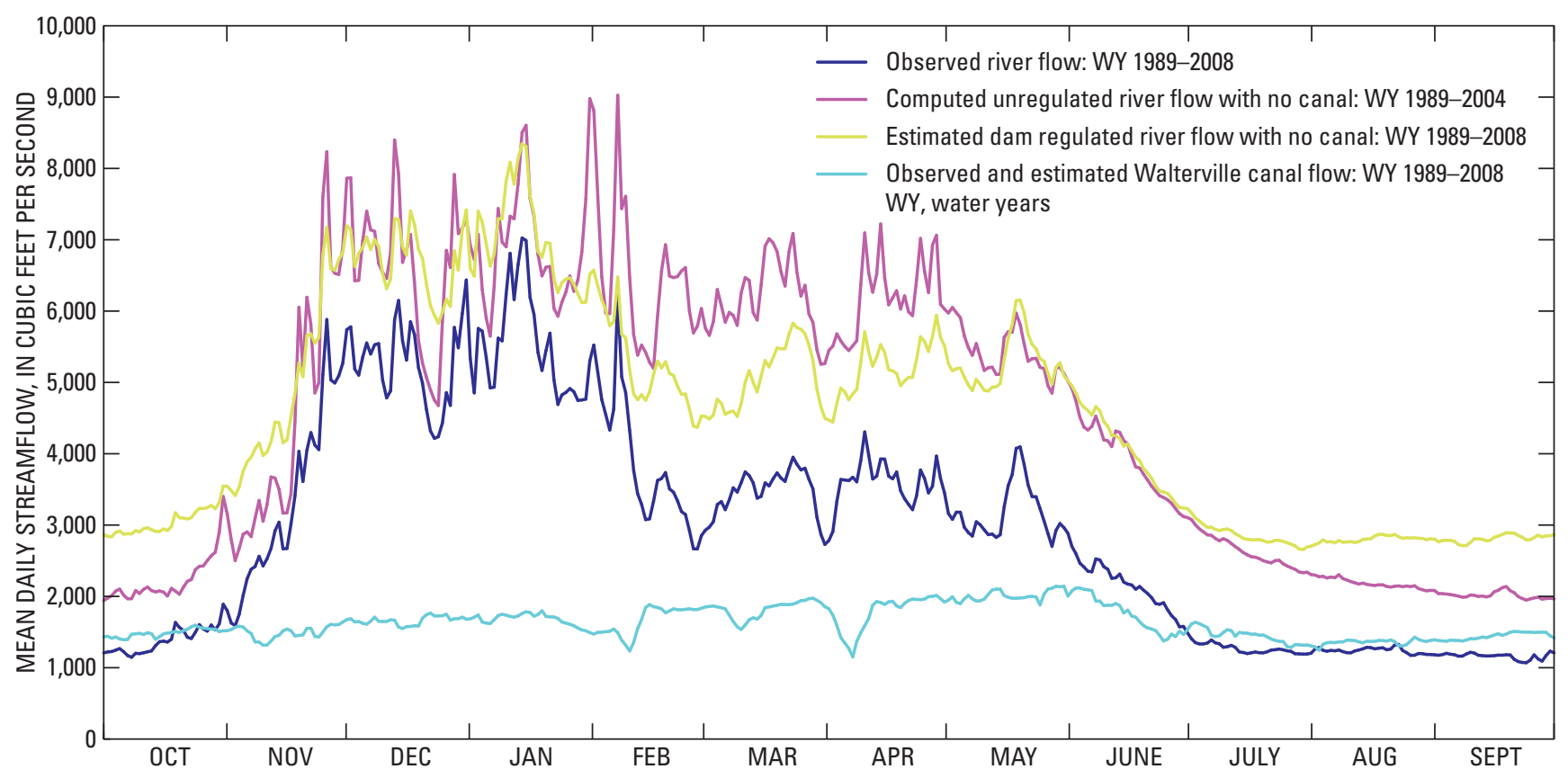

Figure 17. Mean daily streamflow in Reach 10 at McKenzie River near Walterville, Oregon (14163900) and Walterville Canal. 


\section{McKenzie River-Reach 12}

The cumulative effect of the upper basin dams and canals on McKenzie River streamflow is evident in Reach 12 near the Willamette River confluence (ig. 18). Spring streamflows from February to May are lower and summer streamflows from July to September are higher in the post-dam period than in the pre-dam period. The magnitudes of high flow events also are lower in the post-dam period than in the pre-dam period (fig. 19).

The median 7-day minimum annual streamflow significantly increased in the post-dam period from 1,744 to $2,131 \mathrm{ft}^{3} / \mathrm{s}$ (table 13). Another low-flow metric (90th percent streamflow exceedance) increased by 31 percent (table 15). However, the pre- and post-dam period medians of annual 1-day maximum streamflow significantly decreased, from 34,700 to $22,200 \mathrm{ft}^{3} / \mathrm{s}$ (table 13). The frequency of small (2-year to less than 10-year) floods (based on daily mean streamflow data) during the two periods decreased by 76 percent. However, the median date of the annual minimum streamflow remained relatively unchanged (table 15). Median monthly streamflows from March through May significantly decreased as a consequence of streamflow regulation during the post-dam period. Median monthly streamflows from July through November significantly increased (table 14).

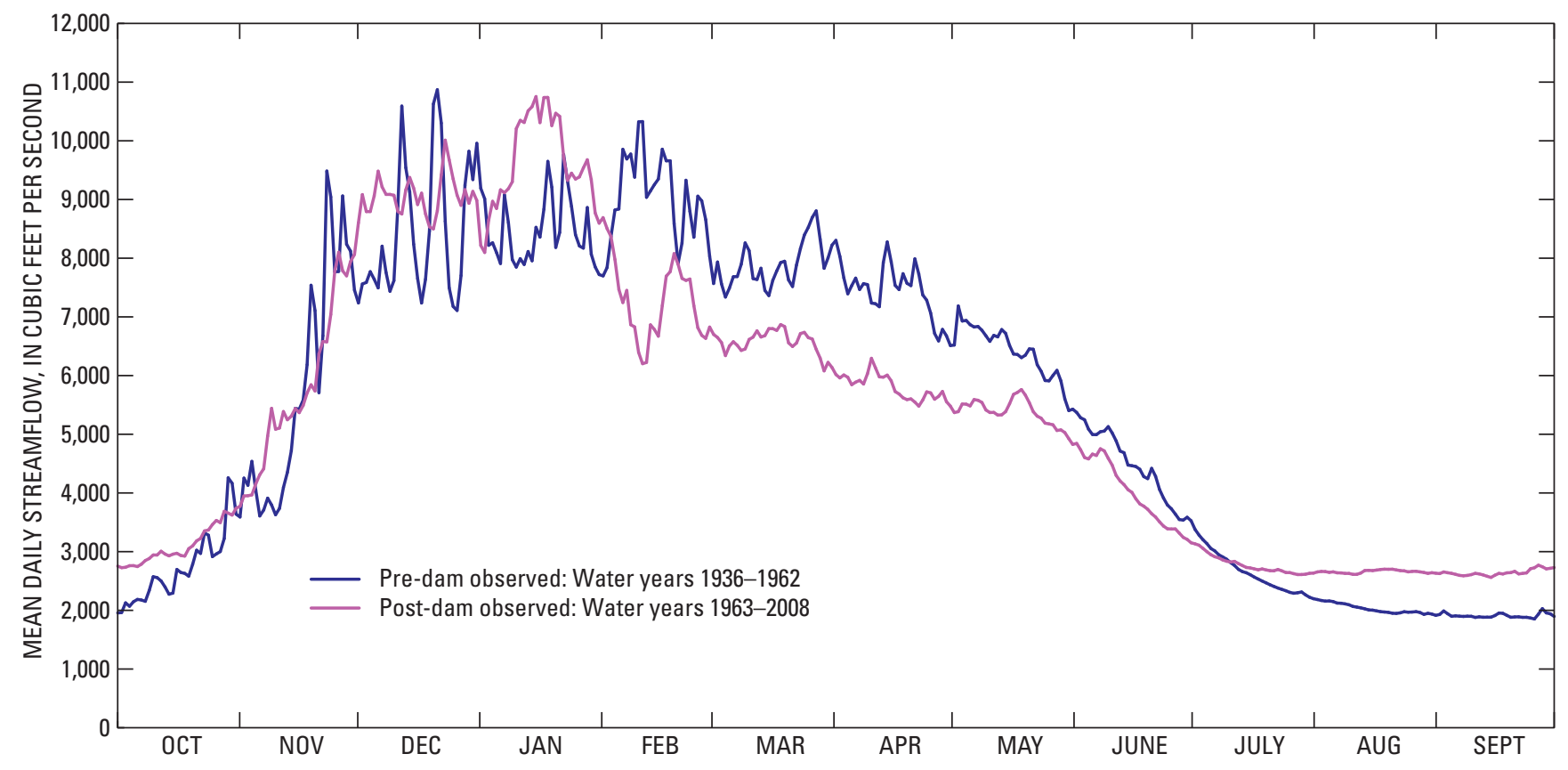

Figure 18. Mean daily streamflow in Reach 12 at McKenzie River near Coburg, Oregon (14165500). 


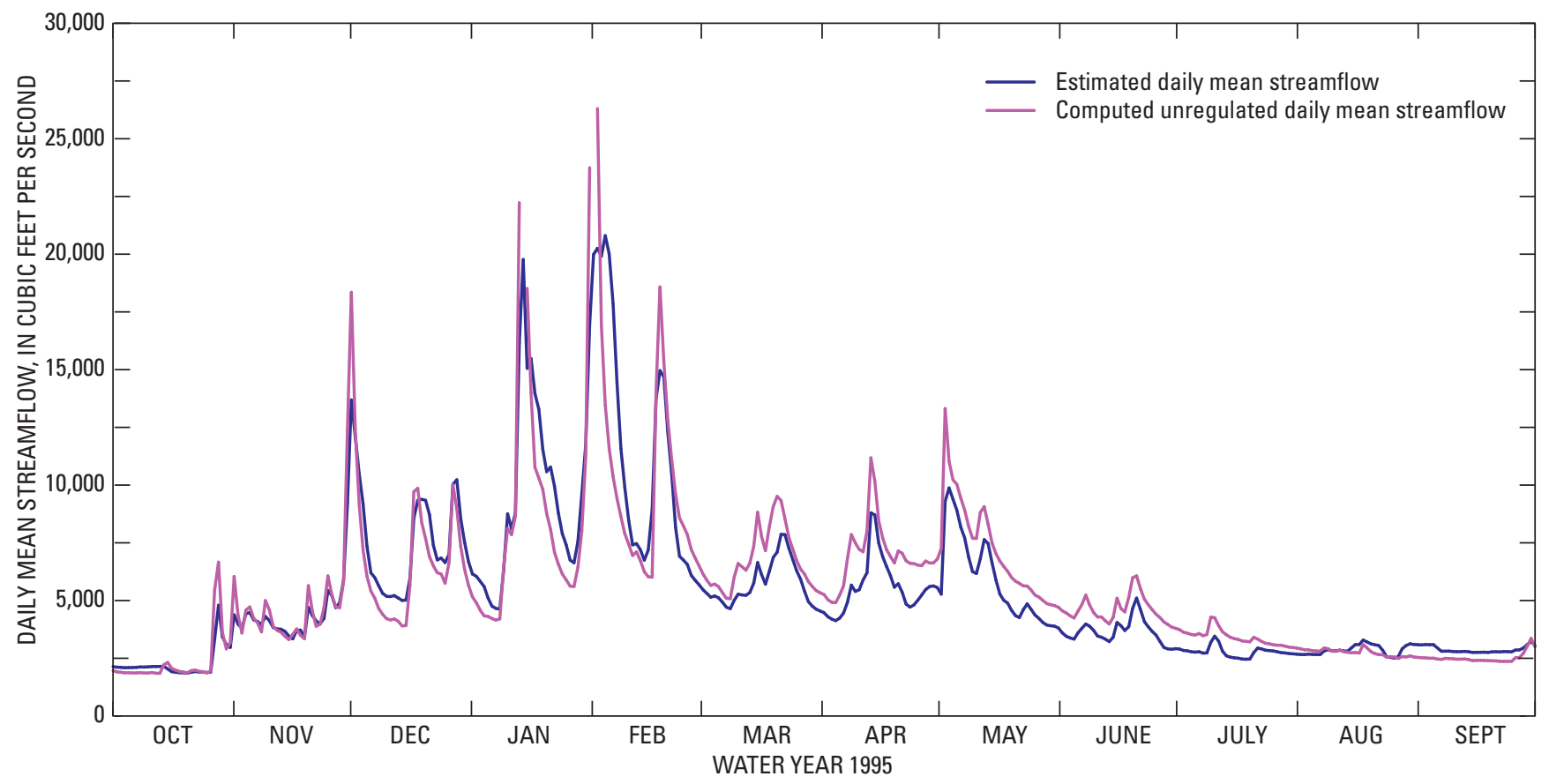

Figure 19. Daily mean streamflow in Reach 12 at McKenzie River near Coburg, Oregon (14165500), water year 1995. 


\section{Stream-Temperature Assessment}

\section{Key Elements}

- A total of 112.4, 6.3, and 55.7 mi of McKenzie River basin mainstem and tributary stream reaches are listed as thermally impaired for salmonid and bull trout spawning and rearing.

- Streamflow below Cougar and Blue River Dams has been or currently is cooler in the summer and warmer in the fall since regulation.

- USGS stream-temperature data has been collected at 14 active and now inactive USGS streamflow-gaging stations since as early as 1951 in the McKenzie River basin.

- Blue River and South Fork McKenzie River stream temperatures have a slight effect on stream temperatures at McKenzie River near Vida during September and October.

Stream temperature in the McKenzie River basin is major concern with regard to the habitat of fish and other aquatic species. For many aquatic plants and animals, optimal temperatures are critical for different phases of their life cycle. Temperature also has a direct relation to water-quality parameters, such as dissolved oxygen concentrations, biochemical oxygen demand rates, algae production, and contaminant toxicity.

\section{Stream-Temperature Criteria}

In the McKenzie River basin, anthropogenic factors that affect stream temperatures include the removal of riparian shade buffers, channel geomorphology alterations, canal streamflow diversions, and reservoir streamflow releases (Oregon Department of Environmental Quality, 2006). The ODEQ surveyed streams and rivers using Federal Clean Water Act standards to determine which reaches were thermally impaired and did not meet State temperature standards for salmonid rearing, spawning, and cold water refuges. Stream reaches in violation of the standards were placed on the Federal Clean Water Act section 303(d) list (Oregon Department of Environmental Quality, 2009), and a Total Maximum Daily Load (TMDL) plan must be developed. McKenzie River basin stream reaches listed by the ODEQ and the temperature criteria they exceeded are shown in table 16. In total there were $112.4,6.3$, and $55.7 \mathrm{mi}$ of stream reaches listed as thermally impaired for salmonid and bull trout spawning and rearing. As part of the McKenzie River TMDL plan, monthly target streamflow release temperatures were developed for the Cougar and Blue River dams (table 17). Summer release targets are in the optimum/preferred range for all life stages of the Chinook salmon. Spring and fall targets are in the optimum/preferred range for Chinook incubation and juvenile rearing (Gregory and others, 2007a) (table 18).

Table 16. Temperature criteria for Federal Clean Water Act section 303(d) listed segments in the McKenzie River basin, Oregon.

[Data from Oregon Department of Environmental Quality (2006). Abbreviation: ${ }^{\circ} \mathrm{C}$, degrees Celsius]

\begin{tabular}{|c|c|c|c|}
\hline River & River mile & Season & $\begin{array}{c}\text { Exceedance } \\
\text { criteria }\end{array}$ \\
\hline McKenzie River & 0 to 34.1 & Summer & Rearing: $17.8^{\circ} \mathrm{C}$ \\
\hline McKenzie River & 34.1 to 54.4 & Spring/Summer/Fall & Rearing: $17.8^{\circ} \mathrm{C}$ \\
\hline McKenzie River & 54.4 to 83 & Summer & Bull Trout: $10.0^{\circ} \mathrm{C}$ \\
\hline South Fork McKenzie River & 0 to 4.5 & Spring/Summer/Fall & Spawning: $12.8^{\circ} \mathrm{C}$ \\
\hline Blue River & 0 to 1.8 & Spring/Summer/Fall & Spawning: $12.8^{\circ} \mathrm{C}$ \\
\hline Blue River & 1.8 to 15.5 & Summer & Rearing: $17.8^{\circ} \mathrm{C}$ \\
\hline Deer Creek & 0 to 8.3 & Summer & Rearing: $17.8^{\circ} \mathrm{C}$ \\
\hline French Pete Creek & 0 to 12.9 & Summer & Bull Trout: $10.0^{\circ} \mathrm{C}$ \\
\hline Horse Creek & 0 to 14.2 & Summer & Bull Trout: $10.0^{\circ} \mathrm{C}$ \\
\hline Mill Creek & 0 to 2.7 & Summer & Rearing: $17.8{ }^{\circ} \mathrm{C}$ \\
\hline Mohawk River & 0 to 25.4 & Summer & Rearing: $17.8^{\circ} \mathrm{C}$ \\
\hline Shotgun Creek & 0 to 6.6 & Summer & Rearing: $17.8^{\circ} \mathrm{C}$ \\
\hline Unnamed trib. of Rebel Creek & 0 to 1.2 & Summer & Rearing: $17.8^{\circ} \mathrm{C}$ \\
\hline
\end{tabular}


Table 17. Monthly streamflow-release target temperatures for Cougar and Blue River Dams, McKenzie River basin, Oregon.

[Temperatures in degrees Celsius. Reference: Oregon Department of Environmental Quality (2006)]

\begin{tabular}{lccccccc}
\hline \multirow{2}{*}{ Dam name } & \multicolumn{7}{c}{ Temperature (degrees Celsius) } \\
\cline { 2 - 8 } & Apr. & May & June & July & Aug. & Sept. & Oct. \\
\hline Cougar River & 5.5 & 7.7 & 10.0 & 11.7 & 10.9 & 9.5 & 7.2 \\
Blue River & 5.5 & 7.6 & 9.9 & 11.2 & 10.6 & 9.5 & 7.2 \\
\hline
\end{tabular}

Table 18. Water temperature criteria for listed and sensitive fish species in the McKenzie River basin, Oregon. [Data from Gregory and others (2007a)]

\begin{tabular}{|c|c|c|c|c|c|}
\hline \multirow[b]{2}{*}{ Species } & \multirow[b]{2}{*}{ Lifestage } & \multicolumn{4}{|c|}{ Temperature criteria (degrees Celsius) } \\
\hline & & $\begin{array}{l}\text { Optimum/ } \\
\text { preferred }\end{array}$ & $\begin{array}{l}\text { Avoidance/ } \\
\text { tolerance }\end{array}$ & $\begin{array}{c}\text { Stress/ } \\
\text { delay }\end{array}$ & $\begin{array}{c}\text { Upper } \\
\text { lethal } \\
\text { limit }\end{array}$ \\
\hline \multirow[t]{8}{*}{ Chinook salmon } & Adult & Holding: $8.0-12.5$ & All: 9.4, 14.1 & Migration: 21.0 & 25.0 \\
\hline & & & Fall: $10.6,19.4$ & Disease: 15.5 & \\
\hline & & & Spring: $3.3,13.3$ & & \\
\hline & & & Summer: $13.9,20.0$ & & \\
\hline & Spawning & & $5.6,12.8$ & 16.0 & \\
\hline & Incubation & $4.5-12.8$ & $1.7,14.4$ & & \\
\hline & Juvenile & Rearing: 7.2-15.6 & & Rearing: 19.1 & Rearing: 22.2 \\
\hline & & & & Migration: 18.3 & Migration: 18.3 \\
\hline \multirow[t]{4}{*}{ Steelhead } & Adult & $10.0-12.8$ & $7.2,14.4$ & & 23.9 \\
\hline & Spawning & & $3.9,9.4$ & & \\
\hline & Incubation & 10.0 & & & \\
\hline & Juvenile & & & & \\
\hline
\end{tabular}




\section{Effect of Reservoirs}

A flood control reservoir can significantly affect downstream water temperature. Similar to lakes and other natural water bodies, a thermocline typically will develop in a reservoir during the spring and summer as the upper layers are warmed by solar radiation. Water releases from the top of thermally stratified reservoirs will be warmer than reservoir inflows, whereas releases from the reservoir bottom will be colder. In autumn, when the upper layer temperatures have cooled, thermal stratification is eliminated as vertical mixing occurs. At this time, the reservoir typically is drawn down to increase the winter flood storage capacity, and the downstream water temperatures will reflect reservoir temperatures.

Streamflow releases from Cougar Dam, prior to the recent construction of the water temperature control (WTC) tower in 2006, and Blue River Dam came from a lower level of the reservoir pool. As a result, summer streamflows were unnaturally cooler and fall temperatures were unnaturally warmer.

Altered streamflows caused by reservoir regulation can affect the downstream temperature regime in other ways as well. When winter and spring flooding extremes are reduced and summer streamflows are increased, natural channel processes are affected. For example, Gregory and others (2007a) found in the Willamette River basin that alcoves on floodplains and gravel bars produce pockets of water cooler than that in the well-mixed portions of the stream. A decrease in these alcoves caused by streamflow regime alteration could potentially reduce the availability of "temperature refuges" that temperature-sensitive aquatic species utilize during periods of heat stress.

\section{Stream-Temperature Data}

The USGS has been collecting stream-temperature data in the McKenzie River basin since 1951 at 14 active and now inactive USGS streamflow-gaging stations on the mainstem and tributaries (table 19). Records for these sites include daily minimum, maximum, and mean stream temperatures. Although the records for some of these sites contain some data gaps, standard USGS data collection and publication protocols were always used. Stream temperatures in the channel cross sections were periodically checked and verified with the monitoring instrumentation (U.S. Geological Survey, 2009).

Table 19. U.S. Geological Survey stream-temperature monitoring sites in the McKenzie River basin, Oregon.

[Stream-temperature data collection is not continuous for many of these sites. The years shown in the period of record may have had partial or complete monitoring for the year]

\begin{tabular}{cll}
\hline $\begin{array}{c}\text { Station } \\
\text { No. }\end{array}$ & \multicolumn{1}{c}{ Streamflow-gaging and stream-temperature station name } & \multicolumn{1}{c}{ Period of record } \\
\hline 14158850 & McKenzie River below Trail Bridge Dam near Belknap Springs & $1976-85 ; 1992-94 ; 1996$ \\
14159000 & McKenzie River at McKenzie Bridge & $1976-85 ; 1992 ; 1993$ \\
14159100 & Horse Creek near McKenzie Bridge & $1963-69 ; 1983 ; 1984 ; 1992 ; 1993$ \\
14159110 & McKenzie River above South Fork, near Rainbow & $1982-2006$ \\
14159200 & South Fork McKenzie River above Cougar Lake, near Rainbow & $1957-87 ; 2000-08$ \\
14159500 & South Fork McKenzie River near Rainbow & $1955-2008$ \\
14161100 & Blue River below Tidbits Creek, near Blue River & $1963-87$ \\
14161500 & Lookout Creek near Blue River & $1951-55 ; 1963-81$ \\
14162000 & Blue River near Blue River & $1961-1964$ \\
14162200 & Blue River at Blue River & $1966-2008$ \\
14162500 & McKenzie River near Vida & $1961-85 ; 2000-08$ \\
14163900 & McKenzie River near Walterville & $1992-99 ; 2001-08$ \\
14165000 & Mohawk River near Springfield & $1963-69 ; 1983-84$ \\
14165500 & McKenzie River near Coburg & $1963-75 ; 1984$ \\
\hline
\end{tabular}




\section{Results and Discussion}

The Carmen-Smith-Trail Bridge Dam complex in Reach 1 has not affected the natural seasonal pattern of stream temperatures (Stillwater Sciences, 2006a). However, water temperatures in the upper basin stream reaches are listed as thermally impaired in violation of the bull trout $12^{\circ} \mathrm{C}$ temperature criterion (Oregon Department of Environmental Quality, 2006). Mean daily maximum stream temperatures for the McKenzie River below Trail Bridge Dam (14158850) and McKenzie River at McKenzie Bridge (14159000) stations (both located downstream of the Carmen-Smith-Trail Bridge Dam complex) have a stream temperature seasonal distribution similar to that at Horse Creek near McKenzie Bridge (14159100) (which is unaffected by the dam complex) (fig. 20). However, the annual maximum stream temperature for McKenzie River below Trail Bridge Dam (14158850) occurs slightly later in the summer than at the two other stations. (The graphs were created by computing the mean of all daily maximum temperatures for each calendar day from a record of a site.)

On the South Fork McKenzie River (Reach 3) natural temperature patterns (warm summer and cool winter) are apparent in data collected at the streamflow-gaging station upstream of the Cougar Reservoir (14159200) and pre-dam period data collected at the streamflow-gaging station downstream of the reservoir (14159500) (fig. 21). However, the post-dam period (1961-2001) had unnaturally cool temperatures for most of the summer and unnaturally warm temperatures in the fall. Since construction of the WTC tower in 2006, the seasonal distribution of temperatures has returned to a more natural pattern.

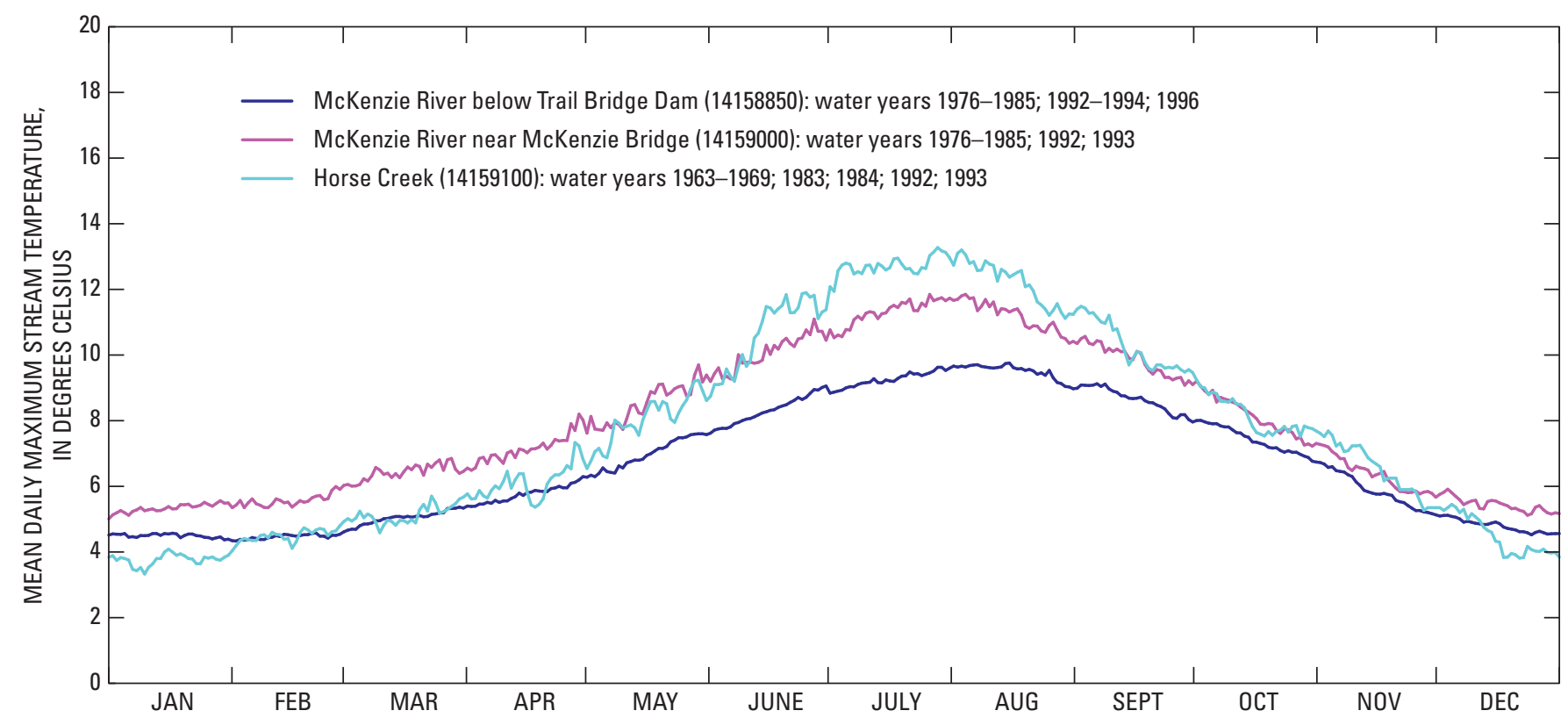

Figure 20. Mean daily maximum stream temperatures in the upper McKenzie River basin (Reach 1), Oregon. 


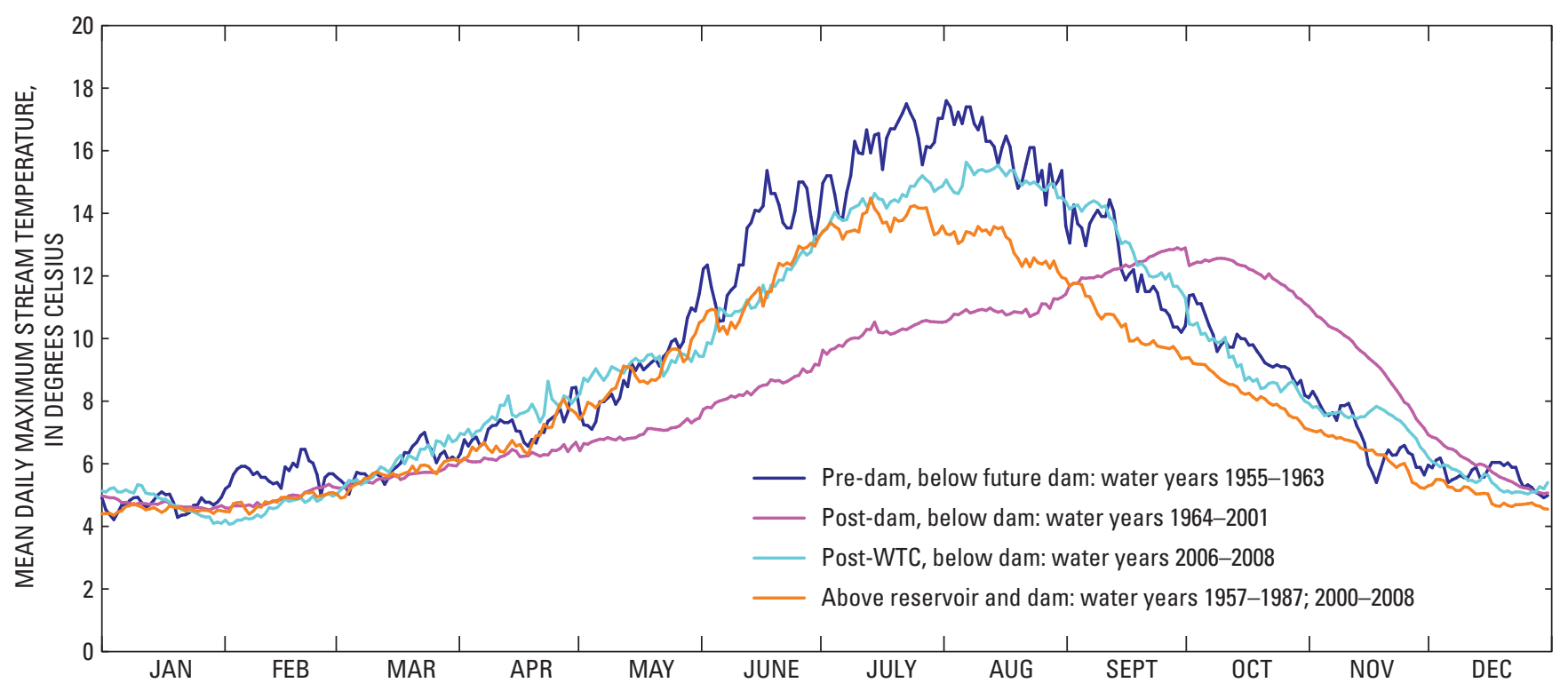

Figure 21. Mean daily maximum stream temperatures in the South Fork McKenzie River (Reach 3), Oregon.

For the Blue River (Reach 5), the effect of the dam on stream temperatures is readily apparent when compared to the natural conditions of the pre-dam period (fig. 22). In mid-July stream temperatures during the post-dam period are almost $10^{\circ} \mathrm{C}$ cooler than the pre-dam stream temperatures. In early October, the temperatures during the post-dam period are more than $4^{\circ} \mathrm{C}$ warmer than pre-dam temperatures. At the time this report was written there were no plans to construct a WTC tower for the Blue River Dam. However, the downstream thermal effect of Blue River is limited because the mean annual streamflow of Blue River (14162200) is only approximately 10 percent of the mean annual streamflow at the McKenzie River near Vida (14162500) streamflow-gaging station.
Overall, stream temperatures increase from upstream to downstream throughout the length of the McKenzie River (fig. 23). With the exception of Blue River, all the locations have their maximum temperatures in July or early August. Blue River and South Fork McKenzie River stream temperatures appear to have a slight effect at the McKenzie River near Vida (14162500) during September and October. Although the Coburg monitoring station (Reach 12) is downstream of the Walterville station (Reach 10), the Walterville stream temperatures are higher than the Coburg stream temperatures. Because the Walterville site is located on a reach of the river below which streamflow is diverted by the Walterville canal, the higher stream temperatures could be a result of year-round streamflows that are 1,000 to $2,000 \mathrm{ft}^{3} / \mathrm{s}$ less than reaches not affected by canal diversions in the lower McKenzie River basin. 


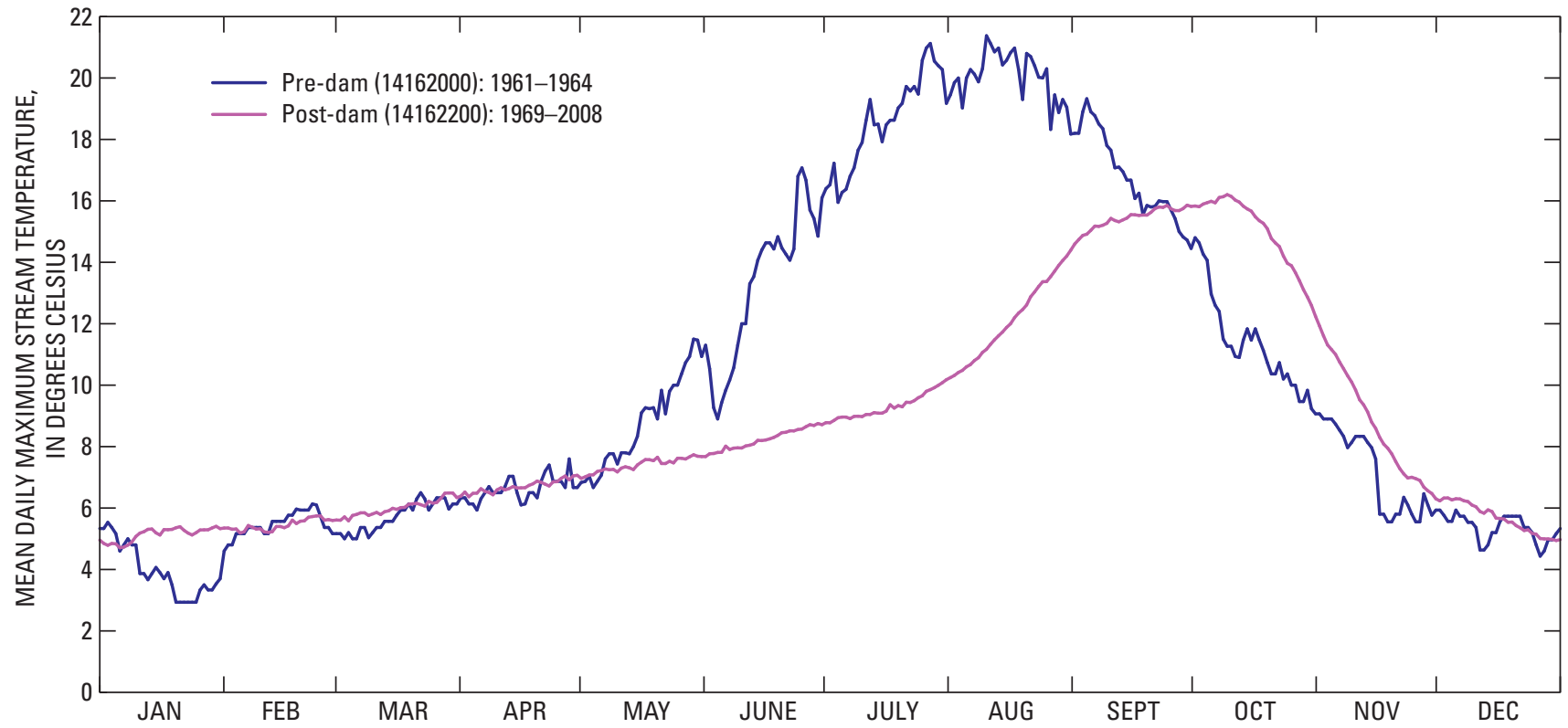

Figure 22. Mean daily maximum stream temperatures in Blue River (Reach 5), Oregon.

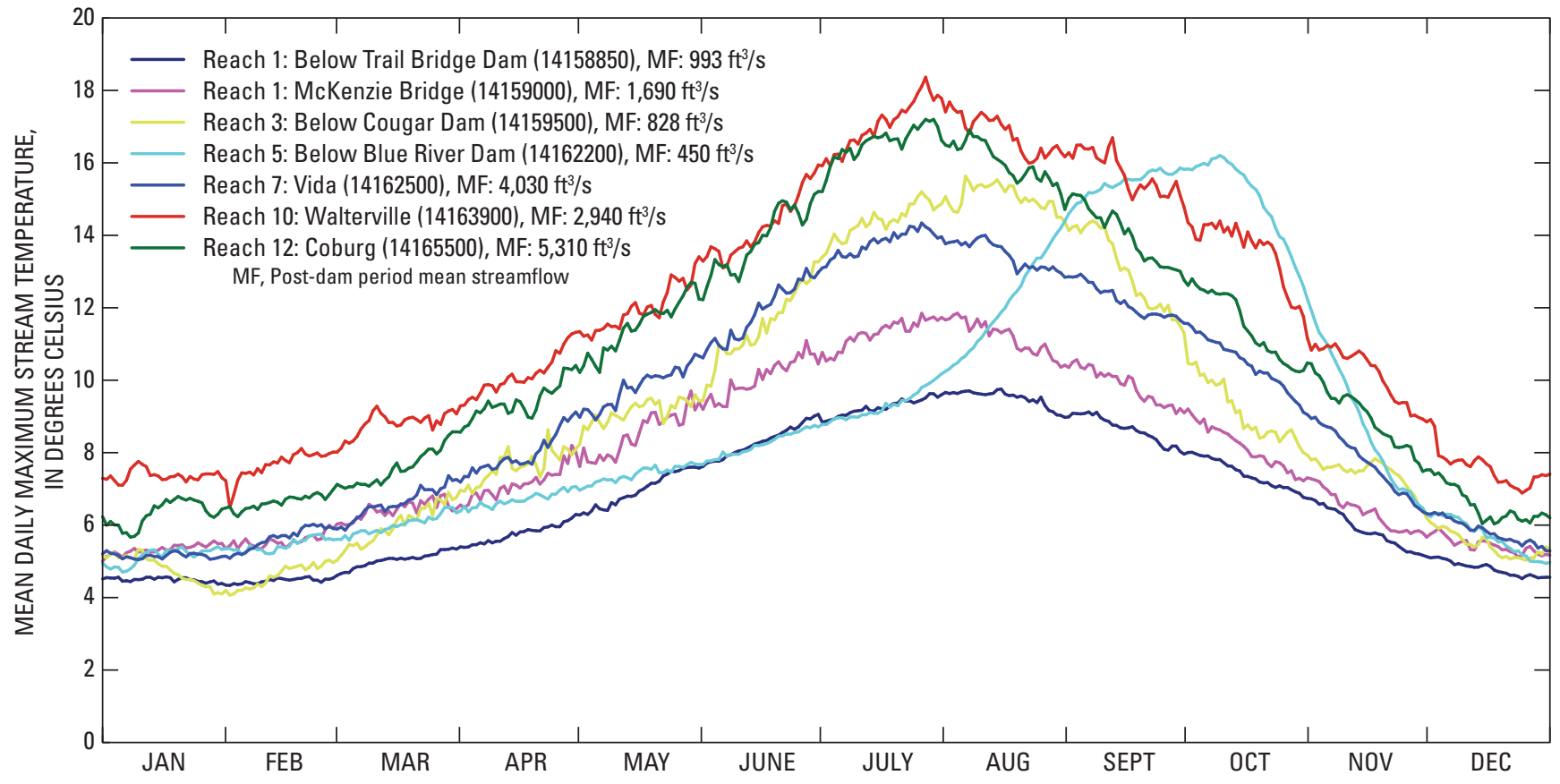

Figure 23. Post-dam period mean daily maximum stream temperatures at monitoring stations on the McKenzie, South Fork McKenzie, and Blue Rivers, Oregon. 


\section{Geomorphology and Ecology}

\section{Key Elements}

- McKenzie River channel morphology was evaluated using reach characterization, historical channel mapping, and specific gage analysis methods.

- The upper McKenzie River basin along Reach 1 is narrow, steep, and confined within a relatively narrow floodplain. The channel and floodplain width increase substantially along Reach 2. Exemplar species include spring Chinook salmon and bull trout.

- The middle McKenzie River basin (Reaches 3-8) is moderately steep and has a sometimes confined valley floor with narrow floodplains. Exemplar aquatic and terrestrial species include spring Chinook salmon, bull trout, Oregon chub, Pacific and western brook lamprey, western pond turtle, red-legged frog, cottonwood, and alder.

- The lower McKenzie River basin (Reaches 9-12) occupies a wide alluvial corridor that increases in width as it approaches the Willamette River confluence. Exemplar species includes those listed above.

- Bed-material transport has presumably decreased appreciably since the construction of Cougar and Blue River Dams, which are located on historically sedimentrich tributaries. Decreased sediment supply resulting from the dams likely contributed to a decrease in gravel bars between 1939 and 2005 in downstream reaches, particularly along the lower McKenzie River basin (Reaches 9-12). Previous studies have shown that the upper McKenzie River basin has very low sediment yield rates; therefore, Trail Bridge Reservoir probably has less of an effect on sediment transport than the Cougar and Blue River Reservoirs.

- Between 1939 and 2005, secondary channel features and sinuosity also decreased, particularly along the lower reaches.

- The historical channel changes observed for 1939-2005 are likely a function of streamflow reduction and bed-material trapping by the dams, but other influences, including bank stabilization, land use, channel clearing, and natural variability in streamflow regime also are important factors.

This section provides a background assessment of geomorphic, ecological, and biological characteristics within the McKenzie River basin and also discusses the effect of dams, bank hardening, and land-use changes. Instream physical habitat and riparian ecosystems are linked through a series of complex interactions. Within the McKenzie River riparian corridor, key areas of interest include pools, offchannel aquatic habitat, depositional bed features, and floodplains. The biological assessment draws primarily from Gregory and others (2007a), who identified key species and ecological processes in the Coast and Middle Fork Willamette basins that are applicable to the McKenzie River basin. For this study, nine exemplar aquatic and terrestrial species selected for the McKenzie River basin, including five native fish species (spring Chinook salmon, bull trout, Pacific and western brook lamprey, Oregon chub), red-legged frog, western pond turtle, black cottonwood, and white alder. These nine species were selected based on information in the literature and discussions with regional and local biologists.

\section{Endangered Species Act Background}

The Willamette Project Biological Opinion (National Marine Fisheries Service, 2008b) identified key threats and limiting factors in the McKenzie River basin to fish survival. These included (1) the effects of reduced peak streamflows on channel complexity, gravel and large wood recruitment, maintenance of riparian vegetation, and formation of pools, (2) the lack of gravel recruitment because of capture by upstream reservoirs, and (3) elevated water temperatures downstream of dams, resulting in premature hatching and emergence of salmonid fry.

The USACE Supplemental Biological Assessment report (U.S. Army Corps of Engineers, 2007) summarizes major issues regarding critical habitat for endangered species, particularly spring Chinook salmon. They highlight many of the same issues described above, including water temperatures downstream of the dams, lack of spawning gravel and coarsening of substrate downstream of dams, low recruitment of large wood, and the loss of side channels, islands, and habitat channel complexity. They also discussed other concerns, including (1) the loss of natural floodplain function (which has been most prominent along the lower parts of the mainstem McKenzie River and South Fork McKenzie River), (2) alteration of important seasonal streamflow events, (including flows during the fall spawning period, winter and spring floods, and flushing streamflows), and (3) the occurrence of unnatural streamflow fluctuations (caused by the high ramping rates of dam streamflow releases). Alteration of discharge and temperature, which are major cues for salmonids during different life stages, can affect the timing, growth, and survival of riverine salmonid life stages. An earlier USACE report (U.S. Army Corps of Engineers, 2000) also recommended that habitat improvement projects, streamflow targets, and ramping rates be established, researched, and monitored for spring Chinook salmon. 


\section{Methods}

To better understand habitat requirements and ecological processes in the McKenzie River basin, the analysis draws largely on the Coast and Middle Fork Sustainable Rivers Project recommendations (Gregory and others, 2007b), the USACE Willamette Supplemental Biological Assessment (U.S. Army Corps of Engineers, 2007), and the Willamette Project Biological Opinion (National Marine Fisheries Service, 2008b). Together, these reports provide a historical summary and environmental baseline of the Willamette River basin as well as the current status of salmonid stocks and factors limiting their survival/recovery. Gregory and others (2007a) provide an overview of streamflow needs for riparian and floodplain vegetation, birds and mammals, aquatic invertebrates, amphibians, reptiles, and eight exemplar species of fish in the Willamette River basin. Discussions on critical issues and important species related to environmental flows from agency and university biologists who work within the McKenzie River basin also were incorporated.

A series of reconnaissance level geomorphic analyses were conducted to evaluate the role of intrinsic controls (those imposed by geology and physiography) versus external factors (including discharge, sediment supply, and large wood) on channel morphology. The geomorphology-related activities used in this study included reach characterization, historical channel mapping, and specific gage analysis.

\section{Reach Characterization}

Channel morphology along each of the 12 reaches was characterized by mapping the active channel from aerial photographs taken in 2005, where the active channel was considered the area inundated during annual high water and included the primary (wetted) channel as well as sparsely vegetated gravel bars and secondary channel features (side channels, alcoves). Mapping of the active channel was performed at a scale of 1:5,000 using publicly available digital orthophotographs taken in 2005 and produced by the U.S. Department of Agriculture National Agriculture Imagery Program (Oregon State University, 2009). The geologic floodplain, representing areas that were the floodplain during the Holocene, was digitized at a scale of 1:10,000. The geologic floodplain was compiled from previous mapping (O’Connor and others, 2001), from areas corresponding with the 100- and 500-year flood inundation zone (University of Oregon, 2009), and from the 10-m Digital Elevation Model
(DEM). The valley floor, into which the floodplain is incised, is defined by Pleistocene sediments. This unit was mapped as Quaternary alluvium by Sherrod and Smith (2000).

Simple metrics describing sinuosity, bed slope, channel width, floodplain width, valley bottom width, and the degree of confinement imposed by valley walls were calculated from the channel and floodplain maps and from a longitudinal profile developed from the 10-m DEM (fig. 2). Descriptions of channel-level classification (for example, pool-riffle, plane bed), were taken from previous studies and compared against aerial photographs and field observations.

\section{Historical Channel Mapping}

Digital maps of the channel were produced from aerial photographs for two periods, 1939 and 2005, to document net changes in channel conditions during the mid to late 20th century. Channel morphology was mapped from 1939 aerial photographs acquired from the U.S. Army Corps of Engineers, Portland District, and then scanned and rectified to the 2005 orthophotographs. The 1939 photographs encompassed only Reaches 2-12 (from the McKenzie Bridge to the Willamette River confluence). The 1939 and 2005 aerial photographs were taken during summer at relatively low discharges, facilitating the mapping of low-lying bars, alcoves, and other features. Daily mean discharge at the USGS streamflow-gaging station at Vida (14162500) ranged from 2,100 to 2,300 $\mathrm{ft}^{3} / \mathrm{s}$ during the July to August dates of the 2005 photographs, and was slightly higher (3,100 ft³/s) on May 31, 1939, when the 1939 photographs were taken.

The photographs from 1939 and 2005 were used to map active gravel bars (defined as bars greater than $700 \mathrm{yd}^{2}$ in area, with less than 25 percent vegetative cover) and channel features. Channel features were characterized by digitizing centerlines along the primary channel, as well as secondary channel features, which included side channels and alcoves that were at least partially wetted and located within the active channel. Although other "dry" channels were evident in the aerial photographs, only channels that were at least partially wetted were mapped in order to definitively characterize offchannel habitat that would be inundated during high streamflows. This mapping protocol undoubtedly underestimates the actual length of offchannel habitat available during high streamflows, but it nonetheless provides a repeatable, screening-level indication of offchannel habitat availability in each of the study reaches. All mapping was conducted at a scale of 1:5,000 with a goal of characterizing broad-scale differences in the availability of gravel bars and offchannel habitat. 
A major limitation to this reconnaissance-level analysis is our reliance upon two sets of channel maps. Ideally, aerial photographs from multiple, relatively narrow time intervals would be used so as to better link channel adjustment with specific drivers of channel change. For example, the role of floods could be evaluated by assessing pre- and post-flood photographs. Here, however, the net channel change is evaluated across a 65-year period in which the channel experienced numerous, overlapping, natural and anthropogenic disturbances. Major anthropogenic effects to the river basin between 1939 and 2005 include dam construction, bank stabilization, timber harvest, conversion of riparian forests to agriculture and development, and improvement of Highway 126 along the McKenzie River. Many floods of varying magnitude also occurred between 1939 and 2005, with several large floods occurring in the 1940s and 1950s; the largest recorded flood occurred on December 22, 1964, and a more recent, but much smaller flood event on February 7, 1996 (fig. 7).

The 1939 channel maps document a fluvial system that had already been subject to anthropogenic influences for nearly 100 years, although the magnitude and extent of these early effects (which included construction of the Leaburg and Walterville diversions as well as channel clearing, bank stabilization, timber harvest, and land conversion) probably had less of an effect on channel conditions than the larger-scale effects experienced in the mid to late 20th century. Furthermore, the 1939 channel characteristics were influenced by the numerous small floods that occurred in the 1920s and 1930s (fig. 7), and may also be a result of the exceptionally large regional floods that occurred in 1881 and 1890, and possibly even the largest known historical flood, which occurred in 1861.

\section{Specific Gage Analysis}

To assess the vertical stability of the channel bed at various sites in the study area, specific gage analyses were conducted at eight streamflow-gaging stations. The specific gage analyses followed the methodology of Klingeman (1973), using rating curves from USGS streamflow-gaging stations to plot the temporal variation in stage (water elevation) for a particular discharge. For each of the eight stations, five discharges were selected representing relatively low streamflows (75- and 95-percent exceedance), mid-range streamflow (50-percent exceedance) and high streamflows (5-percent exceedance and 2-year flood discharge). A measured stage for a particular discharge that is relatively constant over time indicates little net change in the cross-section geometry at a station, whereas large changes in the stage-discharge relation can indicate changes in cross-sectional geometry. When evaluated within the context of multiple discharges spanning a range of streamflow conditions and when the site characteristics are well documented, the specific gage curves can be used to infer potential deposition or incision and to indicate the overall susceptibility of the site to changes in channel geometry. The locations of streamflow-gaging stations are not necessarily representative of reach-scale conditions because these sites are selected for their relative stability. Hence, there is potential for a "false" observation of vertical stability, when an observation of instability should be "true."

\section{Factors Governing the Distribution of Key Habitat Types}

The selection of key habitat types (pools, off channels, bars, and floodplains) in the analysis was based on the life history stages of the nine exemplar species that were used. A similar approach was used by Gregory and others (2007a) for the Coast and Middle Fork Willamette Sustainable Rivers Project study.

\section{Pools}

Pools are formed either freely by the interaction of channel form and streamflow that drive secondary currents and sediment transport or forced by obstructions such as bedrock, boulders, and large wood (singularly or as debris jams) (Montgomery and others, 1995). Accordingly, the primary factors controlling pool dimensions and frequency include streamflow magnitude, sediment load, large wood and other streamflow obstructions, channel geometry, and bed material size (Buffington and others, 2002). Pools generally increase in size with increasing discharge along the length of a river. Steeper, coarser grained reaches often have smaller pool volumes than lower gradient, finer grained reaches (Wohl and others, 1993; Buffington and others, 2002). Because pools typically are alluvial features scoured from bed material, they can be highly sensitive to sediment supply and bed-material characteristics. If sediment supply exceeds transport capacity, then aggradation may result in diminished pool depth (Lisle, 1982). However, a sharp reduction in sediment supply can reduce pool frequency and depth because pool geometry will be limited by the thickness of deposited alluvium (Montgomery and others, 1996). Furthermore, reductions in sediment supply and large wood can substantially reduce pool frequency because channel-spanning blockages of large wood and sediment are a dominant pool-forming mechanism. For example, Montgomery and others (1995) report that in forested streams up to $100 \mathrm{ft}$ wide, 73 percent of the pools were forced by large wood, 18 percent were self-forming, and the remaining 9 percent were formed by boulders and bedrock outcrops. 
Deep pools provide habitat; depths greater than about $2 \mathrm{ft}$ provide cover for fish, amphibians, and mammals, and additional cover can be provided by large boulders, overhanging vegetation, undercut banks, or large wood. Large, deep pools with abundant cover are important habitats for many aquatic species and can significantly increase the carrying capacity of rivers and streams (Murphy and Meehan, 1991; Montgomery and others, 1995). Bjornn and Reiser (1991) cite literature showing that when large wood was removed from a stream, Coho salmon production declined coincident with a decrease in the number and size of pools, whereas the average water velocity increased.

Multiple studies have documented historical declines in the frequency and size of pools that can be related to reductions in pool-forming structures, including loss of large wood (Sullivan and others, 1987; Meehan, 1991). Channel clearing and snag removal for navigational purposes is well documented for the mainstem Willamette River (Sedell and Froggatt, 1984), but channel clearing by private landowners also occurred along the McKenzie River and its tributaries (Minear, 1994). As large wood was systematically removed from the river channel, riparian forests were repeatedly harvested, and downed and standing wood was selectively removed from proximal roads, which reduced wood recruitment. Inputs of large wood to the mainstem river were further reduced through the construction of dams along the Blue River and South Fork McKenzie River, and in the upper McKenzie River basin. The USACE flood control dams substantially diminish peak streamflows, which reduces opportunity for wood recruitment by way of bank erosion. Furthermore, the EWEB dams in the upper McKenzie River basin and USACE facilities trap large wood, which along with other factors, lessens the volume of wood entering downstream reaches (Stillwater Sciences, 2006b; U.S. Army Corps of Engineers, 2007; National Marine Fisheries Service, 2008b).

Pool depth can be diminished by sedimentation, which can be exacerbated by land management activities that include forest harvest and road building (Megahan, 1982). Numerous studies document channel aggradation in northern California streams following extensive hillslope erosion triggered by the December 1964 flood (Hickey, 1969; Kelsey, 1980; Lisle 1981). Such erosion and re-deposition can result in diminished pool-riffle morphology (for example, Lisle, 1982). However, the McKenzie River generally supports high sediment transport capacities relative to sediment supply (Lignon, 1991; Stillwater Sciences, 2006b); therefore, the potential role of aggradation on reducing pool complexity must be evaluated on a reach-by-reach basis by considering the local balance of sediment availability versus transport capacity, because in some locations, the regulated, post-dam streamflows might be insufficient to scour and maintain deep pools.

\section{Aquatic Offchannel Habitat}

Offchannel habitat, which includes side channels, alcoves, sloughs, and backwaters, are important habitat components for a large variety of species and life stages and is often critical for juvenile and rearing fish. These habitats provide refuge from high velocity waters, particularly during high streamflows in winter, and refuge from predators. They also provide important food resources because of their habitat complexity and their natural abundance of overhanging and riparian vegetation. Offchannel habitats are used extensively by Oregon chub, juvenile salmonids, amphibians, and turtles.

The suite of riparian landforms that comprise offchannel habitats are most abundant along unconfined, alluvial river corridors, where the channel is more likely to experience meander migration and avulsions, as well as creation and maintenance of side channels. Through frequent shifting, new channels are created. Older channels, progressively filled with fine sediment, become inundated only during high streamflows, and eventually they are abandoned. The degree of channel dynamism and the overall vegetation characteristics of the floodplain and riparian corridor dictate the availability and diversity of offchannel habitats. Like other gravel-bedded rivers in the Pacific Northwest, the primary drivers of channel adjustment on the McKenzie River include floods as well as upstream inputs of sediment and large wood, which form obstacles to streamflow and hence trigger bank erosion (O’Connor and others, 2003). Meander migration into forested floodplains introduces additional large wood and sediment into the channel, which further enhances channel shifting (Fetherston and others, 1995; Abbe and Montgomery, 2003; O’Connor and others, 2003).

Reaches that are most likely to support these processes, and hence also support a diverse array of offchannel habitat features, typically have unconfined active channels situated within a relatively wide forested floodplain, which maximizes opportunities for meander migration and side-channel formation. A wide alluvial corridor also helps to ensure that the channel is flowing through erodible bank materials that support high rates of meander migration and avulsions (Wallick and others, 2006). Artificial bank hardening through the construction of revetments can substantially diminish channel shifting and habitat complexity, particularly when large tracts of the alluvial corridor have been revetted (as documented on the Willamette River by Gregory and others, 2002a, and Wallick and others, 2006). Naturally occurring "hard" features such as bedrock outcrops can also exert a stabilizing influence when present for longer reaches (the scale of one or more bends), but when isolated bedrock outcrops are located within an otherwise alluvial reach, they can potentially contribute to overall habitat complexity by establishing forced pools (Montgomery and Buffington, 1997). 
Healthy native riparian vegetation is an important component of offchannel habitat because vegetation has beneficial effects on water quality, provides cover for wildlife and fish, traps sediment, increases stream shading (thereby reducing water temperatures), and provides food, nutrients, and organic matter to the stream (Murphy and Meehan, 1991; Johnson and Buffler, 2008). Riparian forests also can supply large wood to the channel, which creates jams that help force channel migration and provides important physical cover for various species, especially salmonids.

Floods are another key factor contributing to channel dynamism and the creation of offchannel habitat. Along the upper Willamette River, small to moderate-sized floods, in which streamflow is mainly confined within the active channel, have historically triggered rapid rates of meander migration, whereas exceptionally large floods have supported high overbank velocities carving meander-cutoffs and triggering numerous avulsions (Wallick and others, 2007). Hydraulic modeling and historical channel mapping also have shown that large historical floods were capable of creating and scouring secondary channels along the floodplain and high surfaces within the active channel, whereas smaller, controlled, post-dam floods (such as the February 1996 flood) inundated floodplain swales, but were only able to scour side channels along low-lying, relatively erodible surfaces within the active channel (Wallick and others, 2007).

\section{Alluvial Bed Features}

A wide variety of bedforms composed of gravel to cobble size sediments are found along the McKenzie River and other gravel bed streams. These bedforms include a diverse array of bar features, such as point bars and midchannel bars, as well as riffles and pools. Gravel bars are important ecologically because they provide newly created areas for vegetation colonization, enhance channel complexity, and promote hyporheic exchange (Dykaar and Wigington, 2000; Fernald and others, 2001). Submerged bedforms, such as riffles, can provide habitat for benthic macroinvertabrates and serve as spawning beds for salmon and trout (Kondolf and Wolman, 1993). In western rivers and streams, the highest diversity and productivity in benthic macroinvertebrates usually is in fast-flowing riffles with gravel to large cobble-sized substrate habitats (Minshall, 1984; Allan, 1995), such as those in McKenzie River basin.

The frequency of gravel bars and other alluvial bed forms is largely dictated by the interaction between the supply of coarse bed material (sediment supply) and the ability of the channel to transport and redeposit this sediment (transport capacity). Previous studies have shown a decreasing number and size of gravel bars downstream of dams, which is attributable to trapping of coarse sediment behind the dams and stabilization of formerly active bars because of reduction in peak streamflows and vegetation encroachment (Nadler and Schumm, 1981; Williams and Wohlman, 1984). In addition, depositional features require a unique set of hydraulic circumstances; for example, point bars form along the inside of bends, whereas midchannel bars typically form at channel expansions, and frequently occur upstream of obstructions to flow posed by boulders, large wood, or semistable islands. Activities that result in channel simplification (such as removal of large wood and bank stabilization) may ultimately promote a straighter planform, which can enhance transport capacity and diminish opportunities for bed material deposition. Furthermore, by limiting bank erosion, channel stabilization reduces local recruitment of sediments that could be remobilized into gravel bars and spawning gravels (Lignon and others, 1995).

Bed substrate frequently coarsens downstream of dams, as gravels and fines are winnowed from the bed, leaving the bed armored with coarse deposits of larger gravels (Dietrich and others, 1989). Bed coarsening decreases habitat availability for salmonids as they require certain size ranges of gravel to create spawning beds (redds): the median diameter of spawning gravels for smaller trout is approximately $15 \mathrm{~mm}$, whereas large salmon can utilize gravels up to $100 \mathrm{~mm}$ in diameter (Kondolf and Wolman, 1993). Another key factor determining the availability of suitable spawning habitat is the "looseness" of the cobbles and gravels composing redds. Fine sediment within the interstitial spaces can also negatively affect the diversity and production of benthic macroinvertebrates (Roy and others, 2003), decrease the supply of oxygenated water for eggs (Everest and others, 1987), and block fry from emerging from bed sediments (Tappel and Bjornn, 1983).

\section{Floodplain Habitat and Riparian Vegetation}

Floodplain surfaces are distinguished from the active channel by their age and relative elevation to the water surface. Whereas the active channel (and its various aquatic habitats) are inundated on an annual basis, floodplains represent a gradient of infrequently inundated, channel-adjacent surfaces constructed of sediment transported and deposited by the streamflow regime (Nanson and Croke, 1992). Along the lower McKenzie River basin, floodplain formation follows a similar trajectory as that of the upper Willamette River, whereby within-channel bar forms gradually aggrade and coalesce with older floodplain surfaces (Dykaar and Wigington, 2000). Along free-flowing alluvial rivers, a suite of geomorphic processes create a mosaic of different-aged surfaces at varying elevations, with each surface blanketed by distinct sediments according to its position relative to the channel (Ward and Stanford, 1983). 
The streamflow regime is superimposed upon this spectrum of surfaces, which can range from coarse gravel bars to rarely inundated floodplain swales, to establish a dynamic physical template for vegetation colonization and succession (Hupp and Osterkamp, 1985).

Channel shifting carves newly created surfaces out of older, established riparian plant communities, and hence increases patch heterogeneity. Multithread channels, such as in the historical lower McKenzie River basin, experience moderately frequent disturbances (in the form of meander migration and avulsions), and are more likely to maintain a mix of young and old surfaces, which in turn support higher levels of biological diversity than upslope habitats (Gregory and others, 1991; Beechie and others, 2006).

The habitats afforded by low-lying floodplain surfaces include wetlands, swales, and relict channels, as well as terrestrial communities composed of varying-age stands of riparian species (such as alder, cottonwood, and willow), whereas upland communities may be on the highest floodplain surfaces (Gregory and others, 1991). There has been extensive research on the numerous physical and ecological functions of riparian zones to their parent streams. For example, rarely inundated floodplain channels provide refuge for aquatic species during large floods, whereas low-lying, seasonal wetlands preclude the establishment of predatory species and provide important habitat for red-legged frogs (Kiesecker and Blaustein, 1998).

Factors that hinder floodplain formation and contribute to overall simplification of the riparian corridor include processes or direct actions that limit the connectivity between the active channel and floodplain, or minimize floodplain creation. For example, reduction of peak streamflows not only minimizes overbank deposition, but also reduces the processes that create and recycle floodplains (such as bar formation and bank erosion). Similarly, channel stabilization limits bank erosion, and contributes to planform simplification, which in turn slows the creation of bar forms that would eventually evolve into incipient floodplain. In addition to anthropogenic factors, there are inherent physiographic and geological controls on floodplain formation. Steep, highly constrained reaches support narrow floodplains, characterized by thin riparian communities which resemble upslope forests, whereas wide, unconstrained alluvial reaches are more likely to support broad, diverse floodplains with greater patch diversity (Gregory and others, 1991).

The life histories of riparian species depend upon the characteristic streamflow regime, that is., the timing and magnitude of streamflow, and hence can be negatively affected by streamflow regulation and diversions. Gregory and others (2007a) summarize the effects of altered streamflow on terrestrial vegetation in the Willamette River basin as follows:
- The magnitude of winter floods is reduced, which reduces floodplain inundation, sedimentation, and available bare soil for germination.

- The magnitude of summer low streamflow is increased, which can decrease regeneration and seedling survival by inundating low bars.

- The timing of the transition between winter high streamflow and summer low streamflows (recession) is shifted, which decreases survival of black cottonwood and other early successional-stage species.

- Alteration of streamflow magnitude and timing increases the potential for invasion of nonnative species, such as giant knotweed and reed canary grass.

Additional factors that diminish the abundance and diversity of riparian vegetation include land-use and channel stabilization. Vegetation maps produced by the 1851 General Land Office survey show that the McKenzie River floodplain historically supported an extensive deciduous forest composed of ash, red alder, big leaf maple, black cottonwood, white oak, and dogwood (Gregory and others, 2002b; dataset available from the Pacific Northwest Ecosystem Research Consortium (PNWERC) at http://www.fsl.orst.edu/pnwerc/ wrb/access.html, last accessed July 30, 2009). However, the area of riparian forests along major tributaries of the Willamette River basin declined by two-thirds between 1850 and 1990. The dominant floodplain landcover change has been the direct conversion of riparian forests and wetlands to agricultural lands (Gregory and others, 2002b). Even along floodplain areas of the mainstem Willamette River that were not converted to agriculture or developed areas, riparian vegetation communities have become increasingly homogenous and have decreased patch diversity (Dykaar and Wigington, 2000; Gutowsky, 2000; Fierke and Kauffman, 2005, 2006).

\section{Description of Channel Morphology and Habitat Limitation for Key Species}

The dominant factors controlling channel morphology and physical habitat vary for each reach of the McKenzie River. As a result, some reaches may be more prone to channel adjustment and reaches may be more sensitive to potential imbalances between sediment supply and discharge. Moreover, channel morphology and factors governing physical habitat availability will dictate whether environmental flows alone can achieve specific habitat goals for a reach, or if other factors (for example, sediment supply, bank materials, or large wood) must also be considered. 


\section{Upper McKenzie River Basin-Reaches 1 and 2}

\author{
Channel Morphology and Controls on Physical Habitat \\ Availability
}

The McKenzie River between McKenzie Bridge and Trail Bridge Dam (Reach 1) is a highly stable, predominantly single-thread stream with very few gravel bars. The channel morphology is largely a function of the geological history of the upper McKenzie River basin. The young High Cascades lava flows support a groundwater-driven hydrologic system, which leads to muted flood flows and low sediment yield rates (Stillwater Sciences, 2006b). The broad, glacially carved valley bottom is approximately $3-4$ times wider (about 1,500-2,000 ft) than the incised floodplain (about $500 \mathrm{ft}$ ), and is composed of coarse (bouldery) alluvium. Along Reach 1, the channel is narrow (reach average width is $141 \mathrm{ft}$ ), steep (rise/run slope is 0.0092 ), and confined within a relatively narrow floodplain that is only about three times wider than the active channel. The channel occupies a relatively straight and predominantly single-thread planform, with no visible gravel bars in the 2005 aerial photographs (table 20). Minear (1994) and Stillwater Sciences (2006b) determined Reach 1 to have plane bed morphology, characterized by featureless channel beds that lack bedforms (such as pool-riffle sequences or bars) and occurring at moderate to high gradients (Montgomery and Buffington, 1997). Channel and floodplain width increase substantially along Reach 2 , particularly below the confluence of Horse Creek, a large tributary draining the Western and High Cascades terrains. The channel adopts pool-riffle morphology along Reach 2, where reach average width increases to $316 \mathrm{ft}$, and slope diminishes to 0.0067 (table 20).

Channel planform is stable along Reach 1 , but becomes slightly more dynamic along the lower parts of Reach 2 (fig. 24). Although 1939 aerial photographs of Reach 1 were not available, Minear (1994) mapped historical channel change above McKenzie Bridge for the period 1949-1986 and detected little change in sinuosity and channel position, but did detect a 7,300 $\mathrm{yd}^{2}$ increase in gravel bar area. A specific gage analysis shows that the channel elevation at the USGS streamflow gage near Trail Bridge Dam (14168850) has been very stable for the period 1959-2008, indicating that the channel near the gage is not prone to substantial incision or aggradation (fig. 25). The major changes in this time period are associated with the December 1964 flood, when $0.5 \mathrm{ft}$ of deepening occurred, followed by about $0.5 \mathrm{ft}$ of aggradation between 1968 and 1971. From 1971 to 2008, gradual lowering was less than $0.5 \mathrm{ft}$, apparent at low to moderate streamflows $\left(580-1,700 \mathrm{ft}^{3} / \mathrm{s}\right)$, with little variation in stage for high streamflows $\left(4,600 \mathrm{ft}^{3} / \mathrm{s}\right)$.

Along Reach 2 the channel has largely remained in the same overall position between 1939 and 2005 with the exception of three avulsions. The two largest of these occurred at historically dynamic areas downstream of the Horse Creek confluence where the floodplain widens and the channel adopts a more sinuous path. An avulsion at Dearborn Island (RM 63) occurred during the December 1964 flood, whereas the avulsion at Delta Campground (RM 61) is associated with the 1986 high streamflow event (Minear, 1994). Although the avulsions decreased the centerline length, they increased the length of secondary channel features as both sites continue to experience meander migration and channel shifting. More side channels are in the 2005 aerial photographs than in the 1939 photographs (fig. 26A).

Deep pools in the upper McKenzie River basin typically form where the channel either impinges upon valley walls (which is the dominant pool-forming mechanism along Reach 1) or as a result of scour related to midchannel accumulations of sediment and wood (as observed at Delta Campground in the 2005 aerial photographs). Minear (1994) compared the frequency of large pools (greater than $6.5 \mathrm{ft}$ deep and $430 \mathrm{ft}^{2}$ in area) between historical habitat surveys in 1937-1938 and field observations in 1991. Along Reach 1, there was a 40-percent decrease in large pools, whereas a 60 -percent decrease was observed along Reach 2. Decreases in pool frequency along the upper McKenzie River basin could be a result of multiple causes, including reductions in large wood that are possibly associated with land management, reservoir storage, and channel clearing (Minear, 1994).

Sediment transport in Reach 1, and the distribution of alluvial bedforms, including gravel bars, is limited primarily by the inherent geology and hydrology of High Cascades terrain, but also is influenced by sediment trapping within the Carmen-Smith-Trail Bridge dam complex (Stillwater Sciences, 2006b). Field investigations have shown that the Pleistocene sediment composing the valley floor is much coarser than modern bedload, and remains in the channel as a coarse armor layer that can be transported only during extreme flood events (Stillwater Sciences, 2006b).

Although Western Cascades terrain comprises only 15 percent of the drainage basin above McKenzie Bridge, tributaries draining this terrain have high sediment yield rates and constitute the dominant sediment source to the McKenzie River (U.S. Forest Service. 1995; Stillwater Sciences, 2006b). The high sediment yield rates stem from a variety of mass-wasting processes, including deep-seated earth flows, debris flows, and debris slides. In contrast, the much more abundant High Cascades terrain is marked by low drainage densities and low sediment production, which supports groundwater-discharge dominated channels with little sediment transport. Although Trail Bridge and Smith Reservoirs trap 100 percent of coarse sediment entering from upstream, the overall rate of sediment capture is relatively low (approximately $478,400 \mathrm{ft}^{3}$ of sediment per year), which is roughly equivalent to one or two medium-sized gravel bars in the lower McKenzie River basin. Based on sediment budget calculations, tracer rock studies, and mapping of inchannel sediment storage Stillwater Sciences (2006b) concluded that the McKenzie River along Reach 1 was supply limited. 


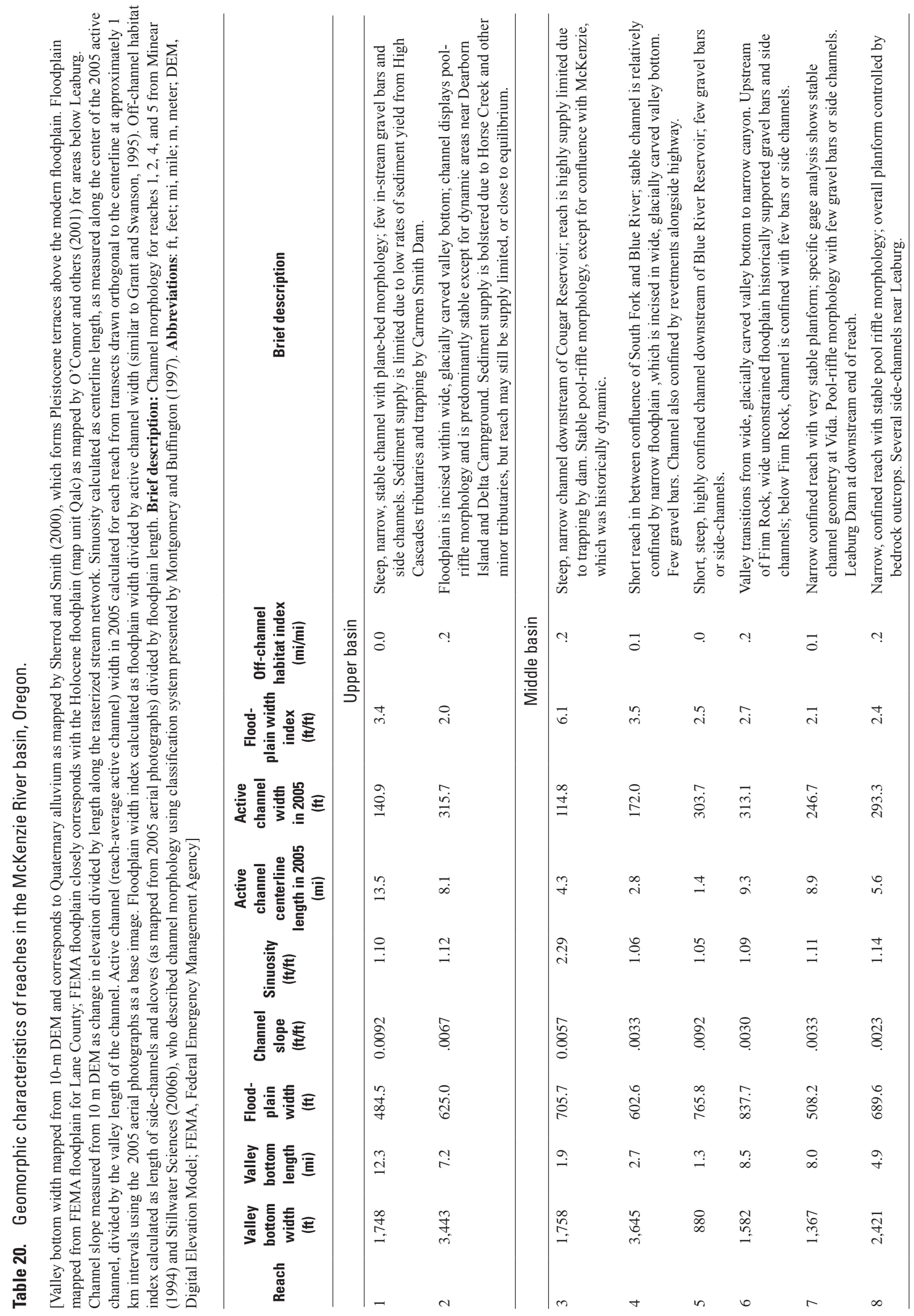




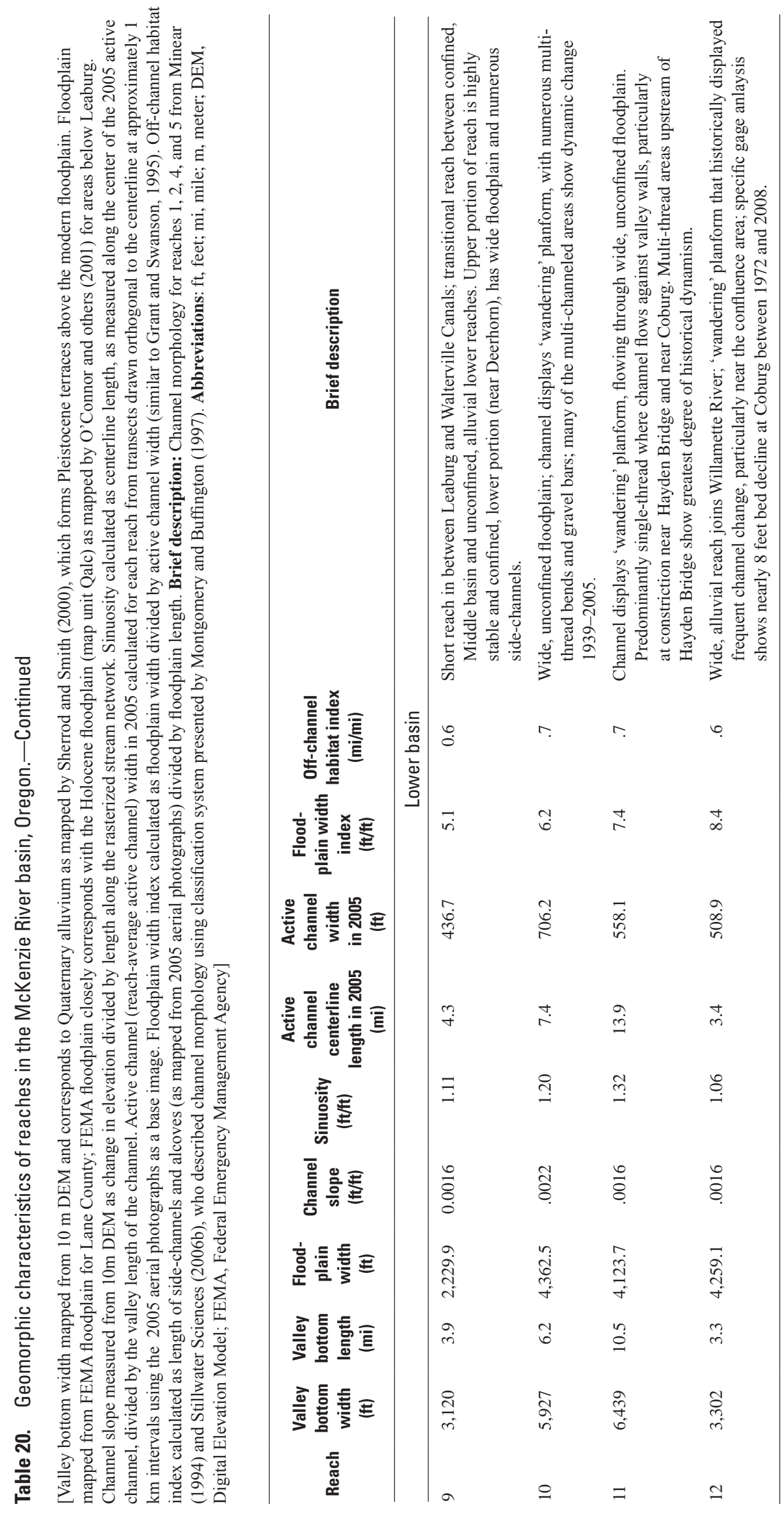



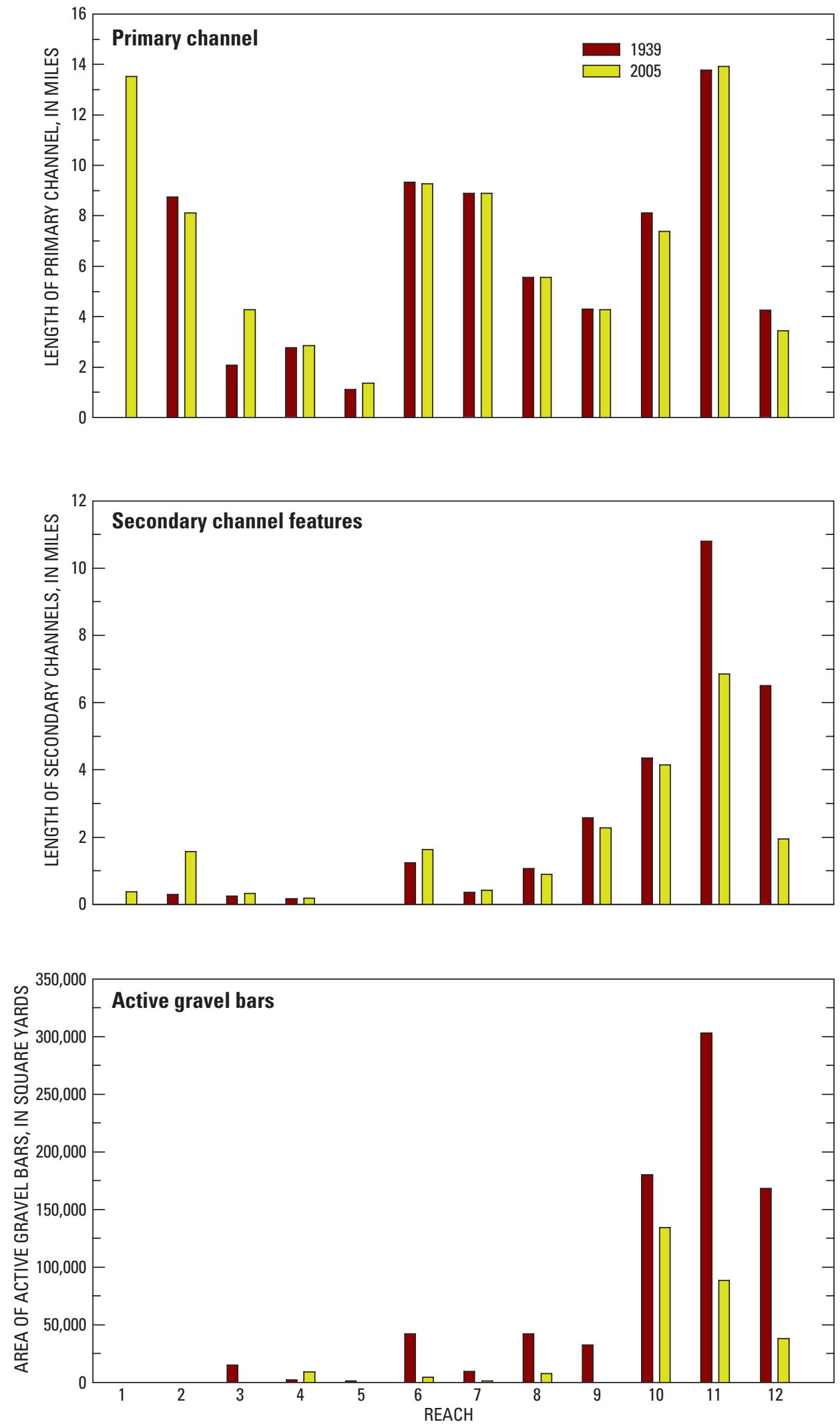

Figure 24. Study reach channel changes for 1939 and 2005, McKenzie River basin, Oregon. 
Reach 1: McKenzie River below Trail Bridge Dam USGS streamflow-gaging station No. 14158850

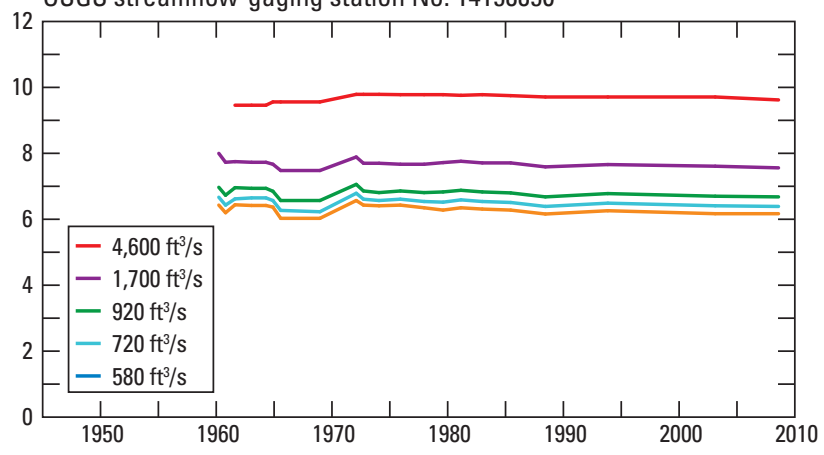

Reach 3: South Fork McKenzie River below Cougar Reservoir USGS streamflow gage \# 14159500

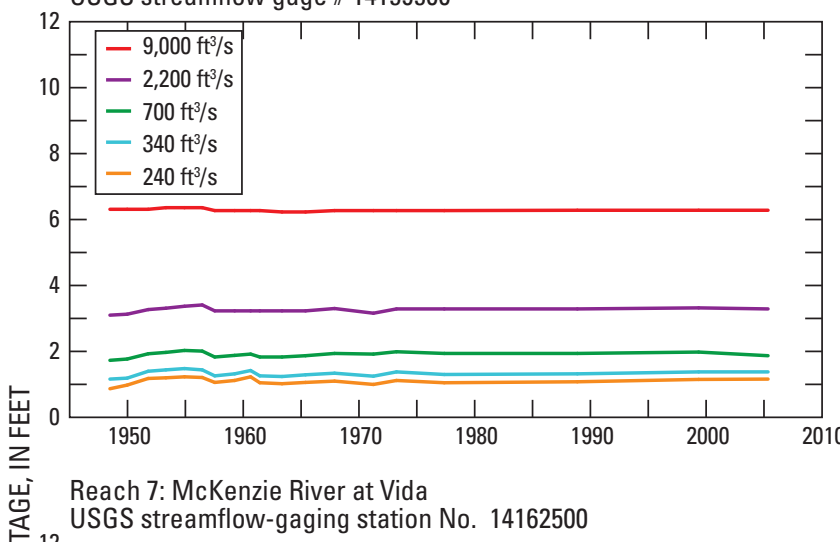

12

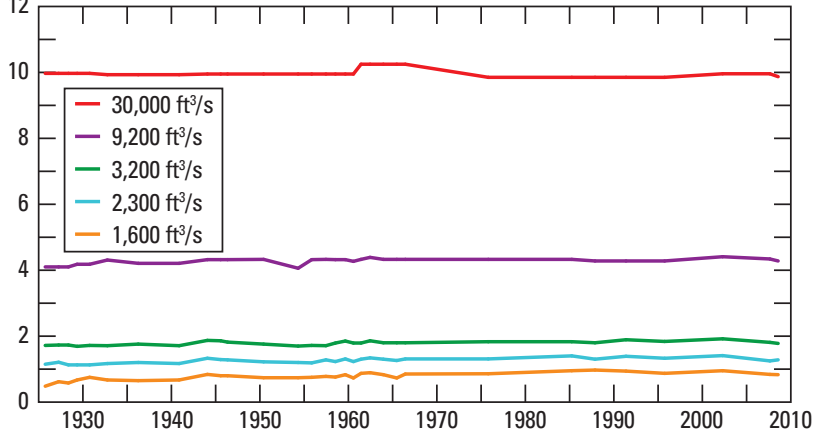

Reach 10: McKenzie River near Walterville USGS streamflow-gaging station No. 14163900

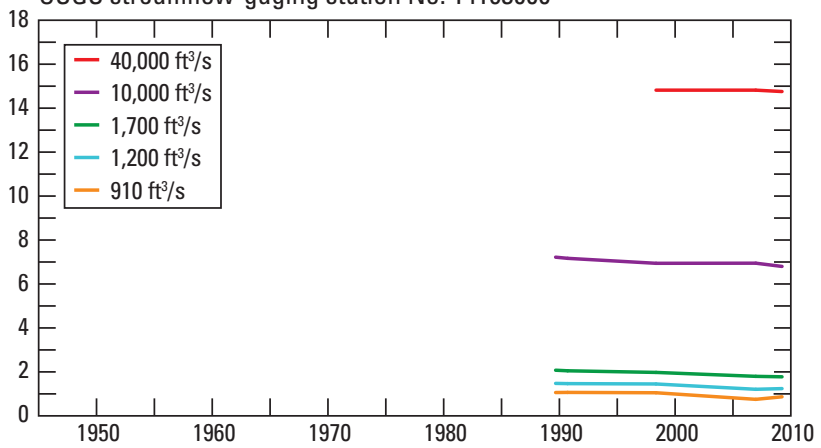

Upstream of Reach 3: South Fork McKenzie River 0.2 mi above Cougar Reservoir USGS streamflow-gaging station No. 14159200

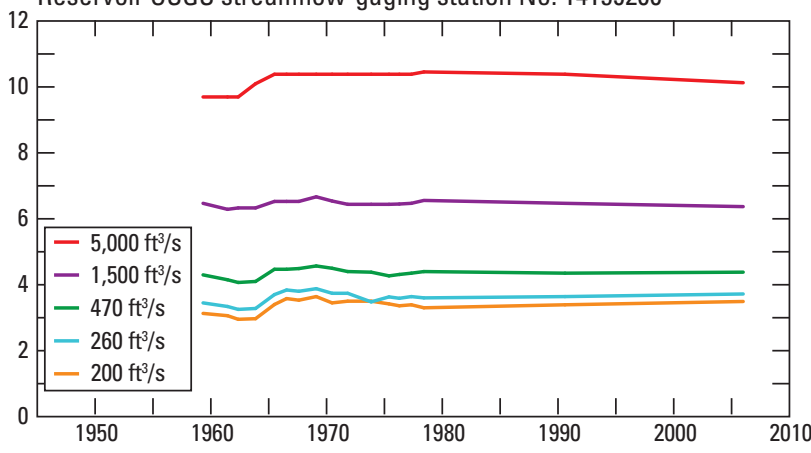

Reach 5: Blue River below Blue River Reservoir USGS streamflow-gaging station No. 14162200

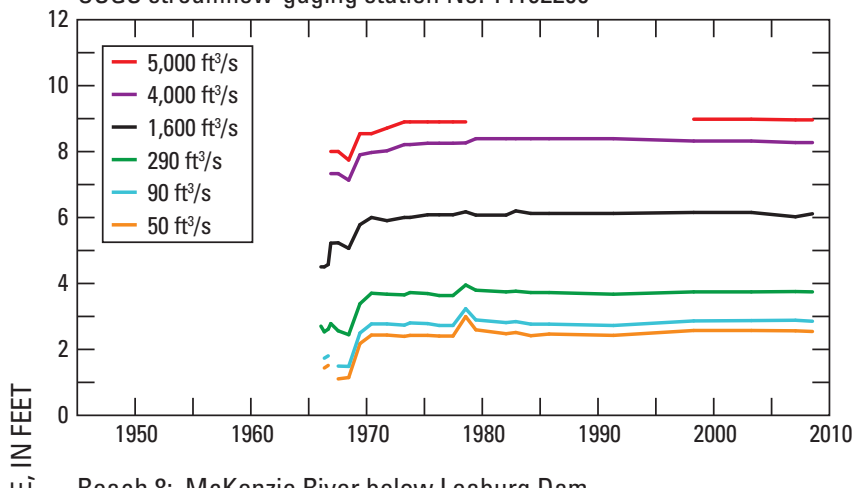

㟧 Reach 8: McKenzie River below Leaburg Dam USGS streamflow-gaging station No. 14163150

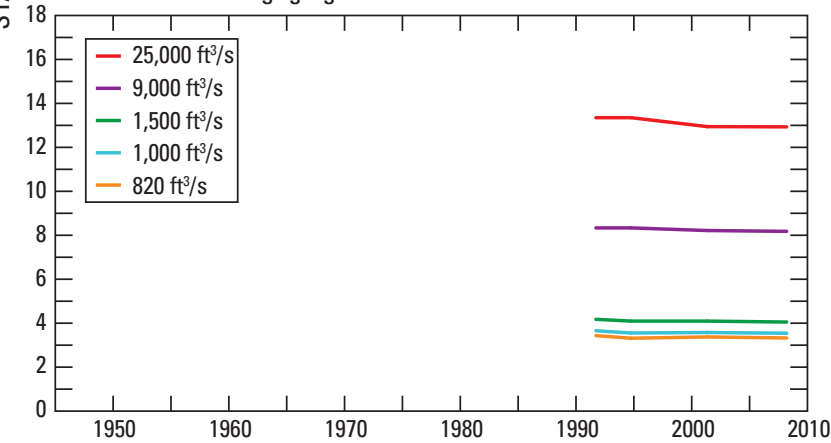

Reach 12: McKenzie River at Coburg USGS streamflow-gaging station No. 14165500

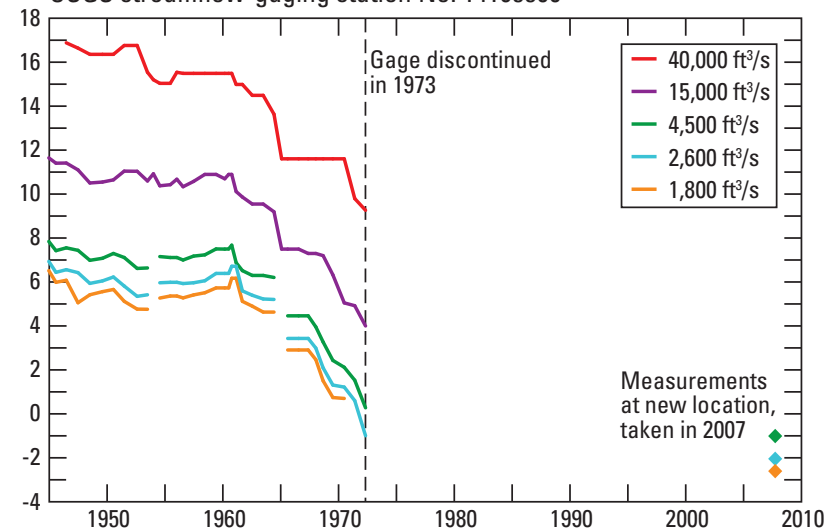

Figure 25. Specific gage analyses for selected study reaches, McKenzie River basin, Oregon. 


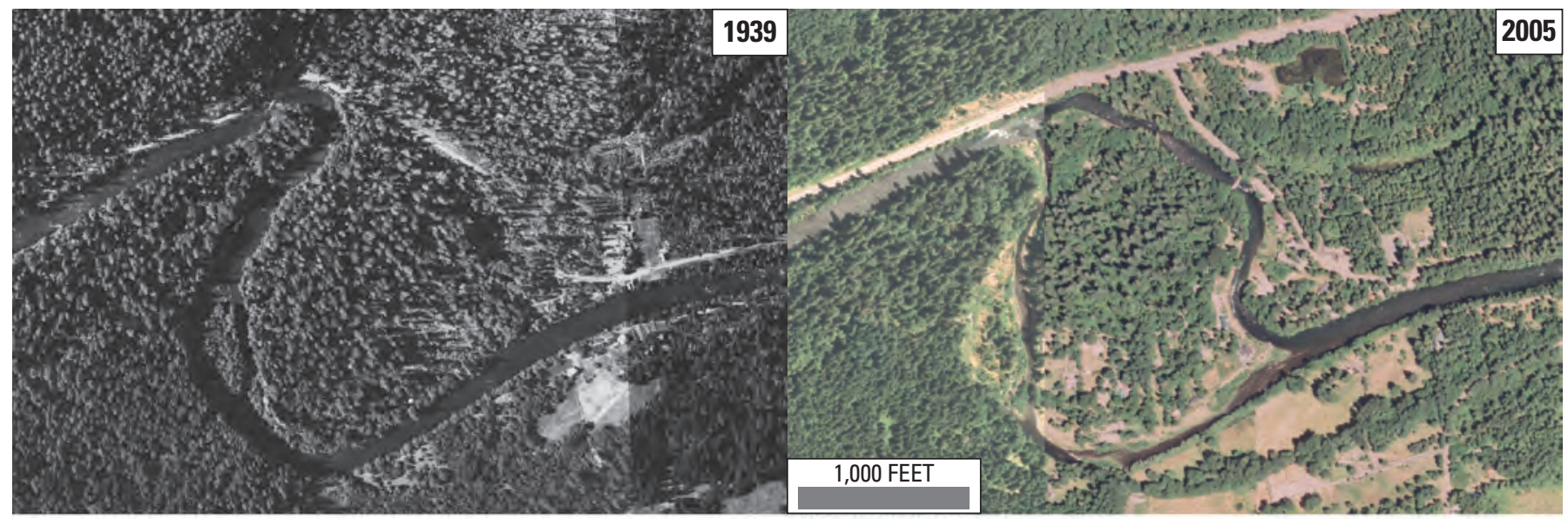

A. Avulsion at Dearborn Island, in upper McKenzie River basin (Reach 2). Other areas of this reach have been stable 1939-2005.

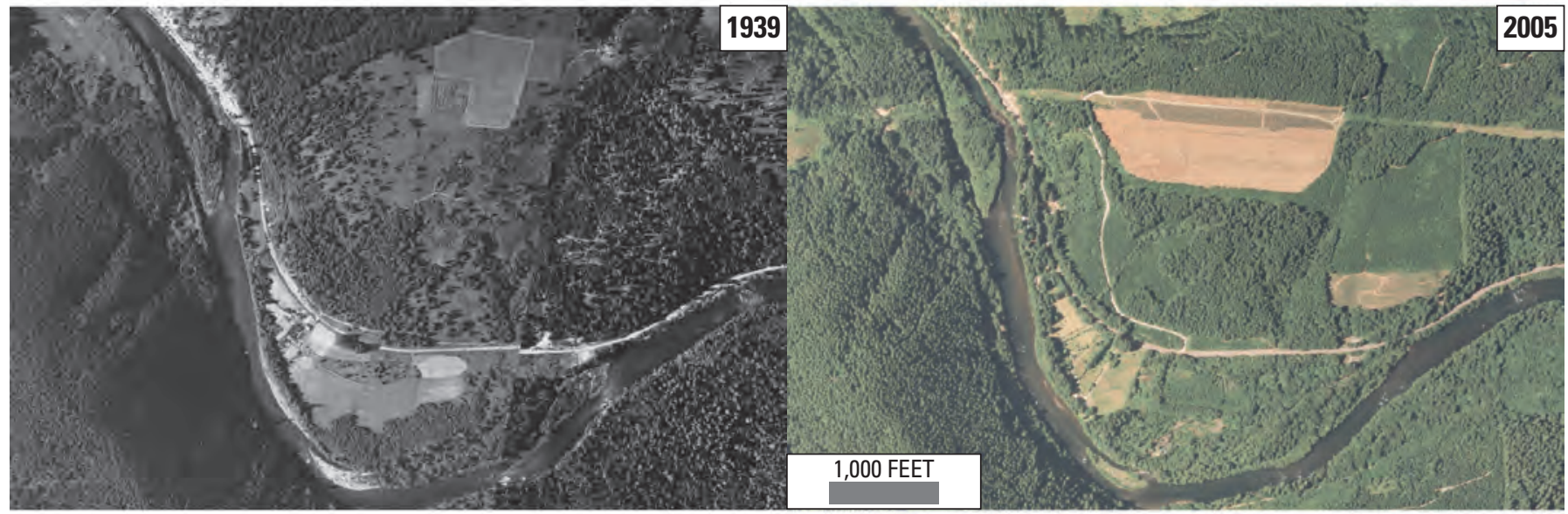

B. Example of stable planform along middle McKenzie River basin 2 mi above Vida (Reach 6).

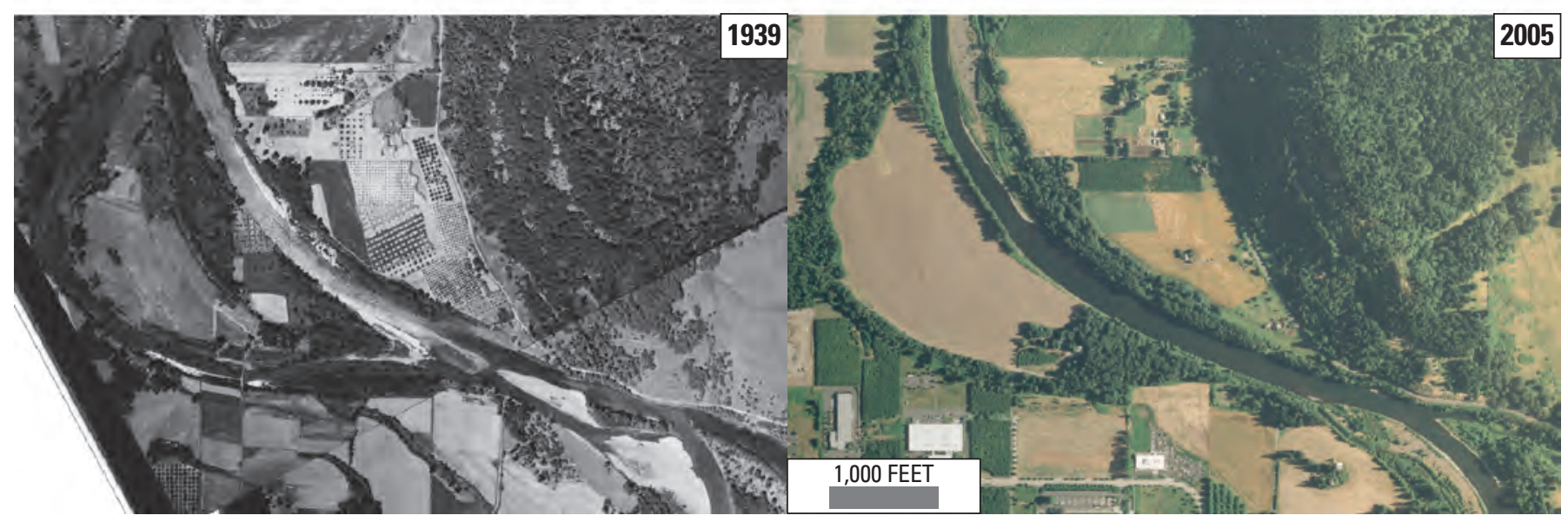

C. Example of bar stabilization and loss of secondary channels, lower McKenzie River basin (Reach 2), approx. $1.6 \mathrm{mi}$ above Cobura.

Figure 26. Channel changes at selected sites for upper, middle, and lower McKenzie River basin, Oregon, 1939 and 2005. 
The upper parts of the reach (downstream of Trail Bridge Dam) display strong supply limitation, while downstream areas with greater sediment contributions from Western Cascade tributaries were closer to equilibrium. Along Reaches 1 and 2, there were no large (greater than $700 \mathrm{yd}^{2}$ ) patches of bare gravel mappable from the 1939 or 2005 aerial photographs, which lends further evidence that any transportable sediment delivered to the channel is transferred to lower reaches during annual high water.

Offchannel habitat formation and maintenance along Reaches 1 and 2 are largely constrained by inherent geological controls. The steep gradient, narrow channel and relatively narrow floodplain along Reach 1 supports high sediment transport capacities that exceed the supply of sediment entering the reach. Although the terraces flanking the modern floodplain are largely composed of alluvial materials deposited during Pleistocene glaciations, these materials were deposited in a much wetter, higher energy glacio-fluvial setting. Hence, large floods such as those in December 1964 or February 1996 probably are required to remobilize local deposits of stored coarse sediments, but even these infrequent events are unlikely to trigger fundamental reach-scale changes in channel morphology. Lateral migration and side-channel formation are further restricted by revetment placed alongside roads.

It is unlikely that environmental flow releases from Smith and Trail Bridge Reservoirs would instigate reach-scale changes in side-channel formation, gravel bar frequency, or pool complexity because the overall channel morphology in Reach 1 is highly stable and subject to minimal alteration from large floods (figs. 24 and 25). However, gravel bar frequency in the lower gradient, downstream part of Reach 1 may possibly be increased if environmental flow releases coincide with natural or anthropogenic events that increase the supply of bed material (such as tributary inputs from large floods or gravel augmentation)and large wood. Environmental flow releases along Reach 2 are more likely than Reach 1 to create and maintain side-channels particularly along the lower gradient wider alluvial areas near Dearborn Island (RM 63). Changes at these sites are likely to be influenced by flood discharges and delivery of sediment and large wood from Horse Creek and smaller Western Cascade tributaries.

\section{Habitat Limitation}

The upper McKenzie River basin is home to the largest naturally spawning population of bull trout west of the Cascades, although they migrate seasonally downstream to the lower basin. The upper McKenzie River basin historically probably was not a predominant area for many of the other aquatic exemplar species, such as red-legged frogs, western pond turtle, Oregon chub, and brook lamprey because (among other reasons) these species rely upon secondary channel features which are sparse in the upper basin. Spring Chinook salmon are excluded from a part of their historical range in the upper McKenize River basin by Trail Bridge and Smith dams (National Marine Fisheries Service 2008b). Key habitat issues in Reaches 1 and 2 include an insufficient level of large wood (important for habitat formation such as pools and cover for fish) and spawning gravel, loss of rearing and spawning habitat (as a result of reservoirs and blockage posed by dams), and the reduction of large pools (National Marine Fisheries Service, 2008b).

Hydrologic alteration is not a primary issue for the aquatic/riparian ecosystem in the upper McKenzie River basin. The key habitat limitations in Reaches 1 and 2 include insufficient large wood and spawning gravel, loss of rearing and spawning habitat (as a result of blockage posed by dams), and the reduction of large pools (National Marine Fisheries Service, 2008b).

The 40-60 percent reduction in large pool habitat in the upper McKenzie River basin has potentially affected native fish production, particularly spring Chinook and bull trout, which depend on deep pools with cover. Rearing fish use pools, and fish abundance is closely tied to availability of cover provided by turbulence, large wood, overhanging vegetation, and depth. Adult fish frequently use pools as resting areas, to spend extended periods waiting for migratory or spawning environmental cues.

\section{Middle McKenzie River Basin-Reaches 3-8}

\section{Channel Morphology and Controls on Physical Habitat Availability}

The middle McKenzie River basin extends from the confluence of South Fork McKenzie River near the town of Blue River to the Leaburg Canal diversion dam (Reaches 4, 6,7 , and 8). The overall morphology and historical patterns of channel change along the lower parts of the South Fork McKenzie River (Reach 3) and Blue River (Reach 5) are similar to the mainstem McKenzie River.

The middle McKenzie River basin channel is moderately steep, with channel gradients varying from 0.0033 in Reach 4 to 0.0023 in Reach 8 (fig. 2, table 20). The town of Blue River (near the downstream end of Reach 4) marks the farthest advance of valley floor glaciations; hence, the valley bottom is wide above this point but narrows by more than 50 percent below Reach 4 (along Reaches 6-8). A relatively narrow floodplain (about 500-800 ft) is incised within this valley bottom, where the floodplain width is typically two to three times the width of the active channel (about $300 \mathrm{ft}$ ), although the ratio of floodplain to active channel width is highly variable depending on the width of the valley floor and the position of the channel relative to valley walls. In some areas, the channel is relatively confined, with floodplain width only slightly greater than active channel width (for example, Reach 7 near the town of Vida), although there are limited areas (such as Reach 4 above Finn Rock) where the floodplain is relatively wide, with several sinuous side channels in 1939 and 2005. 
The availability of offchannel habitat and secondary channel features is largely controlled by floodplain width and local valley floor constraints; in areas where the channel is highly confined, few side channels are in the 1939 or 2005 aerial photographs, but in wider, alluvial stretches, side-channel frequency increases. The middle McKenzie River basin is highly stable with little net change in its planform and secondary channel features from 1939 to 2005 (figs. 24 and 26B). A specific gage analysis conducted at the USGS streamflow gage near Vida (14162500) shows that cross-sectional geometry at the gage has been stable for the period 1925-2008, with lower discharges having virtually no variation in stage over time, and moderate to high discharges having a maximum variation in stage of only $\pm 0.3 \mathrm{ft}$ (fig. 25).

The number of large pools along the middle McKenzie River basin has decreased by approximately 35 percent between 1939 and 1991 (from data provided by Sedell and others, 1991, and Minear, 1994). Pools within the middle McKenzie River basin are primarily forced pools, which occur where the channel impinges on bedrock, making an abrupt turn. Although forced pools are still along the river, and the overall position of pool-riffle sequences is similar in the 1939 and 2005 aerial photographs, Minear (1994) report that the overall size and complexity of pools has diminished and attributes these changes to reductions in large wood (which historically provided cover) and reduction of peak streamflows (which historically scoured pools).

Along Reaches 6-8, there were large decreases (80-100 percent) of bare gravel bars mapped between 1939 and 2005 (fig. 24). Reach 4 shows an increase in gravel bar area mainly a result of the growth of a bar near the confluence with the South Fork McKenzie River. However, the magnitudes of the 1939 and 2005 Reach 3 gravel bar area are much smaller than those of Reaches 6-8. Bar losses along Reaches 6-8 were typically associated with vegetation colonization, which reduced the area of bare gravel. The bars in the 1939 photographs typically appear in the same locations as their 2005 counterparts, (and generally along wide areas of the floodplain), but the overall area of bare gravel in 2005 is diminished, and the area of vegetation has increased (fig. 26B). Minear (1994) report similar results when mapping gravel bars above Leaburg between 1945 and 1986. Decreases in bar area are probably in part a result of reduction of flood peaks (which has allowed vegetation to colonize and stabilize formerly active bar surfaces that were located along lower-gradient areas). Although not quantified, sediment supply presumably has diminished appreciably following construction of the USACE flood control dams which block the transport of coarse bed material from the historically sediment-rich tributaries of South Fork McKenzie and Blue River. Reduced sediment supply would limit bar building unless offset by inputs from other tributaries or bank erosion. Creation of new gravel bars is also limited by the channel and valley morphology as there is a paucity of low-velocity areas where gravels and cobbles can be deposited. Hydraulic modeling by Lignon (1991) showed that despite flow regulation, the steep, confined reaches of the middle McKenzie River basin continue to support high transport capacities that may exceed the current sediment supply. Supply limitation is also indicated by visual assessments of bed substrate from 1939 and 1991, which suggests that the bed material has coarsened in response to dam construction (Minear, 1994). Bed coarsening can have a direct effect on the availability of spawning habitat so that in many areas the particle size is too coarse for salmon spawning. The resulting reduction in supply of spawning gravel has led to redd superimposition, or redds being built on top of one another (Lignon and others, 1995).

\section{Habitat Limitation}

Historically, the middle McKenzie River basin was probably an important region for all nine exemplar species discussed in this report, although less for bull trout compared to the upper basin. In this region there are large tributaries such as Blue and South Fork McKenzie Rivers that would also have provided abundant habitat for spring Chinook salmon, lamprey, and potentially bull trout in the upper parts of these subbasins. The middle McKenzie River basin mainstem is an important area for spring Chinook salmon and lamprey. The floodplain and offchannel habitats in this region are also important for Oregon chub, red-legged frogs, western pond turtles, and key riparian vegetation species (cottonwoods, alder, willows, and other terrestrial species).

Key habitat issues and limiting factors include reduced recruitment of large wood and spawning gravel (as a result of blockages imposed by dams), loss of rearing and spawning habitat, alteration of natural streamflow and temperature regimes, and loss of instream, riparian, and floodplain habitats and/or complexity. The reduction in spawning habitat can be specifically related to a reduction in cobble/gravel recruitment caused by dams and channel and bank stabilization. Reduced high streamflow events (high streamflow pulses and small to large floods) affect channel and offchannel formation and maintenance. Aside from decreased flooding in the winter and spring, dam streamflow releases are typically elevated in the summer. In the late summer elevated streamflows can encourage spawning along the wetted channel margins. Later these locations can dry up if streamflow levels are not sustained throughout the incubation period. Dam streamflow releases in the summer are also unnaturally cooler, which can affect the timing of juvenile salmonid growth and outmigration.

The 35-percent reduction in large pools in the middle McKenzie River basin can negatively affect many species, particularly spring Chinook salmon, bull trout, and lamprey by decreasing available cover and habitat necessary for rearing and resting areas. Salmon typically stay under available cover and are less inclined to migrate during daylight hours. Daytime streamflow downramping at a dam can then severely affect fish if they become stranded in small disconnected pools or dry channel beds. 


\section{Lower McKenzie River Basin-Reaches 9-12}

Channel Morphology and Controls on Physical Habitat Availability

The McKenzie River floodplain below the town of Leaburg widens, occupying an alluvial corridor greater than $3,000-4,000 \mathrm{ft}$ in width from this point to its confluence with the Willamette River (fig. 27). The lower reaches of the McKenzie River have displayed the greatest degree of dynamism of all the study reaches; although there is little net change in historical channel position along much of the middle and upper McKenzie River basin, there historically have been more avulsions and a greater degree of lateral migration along Reaches 10-12.

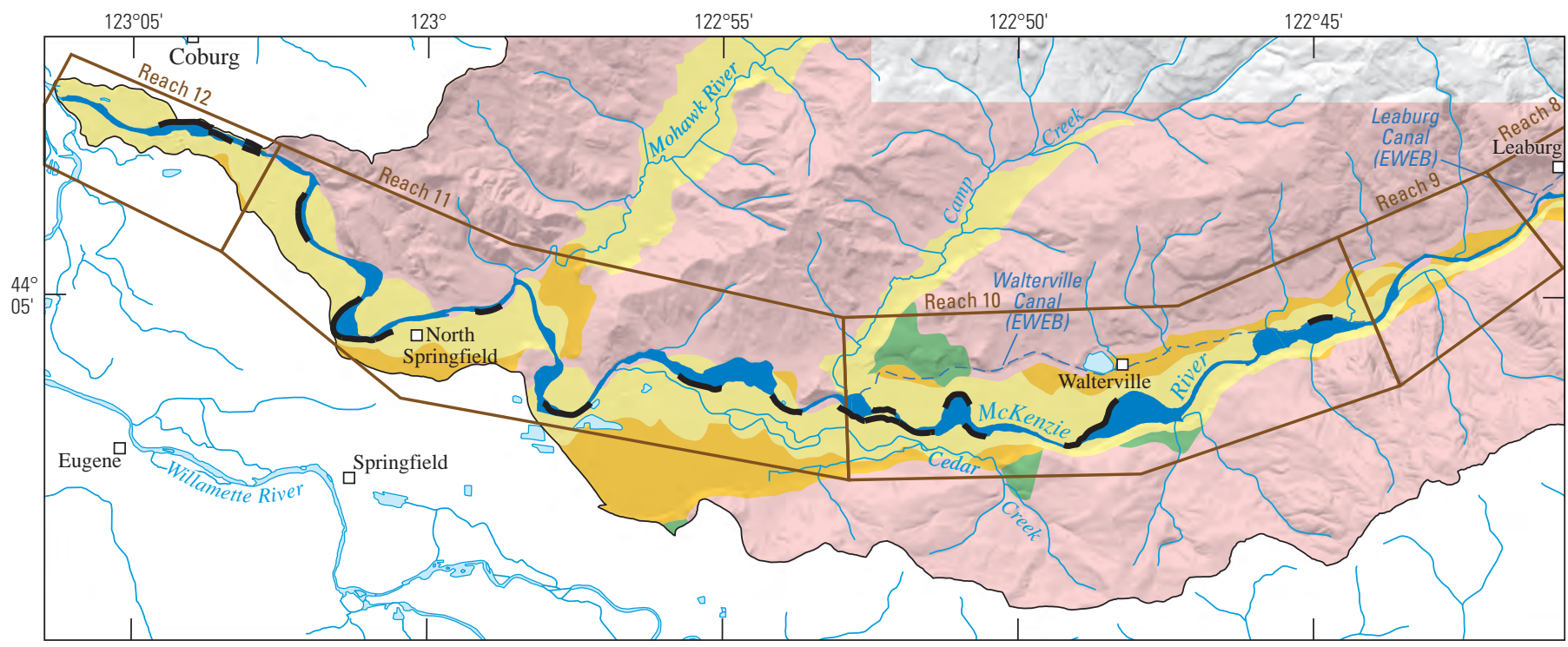

Base from Oregon Geospatial Enterprise digital data, various dates, 1:100,000. Universal Transverse Mercator Projection, Zone 10, North American Datum of 1983

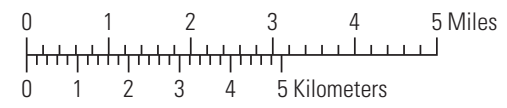

Geology modified from O'Connor and others (2001)

\section{EXPLANATION}

Geologic unit

Holocene alluvium

Pleistocene alluvium

Pleistocene terrace gravels

Western Cascades volcanics

MacKenzie River active channel—2005

Reaches

U.S. Army Corps of Engineers revetments

Figure 27. Constraints on channel change for the lower McKenzie River basin, Oregon. 
Channel planform in the lower McKenzie River basin is generally that of a "wandering gravel bed river" (Church, 1983). Wherein the channel is predominantly single threaded, but can also have multichanneled reaches. Historical surveys by the General Land Office (GLO) in the 1850s depict the channel along Reaches 9-12 as narrow, sinuous, and flowing through a dense riparian forest that extended throughout the Holocene floodplain (digital map produced by Pacific Northwest Ecosystem Research Consortium, 2002; and The Nature Conservancy and available at http://www.fsl.orst. edu/pnwerc/wrb/access.html, last accessed July 30, 2009). Between 1850 and 1939, there were at least seven avulsions along Reaches 10,11, and 12 that resulted in the abandonment of large-amplitude bends. Avulsions were often coupled with rapid migration along adjacent bends, as multiple locations show the enlargement and downstream migration of bends. Along the nearby Willamette River, numerous avulsions also occurred during the large regional floods of the late 19 th century (particularly the 1861 flood of record), whereas rapid meander migration was dominant from the 1890s to 1930s, (a period in which there were frequent small floods) (Wallick and others, 2007). The lower McKenzie River basin probably followed a similar trajectory of change until the onset of flood control and channel stabilization in the mid20th century. Many of the areas along the McKenzie River that displayed meander migration, side-channel shifting, and avulsions historically were bordered by more erodible Holocene alluvium that has been subsequently stabilized with revetment. In contrast, bends that impinge upon resistant valley walls (composed of Tertiary volcanics) have generally remained stable between 1850 and 2005, with little net change in position (fig. 27).

Between 1939 and 2005, there have been large reductions in the length of secondary channel features and abundance of active gravel bars (fig. 24). Several of the large, semistable islands in the 1939 photographs appear increasingly stabilized by vegetation in the 2005 aerial photographs, and the historically active side channels that once separated these islands from the floodplain appear less distinct (fig. 26C). Despite these reductions, many relict secondary channel features are still present within the active channel and floodplain. Large decreases in the area of active gravel bars have occurred: Along Reach 9 in 1939, seven bare gravel bars, as well as other, much larger unmapped bars had greater than 25-percent vegetation cover; by 2005, these bare gravel bars had either disappeared entirely, or were covered in mature tree canopy, resulting in a 100-percent decline in the mapped area of bare gravel bars along Reach 9. Reach 10 had a 25 percent decrease in gravel bar area, and Reaches 11 and 12 had a greater than 70-percent loss of bare gravel (ig. 24).
The abundance of gravel bars in the 1939 aerial photographs, and particularly the appearance of numerous "bare” gravel features along point bars and side channels, and at the heads of islands, indicates that these alluvial features were created and remobilized on a frequent basis. The large decrease in the area of bare gravel bars between 1930 and 2005 is presumably a result of a combination of factors, including (1) vegetation encroachment and stabilization because of reduced peak streamflows, (2) decreased sediment supply resulting from trapping of coarse sediment by dams, (3) decreased recruitment of local sediment sources because of dampened bank erosion rates resulting from flood control and bank stabilization, and (4) reduction in the number of low-velocity, depositional areas as a result of channel narrowing and simplification following vegetation encroachment and bank stabilization.

In addition to losses in secondary channel features and gravel bars, the lower McKenzie River basin between reaches 9 and 12 had a 63-percent decrease in large pools between 1939 and 1991 (Sedell and others, 1991). Historically, the main pool-forming agents along these dynamic, alluvial reaches would presumably have been inchannel obstructions (for example, midchannel bars or islands) that are enlarged and stabilized by large accumulations of wood, triggering scour and pool formation (for example, Montgomery and others, 1995; O’Connor and others, 2003). Pools also would be expected where the channel impinges upon Tertiary valley walls and possibly where the channel flows against older, more indurated (difficult to erode) bank materials at the base of Pleistocene terraces. Reductions in pool frequency are most likely a result of an overall decrease in pool-forming agents, namely gravel bars and large wood, which are not only dependent upon an ample supply of bed material and wood, but also require sufficiently high streamflows to form the channel-spanning obstructions and scour the resultant plunge pools.

Determining the relative importance of sediment supply versus transport capacity would require quantitative analyses that include development of a sediment budget and modeling of transport capacity for a variety of streamflow scenarios, which were beyond the scope of this project. Previous work by Lignon (1991), however, indicates that transport capacities in the lower McKenzie River basin are sufficiently high to transport available sediment. If this is the case, then trapping of coarse gravels by dams may be a factor in the decrease of total gravel bar area in addition to other factors, such as reductions in local recruitment and the stabilization of formerly active bars. 
A specific gage analysis at USGS streamflow gages near Coburg (14165500) (Reach 12) shows substantial lowering of stage for all streamflows, indicating a net lowering of the streambed elevation by approximately $8 \mathrm{ft}$ (fig. 25). Much of this lowering occurred in the period after the December 1964 flood and prior to 1972 when the gage was discontinued. Measurements by the USGS in October 2007 indicate that incision slowed during 1972-2007, but that the channel continued to degrade by a total of about $2 \mathrm{ft}$. Klingeman (1973) attributed bed degradation at Coburg to several possible causes, including commercial sand and gravel removal downstream of the gage and the presence of a historic irrigation dam that may have artificially stabilized the streambed until the pilings in the dam were destroyed. Another possible contributing factor to the channel lowering is a series of avulsions that occurred downstream of the gage at the site currently occupied by a sand and gravel mining operation. The avulsions occurred sometime between 1939 and 2005, and likely are attributable to the December 1964 flood. By locally increasing channel slope, these avulsions may have triggered an upstream migrating knickpoint that traveled upstream to the Coburg gage (as described on other rivers by Kondolf, 1997). A specific gage analysis conducted 20 mi upstream from Coburg at the USGS streamflow-gaging station near Walterville (14163900) (in Reach 10) shows that the channel geometry has been stable during the 11 years that the gage has been operational (1989-2009) (fig. 25). The Walterville gage is located at a stable location where the channel flows against the valley wall and has experienced very little shifting between 1939 and 2005.

Bed degradation can potentially be problematic from a floodplain restoration perspective because, as the channel bed incises, the discharge required to overtop the banks increases. Thus, the 2-year recurrence interval, or "bankfull flow" may not inundate the floodplain, and could lead to further bed scouring. Additional work is needed to determine the extent of incision in the vicinity of the Coburg gage, and to ascertain whether the bed lowering at the gage is indicative of systematic reach-scale incision in the lower McKenzie River basin. Field observations by biologists in the McKenzie River basin indicate that local incision at various points throughout the lower McKenzie River basin is potentially associated with avulsions through gravel mining pits and meander cutoffs triggered by floods (Greg Taylor, U.S. Army Corps of Engineers, and Andrew Talabare, Eugene Water and Electric Board, oral commun., 2009). Lignon (1991) also documents local incision on the order of $1-5 \mathrm{ft}$ occurring downstream of Leaburg Dam. However, widespread incision may be limited by bedrock outcrops and other "hard points" that exert vertical control on channel elevations (Greg Taylor, U.S. Army Corps of Engineers, and Andrew Talabare, Eugene Water and Electric Board, oral commun., 2009).

\section{Habitat Limitation}

In addition to serving as a migration corridor for salmonids and lamprey, the lower reaches historically were probably most important for key floodplain and offchannel riparian species such as red-legged frogs, turtles, and Oregon chub.

Like the middle reaches, key habitat issues for the lower McKenzie River basin include reduced recruitment of large wood and spawning gravel, loss of rearing and spawning habitat, alteration of natural streamflow and temperature regimes, and loss of instream, riparian, and floodplain habitats and/or complexity. Reduced high magnitude streamflow (high streamflow pulses, small and large floods) affect channel formation and maintenance, instream and offchannel habitats, riparian structure, and habitat complexity and diversity. Bank stabilization with the use of revetments is also a factor in the reduction of channel complexity in the middle and lower reaches.

As with the upper and middle reaches, large-pool habitat in the lower McKenzie River basin has decreased. There also has been a significant loss of secondary channels (36-70 percent) and bare gravel bar area (25-100 percent), which are important for a number of native species, including juvenile salmonids (particularly during overwintering periods), Oregon chub, western pond turtle, and red-legged frog. Bare gravel bars that are inundated during fall or spring flows are potentially important spawning areas for Chinook salmon or other native species.

Aerial photographs of the lower McKenzie basin show that by 1939, much of the historical floodplain forest depicted in the 1850 s GLO vegetation maps already had been converted to agriculture (fig. 28). Between 1939 and 2005, increases in riparian forest canopy occurred on some areas of the floodplain (including formerly logged areas as well as historically active, nonvegetated bar surfaces), and other areas experienced declines in native vegetation (typically where floodplain forest had been converted to gravel pits or agriculture). In general, however, large (greater than 50 acres) patches of riparian forest are still present, particularly along more dynamic areas of the channel that are unsuitable for agriculture or development. Nonetheless, black cottonwoods and mature alders are currently dying in large numbers along the lower reaches of the river, which may be related to channel incision and subsequent declines in the water table elevation (Greg Taylor, U.S. Army Corps of Engineers, and Andrew Talabare, Eugene Water and Electric Board, oral commun., 2009). Recent cottonwood and alder recruitment does not appear to be sufficient to replace the dying trees, which is similar to findings for the mainstem Willamette River, where young black cottonwoods are unable to replace mature stands (Dykaar and Wigington, 2000). Another explanation for the lack of new recruitment of riparian trees may be the significant reduction in bare ground within the active channel and floodplain, as a result of the reduction in bare gravel bars. 


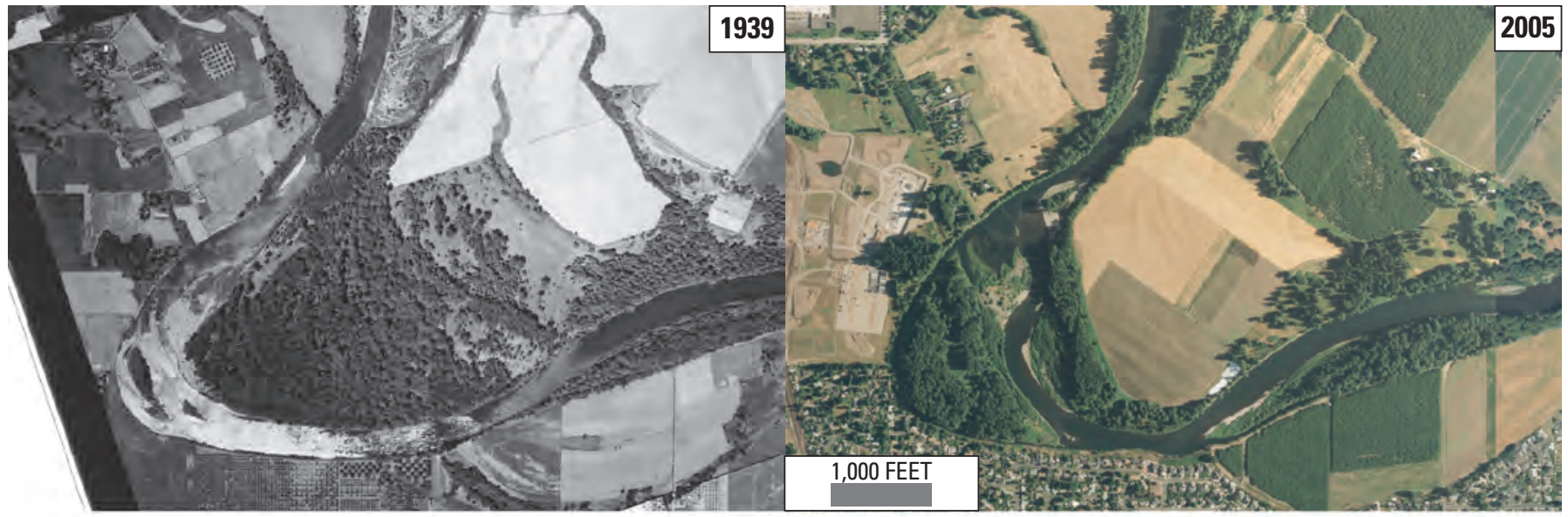

A. Reach 11, 3.8 miles below Hayden Bridge.

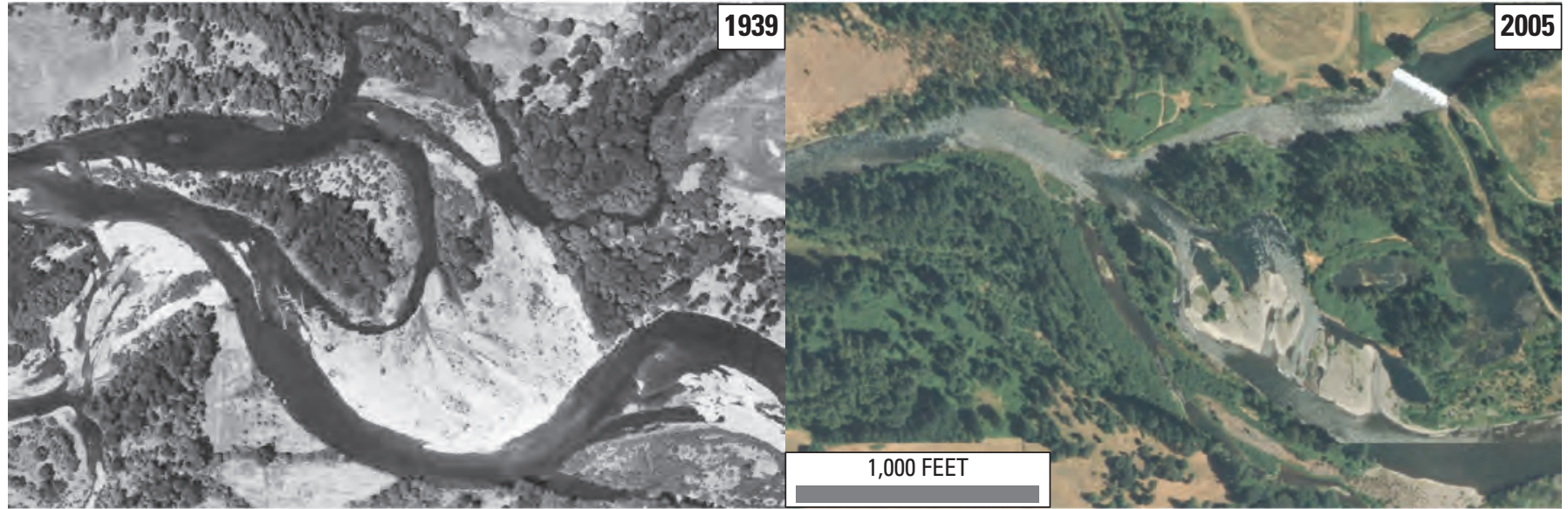

B. Reach 11, downstream end of Walterville Canal.

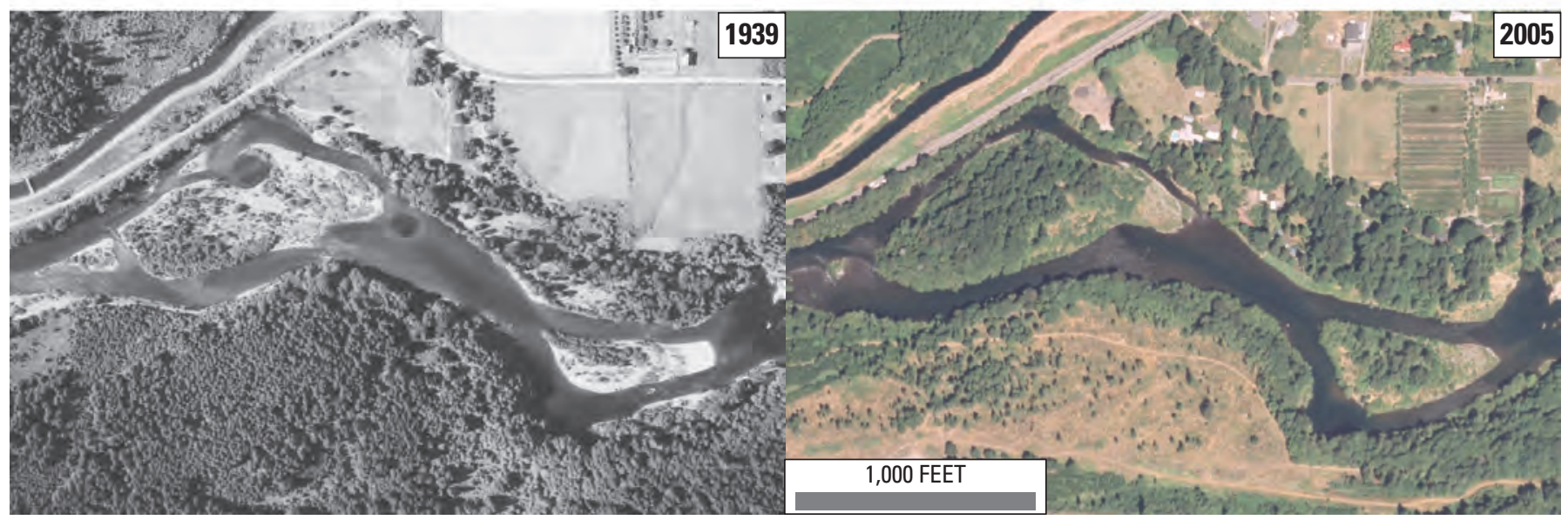

C. Reach 8, 3.3 miles below Leaburg Dam.

Figure 28. Changes in flood-plain vegetation in the lower and middle McKenzie River basins, Oregon, 1939 and 2005. 


\section{Relations Between Streamflow, Geomorphology, and Ecology}

\section{Key Elements}

- Channel morphology and habitat availability depend on the "effective discharge," (or channel-forming flow typically equivalent to or slightly greater than bankfull discharge), as well as the magnitude, frequency, and timing of less frequent flood events.

- The ability of the channel to respond to various magnitude flood events by creating or enhancing physical habitat depends upon other natural and anthropogenic factors, including physiography, bank materials, sediment supply, and availability of large wood.

- In the lower and middle McKenzie River basins, the elimination of small and large floods has contributed to a net reduction of large pools.

- High magnitude streamflows that exceed bankfull discharge (small and large floods) could be effective in the lower McKenzie River basin in creating and maintaining existing offchannel side channels, alcoves, and other secondary channel habitats.

- Gravel bars along the upper and middle McKenzie River basin reaches likely are less sensitive to discharge regime than bars in the alluvial reaches of the lower basin because steep upper basin reaches support high transport capacities and have fewer depositional settings where gravel bars historically formed.

- Spring Chinook salmon and bull trout are sensitive to the combination of discharge, stream velocity, and stream temperature. Water temperatures below seasonal norms and reduced streamflow in the spring and summer can potentially reduce the growth of fish rearing and affect the timing of smolt outmigrations and adult upstream returns. Warmer and higher streamflow in the fall affect spawning adults and can cause earlier egg hatching and fry emergence leading to reduced survival.

- Channel and floodplain simplification and the decrease in overbank streamflow events are factors in the decline of Oregon chub and Pacific lamprey, which inhabit low-velocity backwaters and isolated floodplain habitats.

- Oregon chub, western pond turtle, and red-legged frogs require diverse offchannel habitats, including side channels, sloughs, oxbow lakes, ponds, and wetlands, which are geomorphic features created and maintained by the interaction of small-large floods.
- Floodplain tree species, black cottonwood and white alder, require high winter and spring streamflow events for seed dispersion, generation of bare sunlit soil patches for germination, and adequate water tables for growth and survival.

In their seminal paper "The natural flow regime," Poff and others (1997) describe streamflow as the "master variable" because of its strong influence on many critical physicochemical characteristics of rivers, including water temperature, geomorphology, and inchannel and offchannel habitat diversity. These physicochemical responses to streamflow quantity and timing mediate all aspects of aquatic and riparian ecology. Streamflow also directly affects species ecology through, for example, its effect on bedload movement and scour, stream velocity, and change in volume of aquatic habitats. The key streamflow, geomorphology/habitat, and ecology linkages for the McKenzie River basin (as outlined in previous research and literature reviews) are presented below.

\section{Flow and Physical Habitat}

Although it is difficult to prescribe precise relations between streamflow and physical habitat because of wide variations in channel morphology, local hydraulics, sediment characteristics and other factors, the literature provides a general understanding of how different magnitude streamflow events affect channel morphology, which in turn influences the availability and complexity of physical habitat. The discharge needed to create and maintain various aspects of physical habitat has been described in various ways by previous authors. For example, "effective discharge" (the flow, or range of flows, that transport the most sediment over the long term; Wolman and Miller, 1960) is often considered to be the channel-forming discharge. Effective discharge is typically considered equivalent to bankfull streamflow, although subsequent authors have shown that effective discharge may actually be greater than bankfull streamflow for gravel bed rivers (Emmett and Wolman, 2001). Other studies illustrate the importance of floods as catalyzing channel change (Grant and others, 1984). Channel complexity is not only a function of the magnitude of individual floods, but their timing and sequence (Wolman and Gerson, 1978; Tal and others, 2004; Wallick and others, 2007). On regulated rivers for which flood flows have been reduced, Kondolf and Wilcock (1996) describe ways in which to link specific sediment or channel maintenance objectives with reservoir releases designed to mimic natural floods (termed "flushing flows"). Stakeholders developing environmental flow guidelines for the McKenzie River basin can consider the magnitude of individual streamflow events when setting objectives for physical habitat and their sequence and timing. 


\section{Pool Habitat}

It is difficult to differentiate the individual effects of different magnitude flows on pool characteristics along the McKenzie River because there are few studies to draw from, and the two most comprehensive studies of pool habitat (Minear, 1994; Sedell and others, 1991) each span one relatively long time period that encompassed a wide range of flood events as well as other natural and anthropogenic effects. Although more work is needed to better evaluate the role of different magnitude flow events on pool size, depth, and cover, findings from other river systems can be used to develop general hypotheses for the McKenzie River basin.

Pool scour and maintenance occurs under conditions of velocity reversal, in which the riffle gradient decreases (resulting in lower stream velocity) while velocity increases in the pool, leading to pool deepening (Keller 1971, Emmett and others, 1985; O’Connor and others, 1986; Thompson and others, 1999). In general, studies indicate that such conditions occur when discharge exceeds bankfull discharge; however, the magnitude of discharge required for pool scour along the McKenzie River is unknown and could be high. Wesche (1991) report that for mountain streams in Wyoming, scour did not occur until streamflows were 12 times the magnitude of bankfull discharge. Aggradation of pools by fine sediments might occur either on the receding limb of high streamflow events (Bowman, 1977) or during low streamflows (Jackson and Beshta, 1982). In addition, pool complexity is derived from a variety of other factors such as large wood, which requires higher streamflows (perhaps on the order of bankfull or greater) for recruitment and mobilization.

Along the McKenzie River study area, high streamflow events (such as small and large floods) that exceed bankfull probably have the greatest effect on pool complexity and availability (table 21). In the upper McKenzie River basin, there has been little change in the overall magnitude and frequency of peak streamflows (table 12), but for individual years (such as 1995), streamflow reduction by the hydropower dams could result in the elimination of one or more pool-scouring events (fig. 29). In the middle McKenzie River basin, small floods essentially have been eliminated (table 15), and peak discharge in a typical year is only two-thirds of bankfull (fig. 29). This substantial reduction in flow events ranging in magnitude from bankfull discharge to small-floods potentially has resulted in a net loss of pool-maintenance events, and partly could explain the reduction in large pools observed by Minear (1994). However, Minear's study spanned the period 1937-1991 and did not include the 1996 flood; hence, the reduction in pool frequency possibly may have been less dramatic had the study included this small flood.
In the lower McKenzie River basin, the frequency of small floods decreased by 76 percent, so that now these poolscouring events occur approximately once every 9 years, whereas they occurred every 2-3 years prior to 1962 (table 15). Large floods enhance pool complexity through pool scour and the creation of channel-spanning blockages of wood and sediment, which can lead to the development of new pools; however, these infrequent, regional flood events (most recently in January 1943, December 1964, and February 1996) occur on a decadal scale.

\section{Offchannel Habitat}

Possible changes in the flow regime likely have the greatest effect on offchannel habitat in the lower McKenzie River basin, which historically supported numerous side channels, alcoves, and other secondary channel features. Although determining the exact role of different magnitude streamflows on the creation and maintenance of offchannel habitats requires additional analysis using field observations, historical analysis, and numerical modeling, generalizations can be made based on previous studies. High streamflow pulses (discharge up to bankfull) can enhance offchannel habitat by inundating low-lying features, scouring fine sediments, and disrupting young vegetation. However, larger magnitude streamflows that exceed bankfull discharge (small and large floods) are also needed to carve new features and maintain existing offchannel habitats (table 21; fig. 30). Modeling results and field observations from the nearby upper Willamette River demonstrate that small floods, such as that in February 1996, are able to inundate the floodplain, trigger bank erosion, and carve new channels within erodible, lowlying areas of the active channel, but do not have sufficient power to trigger large-scale avulsions or carve side channels through high floodplain surfaces (Wallick and others, 2007). Dam building and the resultant reductions of peak flows has caused historically frequent small flood events to become relatively rare, with recurrence intervals of almost 50 years for the middle McKenzie River basin and 9 years for the lower McKenzie River basin (table 15; fig. 31). Bankfull streamflows, which are commonly referred to as the "channel forming discharge," historically occurred on a biannual basis. They have occurred only five times in the period 1962-2008 (fig. 31). Because small floods, large floods, and bankfull events each exert a unique influence on the creation and maintenance of offchannel habitat, reduced frequency of these events has contributed to a reduction in the complexity and availability of side channels, alcoves, and other secondary channel features. 


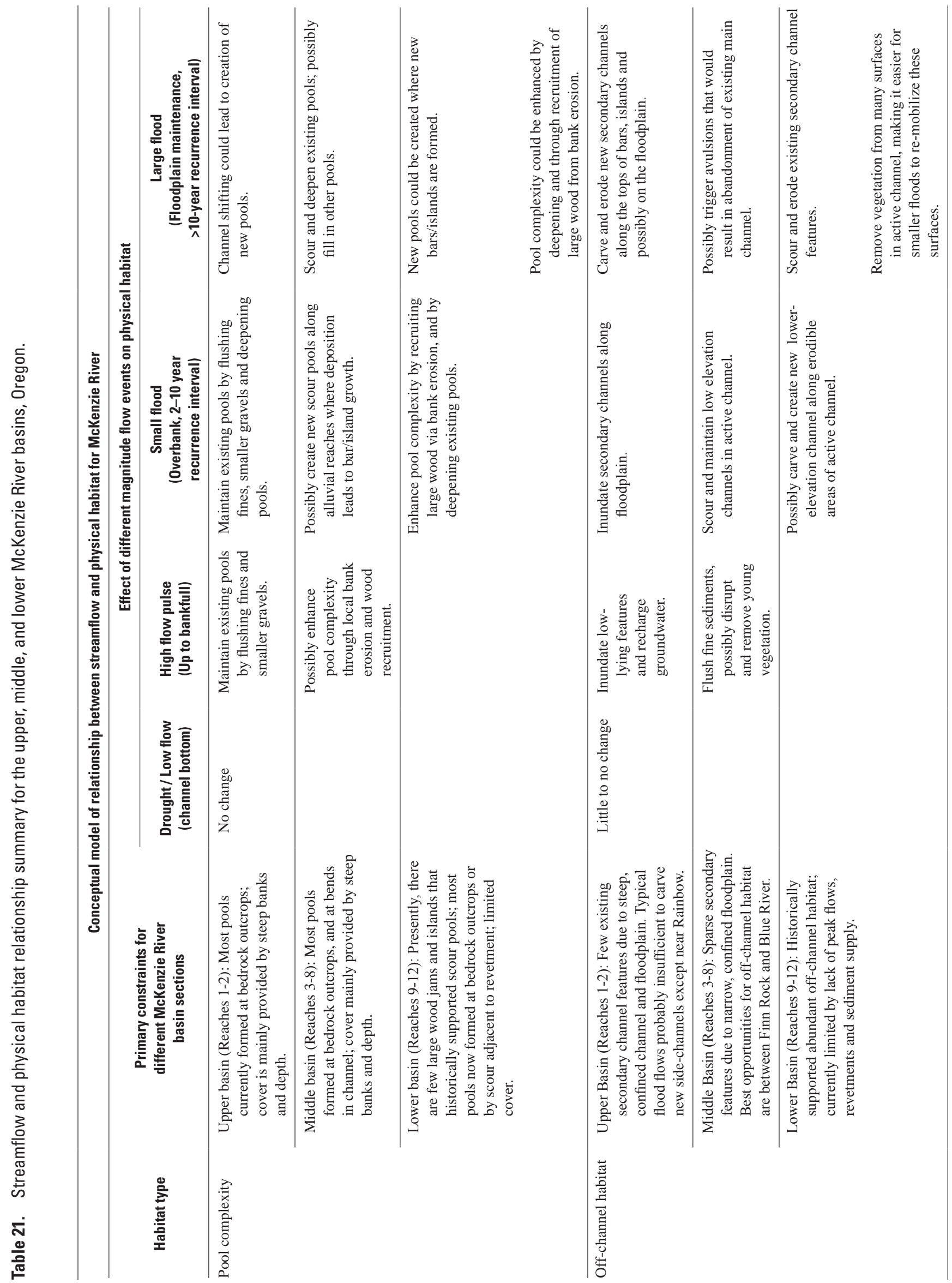




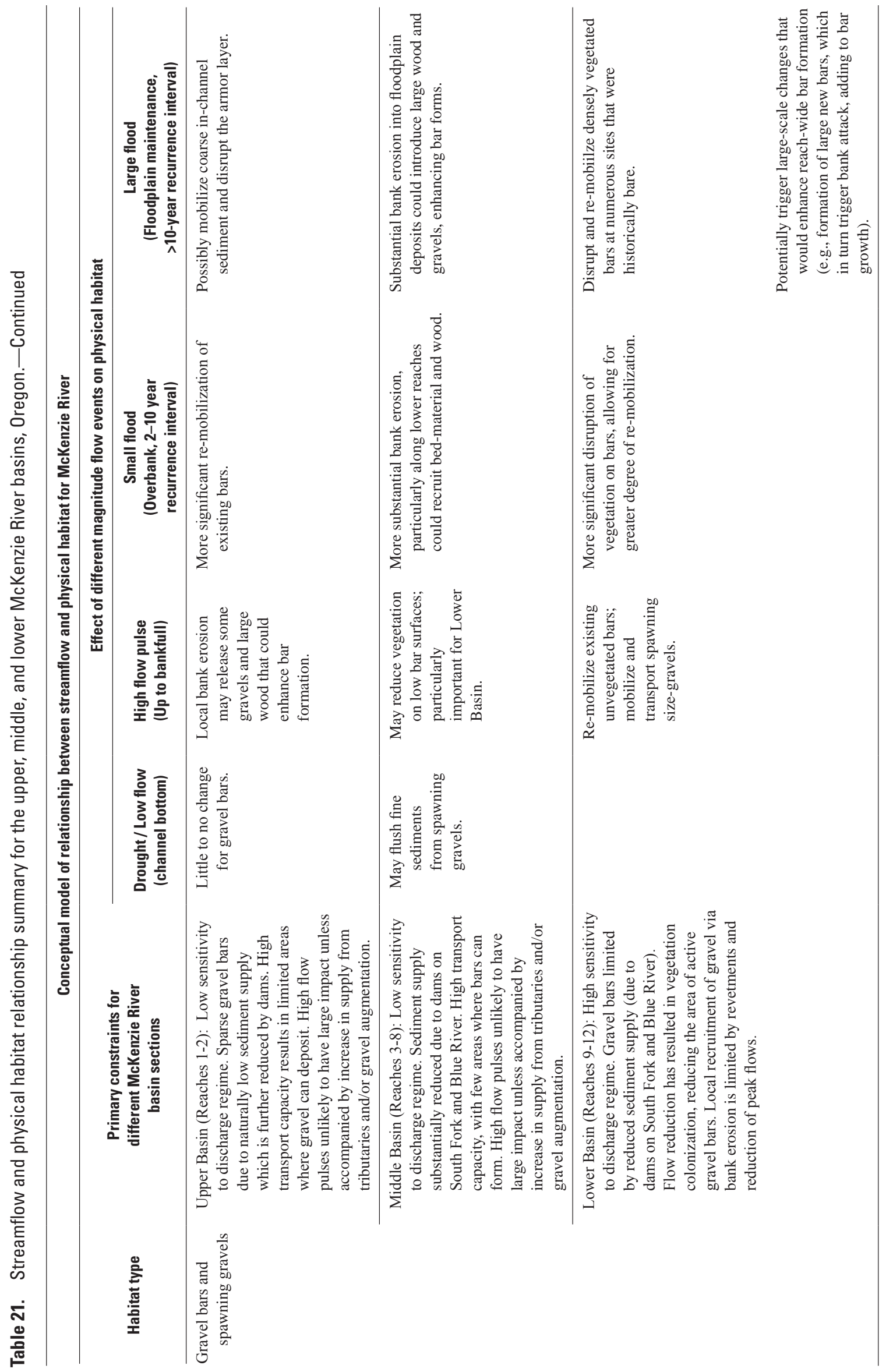




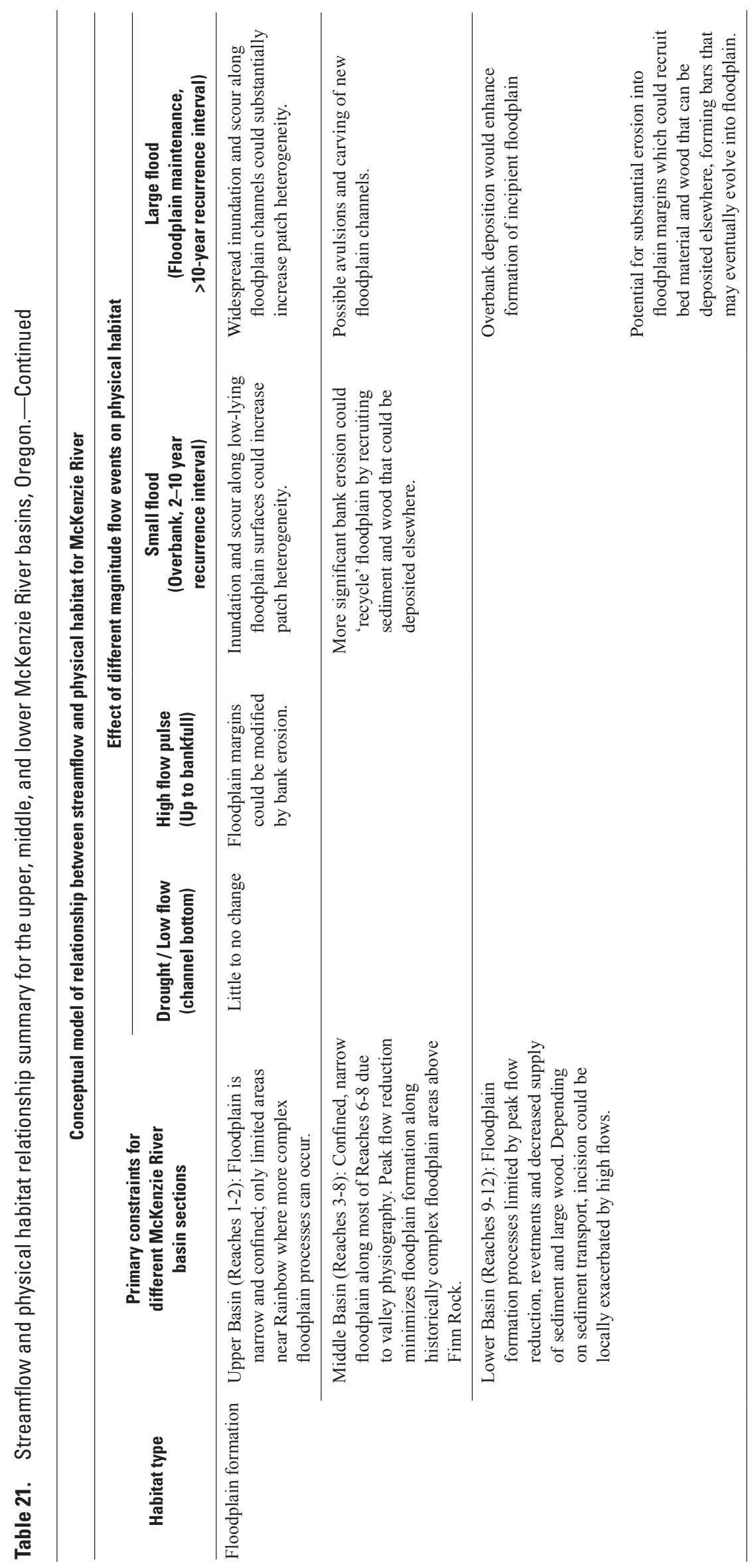




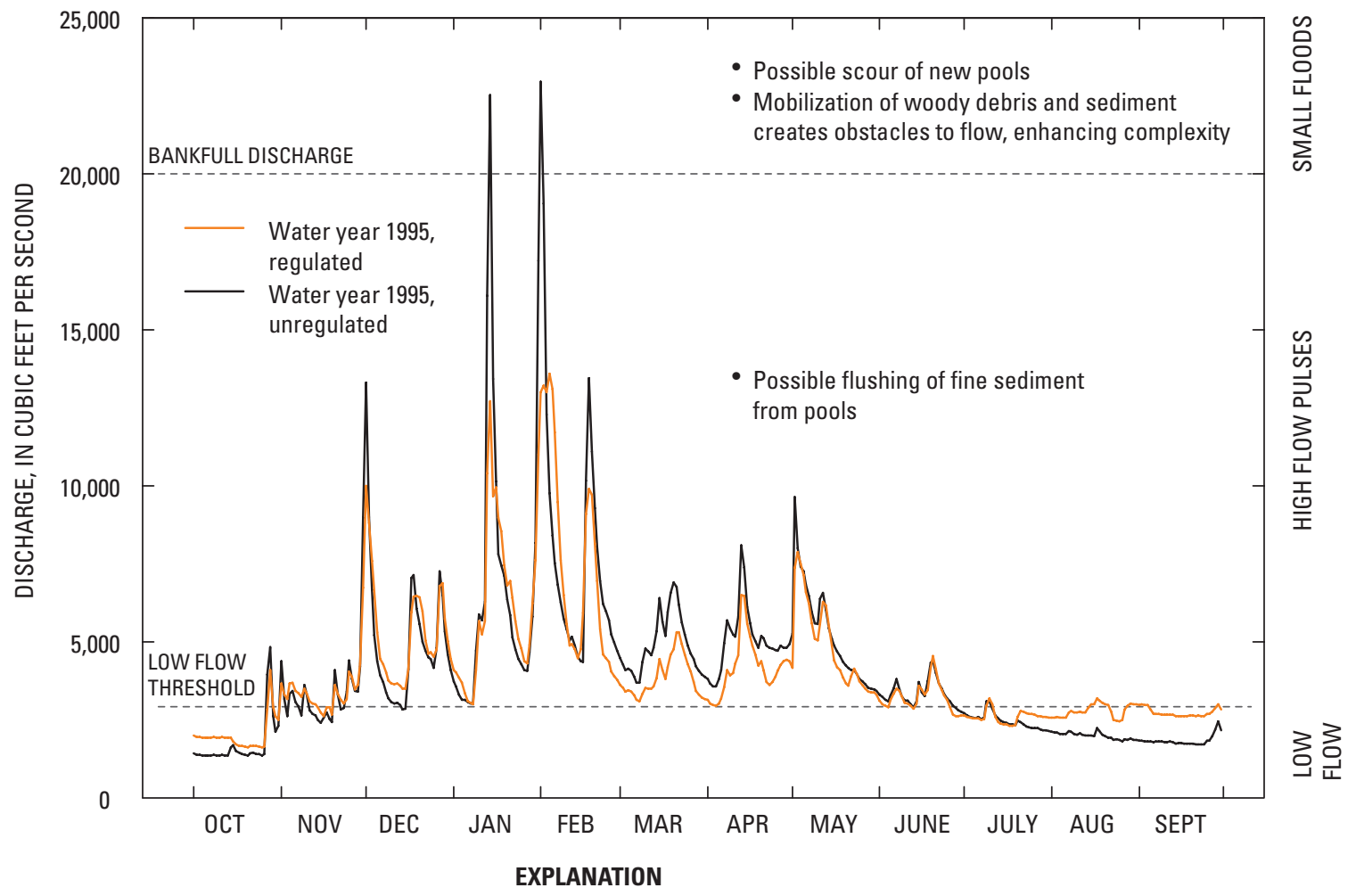

Bankfull discharge is 20,000 cubic feet per second for this stream site as shown in table 5 . Low-flow threshold, 3,030 cubic feet per second for this stream site, was computed using the indicators of Hydrologic Alteration software.

Figure 29. Pool processes in relation to observed regulated and computed unregulated daily mean streamflow at the McKenzie River near Vida, Oregon (14162500), water year 1995. 
The ability of environmental streamflows to restore offchannel habitat depends on more than flood magnitude; other factors including bank stabilization, geological controls, and incision may limit the ability of environmental flows to carve and maintain secondary channel features. Many areas along the lower McKenzie River that historically displayed abundant side channels were flanked by erodible Holocene alluvium, but are presently stabilized with revetments, which reduce lateral migration and chute formation, hence contributing to simplification of the channel network and minimizing opportunities for the creation of secondary channel features (fig. 27). A logical follow-up study might entail detailed analysis of aerial photographs taken before and after the February 7, 1996, flood, in order to determine the role of streamflow, revetments, and other influences on secondary channel formation.

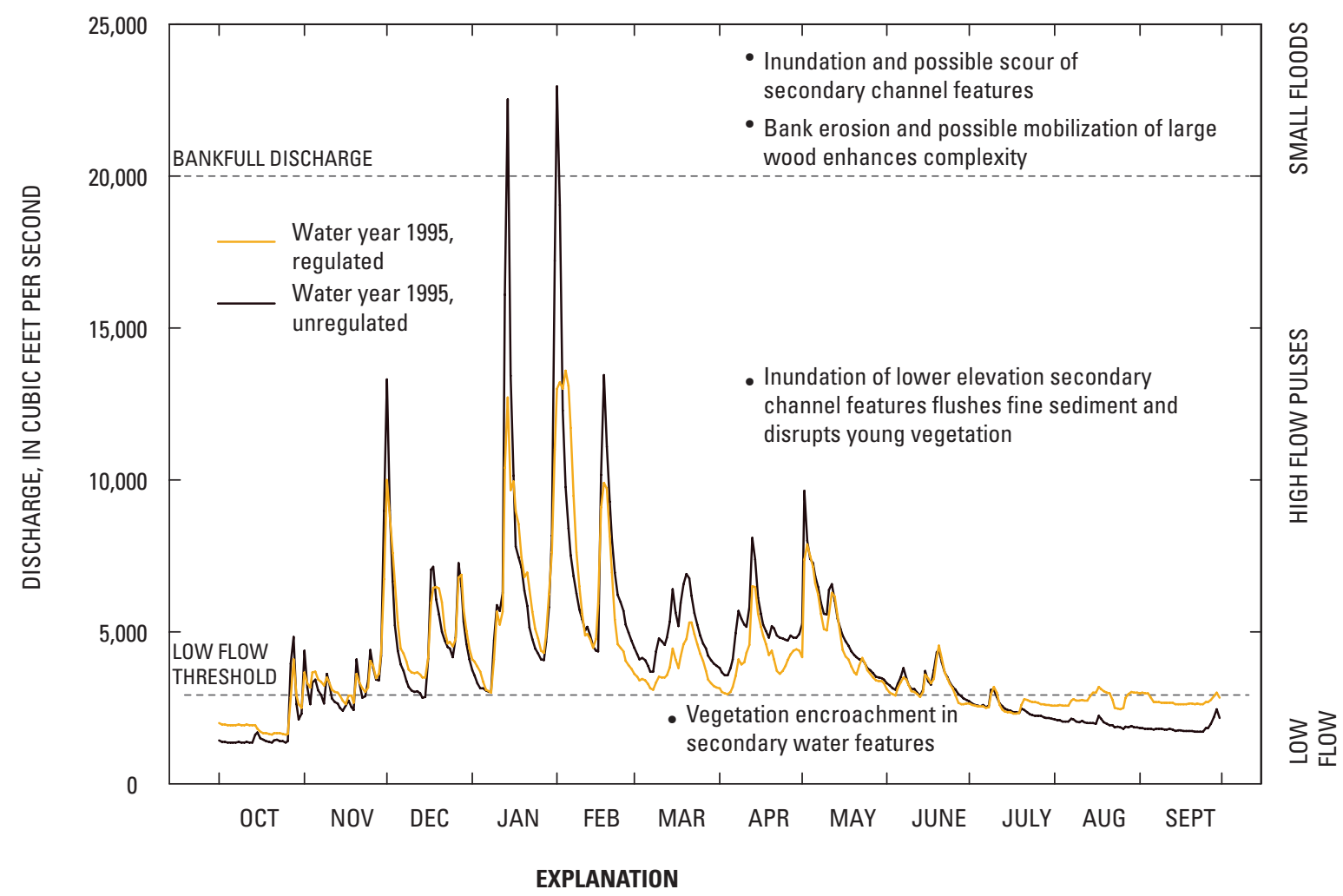

Bankfull discharge is 20,000 cubic feet per second for this stream site as shown in table 5 .

Low-flow threshold, 3,030 cubic feet per second for this stream site, was computed using the indicators of Hydrologic Alteration software.

Figure 30. Offchannel processes in relation to observed regulated and computed unregulated daily mean streamflow at the McKenzie River near Vida, Oregon (14162500), water year 1995. 


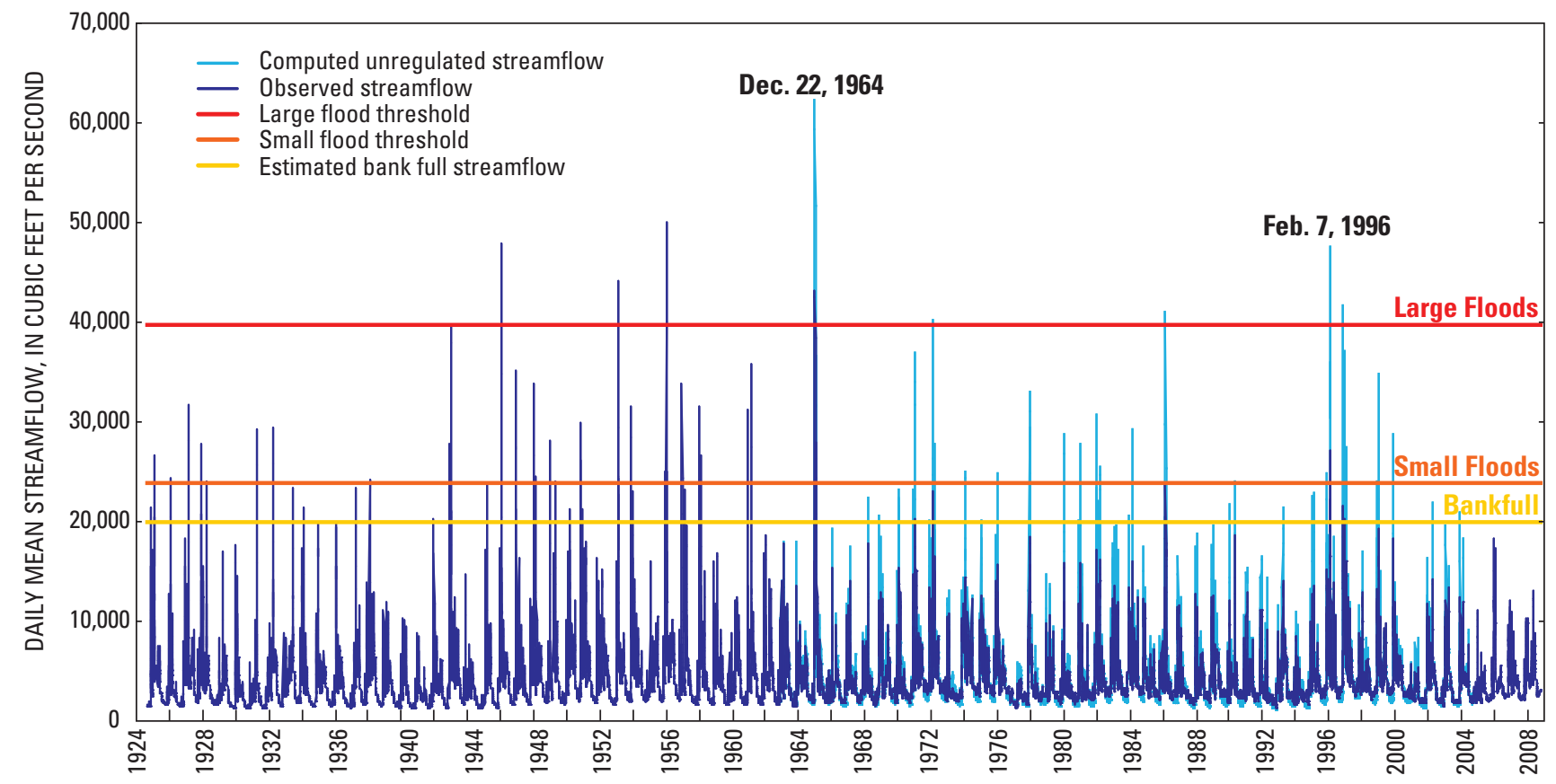

Figure 31. Observed and computed unregulated daily mean streamflow in Reach 7 at McKenzie River near Vida, Oregon (14162500), water years 1925-2008.

\section{Depositional Features}

The abundance of gravel bars, and in particular the "loose," recently deposited, unvegetated bars depends on the supply of gravels from upstream sources, the sediment transport capacity of the channel, and the frequency of flow events that can transport gravel (table 21; fig. 32). Gravel bars along the upper and middle McKenzie River basin reaches are probably less sensitive to streamflow than those in lower-basin alluvial reaches because the steep upper reaches support high transport capacities, and there are few depositional settings where gravel bars have historically formed. As a result, the channel bed along much of the upper and middle McKenzie River basin most likely is armored and unlikely to be mobilized except during extreme events. Additionally, the active channel is relatively confined within a floodplain composed of coarse Pleistocene gravels that are too large to be transported by most modern flow events (Stillwater Sciences, 2006b); hence, bank erosion along these reaches is unlikely to recruit an ample supply of transportable gravels.

The large, mobile, sparsely vegetated gravel bars that are located predominantly in the lower McKenzie River basin most likely respond dynamically to discharge regime through variation in size, frequency, and character and form the basis of streamflow-geomorphology relations shown in table 21 and figure 32. Moreover, the channel along the lower McKenzie basin is situated within a wide floodplain composed of sediments deposited during the Holocene. Thus, bank erosion along unrevetted parts of the lower McKenzie River may provide a source of gravels that could be redeposited in bars and other depositional features. 


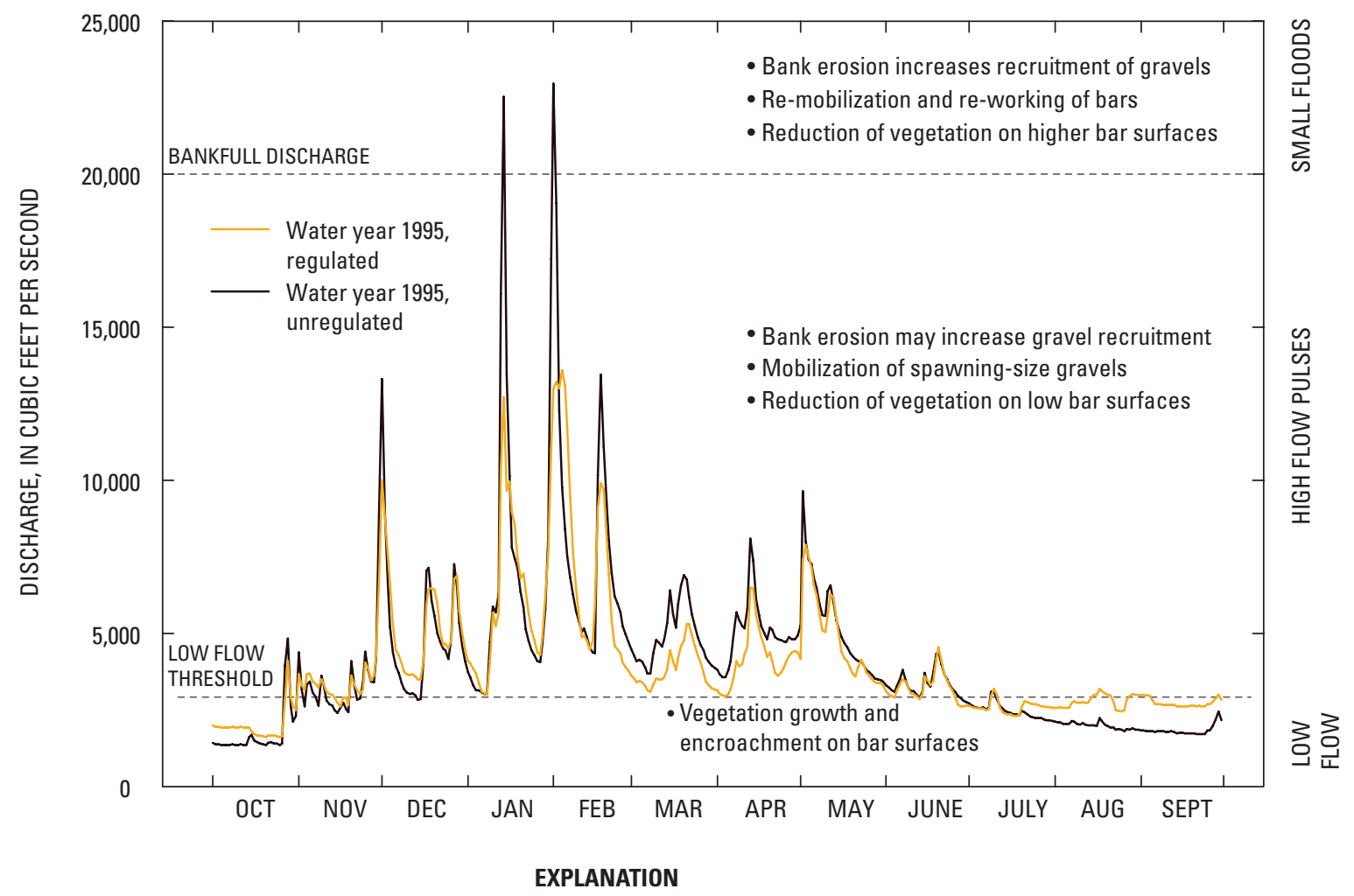

Bankfull discharge is 20,000 cubic feet per second for this stream site as shown in table 5 .

Low-flow threshold, 3,030 cubic feet per second for this stream site, was computed using the indicators of Hydrologic Alteration software.

Figure 32. Depositional processes in relation to observed regulated and computed unregulated daily mean streamflow at the McKenzie River near Vida, Oregon, (14162500), water year 1995.

Sediment supply is a key factor that not only exerts a first order control on bar frequency, but also remains unquantified for much of the McKenzie River basin, despite concerns that trapping by the dams has substantially reduced bed-material availability. In the absence of a formal sediment budget for the McKenzie River basin, the flood control dams on the historically flood and sediment-rich tributaries and sediment-rich tributaries of Blue River and South Fork McKenzie River are assumed to have led to substantial reduction in coarse bed material entering the middle and lower reaches of the mainstem McKenzie River. Additionally, streamflow reduction has contributed to vegetation encroachment and stabilization of bar features, which has reduced the area of bare, easily eroded gravel bars, contributing to the overall reduction in sediment supply (fig. 28). Therefore, the ability of different magnitude streamflow events to recruit bed material stored in bank, bar, and floodplain deposits offers a potential opportunity to partially offset reductions in sediment supply caused by the dams.
High streamflow pulses are capable of reducing vegetation on low bar surfaces, remobilizing unvegetated bars, and transporting spawning size gravels. However, large magnitude flood flows are needed to rework bars that have widespread vegetation encroachment, such as those shown in the 2005 aerial photographs (fig. 28). These formerly active bars appear to be unaffected by high streamflow pulses during the post-dam period (fig. 31). Small floods likely would trigger greater remobilization of existing bars by reducing or eliminating vegetation on many bar surfaces. Although small floods, such as the February 1996 event, have occurred infrequently since dam construction, (table 15; fig. 31) these events are likely to promote bank erosion, particularly along unrevetted areas of the lower McKenzie River basin where gravels and wood released from bank erosion could enhance bar formation. Large floods (such as the one in December 1964) can rework and remobilize even densely vegetated bars and potentially trigger large-scale channel changes such as avulsions and rapid meander migration. This in turn can recruit large wood and sediment, which contributes to the size, frequency, and diversity of bar features. 


\section{Flow and Exemplar Species}

The nine exemplar aquatic and terrestrial species in the McKenize River basin selected for the report include five native fish species (spring Chinook salmon, bull trout, Pacific and brook lamprey, Oregon chub), red-legged frog, western pond turtle, black cottonwood, and white alder. Gregory and others (2007a) summarized the life history and streamflow relationships of the species (with the exception of bull trout) for the Coast Fork and Middle Fork Willamette Rivers. Excerpts from that document are presented below in italics, in total or with slight modification. These exemplar species predominantly are found in a combination of mainand offchannel habitats, and offchannel or riparian/floodplain habitats singularly.

\section{Aquatic Main Channel}

In their Coast and Middle Fork Willamette analysis, Gregory and others (2007a) summarized key life history and environmental flow requirements for main- and offchannel fish species, which are also applicable to the McKenzie River basin:

- Fall flood pulses are important for passage of adult salmon.

- Magnitude, timing, and duration of spring streamflows are important cues for upstream migration of adult salmon and downstream migration of salmon smolts.

- Bankfull and overbank streamflows are important for Oregon chub, which inhabit backwaters and isolated floodplain habitats.

- For salmon and steelhead, adequate "incubation streamflows" must be maintained over redds created during spawning.

- Influences of streamflow modifications and thermal regime due to dam operation differ between spring-and fall-spawning native fish species.

- Spring-spawning species include coastal cutthroat trout, lamprey, and all native cyprinids (minnows), suckers, and sculpins.

- Fall-spawning species include spring Chinook salmon and bull trout.

- Non-native species (such as bass, catfish, mosquitofish, carp) typically are spring and early summer spawners.

- Flow modification in any season potentially affects the growth and survival of juvenile fish.

- Flow modifications in spring influence both adults and fry of spring spawning species.

- Flow modifications in autumn influence both adults and fry of fall spawning species.
- In the mainstem Willamette River and major tributaries, native fish may be migrating during any month of the year.

- Dam operations have been linked directly and indirectly to declines in spring Chinook salmon.

- Channel and floodplain simplification have been identified as major factors leading to the declines in Oregon chub, Pacific lamprey, and possibly coastal cutthroat trout.

- Creation of warmer, more lacustrine habitats in the Willamette River favor invasion by bass, carp, catfish, and other nonnative species.

Two recent reviews have compiled extensive information available related to the upper Willamette River spring Chinook salmon (Oncorhynchus tshawytscha) and the contribution of dam operations (U.S. Army Corps of Engineers, 2000) and other anthropogenic factors to its decline (Northwest Power and Conservation Council, 2004). In addition, the NMFS Technical Recovery Team has recently provided an in depth analysis of historical population structures and distributions for spring Chinook salmon (Myers and others, 2006).

From Gregory and others (2007a):

Spring Chinook enter the Columbia River and lower Willamette River in February through April. They move over Willamette Falls by fish ladder in April through June after river temperatures exceed $10^{\circ} \mathrm{C}$. Spawning in the upper Willamette River occurs from September through October [fig. 33, in this report]. Some juvenile salmon migrate downstream as fry or fingerlings, but they are not physiologically capable of tolerating the higher salinities of the estuary until late summer of their first year. ....Most spring Chinook from the upper Willamette River enter the ocean as yearlings and return to the Willamette River as 4- to 6-year-old adult fish.

Flow modifications have several potential effects on upper Willamette River spring Chinook. Like most salmonids, Chinook salmon are particularly sensitive to the intertwined parameters of discharge, stream velocity, and stream temperature. The factors are major cues for salmonid life histories, and alteration of the timing of streamflow or stream temperature can alter the growth and survival of all riverine life history stages. Unnaturally cooler water in the spring/summer (along with lower streamflows in spring) can potentially reduce the growth of fish rearing in the river and affect the timing of smolt outmigrations and adult upstream returns. Likewise, warmer temperatures in the fall can affect spawning adults or cause earlier egg hatching and fry emergence from the gravel nests through accelerated development, thereby exposing them to high winter streamflows [table 18 and fig. 33, in this report]. 

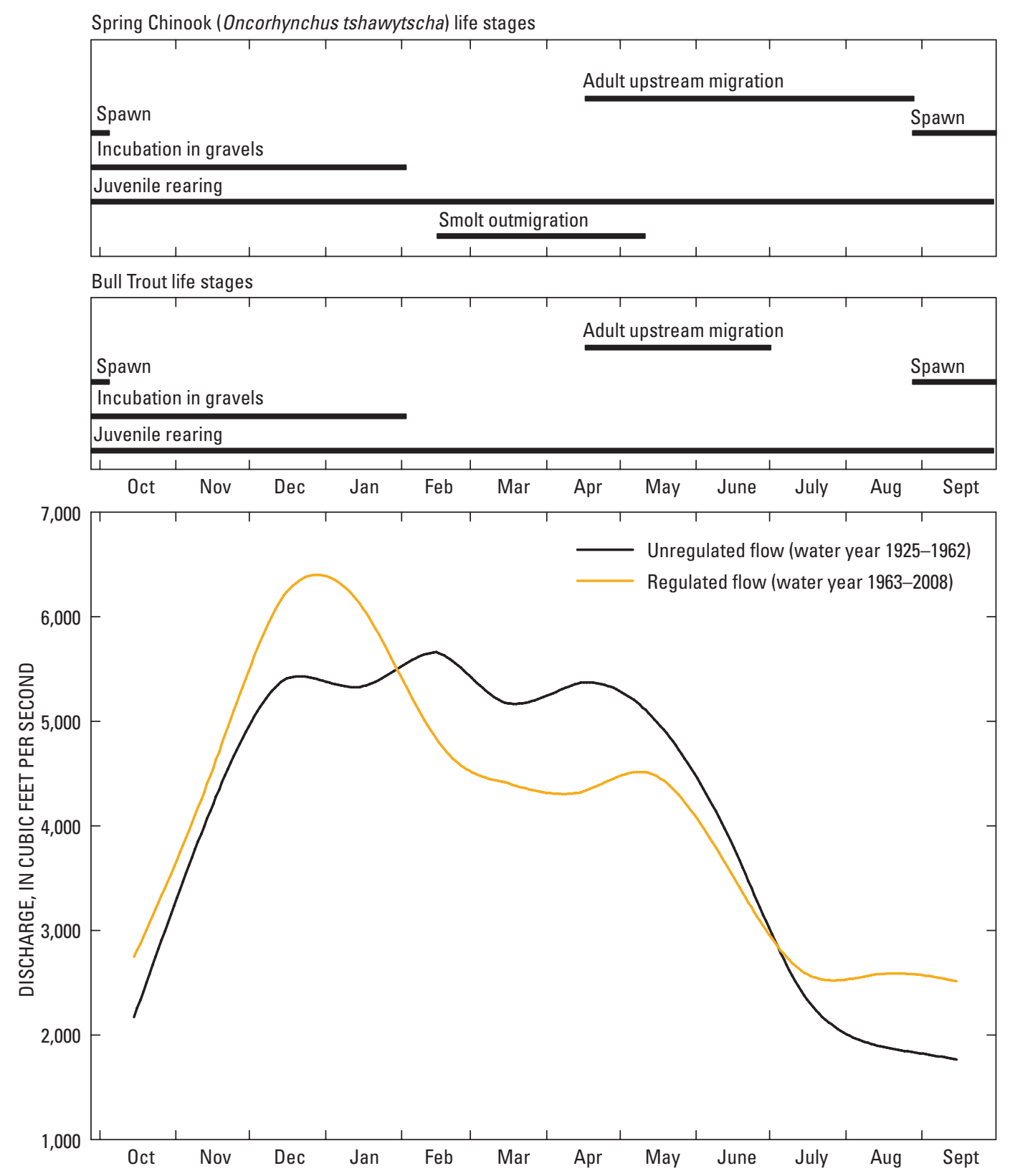

Figure 33. Life history of two native aquatic species, one anadromous (Chinook salmon) and one resident (bull trout), in relation to pre- and post-dam mean monthly streamflow at McKenzie River near Vida, Oregon (14162500).

As discussed earlier, releases from the Cougar and Blue River Dams for many years have been unnaturally cooler and warmer in the spring/summer and fall, respectively (figs. 21 and 22). Although the temperature of streamflow releases from Cougar Dam now mimic a more natural pattern, similar infrastructure modifications to Blue River Dam have not been made. However, the downstream thermal effect of Blue River is limited since the streamflow of Blue River is only approximately 10 percent of the streamflow at the McKenzie River near Vida (14162500) streamflow-gaging station. 
From Gregory and others (2007a):

An increasing body of evidence from other large river systems suggests floodplain habitats are important low stream velocity refuges and nursery areas for young Chinook. Loss of these areas combined with bank simplification through revetments resulted in deleterious consequences for other salmonid populations. Recent work in the upper Willamette River mainstem has found winter use of floodplains, alcoves, and ephemeral streams by numerous native species, including spring Chinook. During winter streamflows, these areas apparently provide refuge both from high streamflows and introduced predators, as well as food from terrestrial and aquatic sources.

Dam and reservoir operations have also been implicated in fungal and parasitic infections. Smolts that experience high streamflows during outmigration tend to have lower overall rates of infection. Higher streamflows may decrease abundance of intermediate hosts for infections such as whirling disease (Myxobolus cerebralis) and Ceratomyxa shasta.

Bull trout are a nonanadromous salmonid that are coldwater species primarily found in large mountainous upper river basins and their tributaries (Taylor, 2003). They have largely been extirpated from all Western Cascade river basins except for the McKenzie River. Although they can seasonally migrate long distances and probably regularly move down to the mouth of the McKenzie River, they primarily occupy habitats in the tributaries and mainstem upstream of Belknap Hot Springs (RM 118 of the mainstem). Spawning primarily occurs in two subbasins: upper basin tributaries just below Trail Bridge Dam (Anderson and Olallie Creeks) and the South Fork McKenzie River above Cougar Reservoir (Roaring River) (Taylor, 2003). Bull trout have a similar life history pattern to spring Chinook salmon and other salmonids; spawning occurs from September to October in well-sorted gravels/cobbles located in the tail end of pools and riffles (fig. 33). Snorkeling surveys described by Taylor (2003) showed that juveniles primarily use low-velocity areas in marginal pools (backwater and lateral scour pools) with nearby cover (primarily boulders, wood, and other substrates). Juvenile rearing is generally confined to the reach between Trail Bridge Dam and Belknap Springs (Taylor, 2003).

From Gregory and others (2007a):

In contrast to the plethora of data available for spring Chinook, comparatively little is known about the life cycle and flow needs of another native anadromous species, the Pacific lamprey (Lampetra tridentata). Pacific lamprey are large, parasitic only in the marine adult stage, and historically were probably abundant in the Willamette River. The same changes to discharge, temperature, and sediment parameters that affect salmon likely also have led to the observed declines in Pacific lamprey. Adults return in late spring and spend the summer and autumn in the river before spawning as early as February (at Willamette Falls) or as late as July [ifg. 34, in this report]; some individual adults may be repeat spawners (like steelhead). Pacific lamprey require small gravels for their nests, but fine silts and clays for larval rearing, which can last up to 7 years. Young lamprey (which are filter-feeders and not parasitic) are particularly susceptible to rapid streamflow fluctuations, and can be stranded if discharges drop rapidly. Water temperatures greater than $22^{\circ} \mathrm{C}$ cause mortalities of eggs and larvae; however, additional temperature and streamflow requirements are largely unknown. Larval outmigration appears to be triggered by a combination of discharge and temperature, and usually occurs in the spring. The much smaller western brook lamprey (Lampetra richardsonii) has a markedly different life cycle from the Pacific lamprey, but has similar streamflow, temperature, and sediment requirements. Unlike the Pacific lamprey, brook lamprey are neither anadromous nor parasitic. Brook lamprey spawn in late spring as water temperatures rise to $10^{\circ} \mathrm{C}$; the eggs drift at night into silty backwater areas, where they hatch and metamorphose up to 6 months later. The filter-feeding ammocoete larvae spend the next 5 years in these areas before metamorphosing to adults, spawning, and dying. Both species require complex low-velocity areas for rearing, and loss of the low-gradient floodplain habitats (described previously) has been cited as a major cause for the observed declines in abundance of both species, particularly Pacific lamprey.

Spring Chinook, bull trout, and brook and Pacific lamprey require a diversity of instream and offchannel habitats. In addition, they are all cold-water species and spawn in similar flowing water habitats (figs. 33 and 34). As summarized in tables 21 and 22, these four species use or require habitat features that are created and maintained primarily by the interaction of small to large floods with local landscape features. Habitat features of particular importance common to these species include large deep mainstem pools, secondary channels, and well-sorted spawning gravels with interstitial streamflow. All four species also are sensitive to the seasonal timing of streamflows and water temperatures and thus are affected by alterations to streamflow and water temperature associated with dam operations. 


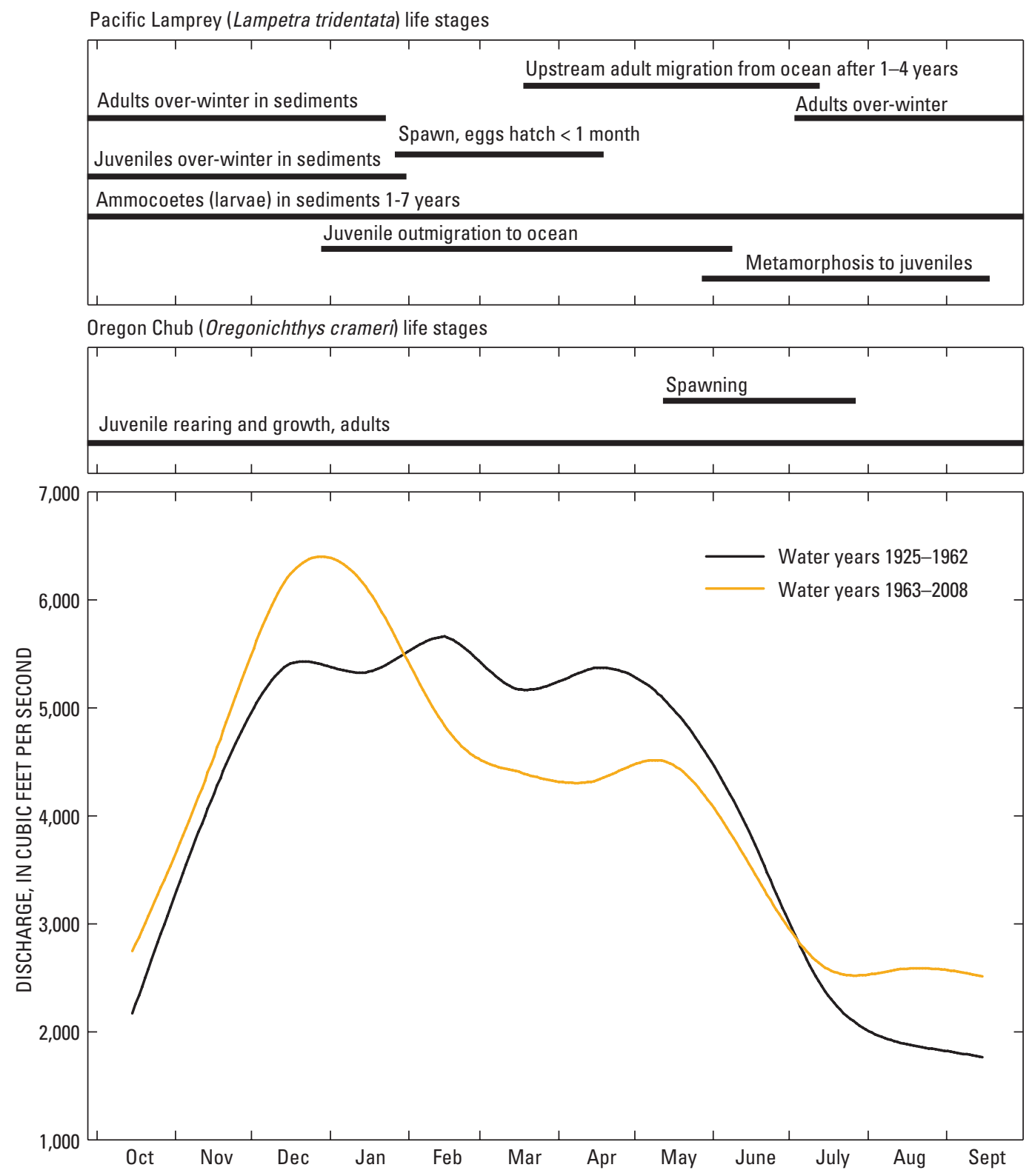

Figure 34. Life history of two resident native aquatic species, Oregon chub and Pacific lamprey, in relation to pre- and post-dam mean monthly streamflow at McKenzie River near Vida, Oregon (14162500). 


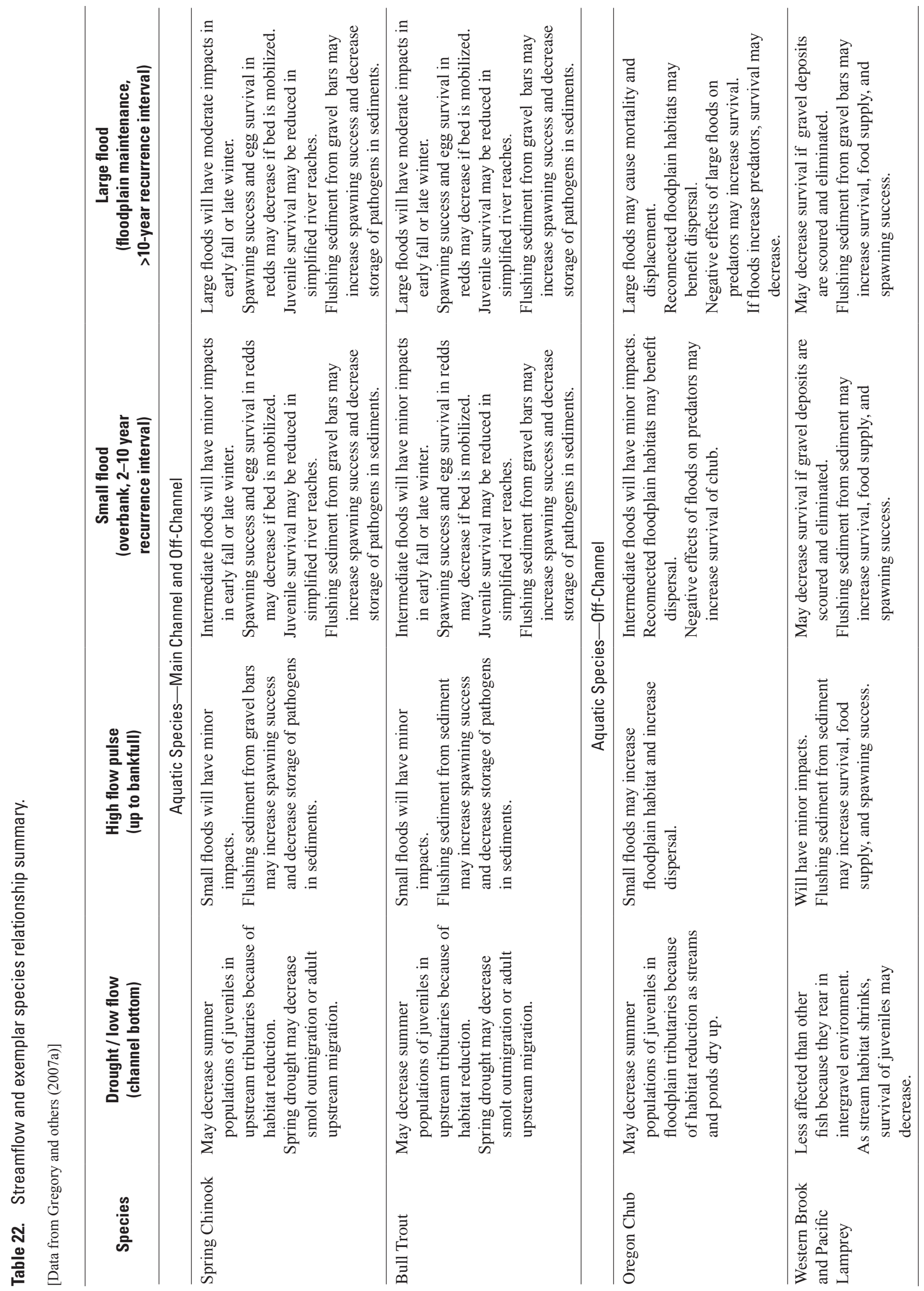




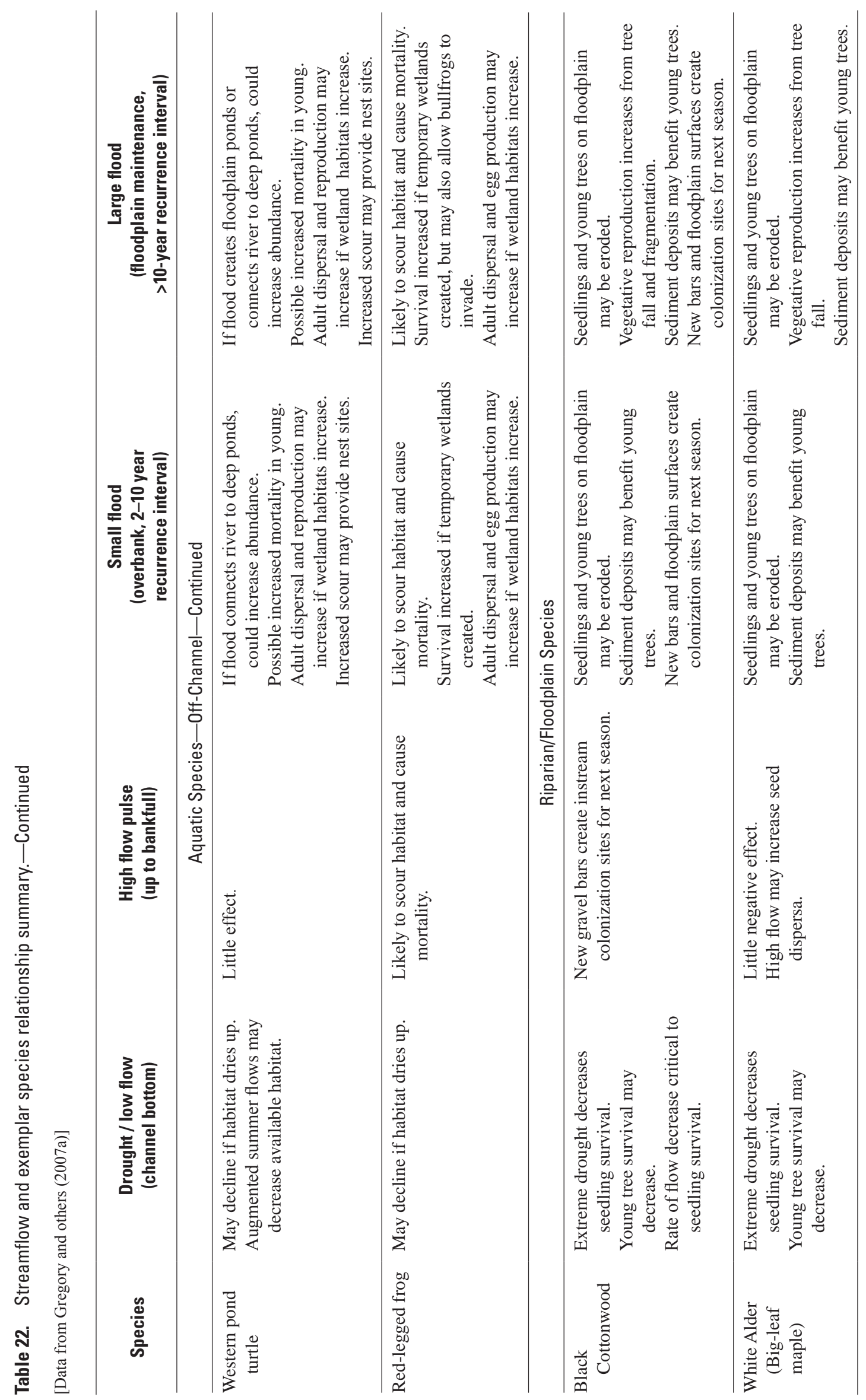




\section{Aquatic Offchannel}

Excerpted from Gregory and others (2007a):

The Oregon chub, Oregonichthys crameri, is endemic to the lowlands of the Willamette River basin and was once widely distributed, but currently is found only in a few isolated locations along the Willamette River and its larger tributaries. Oregon chub inhabit backwaters and isolated floodplain habitats, and were probably once more common inhabitants of these slackwater areas. The loss of floodplain habitats and connectivity to larger river systems is one of the main contributing factors to the decline of the Oregon chub and correlates with the construction of revetments and dams. Exact streamflow and temperature requirements for the chub are largely unknown, although chub in the Middle Fork Willamette apparently require a water temperature of at least $15^{\circ} \mathrm{C}$ to spawn. Chub are frequently found in the same locales as red-legged frogs, suggesting these two species may respond to similar temperature and discharge regimes.

Western pond turtles (Actinemys marmorata) are not limited solely to ponds, but also are found in backwaters, sloughs, marshes, and low-velocity regions of large rivers. Wooded riparian patches near open areas appear to be a predictor for adult turtles: most hibernate in forested floodplains and uplands, and the downed wood provides important basking sites. In addition to requirements for comparatively low velocity habitats, sunny, open areas with little vegetation for nesting habitat are also critical. Nests are constructed during early summer; the young hatch about 3 months later, and remain in the nest until the following spring [fig. 35, in this report].

Red-legged frog (Rana aurora) breeding sites are usually found in relatively heavily vegetated locations with significant areas flooded in winter and spring. Breeding sites in the Willamette Valley can be associated with upland ponds as well as floodplain forest wetlands. These breeding sites expand with the onset of winter rains and overbank flood streamflows, and may be dry by midsummer. Red-legged frogs breed and lay their eggs in these shallow ponds during January and February [fig. 35, in this report]; the eggs hatch within 1 to 2 months. Tadpoles spend approximately 3 months before metamorphosing to adults. Red-legged frogs occasionally breed in side channels and sloughs associated with large rivers, and generally lay eggs in areas of little or no current. As with other amphibian species, red-legged frogs may be indicators of a number of environmental insults due in part to their use of different habitats over their life history. Egg masses may be stranded by fluctuating water levels. Loss and alteration of wetlands associated with agriculture and urban areas is likely one of the most critical challenges for red-legged frogs in the Willamette Valley.

Oregon chub, western pond turtle, and red-legged frogs are native species that require diverse offchannel habitats, including mature side channels, sloughs, oxbow lakes, ponds, and wetlands. These geomorphic features are primarily created and maintained by the interaction of small to large floods with the local landscape features as described above and summarized in table 22.

\section{Floodplain Habitat and Riparian Vegetation}

From Gregory and others (2007a):

Black cottonwood, Populus trichocarpa, [fig. 36 and table 22, in this report] and riparian willows are considered pioneer species that require bare, moist mineral soils for germination. These surfaces can range from bare gravel bars generated by annual floods or large overbank streamflows that deposit bare soils on the floodplain. The seeds are viable for only 1 to 2 weeks under optimum conditions; once germinated, the rate of streamflow recession is critical. The roots lengthen and follow the decline of the water table; too swift a recession rate, and the seedlings will not survive. The seedlings are highly resistant to inundation and sediment deposition, but are shade intolerant and will not germinate under existing stands. Both cottonwood and willow can also reproduce from broken branches and root fragments; large floods can therefore transport not only seed propagules, but vegetative ones as well.

White alder, Alnus rhombifolia, [fig. 36 and table 22, in this report] is an early successional stage species that is found along perennial streams and rivers in lowland valleys. Seeds drop from the trees in late summer or early fall and are dispersed by both wind and water. White alder requires bare mineral soils for germination and can colonize many of the same habitats as cottonwood. Seedlings require continuously moist sites, and will suffer high mortalities under dry conditions. Like cottonwood, it is shade intolerant, and can regenerate from sprouts as well as seeds.

For these floodplain tree species, high winter and spring streamflows are essential for the dispersal of seed and vegetative propagules, generation and maintenance of bare soils for germination, and maintenance of proper water tables for seedling and mature tree growth and survival. These critical life history stages and their relation to preand post-dam mean monthly streamflows are presented in figure 36. 
Red-legged Frog (Rana aurora) life stages

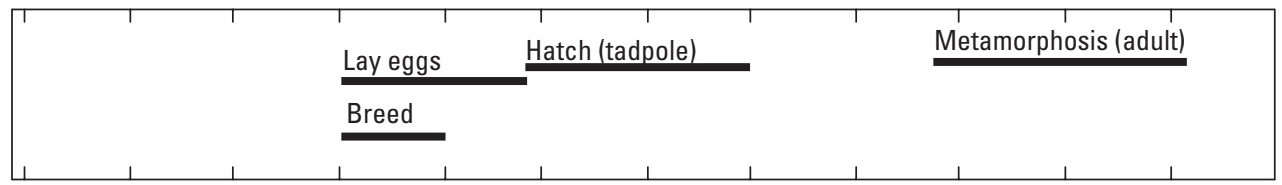

Western Pond Turtle (Actinemys marmorata) life stages

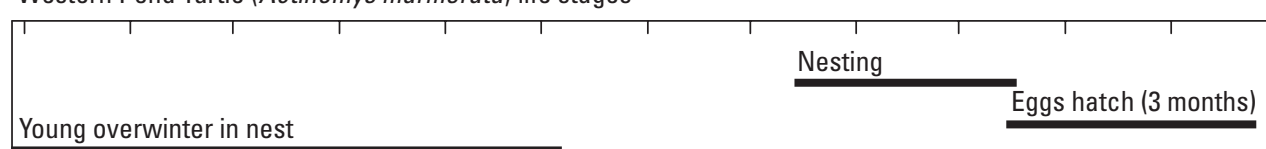

Young overwinter in nest
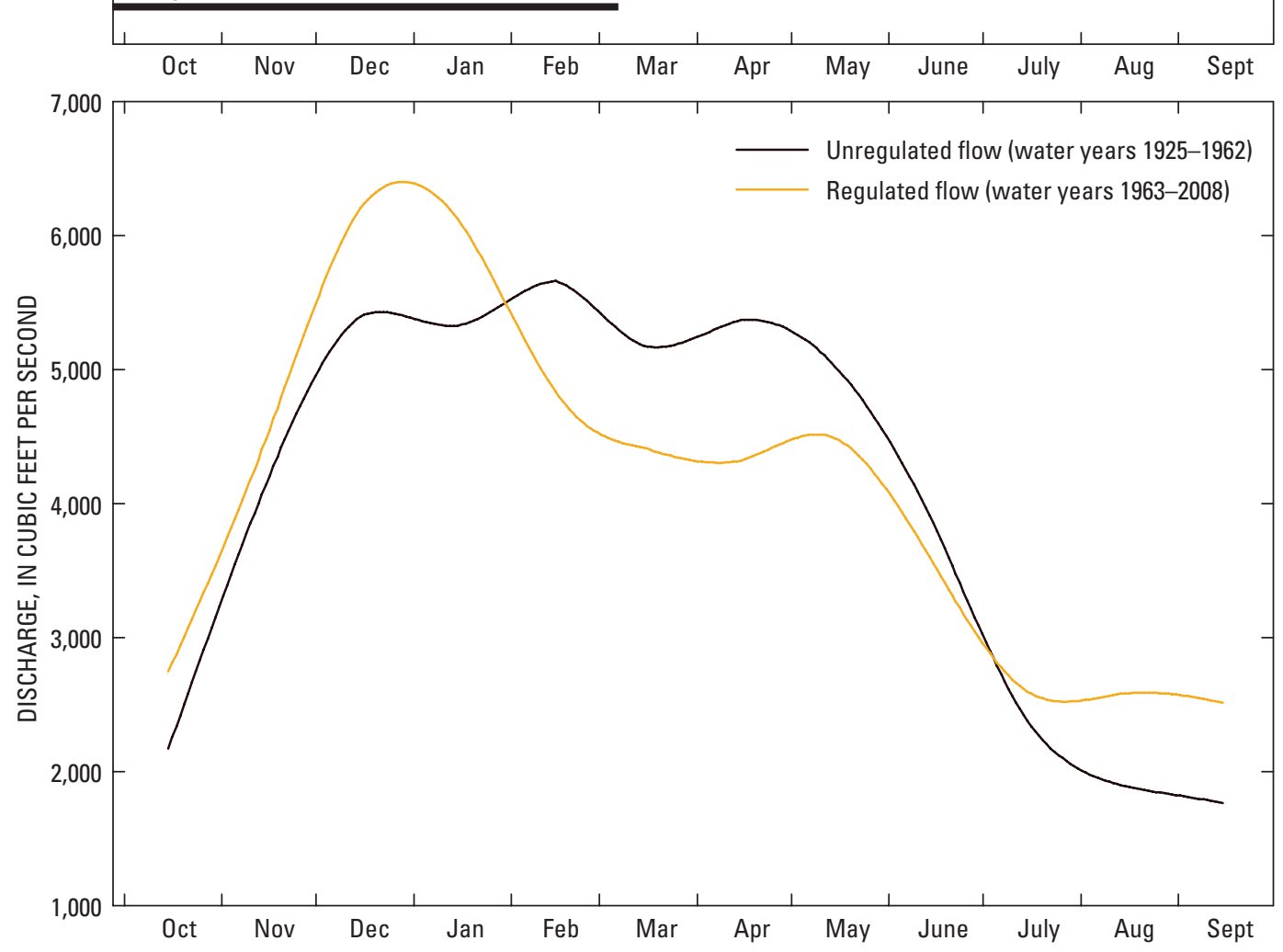

Figure 35. Life history of two resident native offchannel species, western pond turtle and redlegged frog, in relation to pre- and post-dam mean monthly streamflow at McKenzie River near Vida, Oregon (14162500). 
Black Cottonwood (Populus balsamifera ssp. trichocarpa) life stages

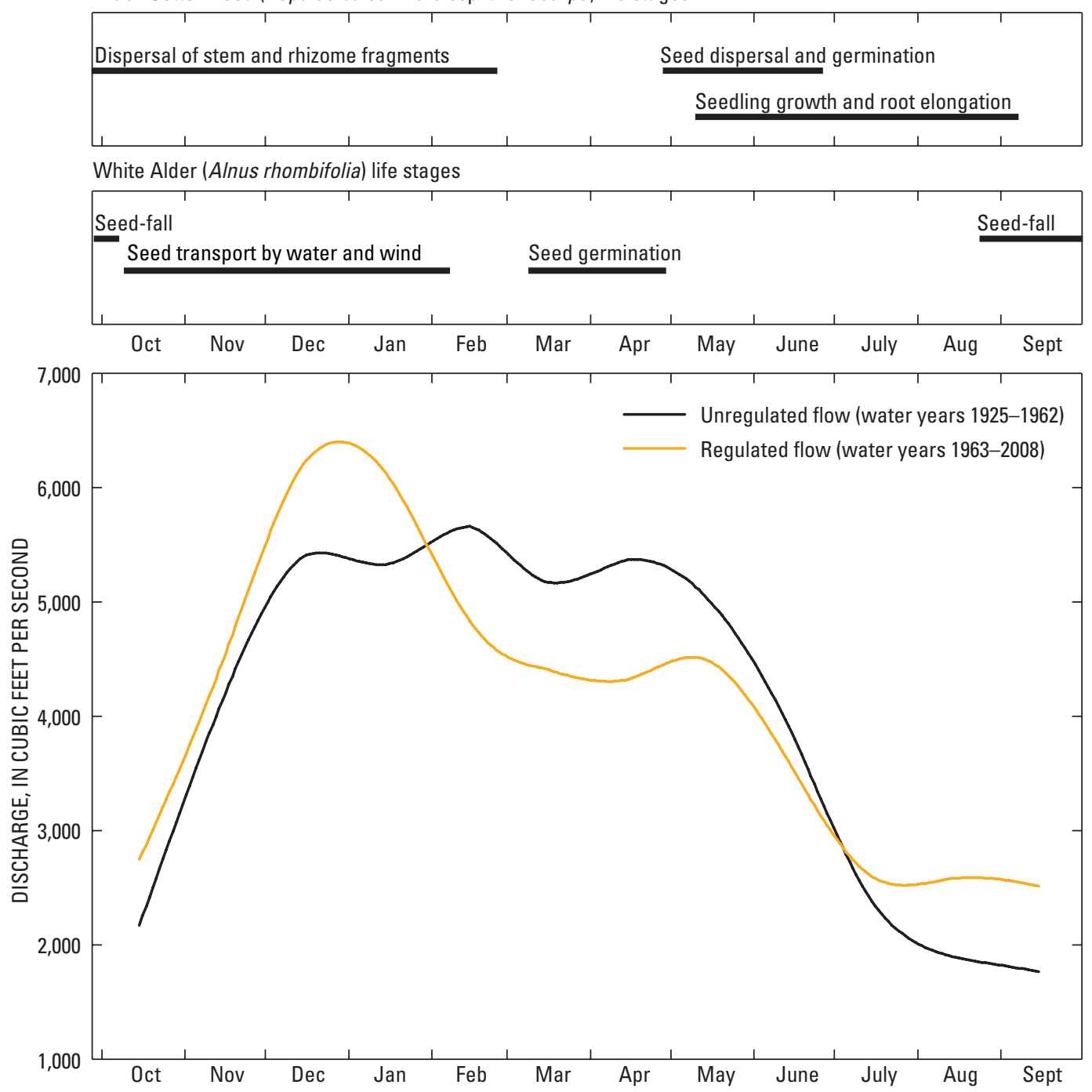

Figure 36. Life history of two native riparian vegetation species, black cottonwood and white alder, in relation to pre- and post-dam mean monthly streamflow at McKenzie River near Vida, Oregon (14162500). 


\section{Summary}

This study was a collaborative effort between the U.S. Geological Survey, The Nature Conservancy, the Eugene Water \& Electric Board (EWEB), and the U.S. Army Corps of Engineers under the auspices of the Sustainable Rivers Project. In 2002 The Nature Conservancy and U.S. Army Corps of Engineers began the Sustainable Rivers Project for the purpose of modifying dam operations and implementing environmental flow requirements for various river systems around the country. This report provides a baseline assessment of McKenzie River basin hydrology, geomorphology, and biology and their linkages. Information from the report will assist McKenzie River basin stakeholders in the development of future environmental flow requirements at an upcoming workshop. Final decisions from the workshop will be published in a second report.

The McKenzie River is approximately 90 miles long with a drainage area of approximately 1,300 square miles. Streamflows originating in the upper basin are fed by highly productive springs that were formed as a result of the young High Cascade volcanic geology. For this study the river was divided into 12 study reaches, each having unique streamflow and sediment input conditions. The McKenzie River is regulated by two flood control projects (Cougar and Blue River), an upper basin hydropower complex (Carmen-SmithTrail Bridge), and two hydropower canals (Leaburg and Walterville). The upper basin EWEB dams (Carmen, Smith, Trail Bridge) have slightly affected hydrology by decreasing annual 1-day maximum streamflows. However, the Cougar and Blue River dams have significantly reduced the magnitude and frequency of floods (on average, frequency of small floods reduced by 46 and 51 percent, respectively) while increasing the annual 7-day minimum streamflows. In the lower reaches, the McKenzie River supplies streamflow to the Leaburg and Walterville power canals. Up to $2,500 \mathrm{ft}^{3} / \mathrm{s}$ of the streamflow can be diverted into the canals so long as a minimum of $1,000 \mathrm{ft}^{3} / \mathrm{s}$ of streamflow remains in the McKenzie River.

Sufficient streamflows and cool stream temperatures are essential habitat requirements for aquatic species in the McKenzie River basin. In 2006 the Oregon Department of Environmental Quality listed a total of 112.4, 6.3, and 55.7 miles of McKenzie River basin mainstem and tributary stream reaches as thermally impaired for salmonid rearing, salmonid spawning, and bull trout habitat, respectively. Stream temperatures are affected by a variety of anthropogenic factors, such as the removal of riparian vegetation, urban and agricultural land use, geomorphic disturbance, and dam streamflow releases. Although the effect of upper basin dams on stream temperatures has been minimal, streamflow releases from the Cougar and Blue River dams have been unnaturally cooler in the summer and warmer in the fall. These changes to the thermal regime can be observed downstream on the McKenzie River at the streamflow gage near Vida, Oregon.
McKenzie River geomorphology was evaluated using reach characterization, historical channel mapping, and specific gage analysis methods. Although more detailed studies are needed to determine the precise effects of various magnitude flow events on physical habitat in different areas of the McKenzie basin, the findings from this study, in combination with earlier studies, provide a framework for assembling general relationships between streamflow and physical habitat.

In the upper (Reaches 1-2) and middle (Reaches 3-8) McKenzie River basin, most pools are formed at bedrock outcrops. In contrast these forced pools are less important in the lower McKenzie River basin (Reaches 9-12) than scour pools that typically resulted from channel-spanning blockages of wood and sediment. Pool complexity depends on multiple factors, including availability of large wood, overhanging banks, and sediment supply. Discharge events ranging in magnitude from bankfull streamflow to small floods likely could improve pool habitat throughout the middle and lower basins of the study area by deepening pools, flushing fine sediments, and potentially recruiting large wood that would enhance cover. Large floods could, in addition to improving pool habitat, potentially create new pools, especially in the lower McKenzie River basin where channel shifting and island growth can facilitate pool formation.

Offchannel habitat historically was most abundant along the lower, alluvial reaches of the McKenzie River basin, whereas the steeper, more confined reaches along the middle and upper McKenzie River basins presented few opportunities for secondary channel features. Therefore, discharge events that exceed bankfull streamflow are likely to have the greatest effect on secondary channel features in the lower McKenzie River basin by enhancing side channels, alcoves, and sloughs. Small floods may scour and maintain existing lower elevation features in active channel, but larger magnitude floods are needed to actually carve and create new secondary features, particularly along floodplain swales and older higher elevation surfaces in the active channel.

Depositional features, including gravel bars and spawning gravels, historically were most abundant along the lower McKenzie River basin. Presently, the formation of gravel bars is limited by multiple factors including (1) sediment supply, resulting from naturally low sediment yield rates from the upper basin, and exacerbated by trapping of bed-material by dams, (2) high velocity transport capacity capable of transporting available gravel and cobbles to lower reaches rather than creating depositional zones where bars can form, (3) limited recruitment by bank erosion because of reduced flows and bank stabilization, and (4) vegetation colonization and stabilization of formerly active bar surfaces, resulting from reduction in peak flows. Previous studies have indicated that decreases in spawning habitat on the McKenzie River partly may be a result of bed coarsening, which can be exacerbated by sediment trapping behind dams; however, further studies are needed to determine relations between bed substrate, spawning habitat, and sediment availability. 
Streamflow plays an important role in determining the availability of gravel bars and other depositional features because it not only determines transport capacity, but also drives bank erosion and disrupts vegetation on gravel bars, hence, allowing for remobilization of gravels stored in bar and floodplain deposits. It can be hypothesized that bankfull streamflow events may reduce vegetation on low bar surfaces and may remobilize existing bare bars, but small to large floods are needed to substantially rework the heavily vegetated (but historically active) gravel bars. Furthermore, small to large flood events (2- to 10-year recurrence interval) will also have a greater capacity to trigger bank erosion, particularly along unrevetted areas of the lower McKenzie River basin alluvial reaches. This could release gravels and large wood that facilitate the creation of new bars and spawning habitat. In order to further refine these relationships, additional studies are needed to quantify sediment transport capacity and bank erosion under a range of flow conditions, and to also develop sediment budgets for different parts of the McKenzie River basin.

Alluvial reaches along the lower McKenzie River basin historically supported broad, forested floodplains, whereas the floodplains along the middle and upper McKenzie River basins are typically narrow and confined by steep valley walls. Reduction of peak streamflow has resulted in fewer overbank flood events that carve and maintain floodplain channels, which not only provide refuge during high streamflows, but also contribute to vegetative patch heterogeneity. Furthermore, flow reduction, in combination with bank stabilization and reductions in sediment supply, has decreased the frequency of "floodplain recycling events," which occur when erosion of floodplain surfaces mobilizes sediment and large wood that are deposited elsewhere and eventually evolve into future floodplain surfaces. Therefore, the discharge events that likely are to have the greatest effect on floodplain formation are overbank events (such as small to large floods) when floodplain channels can be scoured and bank erosion can more substantially modify floodplain margins. However, at least one area along the lower McKenzie River basin seems to be experiencing incision, and if incision is widespread, it could negatively influence floodplain habitat by reducing connectivity between the channel and its adjacent floodplains. Additional studies are needed to evaluate the magnitude and extent of incision and to determine whether environmental flow releases would exacerbate bed lowering.

Nine exemplar aquatic and terrestrial species used in the study included spring Chinook salmon, bull trout, Pacific and brook lamprey, Oregon chub, red-legged frog, western pond turtle, white alder, and cottonwood. These species were combined into three groups based on the primary habitats they use: mainstem aquatic species (Chinook salmon, bull trout, and Pacific and brook lamprey), offchannel aquatic species (Oregon chub, red-legged frog, western pond turtle), and floodplain and riparian vegetation (white alder and black cottonwood).
Spring Chinook salmon, bull trout, and brook and Pacific lamprey are species native to the McKenzie River basin that require a diversity of instream and offchannel habitats. In addition, they are all coldwater species and spawn in similar flowing-water habitats. These four species use or require habitat features that are created and maintained primarily by the interaction of small to large floods with local landscape features. Habitat features of particular importance and common to these species include large, deep mainstem pools, secondary channels, and well sorted spawning gravels with interstitial streamflow. All four species also are sensitive to the seasonal timing of streamflows and water temperatures and thus are affected by alterations in streamflow and temperature associated with dam operations.

The Oregon chub, western pond turtle, and red-legged frog are native species that require a diversity of offchannel habitats, including mature side channels, sloughs, oxbow lakes, ponds, and wetlands. These kinds of habitats are created and maintained by the interaction of high streamflow events such as small to large floods with local landscape features. In addition, high streamflows in winter and spring are essential for the dispersal of seed and vegetative propagules of riparian and floodplain trees and shrubs. High streamflows also generate and maintain areas of bare soils necessary for germination, and their timing and ramping rates during reservoir releases are critical for the maintenance of proper water tables necessary for growth and survival of riparian vegetation.

The changes caused by the dams to natural streamflows affect all these and other species in complex ways; nevertheless, a few commonalities can be stated. The reduction in small to large floods in the McKenzie River basin, along with bank stabilization, likely are primary factors involved in reducing channel complexity, which has been evidenced by reductions in mainstem spawning sites, deep complex pools, and secondary channel features. Reductions in these key habitat types have been implicated as a key factor in the population declines of all nine exemplar aquatic and terrestrial species. The dams also have had direct effects by blocking access to habitat, changing the amount and timing of important transient habitats, and altering water temperature and its seasonal timing (important as migratory, growth, and life history cues), as well as affecting other factors important to the exemplar species outlined in this report.

\section{Acknowledgments}

The authors thank Andrew Talabare, Eugene Water \& Electric Board; Greg Taylor, U.S. Army Corps of Engineers; Leslie Bach, The Nature Conservancy, Portland, Oregon; Karl Morgenstern, Eugene Water \& Electric Board, Eugene, Oregon; Hilaire Peck, U.S. Army Corps of Engineers, Portland, Oregon; Sherri Johnson, U.S. Forest Service, Pacific Northwest Research Station, Corvallis, Oregon; and Chris Konrad, USGS, Seattle, Washington for their assistance in this report. 


\section{References Cited}

Abbe, T.B. and Montgomery, D.R., 2003, Patterns and processes of wood debris accumulation in the Queets river basin, Washington: Geomorphology, v. 51, p. 81-107.

Acreman, M., and Dunbar, M.J., 2004, Defining environmental flow requirements-A review: Hydrology and Earth System Sciences, v. 8, no. 5, p. 861-876.

Allan, J.D., 1995, Stream ecology-Structure and function of running waters: Chapman and Hall, New York, 388 p.

H.J. Andrews Experimental Forest, 2009, Publications data base: H.J. Andrews Experimental Forest LTER, last accessed June 8, 2009, at http://andrewsforest.oregonstate. edu/pubs.cfm?topnav=11

Beechie, T., Buhle, E., Ruckelshaus, M., Fullerton, A., and Holsinger, L., 2006, Hydrologic regime and the conservation of salmon life history diversity: Biological Conservation, v. 130 , p. 560-572.

Bjornn, T.C. and Reiser, D.W., 1991, Habitat requirements of salmonids in streams, in Meehan, W.R., Influences of forest and rangeland management on salmonid fishes and their habitats: American Fisheries Society Special Publication, v. 19 , p. $83-138$.

Bowman, D., 1977, Stepped-bed morphology in arid gravely channels: Geological Society of America Bulletin, v. 83, p. 291-298.

Buffington, J.M., Lisle, T.E., Woodsmith, R.D., and Hilton, S., 2002, Controls on the size and occurrence of pools in coarse-grained forest rivers: River Research and Applications, v. 18, no. 6, 507-531.

Bureau of Land Management, 1998a, Vida/McKenzie Watershed-McKenzie Resource Area: U.S. Department of the Interior, Bureau of Land Management, Eugene District, Oregon, [variously paged].

Bureau of Land Management, 1998b, Bear/Marten WatershedMcKenzie Resource Area: U.S. Department of the Interior, Bureau of Land Management, Eugene District, Oregon, [variously paged].

Church, M., 1983, Pattern of instability in a wandering gravel bed channel, in Collinson, J.D. and Lewis, J., eds., Modern and Ancient Fluvial Systems: International Association of Sedimentologists Special Publication, v. 6, p. 169-180.

Dietrich, W.E., Kirchner, J.W., Ikeda, H., and Iseya, F., 1989, Sediment supply and the development of the coarse surface later in gravel-bedded rivers: Nature, v. 340, no. 6230, p. 215-217.
Dykaar, B.B. and Wigington, P.J., Jr., 2000, Floodplain formation and cottonwood colonization patterns on the Willamette River, Oregon, USA: Environmental Management, v. 25, p. 87-104.

Ecosystems Northwest, 1998, Quartz Creek and minor watershed analysis: Corvallis, Oregon, [variously paged].

Emmett, W.W., Leopold, L.B., and Myrick, R.M., 1985, Some characteristics of fluvial processes in rivers, in Proceedings of the advanced seminar on sedimentation, Denver, Colorado, August 15-19, 1983, U.S. Geological Survey, Open File Report OF 85-0098, 66 p.

Emmet, W.W. and Wolman, M.G., 2001, Effective discharge and gravel-bed rivers: Earth Surface Processes and Landforms, v. 26, p. 1369-1580.

Eugene Water and Electric Board, 2008a, EWEB: 2007 Facts and Figures: Eugene, Oreg., Eugene Water and Electric Board, 30 p., accessed May 22, 2009, at http://www.eweb. org/public/documents/ewebFacts.pdf

Eugene Water and Electric Board, 2008b, Carmen-Smith Hydroelectric Project: Eugene, Oreg., Eugene Water and Electric Board, accessed May 22, 2009, at http://www.eweb. org/public/documents/publications/carmensmith_brochure. pdf

Everest, F.H., Beschta, R.L., Scrivener, J.C., Koski, K.V., Sedell, J.R., and Cederholm, C.J., 1987, Fine sediment and salmonid production: a paradox, in Salo, E.O. and Cundy, T.W., eds., Streamside management: forestry and fishery interactions: University of Washington Institute of Forest Resources Contribution 57, p. 98-142.

Fernald, A.G., Wigington, P.J. Jr., and Landers, D.H., 2001, Transient storage and hyporheic flow along the Willamette River, Oregon: model estimates and field measurements: Water Resources Research, v. 37, no. 6, p. 1681-1694.

Fetherston, K.L., Naiman, R.J., and Bilby, R.E., 1995, Large woody debris, physical process, and riparian forest succession in montane river networks of the Pacific Northwest: Geomorphology, v. 13, p. 133-144.

Fierke, M.K. and Kauffman, J.B., 2005, Structural development and biomass of black cottonwood-dominated gallery forests along a successional gradient, Willamette River, Oregon: Oregon Forest Ecology Management, v. 215, p. 149-162.

Fierke, M.K. and Kauffman, J.B., 2006, Riverscape patterns in riparian plant diversity along a black cottonwood successional gradient, Willamette River, Oregon: Oregon Plant Ecology, v. 185, p. 85-95. 
Grant, G.E., Crozier, M.J., and Swanson, F.J., 1984, An approach to evaluating off-site effects of timber harvest activities on channel morphology, in Proceedings of the Symposium on the Effects of Forest and Land Use on Erosion and Slope Stability, Environmental and Policy Institute: East-West Center, University of Hawaii, Honolulu, p. 177-186.

Grant, G. E. and Swanson, F.J. 1995. Morphology and processes of valley floors in mountain streams, western Cascades, Oregon. In: Costa, J.E., Miller, A.J., Potter, K.W., and Wilcock, P.R (eds.), Natural and Anthropogenic Influences in Fluvial Geomorphology: the Wolman Volume, Geophysical Monograph No. 89, American Geophysical Union, Washington, D.C., p. 83-101.

Gregory, S., Ashkenas, L., Haggerty, P., Oetter, D., Wildman, K., Hulse, D., Branscomb, A. and Van Sickle, J., 2002 b. Riparian vegetation, in Hulse, D., Gregory, S., and Baker, J., eds., Willamette River basin atlas: Oregon State University Press, Corvallis, Oregon, p. 4033. Report and datasets available online at http://oregonstate.edu/dept/pnw-erc/

Gregory, S., Ashkenas, L., and Nygaard, C., 2007a, Summary report to assist development of ecosystem flow recommendations for the Middle Fork and Coast Fork of the Willamette River, Oregon: Institute for Water and Watersheds, Oregon State University, Corvallis, Oregon, 237 p.

Gregory, S., Ashkenas, L., and Nygaard, C., 2007b, Summary report-Environmental flows workshop for the Middle Fork and Coast Fork of the Willamette River, Oregon: Institute for Water and Watersheds, Oregon State University, Corvallis, Oregon, 34 p.

Gregory, S., Ashkenas, L., Oetter, D., Wildman, R., Minear P., Jett, S. and Wildman, K., 2002a, Revetments, chapter in Hulse, D., Gregory, S., and Baker, J., eds., Willamette River basin Atlas: Oregon State University Press, Corvallis, Oregon, p 32-33. Report and datasets available online at: http://oregonstate.edu/dept/pnw-erc/

Gregory, S.V., Swanson, F.J., McKee, W.A., and Cummins, K.W., 1991, An ecosystem perspective of riparian zones: Bioscience, v. 41, p. 540-551.

Gutowsky, S., 2000, Riparian cover changes associated with flow regulation and bank stabilization along the upper Willamette River in Oregon between 1939-1996: Corvallis, Oregon, Oregon State University, M.S. thesis, 92 p.

Hansen, R.P., 1988, The effects of two multipurpose reservoirs on the water temperature of the McKenzie River, Oregon: U.S. Geological Survey Water Resources Investigations Report 87-4175, 34 p.
Hickey, J.J., 1969, Variations in low-water streambed elevations at selected stream-gaging stations in northwestern California: U.S. Geological Survey Water Supply Paper 1879-E, 33 p.

Hupp, C.R. and Osterkamp, W.R., 1985, Bottomland vegetation distribution along Passage Creek, Virginia, in relation to fluvial landforms: Ecology, v. 66, p. 670-681.

Ingrebritsen, S.E., Mariner, R.H., and Sherrod, D.R., 1994, Hydrothermal systems of the Cascade Range, North-Central Oregon: U.S. Geological Survey Professional Paper 1044-L, $85 \mathrm{p}$.

Interagency Advisory Committee on Water Data, 1981, Guidelines for determining flood flow frequency-Bulletin 17B of the Hydrology Subcommittee: U.S. Geological Survey, last accessed December 3, 2009, at http://water. usgs.gov/osw/bulletin $17 \mathrm{~b} / \mathrm{dl}$ flow.pdf.

Jackson, W.L. and Beshta, R.L., 1982, A model of two-phase bedload transport in an Oregon Coast Range stream: Earth Surface Processes and Landforms, v. 7, p. 517-527.

Jefferson, A., Grant, G.E., and Rose, T., 2006, Influence of volcanic history on groundwater patterns on the west slope of the Oregon High Cascades: Water Resources Research, v. 42, 15 p., W12411, doi: 10.1029/2005WR004812.

Johnson, C.W., and Buffler, S., 2008, Riparian buffer design guidelines for water quality and wildlife habitat functions on agricultural landscapes in the Intermountain West: General Technical Report RMRS-GTR-203, U.S. Department of Agriculture, Forest Service, Rocky Mountain Research Station, Fort Collins, Colorado, 53 p.

Keller, E.A., 1971, Areal sorting of bed load material-The hypothesis of velocity reversal: Geological Society of America Bulletin, v. 82, 753-756.

Kelsey, H. M., 1980, A sediment budget and analysis of geomorphic process in the Van Duzen River basin, north coastal California, 1941-1975: Geological Society of America Bulletin, v. 91, no. 4, p. 1119-1216.

Kiesecker, J.M. and Blaustein, A.R., 1998, Effects of introduced bullfrogs and smallmouth bass on microhabitat use, growth, and survival of native red-legged frogs (Rana aurora): Conservation Biology, v. 12, p. 776-787.

Klingeman, P.C., 1973, Indications of Streambed Degradation in the Willamette Valley: WRRI-21, Water Resources Research Institute Report WRRI-21, Corvallis, Department of Civil Engineering, Oregon State University, 99 p.

Kondolf, G.M., 1997, Hungry Water: Effects of Dams and Gravel mining on River Channels: Environmental Management, v. 21, no. 4, p. 533-551. 
Kondolf, G.M. and Wilcock, P.R., 1996, The flushing flow problem-Defining and evaluating objectives: Water Resources Research, v. 32, no. 8, p. 2589-2599.

Kondolf, G.M. and Wolman, M.G., 1993, The sizes of salmonid spawning gravels: Water Resources Research, v. 29 , no. 7 , p. $2275-2285$.

Lignon, F., 1991, The fluvial geomorphology of the Lower McKenzie River: Prepared by EA Engineering, Science, and Technology, Lafayette California for Eugene Water \& Electric Board, Eugene, Oregon, 51 p.

Lignon, F., Dietrich, W., and Trush, W., 1995, Downstream ecological effects of dams, a geomorphic perspective: Bioscience, v. 45, p. 183-192.

Lisle, T. E., 1981, Recovery of aggraded stream channels at gauging stations in northern California and southern Oregon, in Davies, T.R.H. and Pearce, A.J., eds., Erosion and Sediment Transport in Pacific Rim Steeplands: IAHS AISH Publication 132, p. 189-211.

Lisle, T.E., 1982, Effects of aggradation and degradation on riffle-pool morphology in natural gravel channels, Northwestern California: Water Resources Research, v. 18, no. 6, p. 1643-1651.

Manga M., 1997, A model for discharge in spring-dominated streams and implications for the transmissivity and recharge of Quaternary volcanics in the Oregon Cascades, Water Resources Research, v. 33, no. 8, p. 1813-1822.

Meehan, W.R., 1991, Influences of forest and rangeland management on salmonid fishes and their habitats: American Fisheries Special Publication, v. 19, 750 p.

Megahan, W., 1982, Channel sediment storage behind obstructions in forested drainage basins draining the granitic bedrock of the Idaho batholith, in Swanson, F.J., Janda, R.J., Dunne, T., and Swanston, D.N., eds., Sediment budgets and routing in forested drainage basins: USDA Forest Service, Pacific Northwest Forest and Range Experimental Station, General Technical Report PNW-141, p.114-121.

Minear, Paula J., 1994, Historical Change in Channel Form and Riparian Vegetation of the McKenzie River, Oregon: Corvallis, Oregon, Oregon State University, M.S. thesis, 175 p., 24 figs.

Minshall, G.W., 1984, Aquatic insect-substrate relationships, in Resh, V.H. and Rosenberg, D.M., eds., The ecology of aquatic insects: Praeger Publishers, New York, p. 658-400.

Montgomery, D.R., Abbe, T.B., Buffington, J.M., Peterson, N.P., Schmidt, K.M., and Stock, J.D., 1996, Distribution of bedrock and alluvial channels in forested mountain drainage basins: Nature, v. 381, p. 587-589
Montgomery, D.R. and Buffington, J.M., 1997, Channelreach morphology in mountain drainage basins: Geological Society of America Bulletin, v. 109, no. 5, p. 596-611.

Montgomery, D.R., Buffington, J.M., Smith, R.D., Schmidt, K.M., and Pess, G., 1995, Pool spacing in forest channels: Water Resources Research, v. 31, no. 4, p. 1097-1105.

Murphy, M.L. and Meehan, W.R., 1991, Stream Ecosystems, in Meehan, W.R., ed., Influences of forest and rangeland management on salmonid fishes and their habitats, : American Fisheries Society Special Publication v. 19, p. 17- 46 .

Myers, J., Busack, C., Rawding, D., Marshall, A., Teel, D., Van Doornik, D.M. and Maher, M.T., 2006, Historical population structure of Pacific salmonids in the Willamette River and Lower Columbia River basins: U.S. Department of Commerce, NOAA Technical memo NMFS-NWFSC73, $311 \mathrm{p}$.

Nadler, C.T. and Schumm, S.A., 1981, Metamorphosis of the South Platte and Arkansas Rivers, eastern Colorado: Physical Geography, v. 2, no. 2, p. 95-115.

Nanson, G.C. and Croke, J.C., 1992, A genetic classification of floodplains: Geomorphology, v. 4, p. 459-486.

National Marine Fisheries Service, 2008a, Endangered Species Act Status of West Coast Salmon and Steelhead: NOAA National Marine Fisheries Service, Northwest Region, Seattle, Washington, accessed October 7, 2008, http://www. nwr.noaa.gov/ESA-Salmon-Listings/upload/snapshot0208. $\underline{\text { pdf }}$

National Marine Fisheries Service, 2008b, Endangered Species Act Section 7(a)(2) Consultation biological opinion and Magnuson-Stevens fishery conservation and management act essential fish habitat consultation: NOAA National Marine Fisheries Service, Northwest Region, Seattle, Washington, NOAA Fisheries Log Number: FINWR12000/02117, [various pagination], last accessed May 22, 2009, at http://www.nwr.noaa.gov/SalmonHydropower/Willamette-Basin/Willamette-BO.cfm

National Weather Service, 2009, Northwest river forecast center: National Oceanic and Atmospheric Administration, National Weather Service, last accessed July 3, 2009, at http://www.nwrfc.noaa.gov/river/station/flowplot/flowplot. cgi?VIDO3.

The Nature Conservancy, 2007, Indicators of hydrologic alteration-Version 7 User's manual: The Nature Conservancy, 75 p., last accessed November 17, 2008, http://www.nature.org/initiatives/freshwater/ conservationtools/art17004.html. 
The Nature Conservancy, 2009a, Savannah River Southeastern United States: last accessed August 3, 2009, at http://www. nature.org/initiatives/freshwater/files/savannah case study v1 new logo.pdf

The Nature Conservancy, 2009b, Green River, Southeastern United States: last accessed August 3, 2009, at http://www. nature.org/initiatives/freshwater/files/green_river_case study final high res new logo.pdf

The Nature Conservancy, 2009c, Roanoke River, North Carolina: last accessed August 3, 2009, http://www.nature. org/initiatives/freshwater/work/roanokeriver.html

The Nature Conservancy, 2009d, Willamette River, Pacific Northwest, United States, last accessed August 3, 2009, http://www.nature.org/initiatives/freshwater/files/ willamette case study final low res new logo.pdf

The Nature Conservancy, 2009e, The sustainable rivers project: last accessed July 28, 2009, at http://www.nature. org/initiatives/freshwater/partnership.

Northwest Power and Conservation Council, 2004, Draft Willamette Subbasin Plan: Prepared by Primozick, D. and Bastasch, R., eds., Willamette Restoration Initiative, Northwest Power and Conservation Council, Portland, Oregon, 748 p., accessed June 3, 2009, http://www. nwcouncil.org/fw/subbasinplanning/willamette/plan/

O’Connor, J.E., Jones, M.A., and Haluska, T.L., 2003, Flood plain and channel dynamics of the Quinalt and Queets Rivers, Washington, USA: Geomorphology, v. 51, p. 31-59.

O’Connor, J.E., Sarna-Wojcicki, A., Wozniak, K.E., Polette, D.J., and Fleck, R.J., 2001, Origin, extent, and thickness of Quaternary geologic units in Willamette Valley, Oregon: U.S. Geological Survey Professional Paper 1620, 52 p. Dataset available online at http://or.water.usgs.gov/pubs dir/Online/Cd/WRIR99-4036/GIS FILES/will_geol.html, last accessed July 29, 2009.

O’Connor, J.E., Webb, R.H., and Baker, V.R., 1986, Paleohydrology of pool-and-riffle pattern development: Boulder Creek, Utah: Geological Society of America Bulletin, v. 97, p. 410-420.

Oregon Department of Environmental Quality, 2006, Willamette basin total maximum daily load order memorandum: Oregon Department of Environmental Quality, last accessed October 7, 2008, at http://www. deq.state.or.us/wq/tmdls/docs/willamettebasin/willamette/ ordermemo.pdf

Oregon Department of Environmental Quality, 2009, Water Quality Assessment: last accessed December 4, 2009, at http://www.deq.state.or.us/wq/assessment/assessment.htm.
Oregon State University, 2009, Oregon imagery explorer: last accessed July 29, 2009, at http://oregonexplorer.info/ imagery/

University of Oregon, 2009, FEMA Q3 flood data-Oregon counties: last accessed July 9, 2010, at http://libweb. uoregon.edu/map/gis data/fema.html.

Pacific Northwest Ecosystem Research Consortium (PNWERC), 2002, Willamette River basin planning atlas: trajectories of environmental and ecological change in Hulse, D., Gregory, S., Baker, J., eds., Oregon State University Press, Corvallis, last accessed August 5, 2009, at: http://www.fsl.orst.edu/pnwerc/wrb/Atlas_web_ compressed/PDFtoc.html

Poff, N.L., Allan, J.D., Bain, M.B., Karr, J.R., Prestegaard, K.L., Richter, B.D., Sparks, R.E., and Stromberg, J.C., 1997, The Natural Flow Regime: BioScience, v. 47, no. 11, p. 769-784.

Richter, B.D., Warner, A.T., Meyer, J.L., and Lutz, K., 2006, A collaborative and adaptive process for developing environmental flow recommendations: River Research and Applications, v. 22, p. 297-318, DOI: 10.1002/rra.892.

Rounds, S.A., 2007, Temperature effects of point sources, riparian shading, and dam operations on the Willamette River, Oregon: U.S. Geological Survey Scientific Investigations Report 2007-5185, 34 p.

Roy, A.H., Rosemond, A.D., Leigh, D.S., Paul, M.J., Wallace, J. B., 2003, Habitat-specific responses of stream insects to land cover disturbance: biological consequences and monitoring implications: Journal of the North American Benthological Society, v. 22, no. 2, p. 292-307.

Sedell, J.R., and Froggatt, J.L., 1984, Importance of streamside forests to large rivers: the isolation of the Willamette River, Oregon, USA, from its floodplain by snagging and streamside forest removal: Verhandlungen der Internationale Vereinigung fur Theoretische und Angewandte Limnologie, v. 22, p 1828-1834.

Sedell, J.R., McIntosh, B.A., and Minear, P.J., 1991, Evaluation of past and present stream habitat conditions, Report for the Army Corps of Engineers McKenzie River Temperature Control Feasibility Study: U.S. Forest Service Pacific Northwest Research Station, Corvallis Oregon, 13 p.

Shafroth, P.B. and Beauchamp, V.B., 2006, Defining ecosystem flow requirements for the Bill Williams River, Arizona: U.S. Geological Survey Open-File Report 20061314, 135 p. 
Sherrod, D.R. and Smith, J. G., 2000, Geologic map of upper Eocene to Holocene volcanic and related rocks of the Cascade Range, Oregon: U.S. Geological Survey Geologic Investigations Series Map I-2569, 2 sheets, scale 1:500,000. http://pubs.usgs.gov/imap/i-2569/.

Stearns, H.T., 1928, Geology and water resources of the Upper McKenzie Valley, Oregon in Grover, Nathan, C., ed., Contributions to the hydrology of the United States: U.S.

Geological Survey Water Supply Paper 597-D, p. 171-188.

Stillwater Sciences, 2006a, Hydrologic regimes at the Carmen-Smith Hydroelectric Project, upper McKenzie River basin, Oregon, Final report: prepared by Stillwater Sciences, Arcata, California for Eugene Water \& Electric Board, Eugene, Oregon, [various pagination].

Stillwater Sciences, 2006b, Fluvial Geomorphic Processes and Channel Morphology at the Carmen-Smith Hydroelectric Project, upper McKenzie River basin, Oregon, Final Report: prepared by Stillwater Sciences, Arcata, California for Eugene Water \& Electric Board, Eugene, Oregon, [various pagination].

Sullivan, K., Lisle, T.E., Dolloff, C.A., Grant, G.E., and Reid, L.M., 1987, Stream channels: the link between forests and fishes, in Salo, E.O. and Cundy, T.W., eds., Streamside Management: forestry and fishery interations: Institute of Forest Resources, University of Washington, Seattle, WA, Contribution 57, p. 39-97.

Tague, C., Farrell, M., Grant, G., Lewis, S., and Rey, S., 2007, Hydrogeologic controls on summer stream temperatures in the McKenzie River basin, Oregon: Hydrological Processes, v. 21 , p. $3288-3300$.

Tague, C. and Grant, G., 2004, A geological framework for interpreting the low flow regimes of Cascade streams, Willamette River basin, Oregon: Water Resources Research, v. 40, 9 p., W04303. DOI: 10Đ1029/2003WR002629.

Tal, M., Gran, K., Murray, A.B., Paola, C., and Hicks, D.M., 2004, Riparian vegetation as a primary control on channel characteristics in multi-thread rivers, in Bennett, S.J. and Simon, A., eds., Riparian Vegetation and Fluvial Geomorphology: American Geophysical Union, Washington, D.C., p. 43-58.

Tappel, P.D. and Bjorn, T.C., 1983, A new method of relating size of spawning gravel to salmonid embryo survival: North American Journal of Fisheries Management, v. 3, p. 123-135.
Taylor, Greg, 2003, Bull trout population and habitat surveys in the Middle Fork Willamette and McKenzie Rivers, Project No. 1994-05300: BPA Report DOE/ BP-00004093-2, 16 p., last accessed July 28, 2009, at http://pisces.bpa.gov/release/documents/documentviewer. aspx?doc $=00004093-2$.

Tharme, R.E., 2003, A global perspective on environmental flow assessment: emerging trends in the development and application of environmental flow methodologies for rivers: River Research and Applications, v. 19, p. 397-441, DOI: 10.1002/rra.736.

Thompson, D.M., Wohl, E.E. and Jarrett, R.D., 1999, Velocity reversals and sediment sorting in pools and riffles controlled by channel constrictions: Geomorphology, v. 27, p. 229241.

U.S. Army Corps of Engineers (USACE), 2000, Biological assessment of the effects of the Willamette River basin flood control project on species listed under the Endangered Species Act: prepared by Portland District, U.S. Army Corps of Engineers for the National Marine Fisheries Service and U.S. Fish and Wildlife Service, pages\#.

U.S. Army Corps of Engineers (USACE), 2007, Supplemental biological assessment of the effects of the Willamette River basin flood control project on species listed under the Endangered Species Act: U. S. Army Corps of Engineers, Portland District, Submitted to National Marine Fisheries Service and U.S. Fish and Wildlife Service, [variously paged], accessed June 3, 2009, http://www.nwp.usace.army. mil/pm/e/en plan ba.asp

U.S. Army Corps of Engineers (USACE), 2009a, Cougar Dam and Lake: last accessed on October 12, 2009, at http://www. nwd-wc.usace.army.mil/report/cgr.htm

U.S. Army Corps of Engineers (USACE), 2009b, Blue River Dam and Lake: last accessed on October 12, 2009, at http:// www.nwd-wc.usace.army.mil/report/blu.htm

U.S. Forest Service, 1994, South Fork McKenzie Watershed Analysis: Blue River Ranger District, Willamette National Forest, Blue River, Oregon, [variously paged].

U.S. Forest Service, 1995, Upper McKenzie Watershed Analysis: U.S. Department of Agriculture, Forest Service, [variously paged].

U.S. Forest Service, 1996, Blue River Watershed Analysis: U.S. Department of Agriculture, Forest Service, [variously paged]. 
U.S. Forest Service, 1997, Horse Creek Watershed Analysis, U.S. Department of Agriculture, Forest Service, [variously paged].

U.S. Geological Survey, 2009, Water resources of the United States - 2008 Annual data report, Documentation, Explanation of water-quality records: last accessed July 29, 2009, at http://wdr.water.usgs.gov/wy2008/documentation. html\#qw

Wallick, J.R., Grant, G.E., Lancaster, S.T., Bolte, J.P., and Denlinger, R.P., 2007, Patterns and controls on historical channel change in the Willamette River, Oregon, in Gupta, A.V., ed., Large Rivers: Geomorphology and Management, John Wiley and Sons, Chichester, p. 491-516.

Wallick, J.R., Lancaster, S.T., and Bolte, J.P., 2006, Determination of Bank Erodibility for natural and anthropogenic bank materials using a model of lateral migration and observed erosion along the Willamette River, Oregon, USA: River Research and Applications, v. 22, p. 631-649.

Ward, J.V., and Stanford, J.A., 1983, The serial discontinuity concept of lotic ecosystems, in Fontaine III, D.T.I., and Bartell, S.M., eds., Dynamics of lotic ecosystems: Ann Arbor Science Publishers, Ann Arbor, p. 29-42.
Wesche, T.A., 1991, Flushing streamflow requirements of mountain stream channels: Pullman, Washington, Washington State University, Ph.D. dissertation, p. \#\#.

Weyerhaeuser Company, 1994, Lower McKenzie River, South Side watershed analysis: Springfield, Oregon, [variously paged].

Weyerhaeuser Company, 1995, Lower McKenzie, North Side Watershed analysis: Springfield, Oregon, [variously paged].

Williams, G.P. and Wolman, M.G., 1984, Downstream effects of dams on alluvial rivers: U.S. Geological Survey Professional Paper 1286, 83 p.

Wohl, E.E., Vincent, K.R., and Merrits, D.J., 1993, Pool and riffle characteristics in relation to channel gradient: Geomorphology, v. 6, p. 99-110.

Wolman, M.G. and Gerson, R., 1978, Relative scales of time and effectiveness of climate in watershed geomorphology, Earth Surface Processes, v. 3, p. 189-208.

Wolman, M.G. and Miller, J.P., 1960, Magnitude and frequency of forces in geomorphic processes: Journal of Geology v. 68, pp. 54-74. 
This page intentionally left blank. 


\section{Appendix A. U.S. Geological Survey Streamflow Data Time-Series Extensions}

The streamflow data time-series extensions are included in a set of Microsoft ${ }^{\circledR}$ Excel files, which can be downloaded from http://pubs.usgs.gov/sir/2010/5016.

In the directory, there are 12 Excel files that pertain to the study Reaches 1 through 12 (For example, Reach1.xls). In each Excel file, there is a "Read Me" worksheet that explains how the streamflow time series for the reach was extended. 


\section{Appendix B. U.S. Army Corp of Engineers Computed Unregulated Streamflow Data Time Series}

Unregulated streamflow data time series for the South Fork McKenzie River (14159500), Blue River (14162200), and McKenzie River near Vida (14162500) were computed using the equations below developed by the U.S. Army Corps Engineers. The streamflow data time series for the three sites are included in the Reach3.xls, Reach5.xls, and Reach7.xls Excel files described in appendix A.

\section{South Fork McKenzie River (14159500)}

Water year 1936-1947

Streamflow calculated by correlation between stations 14159500 and $14147500 \mathrm{y}=82.31+0.97399 \mathrm{x}, \mathrm{R}=0.97898$

Water year 1948-1962

Straight streamflow from station 14159500 , no DA factor needed

Water year 1963-1987

Streamflow calculated from station 14159200 , DA factor $=1.294$

Water years 1988-1994

Same as first time period, correlation, between stations 14159500 and 14147500

Water years $1995-2000$

Calculate station $14159200=0.320 \mathrm{a}+91.1$, where $\mathrm{a}=14148000-14145500$

Inflow $=14159200 * 1.294$

Water years 2001-2004

Inflow=station $14159200 * 1.294$

\section{Blue River (14162200):}

Water years 1936-1964

Flow from station $14162000, \mathrm{DA}$ factor $=1.164$

Water years $1965-2003$

Flow from stations 14161100 and 14161500

DA factor of 1.38 applied to station 14161100 only, then added to straight values of 14161500

Water year 2004

Calculate station $14161100=($ station $14161500 * 2.136)-5.4$

Inflow $=$ station $14161100 * 1.38+$ station 14161500

\section{McKenzie River near Vida (14162500)}

/MCKENZIE/VIDA/FLOW-LOC INC//1DAY/ HEC5 COMPUTED/

- Computed using Blue River and Cougar Outflows

- Blue River: water years 1936-1966: Used computed Blue River Inflows as Outflows (dam was not constructed yet)

- Water years 1967-2008, station 14162200

- Cougar: water years 1936-1947: Used computed Cougar Inflows as Outflows (dam was not constructed yet)

- Water years 1948-2004, station 14159500

- Routing factors for both: $0.84,0.16$ 


\section{Appendix C. Indicators of Hydrologic Alteration Results}

The output results from the Indicators of Hydrologic Alteration software are included in a set of Microsoft $^{\odot}$ Excel files, which can be downloaded from http://pubs.usgs.gov/sir/2010/5016.

In the directory there are 12 Excel files, which pertain to the study Reaches 1-12 (for example, R1obs.xls).

Statistical Testing:

The Indicators of Hydrologic Alteration software includes a "significance count" as a means of testing if the difference between a pre- and post-impact period metric is significant. The significance count value can be interpreted similarly to a p-value. A description of the test from the software manual (p. 47) is shown below:

"Columns 7 and 8 calculate a "significance count" for the deviation values. To calculate this, the software program randomly shuffles all years of input data and recalculates (fictitious) pre- and post-impact medians and CDs 1000 times. The significance count is the fraction of trials for which the deviation values for the medians or CDs were greater than for the real case. So a low significance count (minimum value is 0 ) means that the difference between the pre- and post-impact periods is highly significant, and a high significance count (maximum value is 1) means that there is little difference between the pre- and post-impact periods. The significance count can be interpreted similarly to a p-value in parametric statistics.”

"It is important to understand that in some infrequent situations this algorithm may generate very low significance counts when there is very little apparent difference between the pre- and post-impact periods. This can occur when the deviation factor between the pre- and post-impact periods is zero or very small, and the overall distribution contains a large number of values right at or very near the center of the distribution. In this situation a low significance count actually means that the lack of difference between the two periods is highly significant, in a statistical sense, because randomly rearranging the data rarely yield a larger deviation factor than the original data.”

"It also is important to understand that significance counts may differ slightly each time the IHA is run for the same dataset, since a new set of randomized cases is generated each time." 
This page intentionally left blank. 
Publishing support provided by the U.S. Geological Survey

Publishing Network, Tacoma Publishing Service Center

For more information concerning the research in this report, contact the Director, Oregon Water Science Center

U.S. Geological Survey

2130 SW 5th Avenue

Portland, Oregon 97201

http://or.water.usgs.gov 
읏

홀

के

곳 